

\section{Commodifying Violence in Literature and on Screen}

This book traverses the cultural landscape of Colombia through in-depth analyses of displacement, local and global cultures, human rights abuses, and literary and media production. Through an exploration of the cultural processes that perpetuate the "darker side" of Latin America for global consumption, it investigates the "condition" that has led writers, filmmakers, and artists to embrace (purposefully or not) the incessant violence in Colombian society as the object of their own creative endeavors. In this examination of mass-marketed cultural products such as narcostories, captivity memoirs, gritty travel narratives, and films, HerreroOlaizola seeks to offer a hemispheric approach to the role played by Colombia in cultural production across the continent where the illicit drug trade has made significant inroads. To this end, he identifies the "Colombian condition" within the parameters of the global economy while concentrating on the commodification of Latin America's violence for cultural consumption.

Alejandro Herrero-Olaizola is Arthur F. Thurnau Professor of Spanish and Latin American Studies at the University of Michigan, Ann Arbor. He is the author of The Censorship Files: Latin American Writers and Franco's Spain (2007) and Narrativas híbridas: parodia y posmodernismo en la ficción contemporánea de las Américas (2000), and co-editor of Market Matters (Arizona Journal of Hispanic Cultural Studies), Teaching the Latin American Boom (2015), and Territories of Conflict: Traversing Colombia Through Cultural Studies (2017). His articles have appeared in Symposium, Revista Crítica de Literatura Latinoamericana, Hispanófila, $M L N$, and Hispanic Review. Currently, he is the Editor of Revista de Estudios Colombianos. His research has been supported by the NEH, ACLS, and Fulbright fellowships. 


\section{Routledge Interdisciplinary Perspectives on Literature}

136 Reconstructing the Social Sciences and Humanities Antenor Firmin, Western Intellectual Tradition, and Black Atlantic Tradition Edited by Celucien L. Joseph and Paul C. Mocombe

137 T. S. Eliot and the Mother Matthew Geary

138 Orientalism and Reverse Orientalism in Literature and Film Beyond East and West Edited by Sharmani Patricia Gabriel and Bernard Wilson

139 Narratives of Scale in the Anthropocene Imagining Human Responsibility in an Age of Scalar Complexity Edited by Gabriele Dürbeck and Philip Hüpkes

140 Figures of the Migrant The Roles of Literature and the Arts in Representing Migration Edited by Siobhan Brownlie and Rédouane Abouddahab

141 Commodifying Violence in Literature and on Screen The Colombian Condition Alejandro Herrero-Olaizola

142 The Theological Dickens

Edited by Brenda Ayres and Sarah E. Maier

143 Connecting Literature and Science Jay A. Labinger

For more information about this series, please visit: www.routledge.com/ Routledge-Interdisciplinary-Perspectives-on-Literature/book-series/RIPL 


\section{Commodifying Violence in Literature and on Screen \\ The Colombian Condition}

\section{Alejandro Herrero-Olaizola}


First published 2022

by Routledge

605 Third Avenue, New York, NY 10158

and by Routledge

2 Park Square, Milton Park, Abingdon, Oxon OX14 4RN

Routledge is an imprint of the Taylor \& Francis Group, an informa business

(C) 2022 Taylor \& Francis

The right of Alejandro Herrero-Olaizola to be identified as author of this work has been asserted by him in accordance with sections 77 and 78 of the Copyright, Designs and Patents Act 1988.

The Open Access version of this book, available at www.taylorfrancis.com, has been made available under a Creative Commons Attribution-Non Commercial-No Derivatives 4.0 license.

This book is freely available in an open access edition thanks to TOME (Toward an Open Monograph Ecosystem) - a collaboration of the Association of American Universities, the Association of University Presses, and the Association of Research Libraries-and the generous support of the University of Michigan's College of Literature, Science \& the Arts and the Provost Office. Learn more at the TOME website, available at: openmonographs.org.

Trademark notice: Product or corporate names may be trademarks or registered trademarks, and are used only for identification and explanation without intent to infringe.

Library of Congress Cataloging-in-Publication Data

Names: Herrero-Olaizola, Alejandro, author.

Title: Commodifying violence in literature and on screen :

the Colombian condition / Alejandro Herrero-Olaizola.

Description: New York : Routledge, 2021. I

Series: Routledge interdisciplinary perspectives on literature I

Includes bibliographical references and index. I

Contents: Introduction: the Colombian condition-Narco-stories

globalized: Pablo Escobar and excess consumption-

The Ingrid Betancourt story: memory in the times of mass media-

The travelogue boom: dark exoticism for global consumption-

Affective visuality: the cinema of conflict and reconciliation-

Epilogue: post-conflict Colombia? I

Identifiers: LCCN 2021014792 | ISBN 9780367459659 (hardback) |

ISBN 9781032080505 (paperback) I ISBN 9781003195702 (ebook)

Subjects: LCSH: Colombia-In mass media. I Violence in mass media. I

Colombia-Foreign public opinion. I Colombia-Civilization.

Classification: LCC P96.C657 H47 2021 I DDC 303.230861-dc23

LC record available at https://lccn.loc.gov/2021014792

ISBN: 978-0-367-45965-9 (hbk)

ISBN: 978-1-032-08050-5 (pbk)

ISBN: 978-1-003-19570-2 (ebk)

DOI: $10.4324 / 9781003195702$

Typeset in Sabon

by Newgen Publishing UK 
L. Ross Chambers (1932-2017), In Memoriam.

For Laura, my Colombian niece. 
$\because$ Taylor \& Francis Taylor \& Francis Group http://taylorandfrancis.com 


\section{Contents}

List of Figures viii

Acknowledgments $\quad \mathrm{x}$

Introduction: The Colombian Condition $\quad 1$

1 Narco-Stories Globalized: Pablo Escobar and Excess

Consumption

2 The Ingrid Betancourt Story: Memory in the Times of Mass Media

3 The Travelogue Boom: Dark Exoticism for Global Consumption

4 Affective Visuality: The Cinema of Conflict and Reconciliation

5 Epilogue: Post-Conflict Colombia?

$\begin{array}{ll}\text { Bibliography } & 166\end{array}$

Index 


\section{Figures}

1.1 Death of Pablo Escobar (1999), oil painting by Fernando Botero $(50 \mathrm{~cm}$ x $38 \mathrm{~cm})$. Museo de Antioquia, Permanent Collection

2.1 Ingrid de la jungle, book cover (original). Editions Fluide Glacial

2.2 Ingrid de la selva, book cover (FARC) 65

2.3 Operación Jaque, TV series poster, RTVE, Caracol TV 74

2.4 Operación E, movie poster, RTVE, Canal + 75

2.5 Crisanto in Operación E (screenshot; newspaper closeup) $\quad 78$

2.6 Crisanto in Operación E (screenshot; face closeup) 78

2.7 Centro de Memoria, Paz y Reconciliación. Photograph by the author (2014)

4.1 Mirichis in La sirga (screenshot). Contravía Films 123

4.2 Alfonso in La tierra y la sombra (screenshot). Burning Blue Films

4.3 Gerardo in La tierra y la sombra (screenshot). Burning Blue Films

4.4 Falso positivo in Violencia (screenshot). Courtesy of Jorge Forero

4.5 La Cocha Lake seen through broken wood in La sirga (screenshot; nighttime) Contravía Films

4.6 La Cocha Lake seen through broken wood in La sirga (screenshot; daytime). Contravía Films

4.7 Mañe and Manslava in La sombra del caminante (screenshot). Courtesy of Ciudad Lunar

4.8 TV static in La sombra del caminante (screenshot). Courtesy of Ciudad Lunar

4.9 Dusty road in La tierra y la sombra (screenshot). Burning Blue Films

4.10 Alfonso and Manuel covered in ashen dust in La tierra y la sombra (screenshot). Burning Blue Films

4.11 Family house surrounded by fire in La tierra y la sombra (screenshot). Burning Blue Films 
4.12 The empty house in La tierra y la sombra (screenshot). Burning Blue Films

4.13 Movie poster for Jorge Forero's Violencia. Courtesy of Jorge Forero

4.14 Unidentified captive bathing in the river in Violencia (screenshot). Courtesy of Jorge Forero

4.15 Unidentified captive fully submerged in the river in Violencia (screenshot). Courtesy of Jorge Forero

5.1 Detail of Doris Salcedo's Quebrantos. Patrimonio Cultural, Universidad Nacional de Colombia, 2019

5.2 Detail of Doris Salcedo's Quebrantos. Courtesy of Viviana Peretti 


\section{Acknowledgments}

This book would not have been possible without the support and encouragement of many friends and colleagues who have literally and figuratively been by my side over the years. It has been a long and (at times) arduous journey to bring this project to fruition and having them nearby has certainly softened the bumps along the way.

First and foremost, I owe immense gratitude to Ross Chambers for his unconditional support and friendship, for his careful and incisive reading of my work, and for the many wonderful conversations we shared about Latin America and Colombia (and, frankly, the world)-all of which helped me articulate this project to make it more accessible to a wider audience beyond the field of Hispanic Studies. Likewise, I am indebted to Lucille Kerr for her steady mentorship and guidance since the 1990s, particularly for writing letters of support for the fellowships that contributed to the research and writing of this book. In this regard, I wish to thank the Fulbright Program for granting me the US Scholar Fellowship to Colombia, and the University of Michigan for the Michigan Humanities Award. These fellowships allowed me to devote valuable time to researching and writing this book, which occurred in three different locations: Bogotá (Colombia), Ann Arbor (Michigan), and Miami (Florida), where it was finally completed amidst a terrible global pandemic.

Many thanks are due to the wonderful and unique group of Colombianistas, whose positive energy, enthusiasm, dedication, and engaging conversations and scholarship significantly enriched my understanding of Colombia. I am grateful for the opportunities to share my work in academic forums and informal settings with all of them, and, in particular, with María Ospina, Juliana Martínez, María Helena Rueda, Felipe Gómez, Camilo Malagón, Andrés Aluma Cazorla, Héctor Hoyos, Kevin Guerrieri, Juanita Aristizábal, Norman Valencia, Lucía Ortiz, Elvira Sánchez-Blake, Clara Ronderos, and María Mercedes Andrade. While living in Colombia, I was fortunate enough to befriend many young scholars who relentlessly encouraged me to pursue this project. My heartfelt gratitude goes to Chloe Rutter-Jensen, Gregory Lobo, and Gerriet Janssen for the many opportunities to "talk my project out" with 
them and receive incredibly useful feedback. I would be remiss not to mention other scholars in Colombia who likewise showed interest in my work and contributed to my understanding of the field. Among these, I want to thank Marta Cabrera, Jaime Alejandro Rodríguez, and Cristo Figueroa for welcoming me and facilitating my academic appointment at Bogotá's Pontificia Universidad Javeriana, and Carolina Alzate, César Valencia Solanilla, and Juan Manuel Acevedo for their invitations to give talks, respectively, at Universidad de los Andes, Universidad Tecnológica de Pereira, and Universidad del Quindío.

I have been quite fortunate to have amazing colleagues and friends in Michigan whose unwavering support and encouragement proved to be crucial for the completion of this book. I want to express my deepest gratitude to Juli Highfill for being such a gran amiga, Cristina MoreirasMenor for her wonderful and unique complicity in everything I do, Gareth Williams for his dependable support and brilliant sense of humor, and Lorenzo García-Amaya and Nicholas Henriksen for being such a supportive and exquisite pair like no other. I also thank Enrique García Santo-Tomás for checking on me frequently while I was in pandemic isolation. Several current and former graduate students from Michigan with whom I had the opportunity to talk about (and share) my work in formal and informal settings should also be recognized. I am grateful to Alejandro Quin, Talia Dajes, Mónica López Lerma (and consort Julen Etxabe), Catalina Esguerra, Arcelia Gutiérrez (and consort Ben Rodríguez), and, in particular, to Martín Ruiz Mendoza for his help with translations, his careful reading and proofreading of the final manuscript, and for his invaluable skills in securing image permissions in Colombia. I also thank filmmaker Jorge Forero, Ciudad Lunar, Museo de Antioquia, Patrimonio Cultural (Universidad Nacional de Colombia), Editions Fluide Glacial, and Viviana Peretti for some of the images included in this book.

Colleagues from the profession at large and friends were also instrumental in the completion of this book. I would like to thank Marcy Schwartz for being there for me over the course of my academic career and for her constructive feedback on a grant proposal for this project. I am also indebted to Sonia Kane for her advice on publication options for this book. At Routledge, I wish to express my gratitude to Jennifer Abbott for believing in the viability of my project and Mitchell Manners for handling the editorial process to make this book a reality. The comments and suggestions I received from the press's evaluators helped me situate my work within the larger framework of Latin American Studies. My gratitude to Pedro Palou and Luis Duno-Gottberg for their constructive feedback and for reading my materials for the press. For her help in granting me access to the Steven and Dorothea Green Library at Florida International University, I am grateful to Pascale Bécel. For his decades-long friendship and camaraderie, I owe many thanks to Santiago Juan-Navarro, who has always supported all my academic endeavors with the greatest enthusiasm and incredibly good humor. And, of course, 


\section{xii Acknowledgments}

I thank Andrea Fanta Castro for her relentless support, encouragement, and unconditional friendship, her involvement in this project from the start, and for being my number one interlocutor along the way.

For the memorable and unforgettable trips to Bogotá and for sharing their views of Colombia with me, I thank Karen Zilles, Alain Martinossi, and Doug Kaminski, whose friendships over the years have impacted me in many positive ways. For their continued interest in my work and my well-being, I owe gratitude to Guiomar Fages, Alejandro Meter, Jorge Coronado, Daniel Eder, and to a vibrant group of devoted swimmers in Miami who heard me yap about this book for a number of years and gracefully listened-thanks, Alfredo, Kirk, Raul, Lisa, Carla, Lucia, Liz, Luis, Corey, Chris, Dino, José, Nacho, David, Peter, Andrés, and Lemuel.

And finally, I would like to mention those close to me who left this world while I was completing this book, my brother Jose and my friend Ross. I felt their presence and never forgot their imprint on my life throughout these pages. 


\section{Introduction}

\section{The Colombian Condition}

For a long time, I have been thinking about how best to talk about violence in Colombia without falling prey to broad statements such as "Colombia is a violent country" or "violence rules Colombia." These statements have contributed to the pervasiveness of Colombia's cultural representations of violence globally, be those carried out by Colombians themselves or by others outside Colombia. Wary as I am of such generalizations, which, frankly, could apply to many countries in the world (including the US, from where this book originates), when asked if Colombia is a violent country I would typically respond yes, but provide an important caveat: not more so than many other nations around the world facing social inequities and civil unrest. The preconceived notion that violence is intrinsically ingrained in Colombia's national fabric has fueled a dominant stereotyping in the media which perpetuates the idea of a "hostage nation" irremediably caught in a web of endless drug trafficking, kidnappings, paramilitarism, guerrilla warfare, and human rights violations. This view is somewhat reductive and tends to espouse the idea that there is such a thing as "Colombian violence"-a rather homogenizing category in which very different iterations of violence are lumped together in a rather simplistic fashion. For one, it attaches violence to a country's identity and, in so doing, it relays that there is a specific, home-grown violence that implicitly defines and becomes the identifier of Colombia. This is problematic because it equates violence and Colombia and makes both terms almost interchangeable-as if one did not exist without the other. As we know, not everything emerging from Colombia is violent (and not everything is peaceful, of course) but this view of "Colombia, the violent nation" has important repercussions for cultural production and dissemination, because the assumption and misconception in the global cultural market have long been that, if something comes from Colombia, it has to be violent or, at least, originate in violence.

This became evident to me when I started traveling to Colombia around 2006 and soon realized, by the kinds of reactions I received, that for most people I was putting myself in danger by going there. At a modest height of five foot seven and a slim body of 135 pounds (not quite the 


\section{Introduction}

imposing figure that would detract anyone from potentially harming me), I have been fortunate enough not to experience any violent acts during my time in Colombia or witness them in close proximity. While sharing my personal in-country experience may seem trivial, I include it here to establish my positionality as the foreign "I"/eye seeing and reading Colombia, as someone coming from outside Colombia-born and reared in the Basque Country (a region in Spain, let's say, not unfamiliar to civil unrest and terrorism) and educated in the US-who has drawn from his travel and research experiences to write about violence and cultural production. My positionality is also important to contextualize that my primary interest is to read Colombia and its cultural production beyond national borders and within a framework of global flows, where cultures, people, and places circulate widely and, as a consequence, are constantly being reimagined.

Having said that, and fully aware of the privileged position enjoyed by those like me who look at violence from a distance (or those who have managed to escape it), Colombia has decidedly experienced, as Jean Franco reminds us, cruel forms of violence throughout its history (e.g., body dismemberments such as the infamous "necktie cut" in decapitation practices). Cruelty in Latin America has been not only practiced by governments (through torture, suppression of dissidents, cleansing of racial and indigenous minorities) and criminal groups (e.g., drug cartels, paramilitary groups), but its exploitation for entertainment purposes in film, television series, and other cultural products has become a "feature of modernity." This is the "cruel modernity" characteristic of neoliberal capitalism, which often results in "a casual violence without limits" (Franco 2-15). The familiarity (and proximity) with such "casual violence" is an important component in the processes of cultural commodification of violence, which is the main focus of this book.

More specifically, in what follows, I investigate the pervasiveness of "Colombian violence" as a profitable cultural brand that is being exchanged and widely disseminated in the global cultural market. The appropriation of Latin America for global cultural production is not an entirely new phenomenon. Since the Boom years (1960s-1970s) onward, Latin America has increasingly become a viable commodity for the culture industry around the globe. Boom writers such as Gabriel García Márquez, Julio Cortázar, and Carlos Fuentes, who gained notoriety for their crafty storytelling and innovative style are now internationally recognized figures forever associated with the Latin American brand of magical realism. But those same years were also the decades of political instability and social violence and unrest for many Latin American nations. Following the 1959 Cuban Revolution, the region endured oppressive political regimes and economic crises, while it also took center stage in media reports, artistic and intellectual circles, and geopolitical strategy (the Cuban missile crisis comes to mind). This new attention to Latin America made its cultural production (mainly literature, art, 
and film) an oft-sought commodity on the worldwide cultural market. Defined by an apparently contradictory conflation of magical and harsh realities, Latin America's global image during the Boom years attracted international readers who, aware of the political upheavals in the region, were made more sensitive to its many social injustices. One result was that these realities became highly profitable in the global marketing of non-European cultural goods, and Latin America was launched onto the international scene.

Five decades after the Boom, which was marked by the death of its most important figure, the Colombian writer Gabriel García Márquez (1927-2014), Latin America continues to be part and parcel of cultural marketing, but with a new development that emerged in the 1990s. Nowadays, transnational enterprises seem perfectly satisfied with the commodification of Latin America's violent realities for the worldwide cultural market. But by capitalizing on the dire effects of globalization in the region (e.g., social inequalities, displacement, poverty, and exploitation), large-scale cultural producers like the publishing and media giant Bertelsmann-following the marketing strategies that were so profitable in the 1960s and 1970s-have now secured an endless supply of "dirt" (or "grit") for massive distribution. Latin American writers and cultural producers, for their part, actively cooperate in this effort by continuing to produce, for instance, novels in which the magic is gone, having been replaced by detailed (and often exoticized) depictions of the violence now facing the region. The literary and cultural market now seems avid to reinforce readers' knowledge of Latin America's "darker side" (human rights violations, kidnappings, narcotics warfare, collective traumatic experiences, or economic hardships) by focusing on specific local conflicts chosen for the interest they are likely to attract in the global market and, as a consequence, deterritorialization ensues.

The case of Colombia has become emblematic, albeit unfairly so, of Latin America's social reality as a whole. As such, violent scenarios emerging from Colombia are easily commodified in best-selling fiction, television and film, and art, and successfully marketed in North America and Europe precisely because they provide international audiences with a sense of history, justice, and false proximity between them and localized marginal subjects. In consuming these violent stories, such audiences are made to feel more aware of Latin America's harsh realities, reassured in their knowledge, and "closer" to the struggles facing its marginal subjects. In this regard, Hermann Herlinghaus has proposed that such cultural consumption takes place "without guilt," as gruesome narratives from the so-called "Global South" promote new affective relations to violence in global consumers who engage with (and enjoy) the spectacularization and fetishization of violence originating in the South-a cardinal point that has to be understood in a broad sense. There is no guilt in the global cultural consumption and promotion of such "aberrant transnational artistic representations" despite the fact that they reinforce the existence 


\section{Introduction}

of global inequalities under a new cultural imaginary (Violence 6). While readers become more aware of such inequalities by reading or watching films about them, the original localities remain pigeonholed as the loci of violence for continued cultural appropriation in the global market. Through South-by-North marketing operations and in accordance with neoliberalist economic practices that foster social inequality and violence, these cultural representations provide these global consumers with a sense of proximity toward marginal subjects, as Latin American culture is often packaged and sold by publishing and media conglomerates practicing the pervasive US-style of multiculturalism that is purveyed by the global culture industry.

Such proximity and presumed familiarity on the part of international audiences are triggered by gruesome media reporting on narcotics warfare, kidnappings, and guerrilla or paramilitary activity as well as by a plethora of traumatic personal accounts that constantly define Colombia as a "sick nation" suffering from chronic violence, if you will, from a "violent condition." As I disentangle the commodification processes that perpetuate the darker side of Colombia for worldwide consumption, my book explores precisely this "condition" that has led writers, filmmakers, and artists to embrace (purposefully or not) the incessant violence in Colombian society for their own creative endeavors and to do so through mass-marketed cultural products such as narco-stories, captivity memoirs, gritty travel narratives, and films about conflict and reconciliation. As participants in and purveyors of the Colombian condition in the global cultural market, producers cannot escape market demands for easily commodifiable forms of violence. In this book, examples can be found in best-selling narco-stories by Fernando Vallejo, Laura Restrepo, Juan Gabriel Vásquez, or Nam Le; artwork by Doris Salcedo and Fernando Botero; gritty, "dark tourism" travelogues by Ramón Chao, Matthew Thompson, or Stephen Smith; bestseller captivity memoirs by Ingrid Betancourt and Clara Rojas; and globally distributed narco-soap operas and independent films. These cultural products present themselves as historically grounded (and not simply as pulp), and, given their popularity, reveal a certain level of addiction to "all bad things Colombian" on the part of readers, critics, and media outlets worldwide.

This condition-understanding the word "condition" in its multiple usages, as a premise, as an ailment, and as bringing (something) into the desired state for use-has been experienced by cultural producers, who are tied to niche-market expectations to point that their creations will not typically circulate widely unless they fall under the moniker "Colombian violence." This conditionality for (and conditioning of) cultural production can be equally observed in Mexico, Central America, or Peru, and therefore Colombia has served as a model for similar cultural commodification of violence from other parts of Latin America, where the illicit drug trade has made significant inroads. Think, for instance, of the Mexican War on Drugs (2016 onward) and its extensive cultural 
production drawing from violent scenarios to produce narcocorridos (e.g., Los Tigres del Norte, Los Tucanes de Tijuana), documentaries (Shaul Schwarz's Narco Cultura, Matthew Heineman's Cartel Land), films (Amat Escalante's Heli, Gerardo Naranjo's Miss Bala and its US adaptation by Catherine Haardwicke, Denis Villenenuve's Sicario), short stories and chronicles (Carlos Monsiváis's Viento rojo, El blog del narco), and fiction by Élmer Mendoza, Luis Humberto Crosthwaite, or Yuri Herrera-all of which fit within current culture-market expectations that would place Mexico as yet another "violent country" in Latin America following in the footsteps of Colombia. This extensive body of work on Mexican cultural representations of violence that emerged as a result of the War on Drugs falls out of the scope of my book, but there are obvious similarities in the cultural commodification of violence in both countries. But, while Colombia and Mexico are often being compared through their narco-representations and their status as "failed states," it is important to note that there are major significant historical contexts in which violence has emerged and proliferated-for instance, the involvement of guerrillas and paramilitaries in drug trafficking, decades of civil war conditions since La Violencia in the case of Colombia, or the long history of one-party rule in Mexico under the PRI for over 70 years $(1929-2000){ }^{1}$

\section{Colombia as a Failed State: Critical Approaches to Violence}

Before I delve into my analysis of cultural commodification, it is important to offer some historical context to dissect the significance of "Colombian violence" as a brand in the global market. A quick rundown of Colombia's modern history shows that violence has often signposted major foundational historical events that are clearly anchored in civil unrest and warfare. Likewise, violence has experienced a series of transformative leaps to perpetuate the State institutions, the preservation of land ownership, and the political elite's hold on power. Think, for instance, of the War of a Thousand Days between liberals and conservatives (1899-1902); Panama's independence and secession from Colombia (1903); the eruption of $\mathrm{La}$ Violencia following the assassination of the Liberal Party's presidential candidate Jorge Eliécer Gaitán (1948-1958); the formation of left-wing guerilla groups such as the FARC (Fuerzas Armadas Revolucionarias de Colombia) and the ELN (Ejército de Liberación Nacional) in 1964; the irruption of the M-19 left-wing urban guerilla in the 1970s and its assault on the Colombian Supreme Court in 1985; the assassinations of members of Unión Patriótica-the left-wing party founded by the FARC and the Colombian Communist Party-in the late 1980s; the drug-related criminal activity and gruesome violence under the Medellín and Cali cartels (1980s-1990s), which included warfare with armed groups such as MAS-Muerte a Secuestradores (Death to Kidnappers)—and Los Pepes, a vigilante group protecting those "Perseguidos por Pablo Escobar" 


\section{Introduction}

(Persecuted by Pablo Escobar); the upsurge of right-wing paramilitary groups such as Autodefensas Unidas de Colombia (AUC) that resulted in the massacre of civilian populations in the 1990s-2000s and in the formation of BACRIMS (bandas criminales [organized crime gangs]) emerging around 2006; the assassination of falsos positivos (innocent civilians lured by the army to accept non-existent employment opportunities in order to execute them extrajudicially as alleged guerilla combatants) between 2002 and 2008; the upsurge of new paramilitary activity (often combined with organized crime) such as Autodefensas Gaitanistas de Colombia (AGC) in 2008; and the appearance of the left-wing urban guerrilla Movimiento Revolucionario del Pueblo (MRP) in 2016; and the list goes on. ${ }^{2}$

Against this backdrop, and due to these various iterations of violence, Colombia has many dubious distinctions: the country with the world's highest per-capita rate of people who are displaced (six million), disappeared (about 80,000), injured by landmines $(14,000)$, and victims of violent crimes (eight million) and homicides (1.6 million), including one of the world's highest rates of assassinated journalists (UNESCO). Overall, more than 200,000 people have been killed in the armed conflict altogether in the five-decade long de facto war, which far exceeds the estimated number of desaparecidos in Chile and Argentina combined (about 40,000) during the Southern Cone dictatorships of the 1970s ("Los números," El Tiempo; Martínez, Haunting 1-2). As the country seeks closure to decades of warfare, displacement, and human rights abuses, efforts directed toward the reconstruction of historical memory and national reconciliation began to take center stage in 2013 with the publication of the 450-page report ;Basta ya! Colombia: memorias de guerra y dignidad [Enough is Enough! Colombia: Memories of War and Dignity]. This report came out when peace negotiations between the FARC guerrilla and the government were underway in Havana, Cuba (2012-2016). The signing of the Peace Accords in 2016 between the FARC and the Colombian government was to put an end to these startling numbers. The Peace Accords signed in June did not garner sufficient popular vote support in the national referendum held in October and had to be modified and approved by the Colombian Congress in November. Meanwhile, there is no agreement yet with Colombia's "other" guerrilla, the ELN, while dissident factions from the FARC have continued bellicose activities throughout the country and more than 1,000 social activists and community leaders have been murdered by new paramilitary forces. Given this scenario, the efforts to enact a comprehensive peace deal continue to face a tough opposition from some sectors of the population and rightwing political factions (e.g., Uribistas), which have been crying foul since revelations in 2016 that the FARC guerrilla had assets worth 10.5 billion dollars, as reported in The Economist's piece "Unfunny money." Under this tense political climate, the roadmap to a "post-conflict Colombia" is challenging (to say the least), since the implementation of the Peace 
Accords (e.g., the special tribunals for guerrilla combatants, land restitution) is constantly hitting roadblocks.

As can be surmised from this condensed history of modern Colombia, there are different iterations of violence-often lumped together as "Colombian violence"-, when, in fact, the groups being affected, their political agenda, and the historical context in which they occur cannot be reduced to that label. Bruce Lawrence and Aisha Karim's anthology On Violence posits that "violence is always and everywhere historically contingent" and, as such, is "mediated through individuals." In their formulation, violence is "not intrinsic to the human condition or social structure," since individuals and society are complicitous with actual or potential expressions of violence (6). Thus, violence is better understood as "a link-chain" because it is "neither stable nor predictable": "Violence is always and everywhere a chain because chains are always and everywhere subject to change, whether from below or above, by actors or by observers" (13). This link-chain approach is fruitful to understand violence in Colombia because of its changeability and adaptability as new violent actors become stakeholders in the conflict. It also sheds light on my efforts to disambiguate "Colombian violence," as I move away from any essentialist approach that reads Colombia as "naturally violent."

In this regard, several scholars propose the term violences (in the plural) to address the multiple and diverse iterations of violence in Colombia. For example, Rory O'Bryen argues that "this singular 'thing' called La Violencia is in fact a composite of multiple 'violences', each of which is inscribed in its own temporality of uncertain ruptures and broader continuities" (Specters 5). Likewise, Daniel Pécaut sees violence in Colombia as an amalgamation of multiple actors vying for the preservation of resources and spaces, thus generating a multiform and everchanging violence that is often (wrongly) seen as one violence. For her part, María Helena Rueda sees violence as a continuum within a contextual and relational modality that functions at the "individual and collective level" (La violencia 11). This can be exemplified in the versatility and quick adjustability-according to the changes in political scenariosof paramilitary groups (from AUC to BACRIMS, and, more recently, AGC), which have been typically supported by landowners in rural areas seeking to preserve the stability and resources of their territories, where violence has often been "the norm." In this connection, Juana Suárez focuses on the normativization of violence in Colombia and the "sites of contention" that define the country's history of violence and cultural production. She brings in the media conglomerates as culprits in the consecration of a spectacular and "reiterative discourse of violence" (14). Such a discursivity reinforces the notion of a "systemic violence" (Žižek) that is anchored in economic inequalities fostered by global financial systems, ultimately "normalizing" poverty and precarity. The spectacularization for cultural consumption, Suárez reminds us, rarely dissects the coexistence of political and criminal violence. This, ultimately, homogenizes the 


\section{Introduction}

multiple iterations of violence and perpetuates the understanding that the latter is perennial, intrinsic, and systemic in Colombia. ${ }^{3}$

Relating to systemic violence, Ileana Rodríguez in "The Violent Text" suggests that, since Colombia remains a failed state as a result of the 19th-century struggles for independence (mainly between liberal and conservative factions), it is more appropriate to talk about a composite civic, social, and economic violence. This resulted in a dysfunctional state that did not provide "the locus of national meaning, moral authority, and legitimacy" (96). As a consequence, a cultural tradition of violence emerged between the civil society and the State (i.e., the apparatuses and structures of power) that ultimately makes it difficult to imagine the concept of "national individuals pertaining to a community," thus resulting in an "incomplete state formation" or a failed state (96-101). Paradoxically, as a "failed state," Colombia has been a democracy for most of its recent history, an unusual case in the Latin American context, and has staved off coup d'etats or dictatorial regimes despite decades of civil war conditions. This apparent contradiction-the "incompleteness" of the State that still affords an (arguably) "stable and durable" democracy, which Bushnell encapsulates in calling Colombia "a nation in spite of itself"-further complicates the conceptualization of violence: "the social conflicts are so multiple and so inextricably articulated with each other that the clear-cut divisions between one moment of violence and the next are only relatively established" (Rodríguez 104). ${ }^{4}$

Part of this complexity lies in the intertwinement of political and criminal violence in Colombia-that is, broadly speaking, State violence and violence committed by common criminals. For example, if we follow Walter Benjamin's approach, the State's main interest in violence is to preserve existing laws. In Colombia, this "law-preserving violence" is typically carried out not only by the State and its surrogates, the paramilitaries, who preserve the existing laws, but also by the drug traffickers, who use violence to preserve the laws and the political status quo that, in the end, allows them to continue with their illicit activities. In exploring the relationship between power and violence, Hannah Arendt argues that "power is indeed the essence of all government but violence is not. Violence is by nature instrumental; like all means, it always stands in need of guidance and justification through the end it pursues" (241). And, thus, violence is enacted whenever power is in danger. This is particularly cogent for Colombia, given that power has long been put to the test throughout the country's modern history, warranting the instrumentality of violence to "preserve the law" and maintain the power institutions of the State. The election of Pablo Escobar to Congress illustrates the power of narcopolitics and the fact that drug lords sought to partake in the democratic institutions not necessarily to challenge the established legal framework (or overthrow the State) but to work within the existing legal framework, for instance, to adjust extradition laws or choose the preferred location to be imprisoned (e.g., Escobar's own-designed "prison" La Catedral): “All 
violence as means is either law-making or law-preserving. If it lays claim to neither of these predicates, it forfeits all validity" (Benjamin 275). In this formulation for the case of Colombia, the State's violent means to preserve order (and the country's laws) are also enacted by rogue actors of the State and criminals in the armed conflict, and therefore "enemies of the State" (cartels, BRACIMS), who are outside the law, in effect, are preserving the "failed" State and its laws. As a consequence, it is often hard to discern victims and enemies, friends and victimizers, particularly in rural areas where the armed conflict brought together multiple (and often indistinguishable) warring factions. ${ }^{5}$

This apparent interchangeability of the actors in the conflict (or "violent pluralism" [69] in Martínez-Durán's words) reinforces the notionfor example, in media representations and in the marketing of cultural production-that all violences in Colombia boil down to one homogeneous, singular, and monolithic entity; more so in the case of global appropriations and dissemination of Colombia's cultural production, as the neoliberal market is keen on selling ready-made, packaged versions of the conflict for their "entertainment" value, a shared sense of social awareness, and presumed proximity to marginalized subjects. Fernando Rosenberg's study on the transnational and global circulation of human rights is very illuminating in this regard. He posits that, in the new neoliberal state configuration, the market is presented as the locus of difference, of inclusion, and of the empowerment of individual consumers who are often participants in buying and selling operations of a global responsibility but with a certain distance from marginalized subjects. In the specific case of Colombia, he reminds us that the constitutional reform of 1991 fully fits within neoliberal expectations: free market ideas combined with the expression of human rights and their institutional inclusion within the so-called market-state.

My interest in this book is precisely to explore these market-driven dynamics in relation to "Colombian violence" through transnational media operations that favor "the homogenization of identities" and a certain level of gratification and ethical position-taking on the part of global consumers (Rueda, La violencia 164). ${ }^{6}$ As I will discuss, the commodification of violence that began to emerge in the 1990s branded Colombian literature, film, and art as preferred loci of violence for cultural consumption "without guilt" and with a sense of social justice and awareness. As global readers, filmgoers, and television watchers embraced the false sense of proximity and reinforcement of their security that such representations provided, the culture industry promoted a specific type of Latin American culture that "markets off" marginalized subjects.

\section{Consuming Margins: Dirty Realism and the Cultural Field}

The commercialization of marginality is fairly well established in the literary and cultural fields, as attested by the publishing success of dirty 


\section{Introduction}

realism (realismo sucio)—one of the labels that seem to have taken over the legacy of magical realism-and its appropriation in best-selling Latin American fiction. Let's consider, for instance, the writings of Pedro Juan Gutiérrez (the putative father of this kind of literary best seller in contemporary Latin America), whose "excremental" narratives in Trilogía sucia de La Habana (1998) are loaded with gritty and repetitive portrayals of Cuba as a country in ruins with crumbling infrastructures, or the political thrillers by the Chilean writer Roberto Bolaño that revisit the atrocities committed by the Pinochet regime in works such as Estrella distante (1996) and Nocturno de Chile (2000), or novels that chronicle the drug war along the US/Mexico border such as Élmer Mendoza's narco-thrillers Un asesino solitario (1999) or Balas de plata (2008). These authorsalong with Colombian counterparts such as Fernando Vallejo or Jorge Franco-have been widely distributed and translated into English as well as into major European languages, and have generated (and benefited from) a growing literary niche-market in which the crude realities of Latin America accrue interest for global cultural production. ${ }^{8}$

Gutiérrez, for instance, promises his readers reiterated and in-detail descriptions of sex acts and distasteful and eschatological scenarios related to lower-class and marginal characters who seem content with wallowing in stinky sweat, excrements, spurting semen, or vaginal fluids as part of their daily lives. Readers of dirty realism, in turn, consume these descriptions and confirm their preconceived ideas about the precarious conditions of the inhabitants of Havana, revelling through a voyeuristic taste for dirt in a narrative that combines social chronicle, eroticism, and autobiography. This type of cultural consumption reinforces international audiences' privilege as they experience "dirt" from a distance, from the comfort of their homes in the "first world," which is in line with Herlinghaus's proposal of "violence without guilt" in regard to cultural production from the South being consumed in the North.

Dirty realism does partake in the culture of excess that has become prevalent in neoliberal Latin America, whereby excessive wealth and extreme poverty are linchpins of the capitalist economy in a globalized world. Contemporary Colombian writers, as they move away from magical realism, have embraced some of the tenets of dirty realism for their fictions, and, in so doing, have published novels that are exemplary of a niche in the literary market based on the fictionalization of the social hardships in Latin America and on the construction of marginal characters who are suitable for mass consumption. While not embracing the eschatological detail that we see in Gutiérrez's narratives, Colombian authors do share a knack for marginal characters living in the slums as well as crude and violent scenarios that are fraught with danger and social inequities. Colombian novels such as Fernando Vallejo's La virgen de los sicarios (1994), Jorge Franco's Rosario Tijeras (1999), Mario Mendoza's Satanás (2002), Laura Restrepo's Delirio (2004), or Juan Gabriel Vásquez's El ruido de las cosas al caer (2011) reproduce the commercialization of 
these margins and promote a certain tendency to exoticize the harsh realities of Latin America, tailoring them to an audience that is aware of and informed about the socio-political conditions in the region and eager to read something new, but with a certain "cultural weight."

It is no coincidence that these Colombian authors have established themselves as a key group in the publishing dynamics of selling and buying the Latin American margins. This is the case even if in Colombian literary narratives the eschatological component is set aside and gives way to social chronicle and to violent and delirious scenarios that international readers identify as inherently Colombian. Locating these narrative works between Medellín-"the damned city," "this delirious city" (La virgen 39; 61), which "always wins in the end" (Rosario 95)—and Bogotá, a city possessed by demonic forces (Satanás), or anchored in a past of madness in the family and at a national level (Delirio), Colombian contemporary narrative appears anchored as a global bestseller dispenser of such ills-the most commercially successful being narratives about violent drug traffickers, sicarios (paid assassins), and characters in mental distress. ${ }^{9}$ Gabriela Polit Dueñas sees this phenomenon as the result of a shift "in the cultural imaginary of the region" that has emerged as a result of the transformation of the "political, social and economic order in Latin America"-its most direct consequence being the creation of hybrids like "the epic feat of narcocorridos" or, clearly making reference to Fernando Vallejo's sicarios, "new manifestations of the religious sentiment in which the devotion for the Virgin is also a plea for a good shot to kill" ("Sicarios" 119-120). Publishing houses like Alfaguara and Seix Barral, two publishing giants in the Hispanic literary world, have included in their lists authors who disseminate through their novels such socio-political transformations and hybrid cultural products. ${ }^{10}$

I find George Yúdice's study of global media conglomerates and their relation to Latin America to be very enlightening to explore the commodification of Colombia's violences through global publishing that started in earnest in the 1990s. Yúdice argues that we are facing a new form of cultural production, in which the cultural industry operates in multiple locations: "the outcome is the transformation of cultural production into a maquila [whereas] the production process is controlled from abroad to reduce cost of the cultural labor in the original localities" ("La reconfiguración" 648). These maquiladoras or maquilas are assembly plants in Mexico that manufacture finished goods for export and are typically owned by non-Mexican corporations. Yúdice aptly sees today's culture industry as part of the assembly-line production that is characteristic of global trade, and that has led to an increasingly viable and profitable commodification of Latin American cultural products (literary texts, films, documentaries, arts and crafts, etc.) worldwide. His understanding of an assemblage in the cultural industry follows a transnational movement in which "there are command and control centers in the cultural industries, and even when the production does not come 


\section{Introduction}

from those centers, the profits will accumulate in the companies that are settled there" ("La reconfiguración" 641). ${ }^{11}$

This transnational effect has a very significant impact on the publishing industry because the buying and selling of cultural difference (as promoted by the US-style of multiculturalism) becomes commonplace in the global dissemination of Latin American literature. This ignites (even more) the fire that seems to bring independent publishing houses to ashes-houses that used to advocate for the publication and distribution of non-mainstream or "marginal" literature. In the case of Colombia, for instance, we face not only Alfaguara's intervention to universalize the local phenomenon of Medellín's slums but also a maquila effect by which the latter's literary production is controlled from the outside and is advertised in Europe, Latin America, and the US. The most immediate outcome of these local appropriations tailored to the global market from abroad consists, according to Yúdice, in the search for bestseller novels by conglomerates such as Bertelsmann and by large booksellers. As a result of this phenomenon and the lack of an entrenched philanthropic culture in Latin America, cultural production complies with current publishing market trends-namely, to the whims of the neoliberal market that seeks to turn localities into global products for consumption in the international realm.

In this book, I argue that ready-made products as narco-stories, gritty travelogues, or captivity memoirs provide a wide public with the possibility of training themselves as readers, creating the false illusion that readers can actually choose, when, in fact, they are subjected to global networks of understanding more than what it may seem at first sight. In accordance with neoliberalism's tenets for a wide market diversification, local and global visions become intertwined, as cultural difference and marginality are fetishized (and commodified) creating an illusion that readers and consumers have agency toward situations that are localized in any part of the planet. This is why Latin American cultural products of the 1990s have been so successful (particularly in North America): because they provide the North with a sense of history and justice, despite their "unbearable lightness of history" (levedad histórica is the term used by Francine Masiello) and the illusory proximity they mediate between readers and localized marginal subjects (811). This false proximity between global readers and the marginal subjects they read about in Colombian cultural production produces in the reader a double fantasy of identification and displacement regarding the novelized subjects. I consider this to be crucial for the analysis of recent Colombian cultural production because the familiarity of international audiences with drug trafficking, the FARC guerrilla, paramilitary warfare, and the socio-political effects of these phenomena in Colombia fits well into the spectacular expectations that are associated with the historical levity of our contemporary best seller, and with Latin American global cultural production. 


\section{Translocalities of Violence and the Colombian Diaspora}

Within this global context of cultural production, Colombia's image continues to remain forever tarnished as the locale for ingrained violence, and most of its artistic output continues to reproduce this image as expected (and often required) by international consumers. Places like Colombia's Medellín (similarly, a case could be made for Mexico's Sinaloa) are now being integrated through the marketing operations of the culture industry into a global frame of reference in which localities are being redefined and reimagined globally. But, as Polit Dueñas reminds us, the phenomenon of "narco-narratives could not be wholly understood [...] without fully acknowledging the impact the narcotics trade has had within the cultural scenes of these cities" (Narrating narcos 2-3). And while it has been typically the case that writers and artists tend to help their local communities cope with the effects of violence through their cultural production, it is also true that the commodification of Colombia's violences has rendered such cultural interventions ineffective due to global cultural market demands in which the producers and distributors from the North help disseminate "marginal views" emerging from the South (e.g., stories of poverty, displacement, and human rights abuse). As a result of this type of circulation, today's culture industry operates in an expanded market that produces in one location and processes or promotes its merchandise in many other locations "in an effort to lower the cost of cultural labor in the original localities" (Yúdice, "La reconfiguración" 648). ${ }^{12}$ This transnational appropriation of cultural production exerts a rather alarming impact, for instance, on the publishing industry, since most publishers now only seek best sellers that appropriate formerly marginal localities for global consumption. "Colombian violence" is now bought and sold by media conglomerates in an operation that is reminiscent of colonial practices. Latin American subject matter is extracted for worldwide consumption with only residual benefits (if any) for the original localities.

This type of appropriation continues to take place at a time when Colombia itself faces a historic crossroads. As tensions between Colombia and its neighbors (Ecuador and Venezuela), for the most part, have remained in check since the departure in 2010 of President Álvaro Uribe-a staunch US ally in the global "War on Terror"-, it is important to keep in mind the geopolitical importance of Colombia as a link between Central America (read Panama) and South America, a link that must also be taken into account by the forces of global trade, which also includes, albeit with less economic impact, the culture industry. My ultimate aim in this book is to contextualize the Colombian condition within this historic crossroads and the parameters of the global economy while concentrating on the commodification of violence for cultural consumption. In my book I offer a hemispheric approach to the role played by Colombia in cultural production across the continent and beyond. 


\section{Introduction}

In this regard, Arjun Appadurai's study Modernity at Large is important to understand these processes of a global appropriation of Latin American culture. ${ }^{13}$ Appadurai offers us an in-depth relational argumentation about the role of media in the construction of self-images in the global context. His theoretical model originates in an examination of the disjuncture that separates economy, politics, and culture: "even an elementary model of global political economy must take into account the deeply disjunctive relationships among human movement, technological flow, and financial transfers" (35; my italics). As a result of this disjuncture, we participate in the construction of "imagined worlds" created by global flows. In the case of Latin America, such transnational flows lead us to inquire about the "inside" and "outside" representations purveyed by the global culture industry. Thus, this region is being viewed beyond the Americas through a double inside and outside perspective, which often produces dislocated and converging views of Latin America. My analysis focuses on such overlapping views by examining the translocal effect dominating in Colombian cultural production, which illustrates the incorporation (and consumption) of Latin American violent localities within the framework of global cultural and economic flows.

This goal entails an exploration of the transnational flows and intercultural forces that have resulted in the heterogeneity and fluidity of present-day Latin America-a region that I now see as a cultural and intellectual space that expands beyond the Americas in response to the diminished powers of nation-states. The fact that an estimated five million Colombians (that is, more than one Colombian out of every ten) now live abroad illustrates the argument that Latin Americans can no longer be boxed in or confined to a particular locality. The cultural products I examine in this book precisely respond to the cultural fluidity that is characteristic of today's Latin America and its diasporic communities, particularly in the US, where they are often featured in Spanishlanguage media in major enclaves of the Latin American community (Miami, New York, Los Angeles, or Chicago). For instance, ColombianAmericans in the US have a substantial growing population, which was estimated to be over a million in 2017 according to census data (López, Pew Research Center). For Saskia Sassen, the translocation of space (say, from the "real" to the "imagined" Medellín) is a key component of globalization in terms of the relationship between location and production. As capital becomes more (and more) transnational, so does cultural commodification and the diversification of global localities from where such cultural production originates. These translocalities, in which we are deterritorialized spectators sharing “imagined communities" (Anderson), result from the diminished power of nation-states inscribed in "spatiotemporal assemblages," that is, global localities that are created through mass migrations, technological flows, and financial transfers.

The Colombian transnational identity that such migration flows have produced significantly contributes to the cultural commodification 
of violence and its dissemination, as local diasporic communities in the North avidly consume cultural products from the South as a linkage with the home country, for instance, through watching (the hugely popular) narco-soap operas coming from Colombia. In this connection, María Elena Cepeda explores the relation between the international marketing of Colombian music (e.g., Shakira, Carlos Vives) and diasporic Colombians. In Musical ImagiNation, she argues that the popular success of these Latin music stars along with the growing Colombian diaspora counteracted the stigmatization of Colombia's contemporary violent history. No doubt, the culture industry has cleverly taken advantage of the new market possibilities brought about by the increasingly affluent transnational Colombian and Latin American communities in the US. But, despite these efforts to destigmatize Colombia, the translocations of violence such as Medellín are still being commodified and integrated through the marketing operations of the culture industry into a global frame of reference that perpetuates the appeal of such communities for consumption "without guilt."

This can be seen in the recent musical collaboration between Colombian pop star Maluma and Madonna for their hit-song "Medellín" (2019), whose lyrics (in English and Spanish) perpetuate the city's sempiternal relation to drug culture:

I took a pill and had a dream [...] I took a sip and had a dream / And I woke up in Medellín [...] Ven conmigo, let's take a trip [...] Que estamos en Colombia / Aquí hay rumba en cada esquina [...] Dame eso que tú estás tomando.

We are in Colombia / Here there is a party in every corner. Give me what you're taking.

Set up as a dream-like "trip" to Medellín (not exactly on an airplane), the song reimagines this Colombian enclave as a translocality where fun, reverie, excess, and drug consumption abound. This appropriation of Medellin illustrates the shared and imagined views of this city in the global context and exemplifies its commodification through Madonna's catchy ditty. And, more importantly, it exposes "the unbearable lightness of history" that often deterritorializes violent scenarios by extracting its most spectacular components to the point that violence "loses gravity," as it is translocated and transposed-and, in this process, violence gets "lost in translation." It is, in effect, detached from the harsh realities on the ground that foster and trigger actual violence in local communities. ${ }^{14}$

\section{Reading the Colombian Condition}

In the chapters that follow, I propose a series of illustrative case studies of the Colombian condition and of the translocation of Colombia in the global cultural market. I begin with the proliferation of cultural products 
about the life and times of Pablo Escobar, the infamous drug cartel leader and popular folk hero, who is the example par excellence of the ways in which the Colombian condition is commodified by today's publishing and media conglomerates. In particular, I study the cultural commodification of narco-stories through art, literature, television, and film. Anchored in the infamous history of the drug trade in Colombia, I examine Fernando Vallejo's La virgen de los sicarios (1994) and Juan Gabriel Vásquez's El ruido de las cosas al caer (2011), art by Fernando Botero and Medellín's local muralists, the television series Entourage (2009), the documentary film Pecados de mi padre (2009), and narco-soap operas such as Sin tetas no hay paraiso (2006). I argue that these cultural appropriations of marginality - which have defined the cultural field in Colombia from the 1990s into the 2010s-exemplify the cultural market's logic behind Escobar's cocaine trade, anchored in what Michael Taussig has coined as an economy of delirious consumption and excess. By delving into the South-by-North market dynamics that link that economy with deeply rooted colonial practices, my analysis articulates a cultural critique of the commodification of Latin American crime stories for global consumption, resulting in profitable and exportable cultural goods anchored in excess consumption.

Moving forward into another iteration of violence (FARC hostages), I continue in Chapter 2 with an exploration of the global media frenzy that surrounded the kidnapping and eventual liberation of Ingrid Betancourt in 2010. Through my examination of a wide range of cultural products, such as the French comic book Ingrid de la jungle (2010), Betancourt's captivity memoir Even Silence Has an End (2010), the television series about her rescue Operación Jaque (2010), and the film Operación E (2012), I study how the Betancourt story illustrates the conditions that have led to a market-driven appropriation of the memoir (and memory) boom-and its ties to Latin American narratives of testimonio-that have dominated the global cultural field in recent years. By offering a contrast between the commodification of memory as an individual asset available for global consumption and the collective approach of governmental entities such as the Centro Nacional de Memoria Histórica (National Center for Historical Memory), I show that the process of reconstructing the atrocities of conflict in contemporary Colombia is a heterogeneous project which is inevitably permeated by the rules of media coverage and market distribution (something I further examine in the Epilogue).

As I mentioned earlier, the foreign "I"/eye is an important purveyor in the commodification of "Colombian violence." In Chapter 3, I switch my focus toward such outside views provided by international travelers from Australia, Great Britain, France, and the US, who come to Colombia and report their travels back to their countries of origin. In particular, I study Ramón Chao's The Train of Ice and Fire (1994), Stephen Smith's Cocaine Train (1999), Matthew Thompson's My Colombian Death (2008), Michael Jacobs's The Robber of Memories (2012), and Tom 
Feiling's Short Walks from Bogotá (2012) as exemplary case studies of the emergence of travel books that foster Colombian "dark tourism." These travel narratives are primarily tailored for a new brand of readers who are captivated by a country of beautiful landscapes amidst the remnants of violent conflict. By analyzing these travelogues, I shed light on the economic and cultural conditions that have propelled the emergence of a global market for this genre in the case of Colombia. As my analysis shows, the buoyant travel industry and travel literature (before the COVID-19 pandemic) anchored in the Colombian condition attest to a unique combination of pure leisure, dark tourism, and humanitarian advocacy that is highly symptomatic of today's cultural market and of the commodification of travelogues for pleasure reading.

In the last two sections of the book-Chapter 4 and the Epilogue-I explore cultural production within the context of Colombia's peace process and national reconciliation efforts. As the country has opened up toward international commerce and global tourism, film production has benefitted from new accessibility to (formerly known) territories of conflict in remote rural areas of the country. Such accessibility has expanded Colombian film production and its distribution worldwide. In particular, I focus on the importance of visual touch in recent Colombian cinema as a new path toward understanding the decades-long armed conflict and articulating practices of reconciliation. To that end, I investigate the pervasiveness of haptic images and related visual devices deployed by contemporary Colombian filmmakers that trigger tactile and aural experiences on the screen, bringing to the forefront the possibility of feeling the Colombian conflict through affective visualities instead of merely seeing it. By challenging the ocular-centric scopic regime associated with realist depictions of conflict in Colombian cinema, I examine Ciro Guerra's La sombra del caminante (2004), William Vega's La sirga (2012), César Acevedo's La tierra y la sombra (2015), and Jorge Forero's Violencia (2015). These films foster communal filmic experiences that call for modes of active spectatorship informed by touch and contact with the other, privileging an affect-oriented approach to conflict and reconciliation.

In the Epilogue, I reflect briefly on Colombia's future under the moniker of "Post-Conflict," and how the latter may impact cultural production as the peace process moves along in the years to come. In closing the book, if one ever can actually close the book on "Colombian violence," I pay attention to the government's marketing and media strategies deployed during the signing ceremonies for the Peace Accords and subsequent referendum, and their implications for cultural production in light of the continued assassinations of social and community leaders in Colombia since 2016. To illustrate "Post-Conflict Colombia" in the cultural realm, I examine Doris Salcedo's art installation and media event Quebrantos [Shattered], which took place in 2019 as an act of collective remembrance for the social leaders who have perished in the last four years. This art 


\section{Introduction}

installation is paradigmatic of the ongoing links between the cultural market-along with its commodification of Colombia's violences-and the current national historical crossroads.

\section{Notes}

1 For more on comparative approaches to "drug wars" in Colombia and México, Mexico, see Cabañas's "Imagined Narcoscapes: Narcoculture and the Politics of Representation"; Aristizábal's and Martínez's "Violent Tales: Cultural Representation in Colombia and Mexico"; and Martínez-Durán's The Politics of Drug Violence.

2 I am drawing here from Forrest Hylton's Evil Hour in Colombia, David Bushnell's The Making of Modern Colombia, Geoff Simons's Colombia: A Brutal History, and the tabloid-size book Violentología (2012) by Stephen Ferry, a "coffee table" edition that comes in a protective sleeve featuring images of the Colombian conflict since the 1950s. While my focus is primarily on cultural production from the 1990s onwards and within the context of globalization, it is important to historicize the origins of violence in Colombia and the reasons for its cultural commodification in the global markets. It is also important to note that the work of violentólogos [violentogolists] draws mainly from the fields of history, sociology, and political sciences, and typically does not pay close attention to the intricacies of marketing and commodification of violence in cultural production. See, for instance, Gonzalo Sánchez and Ricardo Peñaranda's collection Pasado y presente de la violencia en Colombia, which includes essays by Germán Guzmán, Herbert Braun, Alejandro Reyes, and Saúl Franco (among others) offering a historical trajectory of violence in Colombia since the 19th century to present times.

3 Žižek establishes the two types of objective violence-systemic and symboliceach one corresponding to different modalities of structural violence, which is not clearly defined by an individual's action or by someone who can be easily identifiable. For example, the normativization (and acceptance) of poverty as a systemic problem in market-driven neoliberal economies and political regimes often results in "selective blindness" that prevents people from identifying social inequalities associated with objective violence (3-7).

4 Within this historical context, Gregory Lobo posits the term nacionismo [nationism], as an alternative formulation to live and experience a "national life" in Colombia.

5 In his analysis of the Global South, Herlinghaus suggests a reconsideration of Benjamin's take on violence in the context of global inequality, neoliberal capitalism, and the new cultural imaginary they bring about: "the original purpose of tracing a philosophy of history of violence poses further questions today [...]" given the context of "existential spaces that have been globalized at the edge of cosmopolitan freedom and civic nationhood" (Violence 3-7).

6 It is also important to note the approaches offered by recent monographs on Colombian cultural production that do not focus primarily on the global marketing and commodification of violence. These monographs, however, offer important contributions to read Colombia's cultural production, for instance, through remnants and residues (Fanta Castro's Residuos; Rueda's 
La violencia), memory and remembrance (Ospina's El rompecabezas), gender and feminist discourse (Martin's Painting), or ghostly matter and spectrality (Martínez's Ghosts; O'Bryen's Specters). Closer to my approach is Alexander Fattal's Guerrilla Marketing, which provides an insider's view into the Colombian government's use of marketing strategies to rein in FARC combatants into consumer society, which I further discuss in the Epilogue.

7 I borrow the term "culture industry" from Theodor Adorno and Mark Horkhemier's seminal essay "The Cultural Industry: Enlightenment as Mass Deception" (1944) and Adorno's revisitation in "Culture Industry Reconsidered" (1964). In the first essay, the emphasis is on the deception of the masses under capitalism's practices of cultural consumption and entertainment as a de facto elongation of the workday's productivity. In the second one, written once Nazism and its fascist propaganda machine are no longer present, the culture industry is still anchored in its anti-enlightenment character, but "the masses" appear to have gained more agency and are more aware of its practices. In the Latin America neoliberal context, I draw from some of Adorno's tenets to tackle the dynamics of today's culture industry as it relates to the circulation of capital and cultural goods as commodities.

8 I am drawing here from my previously published articles "Se vende Colombia" and "Edición local para el nuevo milenio." For a brief history of the best seller since the 1920s, see López de Abiada's essay in his collection Éxito de ventas y calidad literaria: incursiones en las teorías y prácticas del best-séller. See also Daroqui and Cróquer.

9 Throughout this book, all translations from Spanish texts are mine unless otherwise indicated. In some instances, where the original text is important for my analysis, I quote the Spanish original and then provide the English translation.

10 Restrepo and Vásquez received the Alfaguara Prize and Mendoza the Seix Barral Award, respectively, for these novels, which achieved considerable commercial success with multiple editions and international distribution. Not in vain the Alfaguara jury declares in the award certificate that Restrepo's novel offers "a kaleidoscope of modern society, centered in Colombia's complex and exasperated reality" (344), and Vásquez's novel is heralded as "a poignant reading about love and fear" (264). Likewise, Seix Barral's backcover presents Mendoza as "one of the ultimate exemplary cases of the new Colombian narrative, a literature that has distanced itself from magical realism and discovered new voices for a new reality" (Satanás). Polit Dueñas dates the emergence of sicaresca fiction (a sort of picaresca genre around the sicario figure) —and, more generally, cultural production about sicariosaround the assassination of Rodrigo Lara Bonilla in 1984 by Escobar's paid assassins. She includes Alonso Salazar's No nacimos pa' semilla as a seminal text of this genre, along with La virgen de los sicarios and Víctor Gaviria's film Rodrigo D ("Sicarios" 114).

11 This type of maquila dynamics is key in the production and distribution of the publishing house Alfaguara, whose website openly displays the transnational logic to which Yúdice alludes, as can be attested on the home page of Alfaguara Global and its 16 sites on both sides of the Atlantic: Spain, US, Puerto Rico, Mexico, Dominican Republic, Costa Rica, Colombia, Venezuela, Ecuador, Peru, Bolivia, Brazil, Paraguay, Chile, Uruguay, and Argentina (www.alfaguara.com). 


\section{Introduction}

12 In The Expediency of Culture, Yúdice further explores culture as part of the economic development that is designed to produce a new cultural economy: "culture is increasingly wielded as a resource for both socio-political and economic amelioration" (9).

13 It is important to note that the Spanish translation of Appadurai's Modernity at Large (1996) — which was published by Fondo de Cultura Económica in 2001 under the title La modernidad desbordada and included a reflective prologue by Hugo Achugar-greatly contributed to Latin American debates about the role of localities within the larger global frame of reference emerging from neoliberalism.

14 Martínez-Durán argues that drug violence took hold in Medellín due to a "perfect storm" between 1984 and 1993 that brought together the fragmented State, the competitive criminal market, and the outsourcing of violence to youth gangs (111). This historical background and assessment is rarely present in the "imagined" representations of Medellín that we see in global cultural production. 


\section{Narco-Stories Globalized Pablo Escobar and Excess Consumption}

Stories about the life and times of Pablo Escobar (1949-1993)—the infamous drug cartel leader and popular folk hero-are a perfect example of how Colombian cultural products have been bought and sold by publishing and media conglomerates. More often than not, stories about drug-related violence in Colombia provide global audiences with the kind of Latin American dark exoticism that has now long been embraced and promoted by global publishing and media outlets. Such accounts foreground the historical value of personal experiences about the Colombian condition as they claim to offer international audiences a tighter connection between those who narrate stories of violence and displacement and those who actually suffer them first-hand. But, in so doing, they also perpetuate a dire outlook for the Colombian nation and the precarious nature of its irreparable violent condition, thus reinforcing a certain level of addiction to all bad things Colombian on the part of readers, critics, and media outlets. As such, violent drug-related scenarios emerging from Colombia are easily commodified in best-selling fiction, film and TV, and art, and successfully marketed in North America and Europe precisely because they provide international audiences with a sense of history, justice, and false proximity between them and localized marginal subjects.

Narco-stories, which I broadly define as storytelling about incessant violence in a lawless society ruled by paid assassins (sicarios/as) and drug cartels, have become one of the most profitable (and widely available) commodities in such global cultural markets. Examples can be found in large variety of cultural products that construct through words or images (as the case may be) stories about the drug trade, ranging over best-selling Colombian fiction (e.g., novels by Fernando Vallejo, Jorge Franco, Laura Restrepo, Juan Gabriel Vásquez), Hollywood films and television series (e.g., Netflix's Narcos), and art (e.g., Fernando Botero), as well as other forms of mass popular culture. These have been encapsulated, as Aldona Pobutsky reminds us, under the umbrella term narco-cultura-a cultural expression of drug trafficking aesthetics and "narco lifestyles in television, literature, music, architecture, language, fashion, the female beauty ideal, and social rituals, including those associated with death" that has

DOI: $10.4324 / 9781003195702-2$ 
captured global audiences' preoccupations with "mass commodities, excess, and instant gratification" (Narcoculture 3).

It is fed, for example, by the visual and artistic representations of Pablo Escobar that began to emerge since his death on December 2, 1993. Hunted down and shot in Medellín by a special group of the Colombian police and military (thanks to technological and intelligence support from the US), the photographs of Escobar's killing are both a gruesome spectacle and an incredibly rich source from which writers, artists, and filmmakers have drawn their creations. ${ }^{1}$ In the photographs it is particularly disturbing to see the captors' joyfulness as they pose in front of the camera with Escobar's obese corpse turned into the coveted trophy of a global manhunt. Escobar's bloodied dead body lies inert on a rooftop near his hideaway in Medellín while the army's special forces smile to the camera in celebration of the hunted prey. This watershed moment for Colombia's history marks the end of Escobar's reign over the global drug trade. Surely, authorities needed to show Escobar's body to the world (not unlike what had happened many years before with Che Guevara's corpse in Bolivia) as a tangible proof that Colombia's public enemy number one was forever gone. But that was not the end of Escobar in the cultural field, since his demise began his legacy in national and global imaginaries, quite the contrary. A proliferation of cultural products often designed for global consumption revived (as it were) the controversial drug lord as both a ruthless criminal and a benefactor for the poor who used his fortune to build homes and soccer fields. ${ }^{2}$

Escobar's criminality has been captured visually in the artworks of Fernando Botero and local muralists from Medellín. Botero's memorable narco-paintings of the late 1990s, such as Death of Pablo Escobar, Autobomba, and Massacre in a Better Corner, enhance the druglord's legacy and iconic status. Similarly, James Mollison's The Memory of Pablo Escobar - a photographic memoir of the drug lord through thousands of visual artifacts-features an extensive collection of kitschy art displayed in murals and paintings by local artists whose works try to capture Escobar's double life: that is, the world's most-wanted criminal and the revered modern-day Robin Hood that helped the lower classes. One of the most telling examples in Mollison's book is Hernando Orozco's oil canvas, in which Escobar's hands, solidly grounded, reach out into the slums now connected through a wooden bridge that leads to a new soccer field and housing complex provided by the opportune philanthropist. Saintly representations of Escobar appear, for instance, in Germán Arrubla's painting Heroes and Anti-Heroes where the drug baron is placed in an altar next to none other than Diana, Princess of Wales, as reproduced in the images published in Mollison's book (1820). But it is perhaps Botero's iconic painting Death of Pablo Escobar that sums up quite graphically the imprint of Pablo Escobar's legacy in Colombian cultural production and its repercussions for our global understanding of narcoculture. The painting shows a gigantic Escobar 
being showered with bullets over the tiny rooftops of Medellín while in the background there is an anticipation of serenity from the perfectly aligned abode homes and the greenery of the mountains. The narco-story told in this painting contrasts sharply with the gruesome photographs of the hunting down of Escobar by Colombia's special forces that circulated as proof of his death, and, by extension, of his grip on the global drug trade (Figure 1.1).

Botero's depiction of the drug lord's gigantic body is in sharp contrast with the miniaturization of Medellín in the background. At the moment of his death he is standing large, in excess, dodging many of the bullets targeting his body. Despite having been hit in the forehead and abdomen, the drug lord (magically) remains combative, holding up a gun on his right hand in a final act of defiance while remaining literally on top and ready to combat the final assault against his life and continue to reign in the drug trade. For Héctor Hoyos, in this painting "Botero renders his subject in the style of a grandiose, larger-than-life kingpin, annoyed at the insect-like bullets that bring him down" (132). Through this humorous and excessive portrayal, Botero actually alters and inverts the positionality

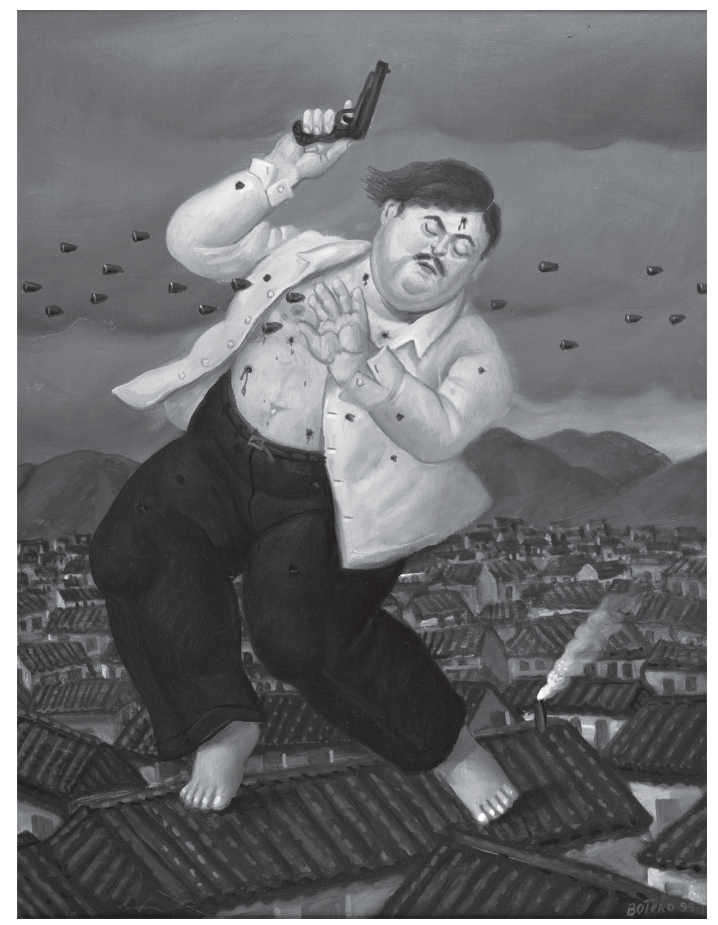

Figure 1.1 Death of Pablo Escobar (1999), oil painting by Fernando Botero $(50 \mathrm{~cm}$ x $38 \mathrm{~cm})$. Museo de Antioquia, Permanent Collection. 


\section{Narco-Stories Globalized}

and composition that we see in the photographs of Escobar's killing, where the drug lord is gunned down and lying prone on the rooftop for the amusement of the army's special forces and onlookers. Likewise, Botero's painting provides us with a powerful composition that illustrates the durability of Escobar's imprint onto the national imaginary six years after his death-a watershed moment that is almost impossible for Colombians to ignore, and, in particular, for cultural producers who keep on returning to this iconic moment of collective historical remembrance that defines the landscape of Colombian narco-stories.

Escobar's demise (and the impending sense that he was no longer a threat for those who dare represent him in a negative light) became the catalyst for the proliferation and consumption of narco-stories in Colombia and beyond-in particular, those taking place in Medellín's slums (comunas) and exploiting sexual desire, poverty, drugs, and desperation. Through the gripping visuals of Escobar's death, international audiences were made to feel more aware of Colombia's harsh realities, reassured in their knowledge, and "closer" to the struggles facing its marginalized communities. Such proximity and presumed familiarity reinforce the idea of "Colombia, the violent nation" overtaken by drug trafficking and suffering from chronic violence. Interestingly, the literary field has embraced Pablo Escobar as the emerging figure that informs much of the Colombian cultural production for the global market while other actors in the nation's violent history, such as the FARC and ELN guerrillas, have not quite made it to the global cultural market as the kingpin's iconic legacy has achieved.

But to understand the surge of narco-stories in contemporary Colombian cultural production, it is important to keep in mind the appropriation of dirty realism that became prevalent in the literary and cultural field of the 1990s and onwards (as discussed in this book's introduction). Indeed, the commodification of dirty realism in the global market shaped the imprint of narco-culture that originates in and feeds on Pablo Escobar's life and death. My main focus in this chapter is not to reconstruct the myriad representations of Escobar and how these may vary in historical accuracy or truth (if that is ever possible when examining narco-trafficking). Instead, I move away from reconstructing the capo's life as the world's most notorious kingpin in the 1980s and 1990s and turn to cultural production. Thus, I explore the role of Escobar in narco-storytelling as a global cultural phenomenon that precisely draws on the economic accumulation and excess that is characteristic of the illicit drug trade Escobar himself created. Obviously, it is hard to equate the profits from a global commodity like cocaine with those from cultural commodities such as narco-stories, but it is reasonable to propose that the commodification and distribution processes are not really that far apart-particularly when the global culture industry has had no qualms about appropriating such excess and economic accumulation in their guilt-free efforts to promote narco-stories in the international cultural 
market: "narconovelas," Héctor Hoyos writes in Beyond Bolaño: The Latin American Global Novel, "are primordially about power and accumulation, about fabulously successful capitalists who, perhaps paradoxically, have no place in the established capitalist world order" (154).

In this regard, terms like narco-capitalism or narco-accumulation are very useful to understand the market's logic behind Escobar's cocaine trade, which originated in the cultivation of coca leaves in the rural enclaves of Latin America (e.g., Peru, Bolivia, Colombia) and moved up the ladder quickly into local economies and onto international money laundering thanks to transnational laissez-faire consumer capitalism characteristic of the neoliberal economies burgeoning in 1990's Latin America. Gareth Williams illuminates us on this point when he affirms that

narco-accumulation is just one more name for the contemporary will to power of capitalism, in which capital projects itself, as always, in two directions simultaneously: (1) toward the absolutization of commodity and surplus value; and (2) toward the minimization [...] of the value of labor.

As a result, narco-accumulation fosters the movement of commodities such as "drugs, guns, and bodies" (111) with the State's tacit approval, without any legal intervention, and, in many cases, with the cooperation of rogue elements within the State's apparatus. Relating to this idea, Hermann Herlinghaus sees in Escobar a confluence of late capitalism with a rupture in its own "geopolitical rules" that allows for a liberal and universal democratic model, in which violence and neoliberalism go hand in hand to disregard "the authority of the super-state" (Narco-epics 95-97; 107).

Narco-stories partake in this effort as they often promote and engage in a culture of deregulated capitalist excess, or more precisely, in excess consumption, as illustrated by lavish mansions, flamboyant lifestyles, haciendas that resemble theme-parks and zoos, or trophy women "beautified" with gallons of silicone. Unnecessary expenditure rules the excess consumption in the narco world, or at least, in the narco world being portrayed in cultural production and being consumed by readers and filmgoers worldwide. Michael Taussig aptly describes this type of expenditure affiliated with the narco world as indulging in dépensea concept coined by Georges Bataille to refer to unproductive spending or "toomuchness," whereby consumption exceeds what would typically be regarded as normal or sufficient consumption. The hilarious example Taussig provides to illustrate his point takes us to one of Escobar's ringleaders, José Gonzalo Rodríguez Gacha, whose toilet paper at home was embossed with his initials in real gold: "That's a lot of gold down the chute when you consider how many initials he had. JGRG" (Beauty 11). Examples like these are illustrative of what Taussig sees as today's 
economy of delirious consumption-something that Pablo Escobar and his ilk engaged in on a daily basis and is now being shared as part of a global culture of "excess consumption." 3

Consumption is irremediably linked to a global economy that is anchored in (let's call it) "instant capitalism," in which monetary transactions and purchases are just a click away from handheld devices. This is also true for cultural commodities and, in the case of Latin America, it is often based on the extraction of peripheral localities that can easily circulate worldwide and be monetized. In this sense, Hoyos argues that the emergence of a global Latin American novel-to which I would add globalized narco-stories - coincides with international events such as the Fall of the Berlin Wall and the Tiananmen Square massacre in 1989 when supra-national spaces and a new understanding of globality "from the ground up" begin to take shape in earnest. From this historical juncture (at the height of Escobar's grip on the drug trade), heretofore peripheral localities, such as the ones originating in Latin American enclaves like Medellín, cannot be ignored in the transnational canon of world literature (5-6). While marginal characters from Latin America's periphery take center stage in such transnational canon, so does their monetization through cultural commodification, as is the case with Colombia's sicarios and other marginal characters of the drug trade.

With this transnational and global economic context in mind, in this chapter I situate Colombian narco-stories in the literary field through global novels such as Fernando Vallejo's La virgen de los sicarios (1994) and Juan Gabriel Vásquez's El ruido de las cosas al caer (2011), which I see as exemplary cases of Pablo Escobar's cultural, political, and socioeconomic repercussions for Colombia's national identity worldwide. Second, I examine the appropriation of narco-stories as a global literary genre that has been commodified beyond Colombia's confines as in the case of Vietnamese-Australian writer Nam Le's The Boat (2008). And third, I turn to film and television to explore how media outlets (HBO, Caracol) have appropriated narco-stories for popular consumption. In particular, I analyze Pecados de mi padre (2009) and Entourage (2009) as two distinct representational models of Escobar's cultural and political legacy, and the proliferation of Colombian narco-soap operas and their penchant for (and promotion) of excess consumption through global media.

\section{Locating Narco-Stories in Fernando Vallejo and Juan Gabriel Vásquez}

Fernando Vallejo's publishing success in recent Colombian narrative is particularly paradigmatic of the global publishing trend that seeks out specific marginal localities (e.g., Medellín) to be turned into cultural commodities. He is also a paradigmatic case of a new kind of "superstar author" in the global market, whose success has to do with the recurrent 
themes of violence and human despair in his works, the cinematic adaptation of his writings, his innovative narrative technique, and also the literary persona created by Vallejo himself: a homosexual who (provocatively) claims to be a pederast, a renegade of the Colombian intelligentsia, an outspoken critic of sacred cows like Gabriel García Márquez, and a fierce enemy of the political elite in Colombia. ${ }^{4}$

Considered a pariah by a segment of Colombia's cultural elite due to his insistence in portraying an apocalyptic Colombia, full of corpses and murderers, Vallejo attempts in his novels to (re)create a collective memory that incorporates those corpses as an integral part of his personal memory. According to Javier Murillo, author of the prologue for El río del tiempo, a collection of Vallejo's five autobiographical novels, "memory tends to become a big and embarrassing object that grows, irregular and deformed, every day. Even more so in Colombia, where it provokes nightmares of acephalous monsters" (7). These headless monsters appear in the settings of Vallejo's work-his grandparents' estate (Santa Anita) and the house in Medellín-always intertwining with the memory of his agonic characters. ${ }^{5}$ Vallejo's characters delve into a longing for home to ignore violence, and they are often unable to explain the social malaise that surrounds them.

For this reason, despite his caustic and mordant self-depiction as a renegade provocateur, Vallejo indulges in a longing for his childhood, youth, and the family home in a better time, alien to the harsh reality of today's Colombia. In El río del tiempo there is, as Daniel Balderston has pointed out, a "plural conception of the subject and the mode of autobiographical fiction that characterize Proust's writing," although in the case of Vallejo we face "irreverent autobiographies" with a self-portrait of the author that is "not particularly flattering" (157). ${ }^{6}$ Thus, Vallejo's novels question all totalizing notions of the enunciating subject and lead to a dislocation, to a non-place, which is key to understanding the literary trajectory of the writer himself. He, as the displaced subject in his novels, abandons his native Colombia to study cinema in Rome, and, after living in New York, takes up permanent residency and citizenship in Mexico, from where he writes most of his novels and diatribes against Colombia's political elite and violence. It is therefore not difficult to associate these displacements of the author with those experienced by his characters and even by his literary and cinematographic production.

It is my contention that the conjunction of memory and displacement gives us the key for the literary success of Vallejo's work, as well as for that of other Colombian authors in the global market (e.g., Jorge Franco, Laura Restrepo, Juan Gabriel Vásquez). As Álvaro Bernal points out, Vallejo represents the "trans-territorialized intellectual" (63) as a result of his nomadism through what Bernal denominates an "unfinished" Latin American city, "a metropolis made of patches from a picturesque, postmodern, multi-temporal, and hybrid village which produces multiple intercultural spaces" (65). These spaces, these marginal localities, sell 
well in the literary market insofar as they respond to the "transnational methodological setting" ("La reconfiguración" 642), an ingenious label with which Yúdice encapsulates the commercialization of such spaces at a global level. In addition to this, it must be noted that Colombian contemporary literature, as María Helena Rueda reminds us, is structured around "writings of displacement" that emerge as a result of voluntary and forced movements such as violence, kidnapping, and uprooting, which evince the collapse of the "I" of the speaking subject, who stands as an inhabitant of a non-place ("Escrituras" 391-395).

For example, the narrator in La virgen de los sicarios, Fernando, is aware of the impossibility to produce a linear and concatenated narrative because "Colombia is out of joint. [...] [It is] the most criminal country on earth, and Medellín, the capital of hatred" (9-12). His return to Medellín produces a break in his pleasant childhood memories (which followed a certain logical order), making it impossible for him to articulate a wholesome linear narrative in light of the chaos that dominates the city and the country, which has become "a serpentarium" (49). The narrator is fully aware of that impossibility: "But I am anticipating, breaking the chronological order and introducing disorder" (42). Obviously enough, the narrator finds himself embedded in the disorder that surrounds him, in the senseless killings, and in a transformed Medellín, dominated by the chaos that he struggles to narrate. This insistence in reconstructing an ordered logic for present events that surround the characters is one of the most distinctive features of the new Colombian narrative. The act of reconstructing there where only disorder prevails leads narrators to ask themselves how to narrate order in a society where every notion of the State or the law established from above is challenged, how to narrate order when a nation has been in disarray due to decades under Escobar's and the drug trade's violence. This kind of narratorial commentary about the need to order, to search for a logical sequence of the events, is almost a singsong in La virgen de los sicarios, a novel that can easily be read as a prime example of Colombian narco-stories. ${ }^{7}$

It is revealing, in this regard, that the documentary La desazón suprema: retrato incesante de Fernando Vallejo (2003), directed by Luis Ospina, opens with the "Forum of Ibero-American Writers" taking place in Bogotá in 2000, where Vallejo articulates a fierce critique of Colombia's corrupt politicians themselves. This elite, according to him, has destroyed the country and forced more than three million nationals into exile. His speech is illustrated by a sequence of graphic scenes that show headless and armless bodies, wounded by bullets and in a state of putrefaction, derelict houses that have been burned, along with the images of a Colombian cartel, the guerillas, and the political elite itself. These harsh images of social violence are synthesized by Vallejo himself, who, echoing the short story by Esteban Echeverría's "El matadero," calls his country "a slaughterhouse where we came to die," and from which people must escape: "The destiny of the Colombians of today"-Vallejo adds-"is 
to leave, provided, of course, that we don't get killed before that" ( $\mathrm{La}$ desazón). In contrast with the shocking images of dismembered bodies, the documentary (which, ultimately, is a flattering homage to Vallejo's literary persona and work) then focuses on the author's childhood house to offer a homecoming and the retrieval of family memory. This retrieval is ignited by the display of some Super 8 film reels recovered from a trunk in Vallejo's home. While the family is immersed in the remembrance of better, calmer times, in which street violence and the so-called "national disaster" are not present, a voice-over narrates an excerpt from the novel La virgen de los sicarios:

me iba retrocediendo a mi infancia hasta que volvía a ser niño y a salir el sol, y me veía abajo por esa carretera una tarde, corriendo con mis hermanos [...] Unas cuadras después pasamos frente a Santa Anita, la finca de mi infancia, de mis abuelos, de la que no quedaba nada. Nada pero nada nada: ni la casa ni la barranca donde se alzaba.

I would gradually go back to my childhood until I became a boy and the sun would rise again, and I would see myself on that road one afternoon, running with my siblings. [...] Some blocks ahead we passed by Santa Anita, the land of my childhood, my grandparents' estate, of which nothing remained. Nothing, absolutely nothing: neither the house nor the slope where it used to stand.

Nothing, nothing-Vallejo insists_- "nothing remains" of that place from childhood, of that memory that has been ravished. The documentary shows the writer himself searching for those places of remembrance, now completely erased and almost unrecognizable amid the new constructions. This is, in Vallejo's words, "one additional violence" in his nostalgic drift, in his attempt to retrieve the family memory, already inevitably reviled by the passage of time, by his self-imposed exile, and by the physical disappearance of idealized locations like Santa Anita that are so present in his work.

This constant interplay between memory and the harsh reality of the present is reiterated at the end of the documentary: an image of Vallejo's face cut into four quadrangular sections serves as the background for the author's last intervention. As he proceeds with his final diatribe against the human race, the quadrangular sections begin to uncover new features of Vallejo's face until it is presented as a whole. The fragmentation of his face emulates the dislocation of his characters and narrators. It is therefore not surprising that the last image of the documentary shows Vallejo closing the trunk where the Super 8 family films were kept and then taking a walk through Mexico City to loiter and get lost in his memories.

The longing for the physical places of childhood is complemented in the documentary with a section about the tragic death of Darío, Vallejo's 


\section{0}

brother, the main character of the novel El desbarrancadero (2001), which narrates the almost simultaneous death of two relatives of the author: his 82-year-old father and Darío. The body of the dying brother, who suffers from a fierce case of AIDS that consumes him, is without a doubt the lens that the narrator privileges. The descriptions of AIDS patients as "translucid ghosts moved by the light that animates butterflies" (8) give way to the scientific (and perhaps more realistic) tone of Darío's decaying body: "the candidiasis that follows immuno-suppression had ulcerated Darío's mouth and even prevented him from swallowing the serum that I would prepare for him, mixed with diluted antimycotics" (172). The only resolution, given the medical failure to heal his brother's body, is Darío's wandering through the innermost recesses of his memory, which is also the writer's family memory:

Enflaquecido, extenuado, estuporoso, los ojos hundidos, la piel marchita, se pasaba las horas y las horas en el jardín hojeando el viejo álbum de fotos y hablando, hablando, hablando, delirando, mezclando historias de tiempos idos más venturosos.

Emaciated, exhausted, logy, with sunken eyes and withered skin, he spent hours and hours in the garden browsing through the old photo album and speaking, speaking, speaking, raving, mixing stories from more fortunate bygone times.

(El desbarrancadero 172)

Passages such as these evince Vallejo's attempt to situate memory as an antidote against the harsh personal reality, as an escape from the dire conditions in the localities of the present time. In the case of Darío, while he experiences physical decay, the agonic memory prevails- "speaking, speaking, speaking, raving"-in an effort to reconstruct a whole that is negated by physical deterioration and, therefore, by the decay of the subject himself. Perhaps in an attempt to recover Darío's already absent body, the documentary La desazón suprema illustrates the section on his death with a series of charcoal engravings depicting beautiful naked bodies and erect penises, establishing a contrast between these images and the descriptions of Darío's body in the novel. His body is only redeemedamidst the continuous diarrhea, the multiple infections, and his general decay-in the family memories, illustrated as they are by a photograph of Darío and Fernando on the novel's cover. That picture is the symbol of a brotherly and almost corporeal communion, as the narrator himself concludes toward the end of the novel:

Habían llovido los años sobre esa foto y ahora mi hermano se está muriendo [...] Lo mejor que le podía pasar a él era que se muriera. Lo mejor que me pudiera pasar a mí era que él siguiera viviendo. No concebía la posibilidad de vivir sin él. 
The years of rain had poured over that photo and now my brother is dying [...] The best that could happen to him was dying. The best that could happen to me was that he could live. I couldn't imagine the possibility of living without him.

(El desbarrancadero 186)

The writer's fixation on his brother's body (which ultimately operates through the comparison between a healthy and a decaying body) develops into a final corporal union when the narrator announces that Darío's death has also produced his own: "And at that moment, with the phone in my hand, I died. Colombia is a lucky country. It has a unique writer. One who writes dead" (193). This "dead writer" is the main character of his next novel, La Rambla paralela (2002). He is Vallejo's alter ego, who travels to Barcelona from Mexico City to attend a book fair where certain (unnamed) Colombian authors are being promoted. Hovering between life and death at a Barcelona hotel after apparently suffering a heart attack, and plunged into total agony, the writer tries to call his native Colombia to contact his family at the Santa Anita estate. But he's unable to exit the hotel and, during the hours of his cardiac arrest (and probably already dead since the first pages of the novel), he will wander through the Ramblas as a living dead, retrieving the image that the author had already used in La virgen and extrapolating it in an apocalyptic vision of his native Colombia, which crosses borders and follows him to Europe:

La Rambla a esas horas hervía de gente. Gente y más gente, todos desconocidos, todos extraños, un desfile de fantasmas sin parar [...] ¡Ésta es la Rambla de los fantasmas! Y los vio opalinos, translúcidos. Ahí iban tan orondos como si estuvieran vivos [...] Se habían convertido en espantos, sombras, visiones, que iban dejando flecos y jirones al avanzar [...] y mientras uno se va tomando su copa va observando el desfile de los cadáveres.

The Rambla boiled with people at that time. People and more people, all unknown, all strange, an incessant parade of ghosts. [...] This is the Rambla of the ghosts! And he saw them opaline, translucid. There they walked so carelessly, as if they were alive. [...] They had become specters, shadows, visions, which left behind them fringes and shreds as they moved on [...] and, while you drink your glass, you can see the parade of corpses.

(La Ramba paralela 27-28)

The metaphor of the rambla (a broad street built on a dry river-bed) as the location of city-wandering extends, as the novel progresses, into a transatlantic rambla where the subject stands, no longer a man of flesh and blood but rather a specter who wanders by that imagined rambla that connects Europe with the Americas, retaining the renegade personality of 
Vallejo himself: "He had become spectral, transubstantial, ubiquitous, but not for that reason any less foul-mouthed and blasphemous" (60). ${ }^{8}$ Vallejo's attempt to trans-nationalize his narrative in La Rambla paralela leads also to a reflection about the Hispanic literary publishing market, nowadays dominated, as we have seen, by media conglomerates.

In this sense, his novel is also a reflection about what sells (and what doesn't) in that market-his novel being in itself an example of a writing of displacement narrated as the personal ordeal of his agony in Mexico, Colombia, and Spain. Some brief comments made by the narrator about the publishing industry amidst the Moll de la Fusta Book Fair in Barcelona- "the books that sold the most at that fair were the Colombian ones" (La Rambla 32) and "the books of Planeta Colombia are made of sugarcane bagasse, they are shit" (La Rambla 62)—illustrate how Vallejo's alter ego is fully aware of the literary field and publishing market. In the fictional fair, recent Colombian narrative is subject to the "search for bestsellers" that media conglomerates seek even if it is a book from [the publishing firm] Planeta Colombia that falls apart once opened. It doesn't matter if the physical object (the book) crumbles in our hands. After all, it is a Colombian book about Colombia, and this is consistent with the kind of novel proposed by Vallejo, with its visual harshness, its agonic memory, and its grim reflection on society. No doubt, authors like Vallejo and his brethren share the use of marginality and cultural difference in pocket editions of their works that may tear apart in our hands-something very apropos of the publishing industry's dynamics to reduce cost at the expense of local economies for larger profits in the global market.

Within such dynamics, Hoyos understands Vallejo's fiction as exemplary of the "global novel," as belonging to or having "world literary standing," and, in the case of La virgen de los sicarios, as consolidating "both the world and Latin America as [...] chambers of resonance" (67). Narco-stories, then, are to be regarded as world literature since "they transcend borders and impact societies in numerous ways" and challenge "expectations about cultural flows" that emanate from the periphery (Hoyos 128). Furthermore, they are illustrative of an important tension between local and global cultural (and economic) forces that are bound to upend the hegemonic model by which "Latin America provides the raw literary materials and metropolitan academia does the criticism" (154).

Such local and global tensions are crucial to understand the international success of Juan Gabriel Vásquez's bestseller novel El ruido de las cosas al caer (2011). Published seven years after Vallejo's La virgen and eight years after Escobar's death, Vásquez's novel is a salient example of the globalization of Colombian narco-stories and of the cultural flows from the periphery that transcend borders. ${ }^{9}$ In this novel, Vásquez reconstructs (for the world) the memory of Ricardo Laverde, a pioneer pilot who worked for Escobar in the early years of the cocaine trade, who befriends the novel's narrator, Antonio Yammara, in a somewhat 
rundown billiard room in Bogotá in 1996. Shortly after their acquaintance, Yammara witnesses Laverde's killing in the street, which triggers an investigative quest on Yammara's part to reconstruct the narco-pilot's enigmatic past and his relationship with Escobar and the cocaine trade of the 1980 s and 1990s.

The novel's opening reenacts a real-life episode linked to Escobar's legacy and his infamous Hacienda Nápoles-a massive farm turned into an amusement park and zoo where the drug lord collected exotic animals from all over the world. Among these were four hippopotamuses brought from Africa, who freely reproduced in the favorable conditions of the Magdalena River and easily adjusted to the temperate climate of the region. As a result, Colombia has now a growing population of about eighty hippos roaming freely in the Magdalena Medio area. Since hippos are not a native species to Latin America, this initiative from the entrepreneurial (now turned "environmentalist") Escobar proved to be a case of dépense gone awry and of excess consumption that has had an irreparable impact on the flora and fauna of that region since the 1980s. It was 2009 when one of Escobar's hippopotamuses on the loose threatened the local population (particularly, fishermen and farmers), and was shot to death by the army in a manner that was eerily similar to the gruesome hunting down of Escobar himself (photographs of the dead hippo included). This real event is the catalyst for the novel's opening and for the historical reconstruction and remembrance of Escobar, who remains in the national imaginary as a monster-like figure, a beast like the hippo on the loose:

El primero de los hipopótamos, un macho del color de las perlas negras y tonelada de media de peso cayó muerto a mediados de 2009 [...] Los francotiradores que lo alcanzaron le dispararon un tiro a la cabeza y otro al corazón [...] posaron con el cuerpo muerto, la gran mole oscura y rugosa, un meteorito recién caído [...] y de inmediato comenzaron a descuartizarlo.

The first of the hippos, a male the color of black pearls and of a half-ton weight, fell dead in mid-2009 [...] The snipers who hit him managed to shoot him in the head and in the heart [...] they posed with the dead body, the great dark and rough mass, a recently fallen meteorite $[\ldots]$ and they immediately began to dismember it.

(Vásquez, El ruido 13)

The comparison between the hunting of the drug lord in 1993 and the hippo in 2009 evinces Escobar's imprint on Colombia's national imaginary and the conflictive relationship between military forces and those deemed "enemies of the State." As Rory O'Bryen suggests, the slain hippopotamus can be seen "not only a symbol of environmental damage and the drug-traffic's transformation of Colombia's landscape, but also as symptom of the devaluation of life" in general and in the 
Magdalena's ecosystem, as that of a "foreign body" that needs to be killed in order to protect human life ("Affect" 240-241). ${ }^{10}$ What interests me about the novel's opening is that it anticipates a narcostory about violence and memory that conflates "the magical" (hippopotamuses roaming in the remote areas of Colombia) and "the dirty" (the great dark and rough mass) for global consumption. Furthermore, Vásquez's narrator is fully aware of these two dominant modalities as Yammara is constantly making references to García Márquez's brand of magical realism with an inordinate amount of intertextual dialogue with the opening sentence of Cien años de soledad ("Many years later, as he faced the firing squad ..."): "Muchos años después, recordando ese día aciago" (El ruido 112) [many years later, remembering that awful day]; "Y muchos años después también él, Ricardo Laverde, contaría el accidente" [and many years later he, Ricardo Laverde, would also relate the accident] (El ruido 154). This literary borrowing from the Latin American Boom's most celebrated author (Gabriel García Márquez) reinforces the novel's status as a "Latin American global novel" (Hoyos) that blends the new and old ways of fictionalizing Colombia for the international literary market. ${ }^{11}$

Another important aspect in Vásquez's novel is the resurgence of Medellín as a locality attached to the memory of Escobar and the drug trade, and certainly to the narrator's memory. Similar to what is seen in Vallejo, Vázquez capitalizes on memory to bring back to life the legacy left behind by Escobar. The hippopotamus, the beast on the loose, in effect, activates Yammara's memory and pushes the narrator to selfreflect on the historical reconstruction of Laverde's narco-story: "En mi memoria, los meses que siguieron son una época de grandes miedos y pequeñas incomodidades" [In my memory, the months that followed are a time of great fear and little discomfort] (54). It is through aural documentation-e.g., cassette tapes, noises-that the novel rescues a forgotten episode of Escobar's life and time in accordance with the expectation of the global literary market, that is, by producing a narrative based on violent events and historical memory triggered by the "sound of things falling": "Es el ruido de las cosas al caer desde la altura [...] esos ruidos formaban parte de mi memoria auditiva" [It is the noise of things falling from heights $(. .$.$) these noises were part of my aural memory] (83-$ 84). These "falling things" - the killed hippo dropping to the ground, the slain body of Leverde collapsing on the street, and the Avianca airplane bombed by Escobar plummeting from the sky—signpost Vásquez's narco-story and trigger the narrator's memory and investigation of noises from the past. ${ }^{12}$ Escobar's imprint on contemporary Colombia proposed by Vásquez-through the tracing of noise, sounds, and aural documentation (e.g., cassette recordings) - espouses global publishing trends that seek out multi-faceted (in this case, multi-sensorial) approaches to history reconstruction through personalized memories. Thus, by relocated narcostorytelling through such personal memories, El ruido de las cosas al caer 
partakes in the "memory boom" that literary publishing has espoused and commodified for global consumption (as I will discuss in Chapter 2).

\section{Nam Le’s “Cartagena”: A Global Narco-Story}

Why did an Australian author of Vietnamese origin who writes stories about local and universal crimes become a publishing sensation in 2008? And why did he write a narco-story about Colombia's sicarios? With these opening questions, I would like to reflect on Nam Le's debut work, The Boat, a collection of short stories inspired by a series of local conflicts easily recognizable by a wide spectrum of readers. Nam Le-a refugee who fled with his family from the communist regime in Vietnam-narrates uprooting through a vast map of localities in places as distant as Iran, Japan, and Colombia, promoting a type of literature that clearly feeds from focal points of conflict and, in some cases, of atrocities. Endowing his stories with ethical justice, Le departs from grotesque descriptions related to dirty realism and seeks, instead, a certain degree of lyrical composition in his recreations of the daily lives of displaced or dispossessed characters (victims, criminals, and people living on the margins of society). ${ }^{13}$

The release of The Boat makes evident that the stories created by Nam Le fit entirely into a publishing trend that leads to perpetuating crime as a profitable and effective topos in the cultural market: promoting best sellers that exploit the criminality inherent in certain localities, highlighting its global ramifications to sell crime as a product of cultural consumption. The availability of The Boat in both digital and audio formats, as well as Nam Le's website, is designed to achieve a wide international distribution of narratives that, as announced by the author's own website, "explore a vast geographical landscape."

From his native Vietnam to his adopted country, Australia, through Tehran, Hiroshima, Medellín, and Cartagena (Colombia), Le's characters often illustrate the human condition of the dispossessed and uprooted. However, despite the obvious autobiographical connections between Nam Le's personal life and his fictions, The Boat has been primarily promoted not as a type of ethnic (Asian-Australian) literature but rather as an international and cosmopolitan fiction, in which the figure of the refugee is redefined as a result of new market trends that transform memory into a cultural commodity (Goellnicht 197-199). This is exemplified both in the (global) media distribution of the book and in its own self-reflective nature, displayed in the short stories "Love and Honor and Pity and Pride and Compassion and Sacrifice" and "The Boat," which appear, respectively, at the beginning and at the end of the collection. Both stories create a very interesting narrative circle, through which Nam Le first reflects on his literary work and deals with the problem of how to use the family memory of exile in his fictions ("Love and Honor"); and, finally, he creates a story that recounts the tragic journey by boat of a 
family of Vietnamese refugees ("The Boat"). In this reflexive way, Le himself weighs and exposes the ethical conflict of the writer who markets a literature on refugees and displaced people. Clearly alluding to the way in which Le himself deals with these ethical issues, "Love and Honor" stars Nam-an Iowa-based writer-who, after a period of creative idleness, is faced with an ethical decision similar to Nam Le's: whether to exploit or not the creative vein involved in narrating the memory of his family as exiles and refugees in Australia; or, rather, to continue narrating similar stories about Hiroshima or about Colombian sicarios, albeit taking some personal distance. ${ }^{14}$ All these options come to life in The Boat, a book that, in the end, confronts the opportunism that leads the real writer (Nam Le) and his fictional counterpart (the character Nam) to appropriate the so-called ethnic writing.

This "ethnic opportunism"-which is obviously in tune with the cultural consumption of marginality-comes to the forefront in the second story in the volume. Entitled "Cartagena," this narco-story is narrated by Juan Pablo Merendez, a 14-year-old sicario from Medellín, and takes place during the electoral period that led Andrés Pastrana to the presidency in 1998. It should be noted that important negotiations with the guerrillas were carried out under his government, as well as the implementation of Plan Colombia, the controversial military and financial aid package against drug trafficking designed by the Clinton administration. As Michael Taussig points out, the main feature of that policy was the direct attack against the guerrillas-and not so much against the drug traffickers-by the US. As a result, the so-called "War on Drugs" became in fact a "War for Drugs," since both guerrillas and paramilitaries used the profits from drug trafficking to fund their causes (Taussig, Diary 18$).{ }^{15}$

Amidst this climate of (political and social) crime, Nam Le explores in "Cartagena" the story of Juan Pablo-who is known in Medellín's comunas (slums) as Ron due to a notorious episode in his early adolescence, when he drank half a bottle of rum without vomiting: "I am a sicario, a hit man, an assassin"-the narrator tells us-"I have been a sicario for four months, although my agent, El Padre, says that in truth I am a soldado fighting for a cause" (Le, The Boat 37; italics in the original). ${ }^{16}$ Therefore, from the beginning of the story the narrator alludes to the militarization of Colombian society and to the intricate tangle of violence created by the army, the paramilitaries, the self-defense groups, and the guerrillas. It is against this background that "Cartagena" begins.

Immediately after, we are told that the main character, Juan Pablo, has been hiding for four days, fearing that he will be summoned before his boss, El Padre-a figure who clearly emulates El Patrón, Pablo Escobar. As it turns out, young Juan Pablo was asked to annihilate his childhood friend Hernando, who saved his life before becoming a sicario, and, due to his refusal to do so out of loyalty to his friend, he now lives in fear of fierce retaliation. While Juan Pablo awaits his almost certain death, Le's 
narrative takes us, on the one hand, toward the main character's past in the most typical sicaresca-learning style (as we see in the works by Fernando Vallejo and Jorge Franco); and, on the other hand, the narrative builds a paradise called Cartagena-a safe and imagined haven on the coast where the sicario's existence is replaced by idealized white sand beaches and blissful tranquility (29). This is what Luis, a fellow sicario older than Juan Pablo, says to the group of young criminals at the beginning of the story: "In Cartagena everything is nothing like here" (Le, The Boat 30). The description of this Caribbean town contrasts sharply with Nam Le's portrait of the harsh realities lived by the dispossessed of Medellín, where children are in the hands of basuco, glue sniffing, weapons, paramilitary groups, and guerrillas.

In "Cartagena," Nam Le successfully combines the two dominant modes of writing that have circulated most widely as illustrative of Latin American literature since the Boom years: the magical and the dirty. This fusion, which he successfully repeats throughout the story, is anticipated in the opening sentences of "Cartagena" when the narrator describes this town as an enigmatic place, a "magical" site, if you will, devoid of violence and away from the cruel reality of Medellín's comunas: "In Cartagena, Luis says, the beach is gray at dawn. He points to the barrel of his G3 when he says this, steel gray, he says. The sand is white, he says, this color, tapping his teeth" (Le, The Boat 29; italics in the original).

The opening sentences of the story anticipate, as we can see, these two imagined spaces and the duality of the main character-Juan Pablo, the good son who buys his mother a new house and often dreams of the fine sands of Cartagena's beaches (which only exist in Nam Le's fictional world); and Ron, the hitman (sicario) who cannot escape the violent comunas of Medellín (a storyline that reiterates the most classic topos of the sicaresca and of crime literature). These two imagined spaces tend to merge as Juan Pablo's story progresses and its resolution approaches. During the final meeting between Juan Pablo and his boss (El Padre), in which the young sicario will face his ultimate fate, the narrator's descriptions of Medellín are full of a sense of oppression and despair that is recurring in other Colombian narco-stories such as La virgen de los sicarios and Rosario Tijeras. ${ }^{17}$ This is not to say that Nam Le is simply imitating or repeating what these Colombian best-selling novels propose. Rather, he appropriates the topos of the sicario in order to create a universal (or perhaps globalized) narrative of crime, loyalty, and oppression, which global audiences find convincing. In this sense, Le's recreation of Medellín clearly hits the mark for the global cultural market in terms of its authenticity. At the beginning of the story, when Juan Pablo sees Medellín from his mother's house in the hills, he admires the beauty of the city landscape at night: "I see the streetlights come on, running in gridded patterns until they reach the mountainsides where they race up and spread out until all the barrios that surround the city shimmer like constellations" (Le, The Boat 41). 
However, as the ending approaches-that is, the conclusion of Juan Pablo's story and the end of his life-the city "rises over the black line of mountains, and beneath the clouds the effect is one of torchlight smothered by gray blankets" (53) to the point of suffocation when Juan Pablo meets El Padre in the last scene of the story: "The sky feels like it is sinking closer and closer to the earth" (63). The story's ending further extrapolates the sicario's feeling of deep sinking. In the room where El Padre is hiding, he first admonishes Juan Pablo for not having carried out his mission - to kill his friend Hernando-and then reveals that the sicario will not leave the room alive as two armed thugs scrutinize all his movements. What they don't know, however, is that Juan Pablo has a grenade hidden in his pocket. And when El Padre asks him where he plans to go, the young sicario responds with kindness: "I don't know, I say. Maybe Cartagena" (66). El Padre insists and asks him again about Cartagena, and finally Juan Pablo answers "no," realizing that his thumb rests "wet and slippery on the ring" of the grenade (66). It is too late to return to Medellín; Juan Pablo has decided to detonate the grenade and burst into an explosion along with El Padre and his entourage. But just as the young sicario is about to pull the grenade's ring, the memory of Cartagena returns to his mind: "the picture as I have imagined it so many times in the past" (67).

Nam Le chooses not to describe the final explosion. Instead, that potential description is replaced by the poetic depiction of Cartagena upon which the story has been building until that moment, which strikes us as atypical of most Colombian narco-stories. In this way, the recreation of the poetic memory of Luis, Juan Pablo's fellow sicario, allows the main character to put an end to the story, while providing Medellin's sicarios with an imagined escape that seems to be less violent in virtue of the idealized version of Cartagena evoked by Nam Le:

Luis is sitting on the old colonial wall and looking out toward the ocean $[. .$.$] As the sun raises, he says, you can see ten black lines$ leading into the steel gray water [...] all in harmony [as he watches] the fishermen hauling one enormous fishing net from the ocean, slowly, step by step.

(Le, The Boat 67)

The quietness of this final scene contrasts with the restlessness and hopelessness that usually characterize the endings of sicaresca stories. The reference to "metallic gray" waters in the last paragraph, however, brings us back to the beginning of the story, when Luis holds the G3 rifle and describes for the first time the beach of Cartagena to Juan Pablo and the rest of the young sicarios who make up his gang.

Although it is clear that Nam Le has read and carefully investigated the tradition of the sicaresca genre, his portrait of Colombia owes much to the incursion of another translocality-Cartagena-to explore how 
Medellín's sicarios imagine themselves beyond the geographical space of their comunas. Moreover, Le's story also invites us to consider how important the external vision of Latin America is for the fluidity and heterogeneity of the region. For Nam Le, as he stated in a radio interview, "there is no place which is not foreign to us [...] you can't really separate a place from the mind through which that place is being seen" (Raz, "Interview with Nam Le"). This clearly echoes the "imagined spaces" within the framework of globalization that mark the current human existence, in which "one man's imagined community is another man's political prison" (Appadurai 32). It is precisely this playful balance between imagination and prison that makes Nam Le's "Cartagena" an exemplary narco-story of Colombia's translocality for the global cultural market. Medellín and Cartagena have thus entered into a global frame of reference as they are imagined beyond their spatial boundaries both inside and outside of Colombia and according to a relational and contextual space-or in Appadurai's words, an "imagined neighborhood" (32) - that is without a geographical existence.

But Nam Le's portrayal of Colombia perpetuates its adherence to violence. His use of the criminal topos certainly raises all sorts of ethical questions, since it repeats the patterns that reproduce the notion of an intrinsically violent Colombia, immersed in perpetual criminality. However, as we also see in his short stories about Tehran and Hiroshima, Nam makes these scenarios poetic and suggestive, personalizing them through characters positioned against a criminal environment from which they cannot escape. The short stories "Hiroshima" and "Tehran Calling," which come one after the other in the collection, narrate, from personal experiences, the daily routine of a girl during the infamous day of the bombing in Japan and the visit of an American woman to her Iranian activist friend in Tehran. Both stories, as in "Cartagena," follow a poetic composition that is often interrupted by the grinding situation in which the main characters are immersed. For instance, we see this in the majestic description of the mountains surrounding Tehran-a beautiful setting that contrasts with the activist's arrest and presumed torture-or in the poetic hints of the young protagonist who finds herself in danger before the horrors of the imminent bombing in Hiroshima: "The ocean is a darker blue than the sky. Behind the hill is the city. We are safe here" (Le, The Boat 188).

In this sense, it could be argued that Le explores literature as a way not only to expose these scenarios of crime-understood broadly (petty, organized, against humanity)-but also to seek the poetic justice that emerges from his literary creations. Unlike other cases of social denunciation through fiction, Nam Le is rather interested in portraying moments and images that arise within a criminal framework to extract certain settings of violence and displacement typical of everyday life in specific localities. Therefore, there is no explicit and concrete denunciation of these settings that could fit within the so-called "social literature." Le 
recreates and imagines the spaces that constitute such settings and the individuals who inhabit them. Given the critical and publishing success of The Boat, it is safe to conclude that its personalized approach to crime, its definition in a recognizable (approachable) local space, and the global projection of these features have become a winning formula for a profitable cultural production of globalized narco-stories, with all the ethical issues that such success entails.

\section{Escobar as Media Entertainment: Pecados de mi padre and Entourage}

It was only a matter of time until narco-stories would leap from the literary and artistic fields into the vast and ever-expanding world of media, particularly film, television, and streaming platforms. Visual media quickly enthroned Escobar as a legendary kingpin, villain and iconic popular hero for global mass consumption. As the recent Netflix series Narcos (2015-2017) illustrates, Escobar continues to be a cash cow for media distribution networks, which have contributed to perpetuating the dire outlook of the Colombian nation and its irreparable violent condition. And, more often than not, they have ignored the relationship between those who narrate stories of violence and displacement and those who actually suffer them first-hand. For Pobutsky, "Narcos provides a somewhat false sense of cultural accuracy for a public with little exposure to Latin America" given "its simplistic take on Colombia" and painting "the country as enchanting yet corrupt beyond repair" (Narcoculture 232). This assessment is right on target (pun intended) and illustrates the reductionist media portrayals of Escobar's cultural and political legacy, which often enact Masiellos's levedad histórica as it pertains to US views on Latin America. HBO's engagement with Escobar partakes in this reductionist approach, despite the network's efforts to seek "cultural weight" on its media productions and not just being a source of popular entertainment. In this section, I precisely address these two representational modalities of the drug lord's legacy: one underscoring pop culture consumption of Escobar-the series Entourage - and the other reflecting on the suffering of Escobar's victims, the documentary Pecados de mi padre (Sins of My Father).

The series Entourage is loosely based on the life of actor Mark Walhberg (who is an executive producer for the series) and tells the personal story of an up-and-coming actor from Queens called Vincent Chase and his New York childhood posse, his entourage. In the third season of the series (2009), Colombia begins to take center stage when Chase-aided by his savvy agent, the foul-mouthed, fast-talking Ari Gold-lands the starring role in the film Medellin, a biopic about the life and times of Pablo Escobar. Medellin is intended to be Vincent Chase's leap from B-movies to a serious dramatic role that will consecrate him as one of the most promising young actors of his generation. The film had 
a price tag of 35 million dollars, which producers hoped to pay for once it premiered at the Cannes Film Festival. To promote Entourage's fourth season, HBO created the website medellin-the-film.com, which included reviews, cast, synopsis, and trailer for a movie that didn't actually exist outside the internet. The website showcased Medellin as a real, bona-fide blockbuster Hollywood film and, more importantly, as an example of the kind of Latin American stereotyping that is characteristic of the US media and entertainment industry. While the website is no longer active, HBO's trailer for Medellin can still be seen on YouTube. In it, Escobar appears as a ruthless, disheveled criminal covered in blood and surrounded by murdered bodies and explosions. This is, indeed, a run-of-the-mill biopic about Escobar's criminal life for mass popular consumption, as illustrated by the narrator setting up the film: "The year was 1989, and one thing was on everybody's mind: cocaine. And the man behind it all was Pablo Escobar. He made millions to achieve his dreams, and killed anyone who got in his way." 18

Medellin occupies much of the fourth season of Entourage, which opens with what appears to be a real documentary by a British media journalist about the making of the film that includes interviews with Vincent Chase and fictional director Billy Walsh, rehearsal scenes, as well as on-location shots in Colombia (in fact, the San Fernando Valley in California). In them, we can see what would lead the film industry to invest in a real film entitled Medellin and in a documentary about its making. A similar degree of authenticity can be observed in the scenes of the movie's premiere at Cannes, which resemble a real-life event with all the glamour that we are accustomed to see in film festivals of this nature. But the premiere of Medellin at Cannes turns out to be a complete flop and, much to the producers' and actors' chagrin, some booing is heard just as the audience begins to exit the theater before the final credits roll. Angered by their reaction, Medellin's director, the eccentric Billy Walsh, bursts out loudly "What the fuck are you French faggots doing? Show some respect for the Colombian people and watch the credits!" Finally, back in the US, the movie is poorly reviewed by Richard Roeper (in the fifth season of the series), who calls it "one of the worst films of the year." In the end, Medellin goes straight to DVD and the career of Vincent Chase is put on hold.

What interests me about Entourage's Medellin is that, through the iconic figure of Pablo Escobar, it illustrates well how the entertainment industry commodifies Latin America's harsh realities for the worldwide market. It shows that narratives about Escobar have become a perfect example of the way Colombian cultural products are now bought and sold by media conglomerates. More often than not, personalized stories about drug-related violence in Colombia demonstrate a shared interest in trafficking the personal life of Escobar, and in providing global audiences with the kind of Latin American dark exoticism now embraced and promoted by global publishing and media conglomerates. While 
it is true that Entourage aims at providing a distanced commentary of such practices, I would argue that it ultimately perpetuates-despite its tongue-in-cheek tone-well-known stereotypes about Colombia (and, by extension, Latin America) as a corrupt society ruled by drug lords and their sexy women, and powerful villains like Pablo Escobar. Lacking in Entourage's Medellin is, of course, any kind of reflection on or reference to Escobar's own political career and, more importantly, to the tight connections between drug trafficking, the guerrilla, and politicians in contemporary Colombia. What we see here is the "unbearable lightness of history" (Masiello's levedad histórica) and an insistence on spectacular cultural difference (e.g., "show some respect for the Colombian people") that are typical of mass-marketed Latin American cultural production. This trend is further emphasized by HBO's interest in manufacturing the illusion that Medellin (the film) actually exists. Another important component in the South by North market operations that are now typical of the culture industry is that $\mathrm{HBO}$ has been credited for the recent interest in Escobar biopics such as in the case of Loving Pablo (2017) or Escobar: Paradise Lost (2014).

To diversify its portfolio of narco-stories beyond the frivolous appropriation of the drug lord's legacy in Entourage, HBO cleverly invested in one of the most compelling cases of trafficking the personal around the figure of Pablo Escobar: the 2009 documentary Pecados de mi padre by Nicolás Entel. ${ }^{19}$ Produced by Red Creek and selected for competition in the Sundance Film Festival in 2010, HBO secured the US television exclusive rights for this documentary and premiered it on October 4 of that year. In contrast to Medellin's Escobar, Pecados de mi padre is clearly anchored in historical documentation and can be regarded as high-brow entertainment (and, arguably, as a documentary that does show respect for the Colombian people). It narrates the voluntary exile of Escobar's son to Argentina and his return to Colombia 12 years later to meet with two prominent political families-the Galán and the Lara Bonilla-whose patriarchs were victims of the drug violence in the 1980s and 1990s, and died as a consequence of Escobar's killing orders. The entire documentary relies on a very powerful scene, the actual face-toface meeting of the victims' families and Pablo Escobar's son, which took four years to arrange and film.

The reconciliation attempt is played for the camera, and, while the possibility of the Galán and Lara Bonilla families embracing Escobar's son is mentioned in the conversation, there is, understandably so, a tense atmosphere in the meeting room. The gruesome killings of Rodrigo Lara Bonilla (Minister of Justice in 1984) and Luis Carlos Galán (the presidential candidate for the Colombian Liberal Party in 1989) to the hands of Escobar's sicarios and the media spectacle that ensued their assassinations certainly obfuscate an easy reconciliation between the Galán, Lara Bonilla, and Escobar families (and, by extension, a national reconciliation). The confessional, self-accusatory, and forgiving tone of 
the conversation makes us wonder whether it was necessary for this first, very personal (and clearly painful) encounter to be played out in front of the camera. The documentarian and family participants agreed to this encounter and, in so doing, put their personal life at the disposal of yet another media spectacle concerning Pablo Escobar's criminal legacy. For long dead as he is, he remains ever so present in the room, as we can see in the scene. Granted, this reconciliation scene is more attuned to a television talk show than to the decidedly reductive representation of Escobar that occurs in Hollywood films. And, in that sense, it provides a historically grounded understanding of the intricate relationship between politics and narco-trafficking in Colombia.

But Pecados de mi padre is, above all, a conversation among orphans of the nation who represent the political climate that has defined contemporary Colombia for the rest of the world. It is thanks to the death of their fathers that their sons can now join forces in order to achieve reconciliation in a new political climate. In this regard, it is also worth noting that the heirs of the ill-fated justice minister and presidential candidate have run successfully for office in Bogotá's City Council and the National Senate. As elected representatives, these politicians had a lot to gainbesides their genuine interest in reconciling with the son of Escobarwith respect to their own political careers in agreeing to participate in constructing a more gentle legacy to the fierce narco-politics of the $1980 \mathrm{~s}$ and 1990s. ${ }^{20}$

The sins of the father are thus "cleansed" in front of the camera. Juan Pablo Escobar has changed his name and is now Sebastián Marroquín. $\mathrm{He}$ has rejected the patronymic relationship with his father the drug lord, and can now be forgiven and duly acknowledged as a victim of the paternal legacy. But, as Rocío Davis suggests,

the film's structure is thus complicated by the need to claim filiation before rejecting its consequences and legacy [...] although Marroquín's story involves his rejection of his father's life, the film ultimately traces his acceptance of Pablo Escobar as his father [...] which involves admitting his identity and making up, somehow, for his father's crimes.

Therefore, the process of cleansing Escobar's sins and crimes does not fully materialize, as the film proposes that Sebastián Marroquín really is Juan Pablo Escobar and that legacy cannot be completely erased. And, as it turned out years after the film, Sebastián took back his birth name, Juan Pablo Escobar Henao, and capitalized on his father's legacy by publishing the memoir Pablo Escobar, mi padre (2014) and launching the fashion line Escobar Henao inspired by his infamous father.

For their part, the sons of Luis Carlos Galán and Rodrigo Lara Bonilla continued their political careers in the Senate and City Council 
and, somehow, also capitalized on the reconciliation efforts afforded by participating in Entel's documentary. By bringing back to present times their suffering as victims of Escobar, they were again duly acknowledged as heroes of the nation and as qualified interlocutors in the Colombian peace process, which was to come in the years following the documentary. While there was hope that Pecados de mi padre could mark an interruption of the cycle of violence and revenge that has become associated with the recent history of Colombia, all indications are that reconciliation between the Galán, Lara, and Escobar families remains to be seen.

HBO's distribution of Pecados de mi padre is also indicative of-yet another-commodification of Pablo Escobar's legacy. In this respect, I find it very interesting to compare the two different beginnings the production company devised for, respectively, the television and cinematic release of the documentary. The latter begins with an idyllic scene of tranquility set in the midst of the Colombian jungle, where birds surrounded by bright colors appear to chirp the day away. As we follow the traveling camera, we notice laborers manufacturing coca paste, then carrying it out along the hillsides and into the city. As the focus moves from land to sky, we finally see a bird's eye view that shows a broken map of Colombia. This opening foreshadows the prevalence of drug consumption and its influence on the national imaginary. The spectator is thus immersed in an almost psychedelic experience (as if under the influence of drugs) produced by an animation technique that paints fluorescent colors over live-action images. At first sight, this opening would appear to anticipate a mood of harmony, but attention rapidly shifts to the harsh realities of drug trafficking. This shift, however, does not occur in the television opening for the Discovery en Español channel, which carried the broadcast of Pecados de mi padre in Latin America before the documentary became available on streaming platforms. In the Discovery version, right from the start the narrator identifies Pablo Escobar as a powerful villain, who dominated Colombian politics and daily life for the better part of the 1980s and early 1990s. The narrator's lapidary opening statement"Colombia, a violent nation where an assassination is followed by revenge, where a man stands out above all: Pablo Escobar"-leaves little room for idyllic images of life in Colombia, and replicates the portrayal of Escobar in Entourage's Medellin.

What we see here is that the kind of media packaging proposed by Discovery en Español (Latin America), HBO, and others that relish in Escobar's legacy is largely based on personalized narratives claiming to be historically grounded (and not simply pulp). Such narratives clearly operate according to the aforementioned South by North market dynamics that are reminiscent of colonial practices: Latin American sites such as Escobar's Medellín are now being expropriated for worldwide consumption and providing international audiences with appealing stories of survival, adventure, corruption, marginality, sex and violence, justice, and reconciliation. Similarly, it is clear that media producers like 
Discovery Channel or HBO, even when they try to move away from such dynamics, end up perpetuating the practice of trafficking in the personal for global consumption.

\section{Colombian Narco-Soap Operas: Cocaine and Crime for Global Consumption}

In a special issue of Revista de Estudios Hispánicos (2008), María Fernanda Lander lays out a narco-geography based on the map of Latin America as outlined by government agencies that fight against drug trafficking. The route proposed by Lander leads us to explore narcoviolence in the Mexican state of Sinaloa (Gabriela Polit Dueñas), Mexican and Colombian narcocorridos in the transnational context (Miguel Cabañas), and neo-realistic aesthetics in the sicaresca (Héctor Fernández L'Hoeste). Lander's approach aims at offering a response to the critical interest around the incursion of Latin American localities ravaged by crime and social chaos within the media conglomerates of cultural production. As Diana Palaversich points out in her study on the Mexican narco-novela, "there is no doubt that the emergence of the 'narco' genre is due, among other factors, to its proneness to marketing and to the ease with which this topic can be transformed into fiction" (104). This phenomenon also responds to what Arjun Appadurai has pointed out about geographies: in the global era they are no longer marked by a specific scale or space, but rather by disjunction, their different speeds, axes, and points of origin, that is, by a relational and contextual framework that he calls "a world of flows" (178) and that María Helena Rueda sees as "the result of a series of displacements" ("Escrituras" 391). Following such a contextual framework of transnationality, I propose to explore the narco-soap operas as a media genre that has global and local cultural ramifications.

In this regard, it is quite illuminating to draw parallels between the history of the drug trade in Colombia and the current channels of commodification of narco-stories since a similar pattern of production and consumption emerges. If localized enclaves in Colombia supplied the world with drugs beginning with marijuana from the Santa Marta region in the 1970s and cocaine from remote labs dispersed in Antioquia in the 1980s and 1990s, narco-stories have followed a similar supply chain, albeit licitly and with much less profit margins, from Medellín to the world. The rudimentary cocaine labs that blanketed the Antioquia region under Escobar were not really that far off from the artisanal production of cocaine by the Muiscas, Colombia's indigenous tribe linked to the legend of El Dorado. Drug lords like Escobar soon realized that the mass production of chemically processed coca paste in rudimentary local labs for worldwide consumption was possible at a low cost. In Escobar, we can see the figure of a magician-a "rainmaker," and an "omnipotent provider" in Herlinghaus's words-who was capable of creating a 
transnational business based primarily on the agricultural structures and manufacturing practices that have long been associated with Colombia's pre-colonial past (Narco-epics 99-102).

In this regard, the conversion from coca leaves to processed powdered cocaine was already part of the indigenous culture in Colombia, as the Muiscas use poporos (pipe-like containers) in which such conversion would take place "organically" by chewing coca leaves with small amounts of burning crushed seashells mixed with lime inside the poporo. The chemical reaction of this mixing of saliva, chewed coca leaves, burned shells, and lime coming from golden poporos can be seen as the precursor of the modern use of acetone to transform coca leaves into cocaine. For Michael Taussig, this "transgressive substance" combined two distinct objectives of the Western economy: gold (for capitalist accumulation) and saliva (as a worthless or unproductive substance), bringing together the accumulation of gold and "white gold" as two fetishized commodities in modern times: "Like gold, cocaine is imbued in violence and greed, glitter that reeks of transgression" (Taussig, My Cocaine Museum xi).

Violence, no doubt, has long been attached to the illicit drug trade and can easily be traced in the history of transnational commerce that began in the late 1800s when white gold became a national commodity in Peru. As Paul Gootenberg details in Andean Cocaine: The Making of a Global Drug, coca was soon thereafter launched on the international world market as a tonic in the manner of quinine, and unsuccessfully marketed as another potential colonial export (like tea, coffee, or cocoa) for consumption by North Americans and Europeans. ${ }^{21}$ The initial failure to establish a legal and profitable international trade for coca leaves in the nineteenth and early twentieth centuries was forgotten in the 1980s when Colombia became a powerhouse for the illicit processing of cocaine. But, prior to that, there was a marijuana boom, the so-called bonanza marimbera of the 1970s. As Lina Britto details in Marijuana Boom: The Rise and Fall of Colombia's First Drug Paradise, this bonanza still remains partly a forgotten history of Colombia's role in the international drug trade. The trade channels and routes for the illicit commerce of marijuana from the Santa Marta region were, without doubt, the preamble for what later became known as the Colombian cocaine boom of the 1980s and 1990s (under the leadership of Pablo Escobar and the Medellín Cartel): "the marijuana boom was also a critical component of hemispheric relations to the extent that it served as a training ground for the 'war on drugs' in South America" (Britto 2). Likewise, such a boom created opportunities for capital accumulation on the part of Colombians and established world markets with local and global dynamics of production, distribution, and consumption (9-12). There are also geopolitical and cultural reasons for Colombia's infamous recognition as the world's leader in cocaine production; for one, coca cultivation and consumption have long been a part of rural cultures; for another, the coup d'etat in Chile in 1973 and Fidel Castro's firm hold to power under the 
US blockade starting in the 1960s forced new smuggling routes for drugs (marijuana, cocaine) to make their way North from Latin America; and, for good measure, the US had a strong Colombian diaspora due to civil war conditions in Colombia during the 1940s-1950s period known as La Violencia.

Following these historical developments, a pattern of international commerce was established whereby Colombian legal exports (e.g., rubber, coffee, bananas) and illicit goods such as marijuana and cocaine-and to a lesser extent poppy, opium, and heroine (Thoumi 74-75)—were transported up North and sold for large profit. The same pattern also applies to cultural goods, narco-soap operas being the example at hand in the section. It accounts for the way in which Escobar continues to shape narco-culture decades after his death, which ultimately propelled mediadriven representation of excess consumption. Not in vain, as Hoyos cleverly reminds us, in the case of globalized narco-stories, it appears that "opium-or cocaine, rather-is the people's new religion" (127) or even new cultural addiction. Beginning in the early 2000s and following the cultural addiction to narco-stories, Colombia's media networks like RCN and Caracol saw the enormous potential in pairing narco-culture with the well-established genre of the Latin American telenovela (soap opera). In many senses, narco-stories and telenovelas go hand in hand as they often have stories from rags to riches that share melodramatic overtones, deception, betrayal, beauty, exuberance, and crime.

The prime example of this cultural phenomenon may very well be Gustavo Bolívar Moreno's bestseller novel Sin tetas no hay paraíso (2005) and the subsequent television series adaptation (2006). It captivated audiences with the melodramatic story about a young prostitute, Catalina, seeking to augment her breasts to please narco-traffickers' desires and, in return, secure better living conditions for herself (and her family). In both the novel and the television series, Catalina is called a "pre-paid" (prepago) girl who chooses prostitution as a way to escape the modest living conditions in her neighborhood in Pereira. In order to move up from one rich drug lord to a richer one, she has to undergo several breast surgeries: the larger the amount of silicone being added to her breasts, the more comfortable her living conditions become. But, as it turns out, breast augmentation has its limits and Catalina's body ultimately gives in and rejects the silicone implants, resulting in an urgent mastectomy that must be performed to save her life. As a consequence of being (again) flat chested, she no longer conforms to the beauty standards sought by narco-traffickers and quickly falls off grace and into her selfdestruction and death.

It is important to contextualize this ending to Catalina's story within the larger framework of beauty and violence in Colombia, which Michael Taussig addresses in his study of beautification surgeries gone awry. As he points out, it is surprising to hear about so many stories of bad Colombian cosmetic surgeries (or "cosmic surgeries" as he calls them) but even more 
surprising that many such stories seem to be "taking delight in the death or disfigurement of the patient" and its encompassing "eroticized excess" (Beauty $\mathrm{ix}-\mathrm{x})$. Catalina's dramatic story in Sin tetas no hay paraiso is a good example of how international audiences relish in such eroticized excess, in the mutilation of her breasts, and the ultimate consumption of her body. For Hermann Herlinghaus, such narco-stories promote in global audiences the enjoyment of a spectacular violence without guilt on the part of consumers and cultural producers (Violence 4-5). This is in line with what I have described about narco-stories that are anchored in dirty realism, marginality, and human suffering that are avidly consumed by global readers and television watchers.

Likewise, this intricate relationship between beauty and violence is what's being marketed in narco-soap operas such as El capo (2009), Las muñecas de la mafia (2009), El cartel de los sapos (2008), El patrón del mal (2012), and Los tres caines (2013). These productions highlight the fact that crime and passion have become key pieces of Colombian cultural production for local consumption and global export. Featuring handsome actors and beautiful actresses (papacitos and mamacitas), an unparalleled cult and addiction to silicone (and to cocaine), sumptuous interior decorations, artificiality and over-acting, sexist performances that often verge on camp, and catchy soundtracks, these narco-soap operas have captivated both local and global audiences. They have done so precisely because of their successful representation of the narco world and the exemplary display of wealth and excess consumption heralded by criminals. Crime is therefore re-positioned as a cultural commodity ready for consumption, a source of "cultural" entertainment that promotes the most spectacular components in the history of drug trafficking at the expense of any ethical evaluation. In other words, the goal seems to be to display the spectacle, to create media addiction to narco-aesthetics, and to avoid any ethical judgment on the characters' performances and on their multiple crimes.

Entertainment often trumps artistic craftsmanship in the case of these narco-soap operas. As Óscar Osorio points out, Bolívar Moreno's novel is "one of the worst written novels in Colombian literature" with "an ostensible aesthetic deficiency" (72). Aesthetic value or literary quality-indeed tricky terms to define-is not always commensurate with publishing success or even global market conditions. It could be said that Bolívar Moreno's "Tetas Factory" (222)-incidentally, the last words in the novel-illustrates the maquila dynamics in the global cultural market, the taste for corporal abjection, dirty exoticism, and the illusory proximity among global readers and marginal subjects. But Bolivar Moreno-author of more than 2,000 television scripts, as he declared in a 2010 interview for the newspaper El Tiempo (Velasco)takes pride in the fact that his works are not simply pulp; they document a new reality for the lower classes, as attested by his use of journalistic reporting. For instance, he would argue that in Sin tetas no hay 
paraíso he does offer historical information on the displacement of " 3 million Colombians since the 1980s" or the "murders of five presidential candidates" between 1986 and 1995 (Bolívar Moreno, Sin Tetas 45), but, clearly, without elaborating these statements or providing any more details. While Bolívar seeks to validate or give a certain cultural or historical weight to his melodramatic story of drug lords and prepagos amidst the new social reality imposed by the laws of drug trafficking, ultimately his works expose the predominance of levedad histórica (which he claims to deviate from).

Driven by the success of its television version, Sin tetas no hay paraiso served to promote narco-aesthetics through a wide distribution and marketing in various formats, which include a film version (2010) directed by Bolívar himself, many international adaptations of the original series in Europe and the US, and the sequel Sin senos si hay paraiso (2018). This latest installation of Bolívar's "tits factory" follows the steps of Catalina's half-sister (also named Catalina), who was born out of a quasi-incestuous relationship between Catalina's "original” boyfriend and her mother in the 2005 television series. Bolívar's Sin tetas became the most popular narco-drama on the international market, with versions in Spain (Telecinco), Russia, Mexico, and the US (Telemundo) that emulate the original Colombian show. And, within the global market's capitalist logic, it is not surprising that an English version was pitched to NBC, owner of the Spanish-language channel Telemundo, which already produced its own version under the prudish title Sin senos no hay paraiso (De la Fuente 20). This first version for the Hispanic market in the US had to "adapt" Catalina's "tits" to "breasts" for fear of offending more puritanical audiences in the North. It could also be expected that the English version (when made) will cut the most controversial scenes of the soap opera-for example, Catalina's gang rape and her subsequent abortion, the graphic images of her cosmetic surgery, or the display of obese drug lords in tight swimsuits. Whether they are called tits or breasts, Bolívar's success is largely based on the South by the North and the maquila scheme that favors the localized assemblage of products for worldwide export. With this model of global media dissemination, the diversification of Bolívar's "Tetas Factory" reinforces excess consumption as the driving force for these narco-soap operas. ${ }^{22}$ It is also important to note that streaming platforms such as Netflix offer access to these narco-soap operas in multiple languages and countries, contributing to the perpetuation of a violent vision of Latin America seen through the "unbearable lightness of history" (levedad histórica).

Other attempts (in my view, somewhat less successful) to provide historical weight to narco-dramas are the serials produced in the 2010s, El patrón del mal, Los tres caines, and Narcos. Documentary and real news footage are prevalent in these television series as they seek to provide a certain level of didacticism concerning the historical legacy of Pablo Escobar and Colombia's history of paramilitarism. ${ }^{23}$ But, despite 


\section{0}

Narco-Stories Globalized

these lofty efforts on the part of media giants like Netflix and Caracol, these narco-dramas undermine their supposed documentary value with melodramatic over-performances and an emphasis on the recreation of passions that are more closely related to the telenovela genre. This is the case of Los tres caines, a controversial take on paramilitarism and the drug trade through the heroic enthronement of Carlos Castaño, the founder of AUC (Autodefensas Unidas de Colombia). This serial's final scene (which is reached after a complex series of plot twists and turns driven by envy, hatred, and personal revenge) illustrates the highest point of melodrama, throwing into question historical validation. Specifically, I refer to the confession by Vicente Castaño-the so-called "teacher" or ideologist-strategist of the paramilitary group-to his mother and other family members of his direct responsibility for the death of his younger brother Carlos Castaño, the founder and military commander of the AUC. This final moment of empathy (and sorrow) toward the Castaño brothers as heroic figures whose actions are ethically justified to the detriment of the victims who suffered their atrocities does not correspond to the historical reality of Colombia's paramilitarism or to the way in which Carlos Castaño was killed. ${ }^{24}$ To appease the criticisms that this scene and the series create and to reactivate its pedagogical nature, the producers added a final scene, in which the actors see a short report on a screen about "the reality of paramilitarism" in Colombia and the ultimate fate of the Castaños and the AUC. Undoubtedly, this report sought not only to silence the criticisms of victims' associations but also to validate the purported historical weight of the series.

Narco-dramas, as Héctor Abad Faciolince reminds us in his essay "Estética y narcotráfico," successfully display "the sordid cult of vulgarity, thugs or their plastic women"-all within the narco-aesthetics that blends the ideology of US-style nouveau riche with its counterpart in the Colombian peasantry: "the connection between a galloping horse, an exotic mansion and a red convertible" materializes as "the secret dreams of our half-rich" and the mafia boss's "latent taste of the bourgeoisie" (513-517). But, as Martín-Barbero reminds us, melodrama is the main "identifier" for this genre, as social and emotional structures come together in an effort to blend "who we are" and "who we want to be" (216). That is, in part, the success of narco-soap opera's local and global appeal, as audiences engage in a transactional operation of acquiring (if only for the show's length) the nouveau riche's taste and "easy" access to inordinate amounts of capital. ${ }^{25}$

Similarly, Hugo Benavides places the Latin American narco-dramas (mainly in the case of Mexico) as instances where the reconfiguration of social identities, hegemony, and popular culture takes place: "narcodrama affects and is affected by the greater discourses of globalization present in the Americas today" (129), hence responding to the prevalence of anti-heroes, extreme poverty, and narco-violence which dominate the 
media discourse. For Benavides, it is also a very lucrative project-one of the most profitable on the continent, along with remittances-in which a translocal identity is established through a global hybrid phenomenon that is shared in the North and in the South (for example, the soap opera Betty la fea / Ugly Betty), following the trends imposed by the neoliberal economy.

It is clear, then, that there are more intrinsic reasons at play in the incorporation of local cultural products into the global market. Those reasons have to do with the original localities that define the success of such products. In the first place, the false proximity that Masiello considers typical of the levedad histórica in Latin American best-selling products must occur between local marginal subjects and global readers. Therefore, the location of the former requires a certain genuine value, that is, the presentation of those subjects must respond to a specific historicity recognizable to non-local audiences. In the second place, it would be necessary to explore genuinely local elements that are not entirely unrelated to globalization. In the case of Sin tetas no hay paraiso, the Latin American soap opera melodrama coalesces with the mafia and criminal aesthetics to explore the class relationship that shapes the Colombian social imaginary. Although it is exported as a cultural product in the global market, it still keeps in itself a "local wealth," a maquila production that generates revenues locally but whose main gains come from the worldwide market.

As Héctor Abad Faciolince concludes:

We suffer from a kind of fascination for evil; we worship the very dubious heroism of the murderers [...] in the past, there used to be a reverential fear for their violent acts; now it is worse: their words are read with relish.

(“Estética” 518)

Those words are now sold in paperback editions or on a large scale through DVDs and streaming platforms, and are part of mass media distribution in which Latin American authors are purveyors of a rich portfolio of dirty realism. Readers and television audiences alike are now, and more than ever, direct participants in the global consumption of marginal localities, insofar as those localities are marked by a false proximity and immediacy toward local subjects and by spectacular and criminal versions of Latin America, which tend to gravitate more and more often from the extreme of the magic toward that of the dirty. Narco-soap operas are nourished by the velocity that characterizes today's global cultural experience, an experience that, in the Colombian case, seems to be governed by multiple levels of addiction to an underworld dominated by cocaine, silicone, crime, and excess consumption, which ultimately catches the popular imagination of global viewers. 


\section{Notes}

1 The photographs of Escobar's dead body rapidly became available in print and visual media and are now just a click away on the internet. Heralded by the authorities as a moment of triumph and victory for Colombia, the killing per se did not stop drug-related violence and contributed to augment Pablo Escobar's legend as martyr and popular hero. See, for example, the photographic compilation offered by Bogotás daily El Tiempo:

www.eltiempo.com/colombia/medellin/pablo-escobar-gaviria-imagenesde-los-atentados-y-la-muerte-del-capo-de-medellin-298774.

2 Pobutsky's recent monograph on Escobar and narco-culture offers one of the most extensive archives of Escobar's representations worldwide, particularly in popular culture representation. The book establishes the "Escobar brand" as "cornucopia of stimulating tales" (Narcoculture 230) and tastes, which include (among others) tell-all memoirs written by women closely associated with Escobar and the drug trade, narco-soap operas, biopics, documentaries, best-selling fiction, T-shirts, street artists' portraits, images from bars and burger joints inspired by Escobar's legacy, and a photographic sampling of the ruins of Hacienda Nápoles, Escobar's ostentatious estate in Antioquia.

3 I am drawing here from Magnus Boström's essay "The Social Life of Mass and Excess Consumption," where he explains that "excess consumption is not synonymous with mass consumption but refers only to that share which exceeds sufficiency" (268). For her part, Andrea Fanta argues in Residuos de la violencia that drug trafficking promotes a culture of excess, whereby purchasing power is used to gain access to the "stagnant Colombian upper-class" $(\mathrm{xv})$ - something we see fictionalized in Restrepo's Delirio.

4 It is fair to say that the movie version of La virgen de los sicarios, directed by Barbet Schroeder in 2000, along with its subsequent success in both independent and mainstream circuits, was a key factor for the massive distribution of Vallejo's work beyond the Spanish-speaking markets, particularly in France and the US. Like the film Rosario Tijeras, Schroeder's movie evinces the mediatic ease with which these texts about sicarios are massively incorporated into a global market that is eager to receive them as valid samples of cultural difference in line with the maquila effect pointed out by Yúdice. See also Pobutsky, "Towards the Latin American Action Hero"; Fernández L'Hoeste, "From Rodrigo to Rosario."

5 Similarly, the characters of Laura Restrepo's Delirio provide the reader with both a narrative about delirium and a delirious narrative. The protagonist, Agustina, and her family represent a bourgeois class that-surreptitiously and omitting their support to the Escobar cartel-has entered, through their financial investments, into the network of money laundering associated with drug trafficking, which allows them to maintain their comfortable status in Bogotá's society. Agustina, in a sudden and inexplicable psychotic state, remains delirious for most of the novel. This is articulated through a multivocal narrative strategy in which the main characters' voices flow between the first and the third person, the interior monologue and the stream of consciousness. Such a composition attempts to establish a linear and logical narrative which is impossible in "the puzzle of his memory" (32), because "delirium lacks memory. [...] It twists around itself and can do without affect, but most of all it lacks memory" (85). 
6 Balderston also explores Vallejo's debt to Proust's work regarding a possible "identification between narrator and author" (160). In In Search of Lost Time Marcel is mentioned as the narrator's possible name. In La virgen, Alexis reveals Fernando's name just when he's threatened by the mortal bullet directed to the sicario: "Watch out, Fernando!" (78). Rosario Tijeras- "via Vallejo" rather than "via Proust"-repeats this identification process on the part of the narrator, at the moment that his name is finally revealed three pages from the end of the novel, when Rosario is ready to die: "Let's better sleep, Antonio—she told me" (164; see Jaramillo 430-432).

7 Likewise, in Rosario Tijeras the story is being narrated while the protagonist hovers between life and death in the operating room. Rosario's story is interspersed with the present time in the hospital where she agonizes. The narrator is repeatedly conscious of the impossibility of reconstructing the order of the events, or even of making any logical sense of what the main character has gone through in order to do justice to her memory and, therefore, to the story of this popular heroine: "I've had to struggle with my memory to remember when and where we'd seen each other for the first time"-Antonio comments at the beginning of the novel (23). This is again reiterated toward the end, when approaching the fatidic outcome for the main character's state: "The moments that followed were so confused and so strange that it's still hard for me to put them together. I don't remember exactly the order in which they occurred [...]" (157).

8 Similarly, in La virgen de los sicarios, the writer who returns to Alexis and Wílmar's Medellín is, as Javier Murillo puts it, "an eternal exiled from his own world, [who] wanders alone in an alien world along with his intercessor"; this narrator who "wanders dumbly" represents the "dissolution of the world and of language," as well as "the dissolution of the I" ("La voz" 244-248). For an in-depth analysis of ghosts in Colombian cultural production, see Martínez's Haunting.

9 Vásquez is, no doubt, one of the most successful Colombian writers in the global literary market. His novels-Los informantes (2004), Historia secreta de Costaguana (2007; winner of the Qwerty Prize), El ruido de las cosas al caer (2011; winner of the Alfaguara Award), and Las reputaciones (2013) have been translated into several languages and circulate widely. His trajectory is that of a global writer who has lived extensively in Europe (Paris, Barcelona) from where he writes about forgotten episodes of Colombian history (e.g., Nazism in Colombia, Panama's secession from Colombia, the first "narco-pilot" of the Escobar era, the life of Colombian political cartoonist Javier Mallarino) to reconstruct its historical memory from the national periphery.

10 Pobutsky opens her book on narco-culture with a brief summation of the hippopotamus's killing. She mentions the reaction in the Colombian press and general discontent on the part of pro-animal rights groups (1-2). O'Bryen's essay includes photographs of the slain hippo and the killing of Escobar (“Affect" 243).

11 Similarly, the final section of Laura Restrepo's Delirio emulates the famous ending of Cien años de soledad:

se hubiera sumergido esa misma noche en la lectura de los diarios y las cartas para empezar cuanto antes a descifrar quiénes habían sido 
en realidad el alemán Portulinus y su esposa Blanca. A veces tiene que esperar siglos a que ocurra alguna cosa y de golpe ocurren todas a la vez.

he would have immersed himself that same night in the reading of the diaries and letters to begin to decipher as soon as possible who had really been the German Portulinus and his wife Blanca. Sometimes one has to wait for ages until something happens and then suddenly everything happens at the same time.

(331; my emphasis)

For Polit Dueñas,

Restrepo wants to build the archive of her narrative appealing both to the Colombian literary tradition and to the existence of a mythical original sin [...] The story of Nicolás Portulinus and her wife Blanca consists of a series of scenes that resonate with the stories of Melquíades in Cien años de soledad.

(“Sicarios” 139)

Unlike García Márquez, Restrepo refuses a mythical ending to her novel, not suited, perhaps, to the readers of dirty realism in the new global literary market. In Delirio, the repetitions of the family saga are neither the spur to the apocalyptic destiny, nor established in an interconnected way as the cause of the malaise of family and nation.

12 Rita de Maeseneer and Jasper Vervaeke argue that in Vásquez's novel sonic expressions are closely linked to recovering a painful past. By examining the role played by visual and auditory memory in the act of remembering, they point out the limitations of written language to enact painful memories of the past as suggested by the novel's emphasis on aurality-sounds, noises- “to activate the processes of recalling the past or to create echoes between past and present" (406).

13 Nam Le received several awards and scholarships (as we learn from the biography on his website), and was also one of the participants in Iowa's renowned writers' workshop. The Boat was originally published in English by Knopf in the US and Canada in May 2008; it was then released in Australia, and from there it was published in Germany, Italy, the Netherlands, France, Israel, Croatia, Finland, and Vietnam. In 2010, the book was published in Spanish by Random House, a publishing house integrated into the Bertelsmann conglomerate. See http://namleonline.com.

14 Donald G. Goellnicht sees the inclusion of Nam Le himself in The Boat as a "meditation on ethnic writing" and "a meta-critique of the cultural policy of American ethnic writing" (199-200). Nam (the character) offers the following reflection in this regard: "I had two and a half days left. I would write the ethnic history of my Vietnamese father. It was a good story ... At the top of the page I typed 'ETHNIC HISTORY' in capital letters" (Le 28). Such opportunism is not so easily justifiable in the story "The Boat," since it demonstrates "the tremendous difficulty and real physical cost that ethnic writing entails" (Goellnicht 220). It should be noted, regarding the representation of ethnicity, that the audiobook version of "Cartagena" is narrated by an actor of Hispanic origin, Jesús Martínez. Also, the narrator in the audiobook for "Love and Honor" is James Yaegashi, of Asian origin. 
15 Marco Palacios's Violencia pública en Colombia, 1958-2010 presents a broad historical overview that offers a good context to understand the negotiation process between Pastrana and the guerrillas, as well as its ramifications in the Plan Colombia. For a more detailed analysis, see the sections "Pastrana: los límites de las políticas de la paz" (158-165) and "El Plan Colombia, la seguridad de los Estados Unidos y la política colombiana” (165-167). Palacios's book also contains an extensive bibliography on the peace processes in Colombia (197-218). In this regard, Vellinga sees the so-called "war on drugs" as something that "no government can win or lose" (17), since it is hard to break the illicit drug trade's chain of production and marketing under the existing economic conditions for localities that cultivate coca.

16 The English version uses Spanish words like gallada [gang] (33), basuco [low-grade cocaine] (30), or sacol [an industrial glue inhaled by street kids in Medellín] (32). The Spanish translation of "Cartagena" keeps these words from the English text in italics with a footnote (Le, El barco 43). Also, the Spanish translation of "Cartagena" makes an important idiomatic error: the sicarios use the expression "tío" (Le, El barco 43) as a translation of the word "man" in English. It would have been more appropriate to use Colombianisms such as "parcero," "parce," “man," or "manes" to avoid using the idiomatic register of peninsular Spanish to reproduce the colloquial slang of Colombian youth. Although this detail does not nullify the validity of the translation by Ignacio Gómez Calvo and Marc Viaplana, it is important to highlight it, since with the use of the word "tío" the text establishes a more direct rapport with a European audience.

17 Gustavo Forero offers an apt analysis on Colombian crime literature by incorporating the concept of "anomie"-i.e., "state of anarchy," "state of deregulation," or "state of misgovernment"-in the discussion around texts such as La virgen de los sicarios (Forero 34-35). Such "de-regulation" operates both at the level of narrative and of plot construction in the works of Vallejo and Franco. See also Herrero-Olaizola's "El mercado del crimen."

18 See www.youtube.com/watch?v=wSpHeWRYYVE\&ab_channel=Deathto Utopia.

19 Another example of major television network utilizing Pablo Escobar for mass consumption is the ESPN documentary The Two Escobars, which explores the connections between Pablo Escobar and the Colombian national soccer team that underperformed in the 1990 World Cup, in part due to the infamous own goal in a game against the US by defender Andrés Escobar, who was ultimately killed upon his return to Colombia.

20 In an opinion article, Mario Vargas Llosa points out that this is not "a specific documentary on drug trafficking" but rather on the "survival or collapse of the democratic regimes of Latin America" (El País, May 30, 2010). For more on narco-politics in Colombia, see Betancourt's Until Death Do Us Part.

21 See also Roberto Saviano's Cero Cero Cero: cómo la cocaína gobierna el mundo for a journalistic exposé of the interconnections between drug money and the global economy, and their effects on society.

22 A cogent example of a transnational narco-soap opera is La reina del sur (2011), which is based on the 2002 bestseller novel by the Spanish writer Arturo Pérez Reverte. Filmed in Colombia, Mexico and Melilla (an enclave for the international drug trade), it details the journey of Teresa Mendoza, the 
girlfriend of a slain drug lord from Sinaloa, whose murder pushes the heroine to escape Mexico to Europe and, ultimately, to become a narco baroness. This narco-soap opera has been distributed in over 100 countries and dubbed in 15 different languages. There are, at least, 22 adaptations of the television serial and 24 translations of the novel into different languages. See www. perezreverte.com/libro/41/la-reina-del-sur/.

23 The figure of Pablo Escobar keeps captivating the popular media market, as evidenced by the 2012 Caracol television series El patrón del mal (2012), which has conquered the US television market with its rebroadcast on the Telemundo network. This series is based on the text by Alonso J. Salazar, which was originally published under the title La parábola de Pablo (2001) and was published as "the book that inspired the soap opera" (according to the cover) under the title Pablo Escobar, el patrón del mal (see, Herlinghaus, Narco-epics 93-125). Escobar is also featured in Los tres caines (2013) as a friend and foe of the AUC in the drug trade. This serial enraged victims of paramilitary warfare in Colombia, since the TV series "humanized" the Castaño family and justified many of their criminal actions as "attempts" at saving the nation from the FARC guerrillas and from kingpins like Pablo Escobar. The serial's script was written by Gustavo Bolívar, who argued that it was based on interviews and testimonies collected under the Justice and Peace initiative (2006) to help the demilitarization process of illegal armed groups such as Castaño's paramilitary group.

See https:/elpais.com/internacional/2013/03/29/actualidad/1364521266_ 909995.html; also Andrés López's El cartel de los sapos (2008), which offers the "secret history" of the Norte del Valle cartel on which the TV series was based.

24 It is believed that Vicente Castaño did not actually kill his brother Carlos and that the execution plan was actually carried out by Vicente's security chief, alias "Mono Leche," with the understanding that Vicente was in the loop about the action against his brother. See "Confirmado: Carlos Castaño está muerto" (2006); see www.semana.com/on-line/articulo/confirmadocarlos-castano-esta-muerto/80598-3/\#: :text=La \%20muerte \%20de \%20 Casta $\%$ C3\%B1o\%2C\%20asesinado,Carlos \%20para \%20que\%201o\%20 traicionara.

25 Furthermore, Martín-Barbero adds that Colombian telenovelas decentralize the peripheral regions of the country (such as Risaralda in Sin tetas or Urabá in Los tres caines) that otherwise would not be visible to the nation at large (or to global viewers), but, in so doing, also expose the state's regulatory centralization. See also Herrero-Olaizola's "Crimen sin castigo: narco dramas para el mercado global." 


\section{The Ingrid Betancourt Story Memory in the Times of Mass Media}

The kidnapping of former Colombian Senator and presidential candidate Ingrid Betancourt has been one of the most captivating sagas in recent television and global media history. Taken by the FARC (Fuerzas Armadas Revolucionarias de Colombia) on February 23, 2002 and released six years later on July 2, 2008, Betancourt's journey from Bogotá to her adoptive France (where she spent her formative school years) and back to Colombian politics and the jungle has made an extraordinary tale about Colombia as a "hostage nation" (Bruce). And, more importantly, it has significantly contributed to perpetuate the country's global image as a violent, dangerous, and unsafe nation that is bound to produce stories of human despair, survival, and personal struggle for the world to embrace. As we know, since the mass media enjoys playing up dangerous and "up to the limit" human conditions to grab and retain their audiences, the Betancourt story provided for them one hell of a personal survival story. It was peppered with danger, mystery of the unknown in remote areas in the Amazon jungle, civil war conflict (carried out by guerrillas, paramilitaries, and the army) as well as personal conflict and deceit between Betancourt and her fellow prisoners. The international interest in the Betancourt story was sustained by news media reports on the inhumane conditions endured by FARC hostages in the jungle, Betancourt's several escape attempts, and the failed negotiations for her release. As her health deteriorated in captivity and, apparently, time was running out on her, international cries for her liberation continued to play well in the news. In turn, these developments made Betancourt a star in her own right and, arguably, the most talked-about victim of kidnapping worldwide over a six-year span.

But the Betancourt story evolved quite rapidly in the months after her liberation. Some of the "juicier" details of her life during her captivitysuch as alleged (and real) sexual relationships between captives and captors, the major falling-out between Betancourt and her political partner and vice-presidential candidate Clara Rojas (who became pregnant in captivity and gave birth in the jungle)—began to transpire in the news media as important milestones in Betancourt's personal struggle. It then continued with additional material to keep the story alive with

DOI: $10.4324 / 9781003195702-3$ 
captivating events for media consumption such as her divorce and her lawsuit against the Colombian government for failing to provide her with the necessary security protection during her last campaign stop in 2008 when she was taken hostage. The lawsuit (another interesting turn in the Betancourt story) was dropped within days of having been filed as a response to the public outcry and expressed outrage from the political class in Colombia. This same class had been most instrumental in her liberation, and, understandably, Betancourt was forced to publicly apologize for what many saw as her lack of gratitude.

As we know, what happens in the jungle stays in the jungle. So it is very likely that we will never know what really happened during Betancourt's captivity. It is precisely because of this uncertainty (some facts about her kidnapping and release don't quite add up) that the Betancourt story has continued to attract international interest precisely because the suggestion is that there is more to know, more to be found out. For starters, the conditions that led to her captivity are yet to be fully clarified: why was she denied protection from the Colombian security forces when she ventured into FARC territory near San Vicente del Caguán? What drove her incursion into the guerrilla zone despite the official warnings she apparently received? Why did a visit to San Vicente del Caguán seem so necessary for her presidential aspirations when she was barely polling at $7 \%$ at the time of her capture and had almost no chance of winning the presidency? More questions also surrounded her release, which did not lack controversy and conflicting reports.

The official version is that her liberation along with 14 other kidnapped victims was made possible thanks to an almost unbelievable military operation in which Colombian army operatives duped the FARC by disguising themselves as members of a humanitarian crew helping to regroup Betancourt and her fellow prisoners. The media coverage of her liberation from the moment the helicopter landed in a safe militarized area near San José del Guaviare was soon questioned by a Swiss radio news report claiming that a ransom of 20 million dollars was actually paid for Betancourt's liberation and possibly negotiated by the French and US governments through behind the scenes dealings with one of Betancourt's captors. While this side of the story has been vehemently denied by the Colombian government (and by Betancourt herself), the news media still picked it up and, in so doing, continued to provide international audiences with yet one more chapter in the unfinished (and apparently always evolving) Betancourt story. ${ }^{1}$

Undoubtedly, the plight of Betancourt's release was propelled by diplomatic and grassroots efforts in France, where Betancourt became nothing short of a cause célèbre and the embodiment of international solidarity with women deprived of their freedom. The fact that she had married the French diplomat Fabrice Delloye in the 1980s and together reared their two children made it important enough for the French public at large (and their elected representatives) to care about her captivity in the 
Amazon jungle. Another important fact in her success as a public figure in France was her close ties to the French political elite, having studied at the prestigious Science-Po in Paris, a school known as a breeding ground for the French political class. It is then no surprise that soon after her liberation, Betancourt stood at the Paris city hall before a huge banner of her image that declared her libre ("free") the same day the title of Honorary Citizen of Paris was bestowed upon her. It would seem that the story had come full circle with Betancourt back again rubbing shoulders with the French political elite and being brandished about as a symbol of freedom for all to embrace.

But this was just the beginning of the Betancourt story for the culture industry. The news media attention that preceded her capture and liberation was soon materialized in book and movie deals, which rehash well-known (or, at least, the most reported) episodes of her life in the jungle. Furthermore, the event prompted the release of new editions of her already published political memoir Until Death Do Us Part: My Struggle to Regain Colombia (2002) and the publication of Cartas a mamá (2008), which contains some of her personal letters while in the jungle. ${ }^{2}$ All these reconstructions of her captivity cash in on the memory boom that dominates global cultural production and, of course, on the interest of international audiences to consume memoirs of struggle and survival. This global interest in memory has produced a significant increase in the number of published works in Colombia that are devoted to the reconstruction of historic violence and the displacement of victims. This interest in global media events that are continually revisited through a wide variety of cultural products is, in my view, a direct consequence of the 24-hour news cycle that most of us (willingly or not) experience as part of our daily lives.

Thus, in this chapter I examine the Betancourt story in terms of its cultural production and global mass media dissemination, that is, I seek to explore Betancourt's captivity and release within the portfolio of diverse cultural products that emerged as a result of her kidnapping, and I analyze these cultural products in light of the recent upsurge in memory studies in Colombia. In particular, I engage with the term "media memory"- "the systematic exploration of collective pasts that are narrated by the media" (Neiger 1) -in relation to our understanding of collective memory within the specificity of Latin America and its tradition of testimonio. ${ }^{3} \mathrm{My}$ interest is to establish a linkage between this tradition-which peaked in the 1980s with accounts such as Me llamo Rigoberta Menchú - and globalized (media-driven) memoirs such as Betancourt's captivity narrative. Furthermore, I situate the Betancourt story as a global cultural product for mass consumption that fits perfectly well within the parameters of the Colombian condition, by virtue of which cultural production emerging from Colombia is assumed (and, moreover, expected) to be about violence, survival, struggle, and human despair. And because of this, cultural producers and distributors are 
bound to reproduce such conditions for the market in order to provide international cultural consumers with their expected dose of Colombian suffering. As we now access the past primarily through media outlets (television, internet, digital sources, and archives), our understanding of history (and collective memory, broadly speaking) is often channeled through the cultural market operations that bring us an account based on significant historical facts such as Betancourt's capture and release.

To understand how the cultural market forces have used (and abused) the Betancourt story, I discuss in-depth four sample cases that demonstrate the appropriation of her struggle for global cultural consumption: the French comic book Ingrid de la jungle (2010); Betancourt's captivity memoir-simultaneously released in French, Spanish, and English as Même le silence a une fine, No hay silencio que no termine, and Even Silence Has an End (2010), respectively; the television series about her rescue Operación Jaque (2010); and the film Operación E (2012) about Rojas's child born in the jungle. All these complementary accounts of the Betancourt story illustrate the market conditions that have led to an appropriation of the memoir (and memory) boom that has dominated the cultural output in recent years-one that international audiences avidly consume, notably in the case of Colombia. It is also important to mention that the release of the comic book, the captivity memoir, and the television series in 2010 "conveniently" coincided with Betancourt's failed lawsuit against the Colombian government for $\$ 6.5$ million. This apparent faux pas in fact revived the news media coverage of the Betancourt story and confirmed once more that there is no such thing as bad publicity, particularly when it is an ever-evolving story like Betancourt's and when it coincides with the launching of an important captivity memoir like No hay silencio.

Despite the fact that she may now be persona non-grata in certain circles in her country of birth, Betancourt remains an important figure in the recent history of Colombia. True, the media and the cultural market enthroned her as a "star hostage" but contributions to political and social causes are worth remembering-e.g., her exposé of "narco-politics" in Until Death Do Us Part, her presidential candidacy as an independent female candidate for the Partido Verde Oxigeno [Oxygen Green Party] which she founded in 1998, and the international visibility she has given (whether intentionally or not) to FARC hostages and their families. Furthermore, the Betancourt story put Colombia back on the map and, consequently, drew attention to the need for greater international involvement in putting an end to guerrilla and narcotics warfare. In this connection, it is important not to disregard the power of the culture industry to situate "worthy causes" in the forefront of public opinion even if such causes bring economic returns for cultural producers and, in the case of Betancourt, for hostages who write best-selling captivity memoirs like No hay silencio que no termine. 


\section{The Comic Story: Ingrid of the Jungle}

On September 15, 2010, only a week before Betancourt's captivity memoir was released, Ingrid de la jungle - the cartoon version of her survival story-appeared in France. It went almost unnoticed and had limited circulation, as it competed with the international launching of Betancourt's "real" survival story, published in French under the title Même le silence a une fin. The comic Ingrid de la jungle only began to circulate (albeit limitedly) beyond France through websites like Amazon Canada once the Betancourt story was back in the spotlight in September of $2010 .{ }^{4}$ Following the Franco-Belgian tradition of bande dessinée in the likes of Tintin or Astérix, Ingrid de la jungle offers a parodic version of the better-known details of the Betancourt story: her capture in 2002, her many failed attempts to escape, her connections with France's political elite, the political timeliness of her liberation by the governments of Colombia and France, and the news media fanfare that ensued from her release in 2008. Through 22 scenes that go back and forth between the jungle, Paris, and Bogotá over a six-year span, the comic's creatorsSerge Scotto, Eric Stoffel, and Richard Di Martino-parody the television media overexposure to the Betancourt story. While Ingrid de la jungle certainly feeds from and exploits that same media exposure it seeks to parody (and criticize), it nonetheless proposes a new take on these familiar captivity episodes in light of the behind-the-scenes maneuvering that allegedly went on during Betancourt's captivity and release.

To set the intended parodic tone in motion, the comic renames all the main actors in the Betancourt story by creating a parallel yet familiar universe for its readers, one that they can identify as real and laugh at it. Thus, the infamous Colombian guerrilla is the FARCE (for the French acronym "Force Armée Révolutionnaire Du Colombin Equatorial" [Revolutionary Armed Forces of Equatorial Columbine] and also the word "farce"); the protagonist is Ingrid Pétancourt (which could be loosely translated as "Ingrid Fartface"); the Colombian president is Urible (a blending of Uribe and Horrible); the French prime minister is Dominique De Grillepin (who is still in love with Ingrid back from her college years together); and the President of France (Nicholas Sarkozy) is the diminutive (in name and in size) Sarko. These characters are pretty much fixed in their roles throughout the entire storyline in predictable and consistent ways and in conformity with what has become our news media knowledge of the various actors involved in the Betancourt storyknowledge which, as I will detail in the next section, also parallels that emerging from Betancourt's captivity memoir. For the comic lead creator, Serge Scotto, these and other episodes in Ingrid de la jungle provide us with a different mode of access to the "real" story behind her captivity and release. He argues, for instance, that the comic book should not be taken lightly since it relies by and large on credible journalistic accounts and documentation. ${ }^{5}$ 


\section{2}

While some of the situations described in Ingrid de la jungle may seem unrealistic and contrary to what we know from the Betancourt memoir, the comic does contribute in the end to a reflection on the Betancourt story for global consumption. For example, the comic begins without preamble, in media res, right in the middle of the jungle-just as in No hay silencio que no termine-coinciding precisely with one of Ingrid's attempts to escape from the guerrilla camp. Similarly, No hay silencio and Ingrid de la jungle construct their narrative lines according to a temporal dislocation in which the protagonists move back and forth between their time of freedom and their time in the jungle. In this sense, both texts use the memory of the past as a point of reference for the time of the present from which their narratives originate.

In the comic book, Ingrid's memory of her kidnapping is triggered during one of her attempted escapes as she is trying to survive the harsh conditions of the desert (something fairly absurd if we take into account the Amazon landscape in which she was detained). As in No hay silencio (where Betancourt reconstructs her captivity memories through the benchmarks of her attempted escapes), the comic replicates the reflective process for the construction of memory that Ingrid herself deploys: "Au fond, cette histoire se termine aussi mal qu'elle avait commencé ..." [In the end, this story ends as badly as it started ...] (Scotto 20). But this reflective tone is not the norm in Ingrid de la jungle, as the comic book often uses absurdity (e.g., locating a desert in the middle of the hostage's escape route in the Amazon) as well as vulgarity to mock Ingrid and the other actors of the Betancourt story. The opening vignettes, for instance, show Ingrid in what appears to be an act of cunnilingus with a goat named Marcelo. As the image zooms in, however, we realize that there is no actual interspecies sexual encounter and that Marcelo is, in fact, biting off Ingrid's bonds so that, much to her satisfaction, she is set (temporarily) free.

In this manner, through verbal puns, sexual innuendo, and absurd situations, the comic seeks to offer a different spin on the Betancourt story as reported by the news media and the hostage's memoir: for instance, Ingrid herself and the FARCE stage her capture as part of a ploy to give her presidential bid more visibility and the guerrilla a chance to have a future president on their side (Scotto 21-22); the famous video of Ingrid sitting alone in captivity-the so-called prueba de supervivencia (proof of life) - is choreographed to show her in apparent declining health and poor mental condition (Scotto 31); ${ }^{6}$ in Ingrid's third escape attempt she manages to be picked up by the Colombian army but is immediately returned to the jungle on orders given by President Urible, who is afraid of losing his reelection to a possible Ingrid Pétancourt presidential bid (Scotto 26); and President Sarko, while benefiting from Ingrid's liberation and gaining support in the polls, feels overshadowed and displaced in the media by Ingrid's triumphant return to France and resents the former hostage for it (Scotto 45). The comic closes with a series of conversations 
leading to a television contract for Ingrid to participate in a survival reality show called "Premiere Compagnie" [First Company] (Scotto 45). As a result of her participation in the show, Ingrid will end up again in the jungle, in FARCE territory, and caught again in the news media frenzy that will make possible not only the continuation of the Ingrid story but also the prospect of another comic sequel, which is announced on the final page of Ingrid de la jungle along with the following questions:

Ingrid deviendra-t-elle une star de la TéléRéalité? Le Président Sarko remontera-t-il dans les sondages? Vous le saurez en lisant le tome 2 (...) des aventures d'Ingrid de la Jungle: Le retour d'Ingrid de la jungle.

Will Ingrid become a TV reality-show star? Will President Sarko come back in the polls? ... You will find out by reading the second volume of the adventures of Ingrid in The Return of Ingrid of the Jungle.

(Scotto 46)

As suggested in the final pages of the comic, the Betancourt story appears always as ready for further appropriation by the culture industry and for another chapter in the story-one that would inevitably lead to even more Betancourt memories for the world to consume. ${ }^{7}$

Interestingly, one most unexpected twist in the chain of cultural production is the actual involvement of the FARC in the Spanish translation of Ingrid de la jungle. For, somehow, the French comic reached the hands of the FARC guerrilla, and on February 9, 2011, one of its blocs-the FARC-EP "Bloque Martín Caballero" which operated in the Caribbean region-uploaded on their website (resistencia-colombia.org) an "unauthorized" translation titled Ingrid de la selva. The digital Spanish version-no longer available online at the FARC's website-is a complete page-by-page scanned document of the original French comic book in which the original balloons have been (sometimes more noticeable than others) whited out and replaced by Spanish translations (Figure 2.1). ${ }^{8}$

As can be seen in the comic book covers above, the Spanish version (Figure 2.2) is, in effect, a copy of the French original that has been altered to make it accessible to Spanish speakers, while respecting all the vignettes, the content, formatting, and lettering of the original (and the French flag colors in the corners). Furthermore, the Spanish book cover would indicate that this would be the published translation of the French original that one might be able to purchase, while it is, in fact, a translation and bootleg edition put together by the FARC. Interestingly, credit for the translation is not given to any individual but rather to the entire guerrilla group, who-one assumes-see themselves as the rightful owners of Ingrid de la selva and possibly of the Betancourt story altogether. It is unclear how the French comic reached the FARC, but the 


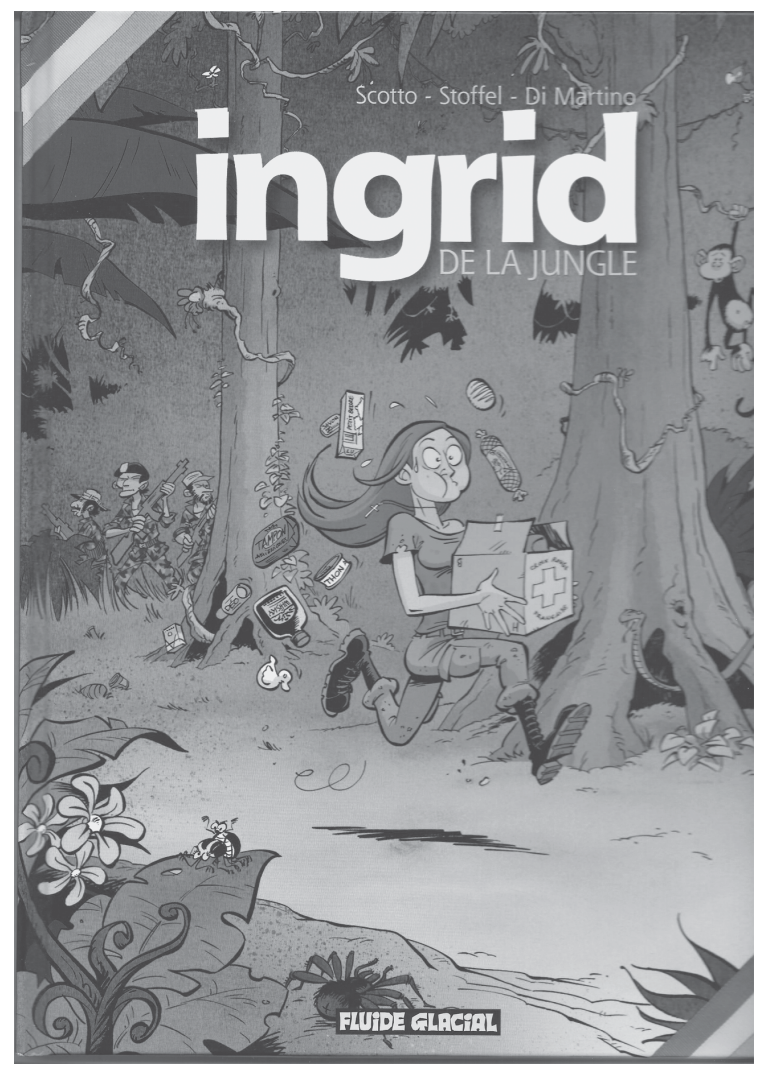

Figure 2.1 Ingrid de la jungle, book cover (original). Editions Fluide Glacial.

bootleg Ingrid de la selva appears to have the implicit approval of its lead creator Serge Scotto since his Facebook page offered a link to the FARC website where the Spanish version was posted on resistenciacolombia.org. There is no significant alteration in the plot or storyline of Ingrid de la selva, and, aside from a few side references for comic effecte.g., Lady Gaga replaces a reference to French resistance leader Guy Môquet (33) - , the FARC version matches the French original (color, design, lettering) without any editorial intervention on the part of the guerrilla. This, of course, suggests a number of questions: how did the FARC know about the French comic? Why did they choose to translate and upload Ingrid de la selva? Was there any involvement on the part of the comic book's creators?

Oddly enough, the FARC's translation and digital publication of Ingrid de la selva make the guerrilla one more cultural producer of the Betancourt story. By providing a free-access digital version of the comic book in Spanish, the FARC—in effect-sabotaged any potential efforts by 


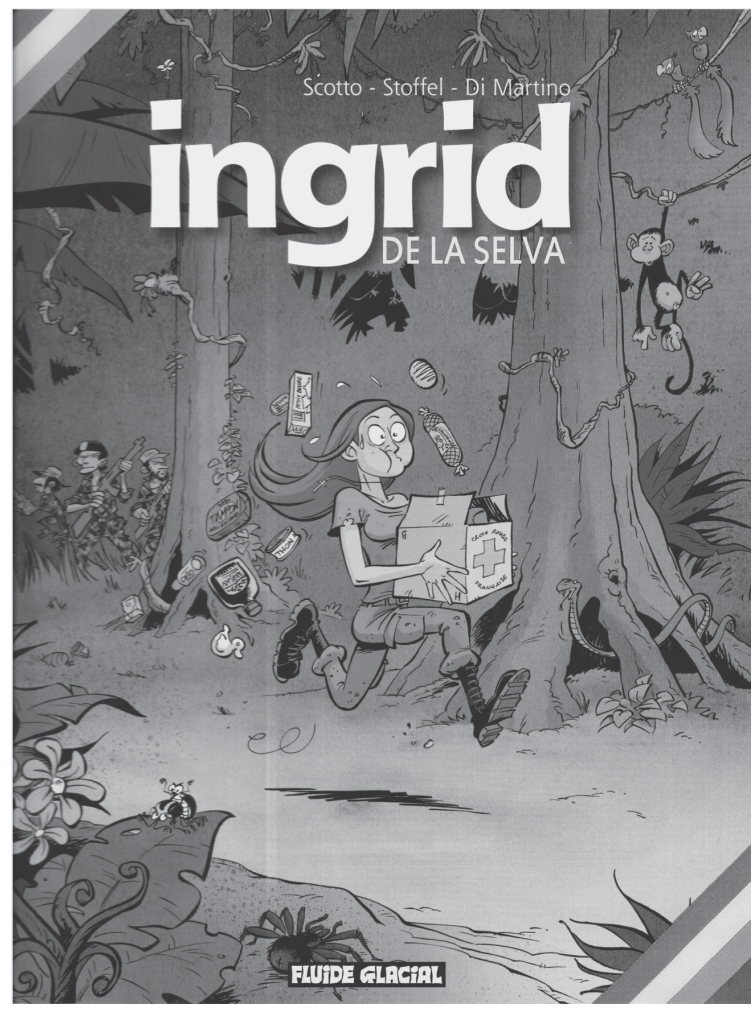

Figure 2.2 Ingrid de la selva, book cover (FARC).

commercial publishers to venture into publishing a bona-fide authorized Spanish translation of Ingrid de la jungle. By doing so, they "re-captured" the comic storyline resulting from their most prized hostage's survival story, and reacquired a sense of ownership of the Betancourt story. Arguably, the free digital access to the Spanish translation/adaptation resonates well with the guerrilla's anti-capitalist tenets, as it blocks further commercialization of the comic book, and, by extension, of the Betancourt story. This sense of ownership of Ingrid de la selva is apparent in the way they credited the translation on their website: "Escrito por una traducción de FARC-EP" [written by FARC-EP's translation]. Literally, Ingrid de la selva is written by the FARC through a translation as opposed to having been written by somebody else and then simply translated by the FARC. In this way, the guerrilla (as it were) regained control of "Ingrid" for the Spanish-speaking market and accepted the selfdeprecating humor in its pages, just as they embraced the portrayal of Ingrid as a "media star" and "princess of the political elite," which was already present in the French original. 
Furthermore, by embracing the parodic version of Ingrid's release in Ingrid de la selva as their own (co-)creation, the FARC may have found a way to save face concerning their alleged negligence in the liberation and rescue operation. As discussed earlier, the comic book proposes that, before reaching guerrilla territory, Ingrid had entered into an agreement with the FARCE for her to be held in captivity only briefly, as a way of favoring her presidential aspirations. Likewise, the comic book gives no credit for liberation to either the Colombian army, the president, or any special army forces. It simply points out that the rescue was an untimely error due to the camp leader's "temporary absence" in the bathroom (Scotto 35). The FARCE commander, thus, is not to blame for the naive stupidity of his lieutenants who get duped in his absence by French government operatives disguised as "Ché-loving" guerrilla fighters. ${ }^{9}$

These (bad) jokes aside, both Ingrid de la jungle and Ingrid de la selva refashion Betancourt, above all, as a pawn in the chess game of French politics, even as they ridicule the French political elite who used Ingrid's abduction and release to benefit their own political careers. In this sense, Ingrid de la jungle zeroes in on the feuds of French politics (Villepin/ Grillepin vs. Chirac/Chirabric vs. Sarkozy/Sarko) rather than on guerrilla warfare in the Colombian political context. It is precisely the comic's depth (or lack thereof) on Colombian matters that makes it an acceptable cultural product that does not quite threaten the Colombian status quo or the FARC's image. Rather, Ingrid de la jungle is, in this sense, a truly Franco-centric book in which Colombian authorities barely appear in more than a handful of vignettes, and the entire storyline is dominated by events occurring in the jungle but constantly being referenced back to France. Thus, it is a book intended mostly and mainly for French readers who are familiar with Betancourt but want to read the comic version of her story. The comic book therefore appropriates a Colombian story of survival and struggle to extend its reach well beyond its original national borders and markets it for a niche audience seeking to laugh about Betancourt's connections with the French political elite.

More importantly, Ingrid de la jungle anticipates-a week before the publication of Betancourt's No hay silencio-some of the global trends of cultural production and distribution that have ruled the Betancourt story. $\mathrm{My}$ interest in reading the comic version of the Betancourt story vis-à-vis her memoir (and in light of the historical memory boom in Colombia and the Latin American tradition of testimonio) has to do with the cultural diversification that this genre provides as an alternative version of the story. For Andreas Huyssen, "the memory boom [...] is a potentially healthy sign of contestation of the informational hyperspace and an expression of the basic human need to live in extended structures of temporality, however they may be organized" (Twilight Memories 10). Within this memory boom context, I take the appropriation of Ingrid by the creators of the comic book as a clear example of a mass culture product emerging from Colombia but being marketed from the outside 
for global consumption. ${ }^{10}$ While there is an unauthorized translation in Spanish (no longer posted on a FARC site but available for download on internet sites), still very few Colombians know of its existence (or really care about it). This goes to show how mainstream channels of distribution for the Betancourt story have rarely incorporated non-official versions of the story such as this comic version and its appropriation by the FARC. Ingrid de la jungle and Ingrid de la selva, a contrario, illustrate the commodification process that enthroned Ingrid Betancourt as an international star hostage and living example of the most chaotic and guerrilla-infested view of Colombia. Such a view was propelled by other media outputs (television, radio, internet) that, in effect, recognized the Betancourt story as ideally suited for the media. ${ }^{11}$

\section{No hay silencio que no termine and the Memory Boom}

Ingrid Betancourt's No hay silencio que no termine fits perfectly well within the current memory boom in publishing that has invaded the international cultural market. Aided by the protagonist's linguistic versatility and media personality, the release of No hay silencio covered a broad transnational market, which publishers certainly had anticipated. For them, the Betancourt story called out for a well-established international distribution network, and they managed to place it in mass media markets across the globe that enabled the "star hostage" to contextualize her captivity in the general interest that memory and testimony have generated in recent decades. ${ }^{12}$ Unlike the Latin American testimonial narratives of the 1980s, memoirs such as Betancourt's and those of her fellow hostages-Clara Rojas's Cautiva (2009) and Marc Gonsalves's Out of Captivity (2009)—, while still claiming "historical weight," were not primarily written to give voice to a communal struggle (e.g., that of those kidnapped or displaced by guerrilla forces); rather, they were constructed as individualistic accounts in which personal interests and emotions (and not collective suffering) took center stage. Lacking (for the most part) a reflection on Colombia's national crisis or even on the act of writing about captivity, these memoirs mainly re-familiarize readers with news media versions of the ordeal experienced by the FARC hostages in the jungle.

The appeal of these memoirs for popular cultural consumption can be surmised from the competing English subtitles employed to sell the personal narratives of Rojas, Gonsalves, and Betancourt: "2147 Days of Terror in the Colombian Jungle," "Surviving 1967 Days in the Colombian Jungle," and "My Six Years of Captivity in the Colombian Jungle," respectively. It is also important to note that both Rojas's and Gonsalves's memoirs were written by ghostwriters, thus placing the hostages' authorial (read authoritative) voice in question. For its part, the Betancourt memoir was written by herself in French and translated into English and Spanish. Rojas's memoir has a different subtitle in Spanish, 
Testimonio de un secuestro [testimony of a kidnapping], thus suggesting that her narrative sits alongside testimonial accounts, arguably within the Latin American tradition of testimonio. ${ }^{13}$

As pointed out by scholars in memory studies, mass media is now the omnipresent creative force in the global (re)construction of memory: "memory enjoys top billing in daily and weekly newspapers [as it] occupies us in our free time, in the form of a thriving industry" (Erll 1). The memory industry, which is largely based on the marketing operations of the media, presented Betancourt's memoir as a good product for consumers worldwide to read, and/or learn about through their television sets. One of the reasons why such media operations are so successful in the cultural market is that "we are not able to understand the past without media versions of it," representations which typically tend to dumb down the past while blurring the "divide between history and media" (Garde-Hansen 1-5). Therefore, as we rely more and more on the media to learn about the history of the FARC and Betancourt, we are also subjected to media processes of distribution and event selections in order to gain access to the "real history" behind the FARC hostages. This transformation of how we acquire historical knowledge has resulted, in many cases, in repositioning digital sources as our "primary access" to the past. In other words, "cultural memory is unthinkable without media" (Erll 113), since now individual and collective access to memory seems inevitably linked to media events or to the actual mediation of television and digital sources that process such memory. Our understanding of the national past is intimately linked to mediated accounts of war and atrocities through audiovisual exposure (be that print and television, film, photography, radio, or the internet) almost to the point that "we are not able to understand the past without media versions of it" (Garde-Hansen 1). This is due in part, according to José Van Djick, to media technologies that have reshaped the way in which both individual and collective memories are captured, what he calls "mediated memories," where "the personal and the collective interact" for the purpose of "creating and re-creating a sense of our past, present, and future selves in relation to others" (Loc. 170; Loc. 3304).

The Betancourt story illustrates the manner in which memory has been commodified through these technological changes to the point that it is unthinkable to talk about her captivity and release without referring to the fundamental role played by the news media outlets. In this regard, Nieger points that media memory is a field of inquiry that precisely address what kind of past, what version(s) of the past are re-created and shaped by different media, often underscoring the "cultures in which these processes take place" and "the interrelations between media and other realms of society" (2). And, as Nieger reminds us, "collective memories do not exist in the abstract [...] there can be no 'collective memory' without a public articulation [...] in short, collective memory is an inherently mediated phenomenon" (3). Furthermore, the mass media's hold on 
the Betancourt story gives social and historical relevance to the role of digital technology in creating cultural memory since "personal memories can only gain social relevance through media representation and distribution" (Erll 113). No hay silencio is an example of these mass media processes of historical memory as its main focus rests on a personal recollection of key moments in Betancourt's captivity in the jungle, most of which had already been reported by the media prior to her liberation. The event selections in her memoir follow information patterns similar to those often provided by the news media, which, overall, tend to be spotty and rarely provide a continuously cohesive narrative. This selective process can be seen as related to forgetting, which "is necessary for memory to operate economically" and inherent in remembering (Erll 8).

Betancourt's memoir jumps back and forth through 82 episodes arranged in a non-chronological order, as she tries to reconstruct her almost untraceable path in time and space across the jungle. ${ }^{14}$ It is precisely under the umbrella of the Amazon rainforest that the comings and goings of the protagonist are reported without giving readers a sense of spatial direction. This is an intentional move designed to have her readers "lost in the jungle" as they go alongside her journey and shared kidnapping victims' lack of access to spatial orientation while in the jungle. And it is indeed one of the appeals of the book: to place international audiences in the skin of Betancourt as if traversing the Amazon jungle together with her. As revealed toward the end, Betancourt's presentation of spatial and geographic environments where she suffered atrocities and humiliations is highly consistent with the tradition of novela de la tierra-Latin America's regionalist literature in the early 20th century: "Nos internamos cada vez más en las profundidades de la selva" [We penetrate more and more into the depths of the jungle (Betancourt, No hay silencio 503)]. Veiled references to José Eustasio Rivera's 1924 novel La vorágine [The Vortex] such as the latter abound in Betancourt's No hay silencio (for instance, 447-448; 503; 562; 599) to show how the jungle overpowers human existence. This is one of the premises of the so-called novela de la tierra, which in the captivity memoir is nicely tied to the imaginable as real: "en Colombia lo real desborda las fronteras de lo posible. Los límites con lo imaginario son difusos y todo coexiste con la mayor naturalidad" [in Colombia, the real goes beyond the boundaries of the possible. The limits with the imaginary are blurred and everything coexists naturally] (476-477). ${ }^{15}$

That said, the suffocating presence of the jungle finds a "clearing in the forest" toward the end of the text, where more concrete spatial references are given to locate the FARC camp in which the protagonist is being held. On page 516 (out of the 708 pages in the book) Betancourt provides-for the first time in the book-a specific location in a reference to Guaviare, the department where she was captured. This reference also gives readers a location in which to situate the captivity narrative. Interestingly, the almost exact location is provided thanks to the alleged neglect of her 
captors (in line with the FARCE portrayal in Ingrid de la jungle) who inadvertently left a GPS device in the hands of Betancourt:

De modo que estábamos aparentemente en el Guaviare, al norte de Mitú, la capital de Vaupés, el departamento limítrofe del Guaviare al sur, y cerca de Guainía, con el que limitaba el oriente.

So we were apparently in the Guaviare, north of Mitú, the capital of Vaupés, the adjacent department to the south of Guaviare, near Guainía, with which it borders to the east.

As a reminder that in the jungle one loses the notion of time and space, it is not surprising to find many references in No hay silencio to temporality as a key factor in the hostage's process of reconstruction of memory. For instance, the notion of time is something Betancourt reiterates especially after her failed attempts to escape:

el tiempo había dejado de ser lineal; se había vuelto permeable como un sistema de vasos comunicantes. El pasado regresaba para ser revivido como proyección de lo que podría volver a ocurrir.

time had ceased to be linear; it had become permeable like a system of communicating vessels. The past returned to be re-lived as a projection of what might happen again.

It is true that the loss of time and omission of specific geographical space up to this point (around 2005 in Betancourt's narrative) are part and parcel of her interest in presenting the jungle to us as a powerful enemy that she describes as "un campo de concentración tropical" [a tropical concentration camp] (424). Using the specter of the Holocaust (a key point of reference for memory and trauma studies), Betancourt seeks to strengthen her survival story before international audiences who may not be well versed in the Colombian geography, thus underscoring the "dark exoticism" that even today is identified as typical of Latin America. But geographical displacement also helps create a sense of disorientation in readers-one that emulates the dislocation felt by Betancourt during most of her own captivity in the jungle. Alongside the temporal displacement of her account lies the spatial displacement of a tropical concentration camp.

Such spatial and temporal considerations are important for the reconstruction of memory and, ultimately, for the memoir's ties to historical memory and Latin American testimonio. While Betancourt's text does not fit fully into any of these generic parameters, it does fit well with the contemporary interest in investigating the processes of historical 
memory, as it explores questions of temporality in the reconstruction of a personal (not collective) memory. Likewise, publishers have promoted the Betancourt story as belonging to two predominant modes of reconstruction of the past: historical memory and testimonio. These, in my view, have been reshaped by the incursion of mass media in our understanding of historical events and by its constant (almost 24/7) mediation of our past and present via television, newspapers, radio, and the internet. But, unlike the communitarian vision in the classical texts of Latin American testimonio_such as Me llamo Rigoberta Menchú y así me nació la conciencia (1983) or "Si me permiten hablar", testimonio de Domitila, una mujer de las minas de Bolivia (1979)_, Betancourt's text is mainly concerned with sharing a personal story of survival:

Escribir este libro me obligó a sumergirme profunda e intensamente en mí misma y en mi pasado, trayendo desde ese fondo abismal, un caudal de emociones desbocadas.

Writing this book forced me to dive deeply and intensely into myself, bringing out from that abysmal bottom a flow of unbridled emotions.

Thus, Betancourt does not seek to give voice to a collective-be that of the hostages of the FARC, or more generally, of those who are deprived of their liberty-or even to situate herself or her story in the context of other written forms (journalistic accounts, investigative reports, memoirs) that recount the violence in Colombia as experienced by the victims of kidnapping, drug trafficking, and displacement.

For John Beverley, one of the key features of testimonio is the urgency to communicate "a problem of repression, poverty, subalternity, imprisonment, or struggle for survival," and the presence of a narrator who "speaks for and in the name of the community or group" (30-33). This point is paramount when seeking the connections between the genre of testimonio and other related narrative genres such as memoirs, confessional diaries, or even the testimonial novel. The fundamental differenceBeverley reminds us-is that in testimonio the narrator, by giving voice to a community, breaks his/her "hierarchical and patriarchal status" and thus erases the role as the sole authority in the text; that is to say, testimonio advocates for the dismantling of the "authorial presence" in favor of a collective voice representing a group or a specific social struggle. In this regard, unlike the mediating role of Elisabeth Burgos in Menchú's testimonio or Moema Viezzer in Domitila's narrative, in Betancourt's account there is no alternation or switching of the "I" narrator's role; it cannot be assumed indiscriminately by any of the affected people in her group of hostages or even in the large community of the displaced in Colombia (Beverley 40-41). ${ }^{16}$ The narrative "I" is Ingrid, the illustrious hostage exalted by the media who often appears remote and oppositional 
in relation to her fellow captives. Her community or collective remains "silent" and "absent" throughout No hay silencio que no termine.

As suggested by this chapter's title, the Betancourt story serves to illustrate a different brand of memory making, a memory in "show time" or a "memory in the times of mass media." Despite these incursions or points of contact with memory and testimony, the Betancourt story, the book release, and the media frenzy around her abduction undermine any resemblance to collectivity offered by anthropologists and historians during the boom of testimonio in the 1980s. The Betancourt story is therefore a beneficiary of the memory boom in the times of media, which, as suggested by the comic Ingrid de la Jungle, often seems to be a plausible, in-progress reality show about surviving in the Amazon rainforest starring Ingrid herself. All this does not detract from the hardships endured by the FARC hostages, but perhaps it is a sad reminder of the uses and abuses arising from the processes of global cultural production and media branding in the times of memory.

\section{The Betancourt Story Spins Off: Captivating Stories in Operación Jaque and Operación E}

The culture industry quickly (and aptly) diversified its portfolio for the Betancourt story. As expected since her liberation, Betancourt's survival story and spectacular rescue operation soon reached the big and small screens, as anyone could have predicted from watching the media circus that surrounded the FARC hostages release in July 2008. Two international film productions (one made for TV, the other one for the big screen)—Operación Jaque (2010) and Operación E (2012)—captured precisely the media's impact in recreating the past with respect to the memories left behind in the jungle by Betancourt and her political partner Rojas, whose friendship did not survive their captivity. These two productions are primarily constructed to rehash familiar events of the FARC hostages' stories by presenting their most captivating episodes such as the kidnapping and liberation, the fate of Rojas's child born in captivity, and Ingrid's confrontations with fellow hostages and captors. These film versions of FARC hostage taking, in which personal struggles are emphasized over collective conflict and "gossipy elements" over sociohistorical reasons for the hostage crisis, are mainly made to re-familiarize international audiences with the media version of the Betancourt story. As a result, both film productions reinforce the historical amnesia-"a culture that is terminally ill with amnesia" (Huyssen, Twilight Memories 1) - that is behind most media accounts of personal survival and struggle, often leaving aside the kind of political and collective reflection required for the construction of Colombia's national memory. Unsurprisingly, the marketing of Operación Jaque and Operación E seeks precisely to give the opposite impression, as producers and filmmakers insist that their 
films relate "real events" and introduce us to the "real history" of the FARC hostages in the jungle.

To achieve this result, the media promotion of Operación Jaque, for instance, relies heavily on the fact that the series was shot over a ten-week period on location in the Colombian jungle (Cumaral, Meta-to be precise), placing the actors (and those involved in the making of the series) in close proximity to the "authentic" experience of the FARC hostages (as Ingrid de la jungle tried to emulate). ${ }^{17}$ For its part, the marketing of Operación E, as spelled out in the movie poster and DVD cover, insists that the film is based on "hechos reales" [real events]; it is a story about "la liberación de un niño" [the liberation of a child] and "la paz de un país" [the peace of a country]. In the context of marketing and distribution, it is also important to keep in mind that both films are international co-productions (Spain, Colombia, France) with wide distribution in media markets that roughly correspond to the circulation patterns of Betancourt's No hay silencio, which was released almost in synch with the television series Operación Jaque and news of Betancourt's lawsuit. Needless to say, these coincidental media events in the months prior to the release of her captivity memoir (July-September 2010) added significant weight to the international interest in the Betancourt story, providing cultural consumers with an array of products (television, film, book memoir, and comic book) from which to experience memories of struggle and survival in the jungle. The posters for Operación Jaque and Operación E point to these dramatic overtones as we can see hostages on the run and being taken into custody by the guerrillas (Figures 2.3 and 2.4).

The series Operación Jaque was commissioned by Spanish TV from a Colombian production company (Paraíso Films) and released on July 20, 2010, almost exactly three months before the official launching of No hay silencio (September 21, 2010). As is common practice, Operación Jaque was broadcast differently in Spain and Colombia according to consumer viewing habits in Europe and Latin America. The mini-series version premiered in Colombia in July 2010 (Caracol TV) and in Spain (RTVE) in August 2010, and was then rebroadcast as a 15-episode series in December 2011, thus adjusting to television watching habits in Latin America, where brief episodes (20-30 minutes) with cliffhangers are the preferred format to secure continued viewing. Regardless of the format, Operación Jaque-following (closely) Juan Carlos Torres's book Operación Jaque (2009)—offers a condensed version of the six-year span in which Betancourt remained a captive, and is organized in chronological order so as to build up the grand finale of her liberation and the (apparent) triumph of Operation Checkmate. ${ }^{18}$ Torres's fictionalized investigative report claims that on April 29, 2007, a Colombian intelligence operative managed to locate the coordinates for the FARC hostages in the jungle, which were then used to create a false communication scheme between the commander at the hostage campsite ("César," alias 


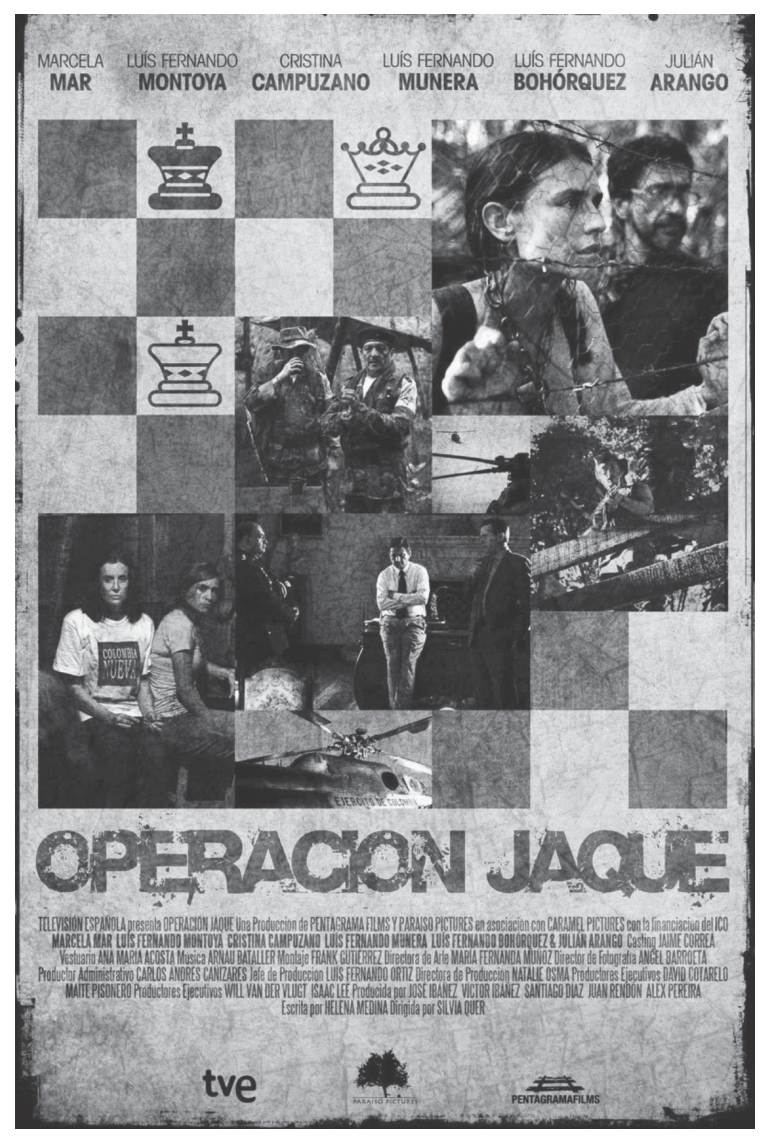

Figure 2.3 Operación Jaque, TV series poster, RTVE, Caracol TV.

of Gerardo Aguilar Ramírez) and the FARC headquarters ("Alfonso Cano," nom de guerre for Guillermo León). Once the so-called "electronic deceit" (Torres 80) was set up, the Colombian intelligence (apparently) managed to communicate freely with the FARC camp and planted the idea of a humanitarian mission to transport the hostages to another FARC location. It would take-according to Torres's book and the television series-almost a year to train the intelligence operatives who participated in the humanitarian NGO scheme. Thanks to acting lessons, self-defense training, and many hours of rehearsals, the so-called Misión Humanitaria Internacional was to replicate in its members other humanitarian missions that had successfully interacted with the FARC. Thus, it was decided that the Misión would include "a leader, a doctor, two nurses, an Australian and an Arab delegate, one journalist, a camera reporter, a FARC member with close ties to Alfonso Cano, and a FARC 


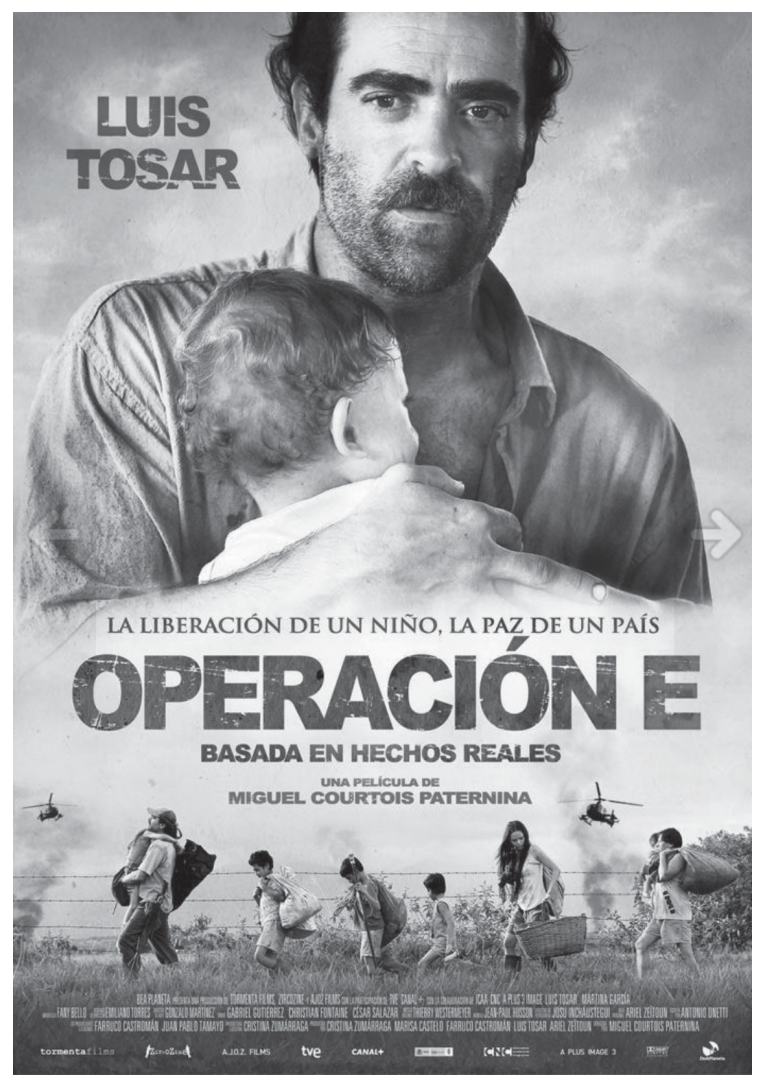

Figure 2.4 Operación E, movie poster, RTVE, Canal +.

member from the Bloque Caribe" (Torres 154). Indeed, the undercover operation had from its inception all the makings of a great filmic production, and this is precisely what the media and the series have so well capitalized on in order to capture their audiences.

Operación Jaque centers its narrative-as one would expect from media accounts-around the omnipresent figure of Ingrid Betancourt, who is often portrayed as a self-entitled, (at times) feisty, and (very often) opinionated hostage. Operación Jaque sets the tone for the protagonist right from the moment in which Betancourt and Rojas encounter the FARC in San Vicente del Caguán: "\{Ingrid\}: ¿acaso usted no sabe quién soy yo?" [perhaps you don't know who I am (emphasis in the original)]. Betancourt's status as a "star hostage" is felt throughout the entire series and is duly recognized by the FARC, who see in her "una moneda de cambio" [a bargaining chip], and the Colombian officials who want to take that chip away from the guerrilla. More importantly, though, the proposed reconstruction of Betancourt's captivity in Operación Jaque 
seems geared toward repairing her damaged public and media persona after the lawsuit fiasco, and to this end, the series repeatedly tries to "humanize" the protagonist as simply a victim of kidnapping and captivity. To achieve this, the series foregrounds the rather amicable interaction between Betancourt and Rojas; for example, their separation is presented as a highly melodramatic point of the story (Part 1; 1:03:00), and emphasized the ruthless beating Betancourt endures after one of her escape attempts (Part 1; 1:11:00), as well as the tear-jerking moments when she hears her children on the radio or learns of her father's death through an old wrinkly newspaper. ${ }^{19}$

Furthermore, the series justifies some of Betancourt's questionable behavior (toward fellow hostages and guerrilla members) when she is given a chance to offer her reflection on their shared six-year captivity just as the rescue plan is underway: "todo lo que se vive en esta selva debe quedar enterrado en ella para siempre" [all that has been lived in this jungle must remain buried in it forever (Part 2; 0:09:00)]. This lapidary statement, which seems to have been taken almost verbatim from José Eustasio Rivera's 1924 novel La vorágine, foreshadows "post-liberation" Betancourt's media appearances that rationalize her actions under FARC captivity as collateral jungle damage not to be fully disclosed. The aura of mystery thus continues to permeate the series' take on the FARC hostages in conformity with the view that things ought to remain "buried" in the jungle, or, at least, not fully clarified. The series' last frames show the empty helicopter used in the rescue operation with some captions announcing that all those involved in Operación Jaque are now in the US under government protection, and that the FARC leader (César) responsible for the "unfortunate" hostage handover is also in the US serving a conviction for drug trafficking, according to the official version of the events (Part 2; 1:17:00). The ending, in other words, suggests that there is a sequel here to be made and that the Betancourt (media) story is "to be continued."

The film Operación E (2012) is a case in point. It is a French-Spanish co-production that recounts the story of Clara Rojas's son's journey from captivity with the FARC to a foster home in a farm in guerrilla territory, and functions as a prequel to Operación Jaque. ${ }^{20}$ Since by 2012 the Betancourt story appeared to have lost momentum, with Betancourt out of the picture in Europe, working on her doctoral degree in theology at Oxford and writing a novel in French and Clara Rojas having regained custody of her lost "jungle child," Operación E, in effect, kept the Betancourt story (once more) alive and in the media. While not directly concerned with Betancourt or Rojas or their falling out in the jungle, the movie reconstructs Rojas's survival and hostage release through the story of her child Emmanuel. It is again a story cut out for the media in that it is replete with deceit, an unwanted pregnancy in the middle of the jungle (resulting from a relationship with an unnamed member of the FARC guerrilla) and a convoluted (and Hollywoodesque) story 
concerning the search for a lost child who was used as a bargaining chip for Rojas's release from the FARC, which occurred only a few months before Betancourt's liberation in 2008.

What interests me about this film is not so much its melodramatic overtones, which at times recall a made-for-TV movie of the kind "I want my child back!"; rather, I am interested in the film's use of memory and historical reconstruction being employed to tell the story of José Crisanto Gómez Tovar-the farmer whom the FARC forced to be the caretaker of Emmanuel Rojas. The movie, as one would expect, has a companion in the book El hijo de la selva [the son of the jungle], a memoir written by Crisanto Gómez while incarcerated on charges of kidnapping and collaboration with the guerrilla. ${ }^{21}$ As we are reminded from the opening credits, this is not just a personal story, but one for the national collective memory concerning an episode that was closely followed by the news media, the FARC negotiators, and the Rojas and Betancourt families. A series of closeup shots in the film indicate precisely those moments in which memory is (re)constructed for the audience and, in turn, for the national collective. The opening image, for instance, presents a closeup shot of Crisanto (played by Luis Tosar) talking directly to the camera and announcing: "Les voy a contar todo, todo lo que sé" [I am about to tell you everything, everything I know]. With this statement, Crisanto begins to reconstruct the memory of Emmanuel (and the involvement of the FARC in his kidnapping) as he had testified before government officials.

After a five-minute steady-camera closeup of Crisanto's face, the film backtracks to the day when the FARC handed him over an eight-month baby with a broken arm and severely bitten by mosquitoes. No name or other information is given to him by the FARC; he is simply to follow their orders and keep the child under his care at his farm without asking questions. It seems that the baby boy's precarious health is of concern to the FARC and, given that Crisanto's father-in-law is a local healer, the guerrilla decided to leave the child under the care of the Tovar family. But, against FARC orders, and in view of the baby's deteriorating condition, Crisanto decides to secretly take him to a hospital, where the child is understandably "flagged" as a possible victim of child abuse and is ulti-mately taken into state custody (and, as we later learn, into an orphanage). Crisanto, not quite understanding the involvement of child services in his removal of the care and custody of Emmanuel, is advised by legal counsel to hand the child over to the authorities with the promise that he may claim custody at a later stage, once the child's wounds have healed. But things get complicated. Soon he realizes, watching television and reading a newspaper, that Emmanuel is at the center of the brokered negotiations between the FARC and Venezuelan and Colombian authorities to release Clara Rojas. Two closeup shots in which Crisanto's face and the newspaper split the frame are used to explain how he comes to the realization that the child once under his custody actually belongs to Rojas. In these two parallel shots, the news about "Operación Emmanuel" 


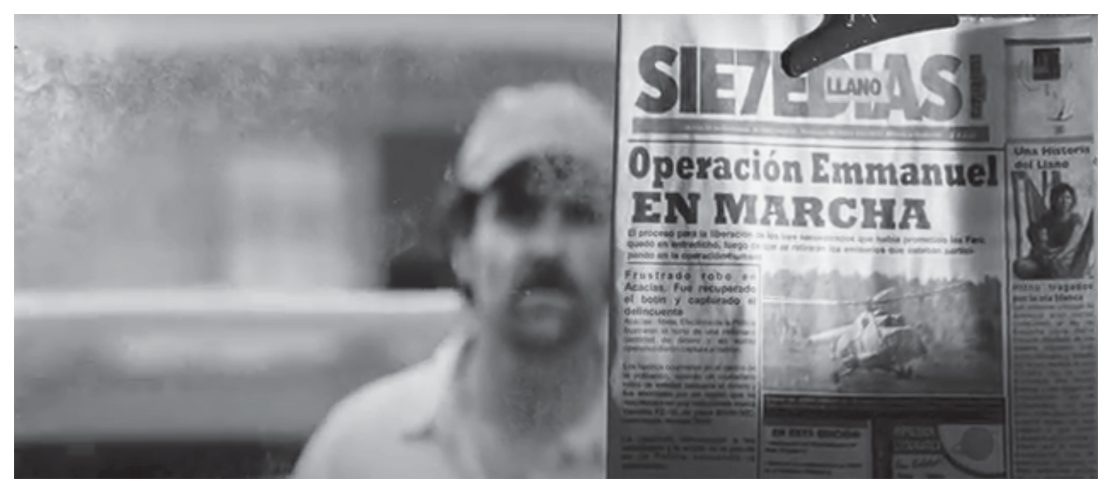

Figure 2.5 Crisanto in Operación E (screenshot; newspaper closeup).

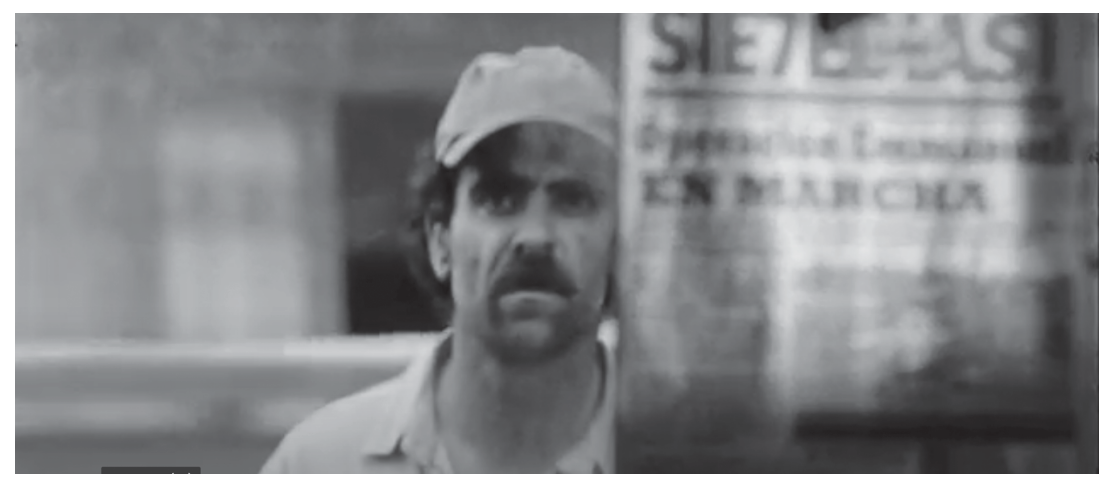

Figure 2.6 Crisanto in Operación E (screenshot; face closeup).

and Crisanto's face blur in and out in a matter of seconds, foregrounding the newspaper in the first shot and Crisanto in the second (Figures 2.5 and 2.6).

This marks the moment in the film when it becomes clear to Crisanto, from the news media description of the child's ailments, that he was the foster parent of the FARC's "jungle child" (as the real-life Crisanto will name him in his personal memoir). These shots, as it were, trigger the memory of Emmanuel in Crisanto even as they reconstruct this instance for the audience and for the national memory. But, as I have pointed out in this chapter, it is similarly through television and print media (e.g., those closeups of the newspaper) that the memory of FARC's hostages (Rojas's child among them) comes into being, not only for their protagonists, but ultimately for the nation.

Pairing together the filmic operations in "Jaque" and "E," we see that, in the case of Colombia, memory and the reconstruction of the national 
past can occupy a central role in memoirs, television series, and movies that are often themselves produced outside Colombia. In this regard, the Betancourt story performs a double-duty function for the culture industry as it responds both to the memory boom cash-cow and to the desire for cultural consumption of Colombian stories of violence, survival, and personal struggle. All of which is possible thanks, in part, to the existence of memories shared by global readers, television viewers, and filmgoers, in which the Betancourt story continues to hold a significant place. But, just as we all thought that the Ingrid Betancourt story had been exhausted, and had perhaps sunk into oblivion, the cultural market embarked on a new venture (of the literary kind) to restore it to prominence. In 2014, Betancourt published in French the novel La ligne bleue. Set in 1970s Argentina during the harsh years of the military junta, it tells a love story involving a leftist guerrilla fighter and a woman who has the magical power to see the future. According to the French publisher (Gallimard), the novel touches upon several themes (freedom, personal courage, hope) that appear in Betancourt's captivity memoir and that recur in a different historical setting. The novel, not yet published in Spanish, has been translated into Portuguese (A linha azul) and published in Brazil (Alfaguara 2015), and into English (The Blue Line) published by Penguin in 2016. Heralded by this latter publisher as "a breathtaking story of love and betrayal by one of the world's most renowned writers and activists" and "a deeply felt portrait of a woman coming of age as her country falls deeper and deeper into chaos," the imminent launching of The Blue Line returned us once more to cultural practices of memory in the times of mass media. ${ }^{22}$ And, in so doing, it revived the Betancourt story for global audiences one more time.

\section{The "Official”" Memory in Colombia}

In counterpoint to the memory that I ascribe to the Betancourt story, it is important to situate the efforts made by Centro Nacional de Memoria Histórica (CNMH, National Center for Historical Memory in Colombia) - particularly with the publication of the report ;Basta ya! Colombia: memorias de guerra y dignidad [Enough is Enough! Colombia: Memories of War and Dignity] (2013), a 400-plus page comprehensive account of violent acts against the civil population in Colombia. The Center's creation in 2011 was an important milestone in the Colombian government's efforts to bring some closure to the violent acts committed by guerrillas, paramilitaries, and others who took advantage of the status as a "failed state" in which Colombia has been immersed since the 1950s. Following a series of laws and decrees issued between 2005 and 2010, the so-called Research Group for Historical Memory (Grupo de Memoria Histórica) was in charge of compiling the report under the leadership of Gonzalo Sánchez Gómez, then director of the Center for Historical Memory. ${ }^{23}$ 
The report received only modest attention from the international media despite its importance and research quality. Notwithstanding the scant media attention (if one compares it with the Betancourt story), it does offer us a detailed reflection on what it means to reconstruct the Colombian national memory of the past 50 years on the basis of extensive testimonial and historical documentation. In this regard, it is very significant that, while Betancourt's captivity narrative chooses not to explore collective memory-i.e., to reflect on Colombia's national memory (or on the FARC hostages as a group engaged in a common struggle)-, $i$ Basta $y a$ ! repeatedly explains its position vis-à-vis the discourses of memory reconstruction in an effort not only to collect testimonies of violence and displacement in Colombia in the past five decades but also to detail the significance, in itself, of the act of (re)constructing a national memory. It is hard to disentangle these governmental efforts from their media reception, since memory centers are accountable for their findings before the public at large. It is often the case that their findings are widely circulated through television and print media. In the international media reception of iBasta ya!-of course, much less glamorous than the international launching of No bay silencio-, these reflections on the construction of memory and its importance for the report and for Colombia were not mentioned. ${ }^{24}$

A companion initiative led to the inauguration of the Centro de Memoria, Paz y Reconciliación (CMPR, Center for Memory, Peace, and Reconciliation) in the Parque El Renacimiento in Bogotá, a space designed to contribute to the reconstruction of historical memory in Colombia. In line with what we have seen in other Latin American countries, the proliferation of memory centers and sites for memorializing the atrocities committed under dictatorial regimes has mushroomed all over the continent. But, unlike other reconstructive processes of the "national historical memory" in Chile or Argentina, Colombia presents a unique case in that atrocities have continued there under a solid history of democratically elected governments. The non-cessation of violence in Colombia since the 1950s has created all sorts of difficulties in reconstructing a national memory for a country still immersed in combat-the killing of more than 1,000 social leaders since the signing of the Peace Accords in 2016 is a case in point. ${ }^{25}$

When one visits the Centro de Memoria, Paz y Reconciliación (like I did for the first time in 2014), it is striking to see the peripheral location of the site, next to Bogotá's Central Cemetery and relatively far away from the city center's tourist attractions (e.g., the Candelaria district and its cathedral, the Botero Museum, and Museo del Oro). And while the CMPR's building and adjacent structures are fairly modern with an innovative architectural design that includes a reflecting pool, the entrance to the building makes one wonder about the "peripheral" placement of memory, peace, and reconciliation in Colombia. Only a few years after its inauguration, the building's sign literally shows damage to 
the word "memoria," as the second " $m$ " appears to be missing a piece, which is very telling of the overall conditions surrounding the Centro's location (including homelessness, as can be seen in Figure 2.7). This, of course, does not take anything away from the Centro's mission:

Contribuir a la construcción de paz, con la participación de los distintos sectores poblacionales de Bogotá a través de la promoción $\mathrm{y}$ fortalecimiento de procesos de memoria que visibilicen las distintas experiencias relacionadas con el conflicto armado.

To contribute to building peace with the participation of different populations in Bogotá through the promotion and strengthening of memory processes that give visibility to different experiences related to the armed conflict.

(http://centromemoria.gov.co/informacion-general/)

It is indicative, though, of how "official memory" centers operate as nonthreatening entities to the State, as places in the margins that, ultimately, leave the State "immunized" from past atrocities.

Despite this, CNMH and CMPR brought collective memory to the attention of media outlets with varying degrees of interest and

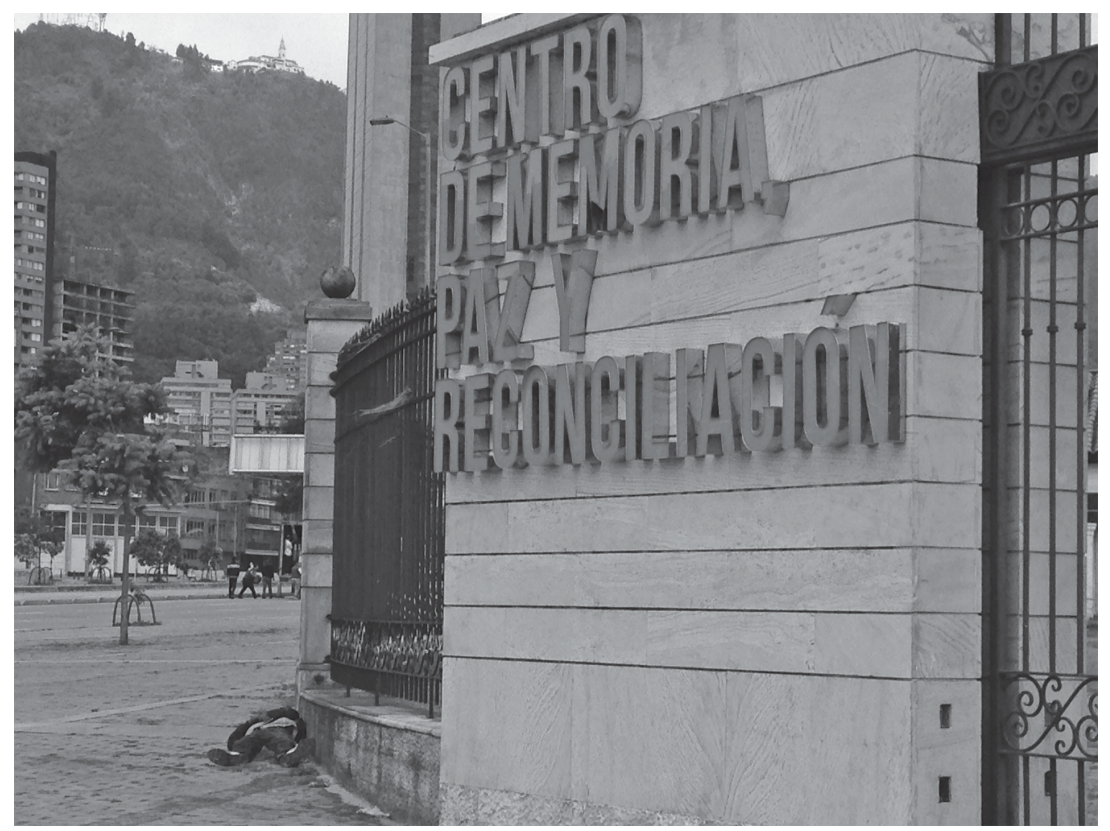

Figure 2.7 Centro de Memoria, Paz y Reconciliación. Photograph by the author (2014). 
engagement, and, in some ways, contributed to refocus the national discussion from murders, kidnappings, and drug trafficking toward a national healing process, which, of course, is still ongoing. But this collective effort to bring about a national historical memory through "official" centers is also subjected to cultural commodification. In this regard, Sven Schuster takes Pierre Nora's assertion that "collective memory no longer exists" to explain that societies under transition (like Colombia) present a weaker connection "between the living, collective, and national memories," which lead to building sites of memory as artificial placeholders for the now-absent collective memory" (40). Although the case of Colombia is significantly different in terms of length of time and warfare participants (e.g., guerrillas, paramilitaries, drug lords, the army), we have to take into account that historical memory in Latin America (and also Spain) has also become a widely distributed cultural commodity in film, art, literature and other means of cultural dissemination. For example, Michael Lazzara has pondered how much and what kind of memory is most appropriate in the aftermath of atrocities, and, more importantly, who is authorized to speak about the past (10). And scholars of historical memory in Spain, an important point of reference for similar processes in Latin America, have investigated the dynamics established by processes of oblivion and cancellation of memory in (post) Franco Spain, which have resulted in a "history as trauma" or a "wounded memory" (Moreiras-Menor 121-122).

For Jeffrey Olick in The Collective Memory Reader, government initiatives such as the ones we see in Colombia are indicative of a current trend, in which "nation-states turned to the past as a basis for shoring up legitimacy," the result being "a commodification of nostalgia," the "popularization of history," and a shared interest in "collective and individual memory" (3-4). As a consequence, memory studies as a discipline can be understood within the broader context of the memory industry, which we consume through social networks and media. No doubt, official memory centers such as the ones in Bogotá seek to expose the atrocities committed against a nation's citizens. However, their efficiency has been questioned by Tzvetan Todorov in Memory as Remedy for Evil (quoted in iBasta ya!), where he argues that, while testimonio and confessions act as necessary catharses involving the recognition of victims and the exposure of crime offenders, these testimonials per se do not deter further atrocities and, therefore, are proven to be somewhat defective (8-50). In line with Todorov's critique of "memory for memory's sake" (he advocates action beyond simply collecting data and gathering testimonials), Andreas Huyssen falters the modern media and its numbing reproduction of memory as responsible for "a saturation in the marketing of memory" and the ensuing "hypertrophy of memory." 26 Since the past sells "better than the future" we are faced with a re-evaluation of the significance of media-based memory and the 
commodification of testimony, memoirs, and confession for the purpose of media coverage and market distribution: "memory discourses themselves partake in the de-temporalizing processes that characterize a culture of consumption and obsolescence" (Huyssen, Past Presents 10). This poses a series of questions about whether governmental entities devoted to memory respond to the marketing of memory, or whether historical memory can indeed be attained independently of mass media operations.

These considerations notwithstanding, I find it fruitful to consider the findings and the work coming from these official memory centers as themselves driven by the cultural market and the media. In reading closely ¡Basta ya!, questions about the report's own involvement, reception, and distribution (basically, who's reading this report or for whom it is being written) constantly surface. But these issues are not really fully addressed by the report's compilers. That said, the report does not look the other way when it comes to self-reflection about writing the national historical memory. In this regard, I find it somewhat surprising that, while ¡Basta ya! originates from a governmental entity and therefore arouses an expectation to read mere officialese, its initial pages reflect-albeit timidly-on some of these key questions about the process of writing Colombia's national memory.

Faced with this task, the report's compilers state in the "Preface":

elinforme no es una narrativa sobre un pasado remoto, sino sobre una realidad anclada en nuestro presente. Es un relato que se aparta explícitamente, por convicción y por mandato legal, de la idea de una memoria oficial del conflicto armado.

the report is not a narrative about a remote past, but about a reality anchored in our present. It is a story that explicitly sets aside, by conviction and by legal mandate, the idea of an official memory of the armed conflict.

In their view, there is a clear distance to be established between what officials (and, arguably, the news media) want and their own task at hand, which is to "actualize" (to bring to the present) the memories of those who have suffered Colombia's armed conflict. Interestingly, despite its governmental sponsorship, the report offers its own understanding of historical memory within the context of what Huyssen would call "cultural amnesia," as the report states: "Colombia sufre de mala memoria, pues aprovecha y aprende poco de sus experiencias y errores" [Colombia suffers from bad memory, because it fails to learn from its experiences and failures] (iBasta ya! 24). Furthermore, in addition, the report does not fall short when it comes to detailing its own intentionality vis-à-vis 
the reconstruction of this national "bad memory." It concludes its initial section by asserting that:

Hacer memoria de la violencia es también hacer memoria de los cambios indeseados, de los seres, de los entornos, las relaciones y los bienes amados que fueron arrebatados. Memoria de la humillación, del despojo, de los proyectos truncados. Memoria de la arbitrariedad y de la ofensa. Memoria del enojo, de la rabia, de la impotencia, de la culpa y el sufrimiento ... Estamos en tiempos de memoria, pero la reconstrucción apenas comienza.

Remembering violence is also to recall the unwanted changes, the human beings, the environments, the relationships, and the beloved possessions that were taken away. To recall the humiliation, dispossession, and unrealized projects. To recall the arbitrariness and offense. To recall the anger, rage, helplessness, guilt, and suffering ... We are in the times of memory, but reconstruction is just beginning.

(25-26; my emphasis)

This lengthy listing of memory's entitlements illustrates the context in which the report is written and will be read-i.e., the times of (media) memory. ${ }^{27}$ It is within that context that one has to understand iBasta ya! as an exemplary case of the media exposure that has helped propel the reconstruction of (official) historical memory in Colombia. In this regard, the CNMH's role as an official outfit in charge of documenting and collecting the voices of the past, and "preserving" the memory of those who suffered atrocities during the conflict raises a series of questions about the State's involvement and participation in historical memory. ¡Basta $y a$ ! clearly identifies the State as one of the perpetrators in the armed conflict, despite the fact that the State itself is providing the operational and logistical support necessary to reconstruct the "official" historical memory. Clearly, this is evidenced by CNMH's prolific publication and documentation program. Since 2008 the Centro has published 150 books and created documentaries and podcasts that cover a large geographical and thematic sample of the Colombian conflict-some books are specifically devoted to locations where infamous massacres occurred such as El Salado, Bojayá, La Rochela, San Carlos, El Tigre, or Trujillo. Other publications tackle broader questions concerning justice, peace, women's rights, the LGBTQ community, urban warfare, and exile. This inclusive approach on the part of the Centro opens up new interpretations of the history of conflict in Colombia, as victims' voices are given a space to be heard, particularly those who have typically been silenced-e.g., farmers, indigenous groups, Afro-Colombians, displaced women, and members of the LGBTQ community (Ospina, El rompecabezas 23). What remains unclear, though, is how big a reach and what kind of impact this vast documentation has had on the general population in terms of reconciliation 
efforts, particularly when considering that all Centro's publications are accessible on its website for free download and viewing. ${ }^{28}$

But this "official" (and extensive) memory remains always incomplete. In "Construyendo memoria en medio del conflicto," Pilar Riaño and María Victoria Uribe (who participated in the Grupo de Memoria Historica) advocate for an integrative model in the reconstruction of memory that gives voice to victims, victimizers, and social organizations since, in their view, there is no possibility of one "single" truth about the Colombian conflict. Their work in the Grupo sought to document different "repertoires of violence" (repertorios de la violencia) in the Colombian conflict, including displacement, land grabs, kidnappings, and gender-based abuses. But, as expected, in many instances this proved to be a difficult task since, for many victims, their own personal security could not fully be guaranteed if they spoke about the events they had witnessed or experienced. For this reason, Riaño and Uribe acknowledge "silences in the victims' memories" as one of the pending matters in the Grupo's efforts to "incorporate dissident and independent voices" in what they call "a non-governmental memory" (19-20). This obviously raises some doubts about the role of government in creating an "official" memory that can be as integrative as the Grupo's aims indicate, and, furthermore, questions the reconstruction of Colombia's historical memory when the wounds are still fresh and the hostilities continue as attested by the ongoing killing of union and social leaders.

\section{Notes}

1 Frederich Blassel for RSR (Swiss public radio) was the first one to report the ransom story on July 4, 2008, only two days after Betancourt's liberation. This news coincided with Betancourt's visit to Paris, where President Sakorzy welcomed the illustrious Franco-Colombian hostage to the Elyseé Palace. For a sample of the international media coverage of the ransom claim, see, for instance, The Guardian (July 4, 2008, www.theguardian.com/world/2008/jul/ 04/betancourt.france); BBC Radio (July 7, 2008; www.bbc.co.uk/worldservice/ news/2008/07/080708_betancourt_sl.shtml); Le Figaro (July 8, 2008; www. lefigaro.fr/international/2008/07/04/01003-20080704ARTFIG00425-millions-de-dollarspour-liberer-betancourt-.php). See also J.G. Ortiz Abella's Operación Jaque: secretos no revelados.

2 Until Death Do Us Part was originally published in French as La rage an coeur (2001) and in Spanish as La rabia en el corazón (2002). It is very telling that the English version Until Death Do Us Part was republished soon after Betancourt's release with a shining label across that read "Kidnapped on February 23, 2002. Rescued on July 2, 2008.”

3 Despite the vast scholarship on memory, only a few studies tackle the relation between media and memory, in particular, how media defines or constructs individual and collective memories. I draw primarily on Motti Neiger's (et al.) On Media Memory (2011), José Van Djick's Mediated Memories (2007), and Astrid Erll's Memory in Culture (2011). For a general discussion on personal and collective memory, and the history of memory studies, see Paul 
Ricoeur's History, Memory, Forgetting (2006), Katherine Hodgkin's Regimes of Memory (2003), and Jeffrey Olick's The Collective Memory Reader (2011). In the context of Colombia, I refer to Marías Ospina's El rompecabezas de la memoria (2019), Alejandro Castillejo's Vilolencia, memoria y sociedad (2013), Óscar Acevedo Arango's Geografías de la memoria (2012), Daniel Pécaut's La experiencia de la violencia: los desafîos del relato y la memoria (2013), Sven Schuster's “The Duty of Memory” (2017), and Pilar Riaño's and María Victoria Uribe's “Construyendo la memoria en medio del conflicto” (2017).

4 There is very little information about the actual print run for the comic book or the audience reached when it was first released. Generally speaking, Mark McKinney points out that the distribution of French-language comic books is typically quite ample since these books

are sold in a variety of ways, including through: hypermarket chains,
such as Carrefour, Intermarché, or Leclerc, which sell both food
and dry goods; high-volume, general bookseller, and multimedia
chains, especially the FNAC in cities throughout Belgium, France,
and Switzerland [...]; generalist bookshops and newspaper/magazine
shops [maisons de la presse]; and specialized, independent comics
bookstores, scattered in cities and towns throughout French-speaking
Europe.

5 For more details, see the interview with Serge Scotto "Ingrid de la jungle: un BD parodique," which aired on September 21, 2010: www.youtube.com/ watch? $=$ =NLa7loVGhHM.

6 In her memoir, Betancourt devotes several sections to describe how these pruebas were conducted by the FARC (see No hay silencio, 158-163: 242248: 657-664).

7 This appropriation of the Betancourt story fits well with the so-called FrancoBelgian comic book tradition, which, as McKinney argues, has long been entangled in history and politics, particularly with questions concerning colonialism, Nazism, and racism (he singles out, for instance, "the international flap" surrounding Tintin in the Congo in 1930-1931), despite the fact that "France makes considerable efforts to export its cultural products, including comics, to foreign countries" (16).

8 Gustavo Rueda Díaz, whose nom de guerre was Martín Caballero, led this FARC bloc for years. The bloc was responsible for the kidnapping of several US citizens. After Díaz's death in 2007 the bloc continued to operate in Bolivar and surrounding areas until 2016. The website www.resistenciacolombia.org/ now features the political party's platform created by former guerilla members after the signing of the Peace Accords. The main banner reads "Por una Colombia en paz con justicia social" [For a peaceful Colombia with social justice]. This site is devoted now to demobilization efforts in the Caribbean coast of Colombia and to gather some historical documents of the former FARC guerrilla bloc. The political party created by the FARC guerrillas in 2016 retains its acronym, FARC or Fuerza Alternativa Revolucionaria del Común; see (www.farc-ep.co/).

9 Mila Bongco in Reading Comics has argued that "superficiality has characterised much of the critical literature on comics longer than on most other popular forms," and this is due to what, for many, is a genre associated 
with "children" or the "sub-literate" (2). Certainly, the scenes in Ingrid de la jungle described above may appear "childish" but nonetheless underscore (albeit parodically) the transnational politics behind Betancourt's liberation efforts.

10 As Felipe Gómez Gutiérrez argues in "National Identity in Colombian Comics," there is a significant production of comic books (and graphic novels) in Colombia (perhaps not as robust as in Mexico, Argentina, or Brazil) that has gone mostly unnoticed by scholars. Comics such as Los perdidos and Virus Tropical address violence, displacement, and memory in ways that are complementary to established notions of Colombianidad.

11 There is a plethora of radio and TV interviews available online with Ingrid Betancourt after her liberation and during the book tour that followed the release of her captivity memoir. It is interesting to note the diversification of audiences and venues chosen for the Betancourt media tour. For instance, in the US, Betancourt chose to give interviews in a wide range of TV and radio forums (Oprah Winfrey, Larry King, Diane Rhem, Charlie Rose, or the PBS NewsHour, to name a few), thus reaching (shall we say) low, middle, and high-brow audiences.

12 Released by major international publishers in French (Gallimard), English (Penguin), and Spanish (Aguilar/Santillana) on September 21, 2010, Betancourt's memoir was the "book event" of the fall 2010 season, and soon after its release it became the most reviewed non-fiction book of the year and a top best seller, reaching the sixth spot on The New York Times list in early October 2010 and remaining in the top 20 throughout that month. Obviously, the data is only for the English version, but certainly we could find similar statistics for the French and Spanish editions; see www.nytimes.com/ best-sellers-books/2010-10-10/hardcover-nonfiction/list.html. It is important to note that the book's title comes from the poem "Para todos" by Pablo Neruda and is credited in the "Nota al lector."

13 The Betancourt memoir has no subtitle in Spanish or French. In the "Note to the Reader" at the end of No hay silencio, Betancourt explains why she chose to write her memoir in French: "French gave the necessary distance, and therefore, the control to be able to communicate what I was feeling and what I had lived through" (709; my translation)]. For a comparative overview of these three captivity memoirs, see Joshua Hammer's "Inside the Trap" in the New York Review (2010). Betancourt's No hay silencio is undoubtedly the crown jewel among the narratives of captivity in the Colombian jungle under FARC control.

14 The lack of chronological order in Betancourt's narrative is manifest throughout the entire chapter sequence of the book. For example, chapter 1 begins with her escape attempt (undated); chapter 2 takes place in February 2009 and January 2002; chapter 3 in February 2003; chapter 7 in April 2003; chapter 8 in March 2002; chapter 25 in September 2003; chapter 29 in October 2003; chapter 37 in March 2004; chapter 43 in August 2004; chapter 60 in January 2005; chapter 68 in May 2006; and chapter 70 in April 2007.

15 See also Cartas a mamá desde el infierno: "porque aquí, en esta selva, la única respuesta a todo es 'No'" [because here in this jungle the only answer to everything is "No"] (23); "la vida aquí no es vida, es un desperdicio lúgubre de tiempo" [life here is not life; it is a dreary waste of time] (24). 
16 In the case of Rojas and Gonsalves, the mediation of ghost writers (Isabel García-Zara and Gary Brozen, respectively) further complicates the determination of authorial voice in the text as these ghost writers do not act as advocates for the hostages' cause, but rather they supplant their "I" narrator.

17 In this connection, the remarks made by the series director, Silvia Quer, about the filming conditions reinforce the claim of authenticity: "[they] were hard, but we knew that you could go to the hotel, take a shower, and sleep in a bed [...] and to think that the real hostages don't have that escape route, that bed" (www.rtve.es/television/20110801/silvia-quer-era-gran-aventura-profesionalpersonal-no-dude-aceptar/451500.shtml).

18 Torres's book was marketed as the "true story" of Operación Jaque. He is a former collaborator of President Andrés Pastrana and held a post at the Embassy of Colombia in Washington, DC. While he was not a spokesperson for the Colombian government at the time of the FARC hostages release, his past political affiliation signals an alliance with the official story behind the rescue operation. Torres is also the Spanish translator of Gonsalves's Out of Captivity, a memoir by one of Betancourt's fellow hostages in the jungle.

19 In her memoir, Betancourt recalls listening to messages from her children through the radio program Las voces del secuestro [voices of the kidnapped] (www.lasvocesdelsecuestro.com). This radio show aired weekly and became the only way for most hostages to hear from their families while captive in the jungle (No hay silencio 641). The program's director, Herbin Hoyos, who fled Colombia in 2009 under death threats by the FARC, survived kidnapping by the FARC, created and directed Las voces del secuestro. It began in 1994 and became a conduit for families to communicate with their loved ones being held by the guerrillas in the jungle. It broadcast messages and stories from family members of the kidnapped for almost 24 years. The media's importance is addressed in one of the letters Betancourt wrote to her children while in captivity and later published in Cartas a mamá desde el infierno [Letters to Mom from Hell]:

$\mathrm{Y}$ es que nosotros le debemos demasiado a los medios. Es por ellos que no nos hemos vuelto del todo locos en la sola soledad de la selva.

And we owe a lot to the media. Thanks to them we have not gone completely crazy in the lonely loneliness of the jungle.

In Cartas a mamá, Betancourt openly displays her affection toward the political establishment in France, Colombia, Venezuela, and the US, countries where the media followed with great interest her capture and, ultimately, her liberation. For Betancourt's political connections with the French elite, see also Thomet's Ingrid Betancourt.

20 There are lesser-known films about hostage taking and the FARC in Colombia such as Rafael Lara's La milagrosa (2008), the horror thriller El páramo (2011) by Jaime Osorio Márquez, and the documentary Gente de papel (2014) directed by Andrés Felipe Vásquez. These films, however, have not entered the same distribution circuit and achieved the same international reach as films and TV programs more closely related to the Betancourt story.

21 Crisanto, now a free man, was convicted to a 33-year prison sentence, of which he served four years until Colombia's Supreme Court revoked his conviction in 2013. In his memoir El hijo de la selva, Gómez claims his innocence 
and denies any involvement with the kidnapping of Emmanuel Rojas or the FARC: "Hoy escribo desde la cárcel La Picota de Bogotá mientras soporto una agobiante injusticia" [Today I write from La Picota Prison in Bogotá while I bear an overwhelming injustice] (1). To this day, Clara Rojas disputes Gómez's version of the events that led to the FARC's handover of Emmanuel.

22 I am quoting here from the English publisher's website when the book was launched in 2015: www.penguin.com/book/the-blue-line-by-ingridbetancourt/9781594206580. This site is no longer available.

23 The report credits the following researchers: Andrés Suárez, Fernando González SJ, Rodrigo Uprimny, Pilar Riaño, Patricia Linares, María Emma Wills, Jesús Abad Colorado, César Caballero, Iván Orozco, León Valencia, María Victoria Uribe, Paula Andrea Ila, Luis Carlos Sánchez, Teófilo Vásquez, Nubia Herrera, Absalón Machado, Pilar Gaitán, Jorge Restrepo, Tatiana Rincón, and Álvaro Camacho. Credit is also given to national and international institutions (e.g., EU, Spain, Canada, Switzerland, US) that contributed to the report's findings. A shorter version, about 100 pages in length, is also available for download from the Center's website-centrodememoriahistorica. gov.co-along with the extended 434-page report. Whether intentionally or not, the report bears the name of the Spanish organization ;Basta ya!, which has advocated for the rights of ETA (the Basque separatist terrorist group) victims in Spain since 1999.

24 For instance, the Spanish daily El País offered on July 24, 2013 a headline titled "The armed conflict in Colombia left 220,000 dead since 1958," then followed by some detailing of the work done by the National Center for Historical Memory and its estimate of 25,000 missing, which "goes beyond the crimes committed in the Southern Cone" by military dictatorships (Reyes). It is important here not to forget that the interest of newspapers such as $E l$ País in the processes of recovery of historical memory has a direct connection with what has happened in Spain after the "Pact of Silence" (read "historical amnesia") that marked the first decades of democratic transition following 40 years of the Franco dictatorship.

https://elpais.com/internacional/2013/07/24/actualidad/1374677621_ 928074.html.

25 In addition, there are two more sites for national memory in ColombiaMedellín's Casa Museo de la Memoria (www.museocasadelamemoria.gov.co/, and the construction of Museo Nacional de la Memoria in Bogotá, which is scheduled to open in 2022 (http://museodememoria.gov.co/). Among the sites for memorializing atrocities in Latin America that come to mind are ESMA (the former detention center turned museum) in Buenos Aires (www. museositioesma.gob.ar/), or Santiago's Museo de la Memoria in Santiago, Chile https://ww3.museodelamemoria.cl/sobre-el-museo/.

26 Richard Crownshaw in The Future of Memory rejects the "hypertrophy" of memory present in Huyssen's approach, and advocates instead for opening memory to the future: "The remembrance of the past must be accompanied by the remembrance of the future" (3).

27 Alejandro Castillejo proposes another lengthy listing of 15 modalities of memory in relation to violence in Colombia- "la memoria," "memoria histórica," "memoria colectiva," "memoria individual," "memoria social," "memoria cultural," "memoria oral," "las memorias en plural (en tanto artefacto: una referencia a un relato en donde por demás - nunca se evoca el 


\section{The Ingrid Betancourt Story}

contexto de enunciación o sus condiciones de enunciabilidad y las agendas globales y locales con las que se interconectan)," "memoria traumática," "historia y/o memoria," el "archivo" (memoria de la nación), "los documentos" (que constituyen el "archivo" y que a la vez fundamentan la "memoria de la nación"), "construcción de la memoria," "reconstrucción de la memoria," "recuperación de la memoria" (contra "el olvido" o como una forma de "resistencia"), "verdad" (como soporte o como condición de "la memoria" y del "archivo"). While these modalities overlap quite significantly and Castillejo himself argues that they should not be taken as fixed categories, they do illustrate the difficult task of reconstructing the national historical memory ("Iluminan” 21-22). For her part, María Ospina's "memory puzzle" ("el rompecabezas de la memoria") looks at the intricate relationship between private memory ("memoria privada," read individual memory) and cultural memory, as the former-in the case of Colombia-is always mediated by the conflict and is therefore often subsumed in the latter (17).

28 For access to the Centro's publications and resources, see http:// centrodememoriahistorica.gov.co/. 


\section{The Travelogue Boom \\ Dark Exoticism for Global Consumption}

In recent years, travel books about Colombia have emerged as an important cultural product that caters to international audiences. As more travelers - mostly journalists and NGO advocates on assignment in Colombia-penetrate into the country's urban and rural areas, a plethora of travel narratives that bear witness to the recent changes in Colombia's tarnished international image has begun to appear on the cultural marketplace. Many of these narratives about the "new Colombia" are written for a new brand of international tourists or visitors who now venture into Colombia thanks in part to more positive media accounts; for example, those who have reported peace talks between the guerrilla and the government, and the overall improvement on security. "Benefiting" from the Mexican Drug War, Colombia is being steadily released from its former status as the focal point of Latin American crime and violence. The most recent travel narratives about Colombia reflect on this change. Travelers now visit the country, once universally perceived as a crime-ridden nation, to report on its beautiful landscapes amidst the remnants of violent conflict. As I will explain in this chapter, magical (exotic) and dark (gritty) portrayals of Colombia abound in these recent travel narratives. But these two poles of (what is seen as) the new Colombian reality now appear constantly in tension and provide for the cultural market another set of examples of the Colombian condition-one which permeates most of the reports (and other cultural products) emerging from Colombia.

This chapter focuses on travel writing in and about Colombia as a genre that is ideally suited for the market operations that continue to exploit the ills of this nation for global consumption. The narratives that I analyze here were written in the 1990s and 2000s by international travelers coming from the US, the UK, Canada, France, and Australia. They propose how the foreign "I/eye" reports from the Colombian front-the obvious implication being that this nation is still at war (with itself). It is a kind of reporting that also informs the writers' away-fromhome condition; that is to say, their travel narratives are as much about the Colombian guerrillas and paramilitary warfare or drug trafficking activities as they are about the travelers' own homes, the reference in 
relation to which their narratives are clearly established and positioned. These travel accounts foreground the self-reflection and the introspection in which the travelers engage in what they often describe as a far-away, magical, dangerous, and mysterious land. As is characteristic of the travel writing genre as a whole, Colombian travelogues underscore a subject positionality established from the top down as outsiders from the first world narrate their (ad)ventures into new and unexplored third world territories. ${ }^{1}$

In these narratives, Colombia is often described as a land of the magical and the gritty, of unexpected beauty and cruelty, of peaceful environs in a war setting. These juxtapositions can be found in a wide variety of travelogues dealing with personal memories and self-discovery such as Michael Jacobs's The Robber of Memories: A River Journey Through Colombia (2012), or Matthew Thompson's My Colombian Death: A Journey Into the Heart of South America's Most Dangerous Country (2008); or personal diaries of trips through the "land of danger" such as Glen Heggstad's Two Wheels Through Terror: Diary of a South American Motorcycle Odyssey (2004), Garry Leech's Beyond Bogotá: Diary of a Drug War Journalist in Colombia (2009), and Tom Feiling's Short Walks from Bogotá: Journeys in the New Colombia (2012); train journeys that capture the national past and present such as Ramón Chao's The Train of Ice and Fire: Mano Negra in Colombia (1994) or Stephen Smith's Cocaine Train: Tracing My Bloodline Through Colombia (1999). ${ }^{2}$

The advent of these new first world travel writers to Colombia (or Latin America) is not something new. For centuries, Latin America has been subjected to imperial eyes, as European travelers have descended upon the continent to report on the wonders and prospective exploits of this vast land. As Mary Louise Pratt has explained, the travel books that first told us about Latin America "gave European reading publics a sense of ownership, entitlement and familiarity with respect to distant parts of the world that were being explored, invaded, invested in, and colonized" (3). Not much seems to have changed in the new narratives about Colombia written since the 1990s. These narratives also conform to the kinds of colonial writing that was inspired (and, in some cases, mandated) by imperial power. Recent Colombian travelogues are replete with detailed descriptions of vast landscapes, and express fascination with great distances, multi-ethnic territories, and, of course, violence and the remnants it leaves in its wake. Unlike the "naïve travelers" of the 19th century, who sought to record and report back home about new lands from a rather ethnographic and anthropological angle, the writers of the new Colombian travel books seem to rely on their readers' preexisting familiarity with their subject matter. They seek to provide international readers with confirmation of what is already known or believed to be known: that Colombia is a land ruled by conflict, corruption, drug trafficking, and violence. Likewise, these writers' own a priori exposure 
to cultural representations of Colombia (and, by extension, of Latin America) serves as the point of departure for their stories.

Edward Said's Orientalism can be seen as the catalyst for a wave of studies that looked at ways in which travel writing, particularly of the 1990s, represented our cultures. It is important to reference Said because he points to the fact that travelers, before they travel, have already been influenced by the previous cultural representations they have encountered: "Thus, they never took on places anew or completely independent but perceived them instead through an accretion of others' accounts" (Youngs 9). This is crucial in the case of Colombia, where drug lords' (Pablo Escobar), guerrillas' (FARC), and paramilitaries' (AUC) violent acts have defined this nation's image for a long time. This "a priori exposure" to cultural representations will be crucial, as we shall see, for the analysis of Colombian travelogues.

Such travelogues are often constructed as exemplary validation of national crises, conflicts, and forms of violence. Why is it that these writers seek to replicate in their travelogues what the global media has already told us and continues to tell us about Colombia? What makes international audiences interested in the kind of dark exoticism that these travel books offer us? And, more importantly, why is there a global market for these travelogues of war? And how does that market itself contribute to the Colombian condition? These are some of the questions I will address in this chapter as I map out the importance of war, conflict, disaster, and other media-infused Colombian crises as they are presented for global cultural consumption in contemporary travel writing.

For one thing, it is my contention that travel writing is an ideally suited conduit for reporting on the Colombian conflict-i.e., for producing dispatches from the front that reinforce such conflict as essentially structured as a form of warfare. At a time when international audiences consume war and conflict via global media outlets, travel writing is articulated as a process of discovery in which authors themselves engage in a constant tug-of-war between self and other, between observer and observed, and often, in the case of Latin America, between dominant and dominated cultures. For Tim Youngs, travel writing is a hybrid genre that is difficult to demarcate:

It throws light on how we define ourselves and on how we identify others. Its construction of our sense of "me" and "you," "us" or "them" operates on individual and national levels and in the realms of psychology, society and economics.

A crucial element is that all travel writing presupposes the author's "visitor" status. He or she remains as the reader's surrogate, a cultural outsider who comes into, through and finally beyond the places and events encountered (7). 
From the reader's perspective, I take Casey Blanton's Travel Writing, the Self, and the World (2002) as a point of departure for my discussion on contemporary travel writing. She argues that

travel narrative is a compelling and seductive form of storytelling. Its reader is swept along on the surface of the text by pure forward motion of the journey while being initiated into strange and often dangerous new territory (...) the experiences in the outer world can be "transferred" to the self that is being scrutinized, thus converting the journey into a mode of introspection.

$(\text { Blanton 2-3) })^{3}$

It is precisely this type of introspection that dominates recent Colombian travel writing, which Blanton would situate within the context of selfreflexivity and instability that is common in late 20th-century travelogues. In these more recent accounts, "there is an impossibility of gathering self and world," that is, writers, through self-reflexivity and instability, lapse into a sort of inner struggle, and appear as a consequence to be less forceful in asserting their own presence among the "others" who are being observed (Blanton 26-29). Often, in Colombian travelogues we see the narrators dumbfounded by (internal) subject displacement and (external) war conflict, and by the narrator's consequent inability to wholly account for the national struggles that define Colombia as the land of "wandering subjects."

Influenced by the work of Homi Bhabha and his conceptualization of the "un-homed" (arguably a distinct feature of the global subject), Patrick Holland and Graham Huggan have pointed out that all travel narratives articulate or share "a poetics of the wandering subject." Such narratives "are less concerned with recuperating, or reinventing, a single self than with following the trajectory of a series of selves in transit" (14). In this regard, the Colombian travelogues problematize Bhabha's (somewhat) celebratory experience of the global subject in transit, which he describes in enthusiastic terms: "In the world in which I travel, I am endlessly recreating myself" (8). Moreover, for Bhabha, "to be unhomed is not to be homeless, nor can the unhomely be easily accommodated in that familiar division of social life into private and public spheres" (9). ${ }^{4}$ Such statements clash with the on-the-ground reality in Colombia, with its high volume of internal displacements throughout the country-displacements that have in effect produced many trajectories of transit in which these outside travelers/narrators also engage when they write their travelogues. In this way, Colombian travelogues are by nature doubly transitory, as both their narrating and their narrated subjects are selves in (constant) transit. In other words, such travelogues, while retaining the imperial "I/ eye" of colonial times, are simultaneously more concerned with shifting positionality of the "I/eye," as it becomes resituated within the transitory trajectories typical of the Colombian conflict: "The 'imperial I/eye' of the 
travel writer, in Mary Louise Pratt's conflation, is still operational in an age that, after empire, has yet to settle imperialism's scores" (Holland and Huggan 15).

But my primary focus here is not so much to further analyze the relationship between self and other (and the world) as the crux of travelogues. Rather, I seek to explore the specificity of that relationship within the cultural market conditions that have favored the explosion of Colombian travelogues for global audiences. This approach leads me to examine the production and distribution of Colombian travelogues within the parameters of "dark tourism"- a concept that has gained some traction in recent scholarship. ${ }^{5}$ Understood as "both a product of the circumstances of the late modern world and a significant influence upon these circumstances" (Lennon and Foley 4), dark tourism is, above all, a profitable industry. ${ }^{6}$ It draws worldwide visitors to "educational" sites of death and remembrance, war memorials, battle sites, graves of famous people, atrocities, and the like. All of these are within the parameters of the neoliberal economy and global communication that support and encourage practices of traveling to the "dark side." At the same time, such practices raise important ethical questions about the commodification of death for the purposes of the global travel industry. In the specific case of Colombia, "dark tourism" takes a somewhat different shape as there are no established memorials or places of "death worship" to visit (the exception perhaps being Pablo Escobar's grave or his self-made prison/headquarters, La Catedral). But the entire country can (arguably) be construed as a location for traveling to the dark side. I say "can" precisely because that is what many of the recent Colombian travelogues choose to do: traveling to Colombia and within Colombia is understood as inherently linked to practices of "dark tourism."

This desire to visit sights of death and disaster, as pointed by Sharpley and Stone, is not really new: "Indeed, for as long as people have been able to travel, they have been drawn-purposefully or otherwise-toward sites, attractions or events that are linked in one way or another with death, suffering violence, or disaster" (4). What seems to have changed in recent decades is the relevance of modern media and technology as responsible for "increasing the geographical specificity of murder and violent death" and for doing so with a greater degree of immediacy as we are led to witness these violent events as they unfold (16). This is important as a marketing device, as Colombia is marked with the plus sign of cultural difference, and becomes an "off limits" site attractive to the mass population that constitutes modern tourism's target. While not addressing the specific case of Colombia, Holland and Huggan situate the existing boom of travelogues in close relation to diversification in Western societies. As a consequence of concerns about increasing social homogeneity, there is a surge of "counter-travelers" in these societies: women, gays, eco-tourists, and the like are seeking an "oppositional stance to conventional modes of traveling" such as mass tourism. ${ }^{7}$ 
In this regard, Colombia (a multi-ethnic country if there ever was one) offers these new travelers the ultimate frontier for cultural diversification, "otherness," ongoing conflict, and unknown and dangerous territories. The country emerges as an ideal site for unconventional, diverse, alternative, or edgy travel. As Holland and Huggan point out, the new culture industry is cashing in on "Westerners' fears of homogenization" and "sanitized spectacles of mass tourism" (2), since

travel, at least potentially, opens up a world of estrangement, one in which the work-the travail-of travel is to engage with others productively, to produce a site or number of sites that resist uniformity, and that gesture instead to difference, "otherness" and diversity of (cross-) cultural forms.

It is not so much that we are all global now (whether we like it or not) but that, despite the fact that we are globalized, we see in exotic/dark narratives a conduit that moves us away from disappearing into homogeneity. Of course, a certain degree of homogenization is at the core of globalization. The more global we get, the higher the tendency to "equalize" and "brush off" differences. So alternative ways of traveling (such as those in/around Colombia) "provide an alibi for travel writing while still depending on its traditions and its—not least, commercial—cachet" (Holland and Huggan 198). Even these counter-traveler's narratives (for all their oppositional stances) "cannot escape being haunted by an array of hoary tropes and clichés (originary, primitivist, exotic, etc.), any more than they can hope to distill 'authentic' encounters from their commodified sources" (Holland and Huggan 199).

The Colombian travelogues that I analyze in this chapter present precisely this tension between old (colonial/imperial) and new (nonhomogeneous) tropes of travel writing within the global market's parameters of distribution and production. While these counter-travelers in Colombia cannot fully escape their preconceived ideas and cultural anchorage, there is (at least in their mind) a desire to reproduce in their travelogues these "authentic encounters." Nevertheless, Debbie Lisle's The Global Politics of Contemporary Travel Writing (2006) insists that the historical traits of Empire are still present in contemporary travel writing, despite the efforts of new contemporary travelers to abandon the exploitative colonial heritage (2). The legacy of Empire remains even as it is becoming impossible to consider travel writing outside of the realm of post-colonialism: "Contemporary travel writing continues in the Colonial tradition: it reproduces a dominant Western civilization from which travel writers emerge to dominate other states, cultures, and people" (3). This often results in "passing judgment on less-civilised areas of the world," and enacting a certain superiority of the travelers' cultural and moral values (3). For Lisle, then, there still remains an implicit tension between colonial and metropolitan visions in contemporary travel 
writing. Although many of the so-called counter-travelers (e.g., those coming to report on Colombia) seek to bring a cosmopolitan vision to their travelogues, they are nevertheless still subjected to the "simple logics of dominance and subordination" that have defined the imperial "I/eye" for centuries and now continue to do so in the global era (even under allinclusive conceptualizations such as the "global village"): travel writers "currently articulating cosmopolitan visions of the world do not avoid the 'embarrassing' attitudes of their colonial predecessors-they actually produce new forms of power that mimic the previous sensibility of empire" (5). As new travelogues shift toward cosmopolitan, global, and diverse forms of travel writing, Lisle then sees a certain degree of depoliticization in their narratives, despite their celebration of "equality, tolerance, and cultural diversity" (15) — the result being that contemporary travelogues are ultimately depoliticizing: "they cover over the inherited power relations of Empire by telling supposedly neutral and objective stories about encounters with difference" (265). Despite globalization's efforts to level off cultural differences, "travel writing remains popular because it feeds images of otherness utilised by colonial writers and, as such, provides sanctuary from 'politically correct' attitudes about race, gender, sexuality and class" (19).

It is, then, no surprise that Colombian travelogues are used as exemplary cases for "encounters with difference": what could be more different than a multi-ethnic country with four distinct war apparatuses (drug traffickers, guerillas, paramilitaries, and the national army), all financed (wholly, partially, or through payoffs) by the commerce of illicit drugs? What is fairly clear is that Colombian travelogues are anything but depoliticized, since in them there is a level of advocacy and "global duty" on the part of these new travelers who, despite preconceived imperial positions in their writing, seek to expose the past and present condition of the nation's social conflict. Granted that these Colombian travelogues persist in colonial portrayals of otherness and difference as illustrated by their abundant descriptions of threatening and magical landscapes. But not all travel writing that adheres to these established topoi can be simply ignored as a conservative genre that reinforces imperialism: "Travel writing is-fittingly - a dynamic genre, often employed for radical aims. It is associated with colonialism and capitalist expansion and with patriarchy, but can be also oppositional, interrogative and subversive" (Lisle 14). The Colombian travelogues that I analyze next show precisely these tensions between imperial and oppositional voices that are necessarily associated with anyone who is on assignment in Colombia for the purpose of global advocacy.

\section{Writing Through the Lost Tracks: Ramón Chao's and Stephen Smith's Magical Mystery Tours}

Colombia's now defunct passenger railway system is the starting point for two travelogues that demonstrate the cultural commodification of this 
nation's past and present challenges for global audiences: Ramón Chao's The Train of Ice and Fire: Mano Negra in Colombia (1994) and Stephen Smith's Cocaine Train: Tracing My Bloodline Through Colombia (1999). These are exemplary narratives of the "report from the front" type that are characteristic of the foreign "I/eye" watching over global inequalities, conflict, and social transformation. Written about five years apart, both travelogues are constructed as personal narratives of discovery propelled by Colombia's loss of a viable train system. Chao's and Smith's narratives span a fairly large period of the nation's modern history as both aim at reconstructing this nation's past by looking closely at the abandoned train tracks that once served the country as a vital form of transportation and economic development. In Chao's case, the travel narrative is organized through spotty diary entries narrating the "tour of peace"/"tour of goodwill" that the French pop/rock band Mano Negra conducted in Colombia in 1993. Smith's narrative, for its part, reconstructs a dark family secret tied to the Colombian national railway system and the UK engineer Leslie Frost (the author's maternal grandfather) who designed many of its tracks during the 1930s and 1940s. In both travelogues, the writers engage in a reconstructive historical (and magical) tour of Colombia by tracing the steps of this nation's armed conflict, an operation that also enables them to learn about their own personal anxieties as travelers in an unstable political and social climate.

Written by the journalist Ramón Chao, the father of Mano Negra's band leader, The Train of Ice and Fire first appeared in French in 1994, published by a small independent press, and remained for the most part unavailable to international audiences. But in 2009 the book was translated and published in English, and soon became available in digital format, which made it more widely accessible for international audiences. The Spanish version, translated by Santiago Gamboa soon after the French release, was published in Madrid in 1994. To this day, there is no Colombian edition of The Train of Ice and Fire despite the fact that Mano Negra's train journey was widely reported in the Colombian press, which followed the band in the (mostly rural) locations chosen for the series of concerts that constituted their "tour of peace." ${ }^{8}$ Mano Negra's tour was conceived to reach out to small rural communities that had endured guerrilla and paramilitary warfare. As the band embarked on a journey that was (at least, from the logistical viewpoint) almost impossible using the existing train tracks connecting Bogotá and the Atlantic coast, Chao was there to report on it. The trip had all the makings of yet another great story of survival, adventure, displacement, and violence to be enjoyed by the cultural global market. And The Train of Ice and Fire is consequently an exemplary account of the Colombian condition, under which cultural products originating in Colombia are irremediably linked to manifestations of violence and displacement, even in cases where there is no intention to promote such manifestations. 
The train journey, originally planned to reach the resort town of Santa Marta (roughly 1,000 kilometers from Bogotá), was to provide a series of ten concerts and circus-like shows and performances at abandoned train stations and depots along the way. Among the attractions brought by the train (beyond the music concerts) were the fire-spouting wagon and the one that fabricated ice; the "cage-wagon"- described as "an enormous iguana metamorphosed into a dragon"-; the "fairground wagon," home of "the magical and the daring;" and the "crane-wagon" set up for "the trapeze and tightrope acts" (Chao 15-16). This set of attractions were purposely modeled after colorful carnival shows typical of itinerant circuses and gipsy tribes. With that in mind, Mano Negra embarked on its planned itinerary on November 15, 1993, with a view to entertaining and bringing solace to communities immersed in violence.

Coincidentally, however, the tour began at a crucial moment in Colombia's most recent violent history, just a few weeks before Pablo Escobar was gunned down on the rooftops of Medellín and right in the middle of an upheaval of guerrilla and paramilitary activity. Not unaware of these developments, the band decided to incorporate as one of its train attractions the so-called "Office of Human Desires," an impromptu message board that provided concert goers with a channel to express their thoughts about events on the ground. The travelogue reproduces (at least partially) the messages written in Santa Marta $(63,74)$, Aracataca (94), Bosconia (107), Gamarra $(118,128)$, Barrancabermeja $(144,148)$, La Dorada (165), and Facatativá (190). Chao intercalates these messages in his travelogue in no apparent chronological sequence in an effort to present the "real voices" of Colombia expressing their desires for the nation. So it is significant that, throughout most of the narrative, there is very little direct voice given to the Colombians that Mano Negra encountered along the way, Chao's travelogue being mostly narratorcentered, and foregrounding as a consequence the viewpoint of the observer rather than that of the observed. Most of the messages posted at the Office of Human Desires ask for the cessation of violence, and openly criticize politicians and the government for its delay. They also point out the significance of the band's incursion into areas of armed conflict, stressing the validity of the band's "tour of duty" and the desire of the message-posters for the train system to be revived in Colombia. In this regard, a 14-year old named Cristiano Buenahora seems to buy into the band tour's premise as he writes "I want the railway to work well so it will bring peace to Colombia" (128); likewise, Fidelina Rojas, a 32-year-old resident of La Dorada, reflects on the effects of the train tour: "I dream of travelling and seeing countries, because you foreigners have left a very beautiful souvenir in our Colombia" (165). The messages offer us an unmediated glimpse into the desires and fears of Colombians. Chao provides no context for the reproduction of these messages, as they stand alone in separate sections that are intercalated with his travelogue entries. 
These message-board quotations are there to underscore the goal Mano Negra had in mind when they decided to engage in such an apparently daring undertaking: "to reactivate a form of transport that is so crucial to a country's social and geographic fabric" (7). But, more importantly, Chao's travelogue presents both the inside and the outside views of the Colombian conflict as they are reported by the band members themselves, the concerts' attendees, and, of course, the narrator's own reflections along the journey. These two sets of views-those of the observed and those of the observer-are symptomatic of travel writing and of the encounter of "two worlds" (Europe and the Americas) proposed by the incursion of Mano Negra in Colombia, which, as I pointed out in the introduction to this chapter, are often enacted in Latin American travel writing. ${ }^{9}$ Nevertheless, the narrative also goes well beyond the band's tour with a view to exploring the national crisis in Colombia resulting from the demise of the railway system. This is an important historical moment, involving the realignment of social and economic forces in the country, and one that Mano Negra wishes to capture as part of their tour of duty.

To this end, Chao (and the band members) turned to Gabriel García Márquez, whose writings have reflected on the advent and demise of passenger trains in Colombia and absorbed this history to (re)create his brand of "magical realism." 10 Chao's book title evokes, of course, the opening line of Gabriel García Márquez's Cien años de soledad, a phrase that sets the tone for Chao and for the entire Mano Negra tour: "Many years later, as he faced the firing squad, Colonel Aureliano Buendía was to remember that distant afternoon in which his father took him to discover ice" (1; also quoted in Chao 27). Chao uses the type of spiral temporality present in this opening sentence in order to intersperse his own train narrative with a back-and-forth temporality that juxtaposes current and past events of Colombian history with Mano Negra's goodwill tour. As in Cien años de soledad, Colombia here remains a country under fire-that is, immersed in guerrilla, paramilitary, and narcotics warfare (the parallel being the War of a Thousand Days in the novel)—but simultaneously subject to magical incursions like the sudden appearance of ice, which the circus-like performers and the band Mano Negra provide for onlookers in rural settings along the train's path. In this regard, the entire train trip can be read as an attempt to bring ice to the fire, that is, to bring the band's "magical mystery tour" and its extravagant performers as forms of appeasement to hot spots of the armed conflict. This is reaffirmed in the words of Coco, one of the architects of the band's Colombian tour, who explains that "to make people talk about something other than terror in Colombia, I conjured up this idea with a show reconciling the two hereditary enemies, fire and ice" (24).

So, García Márquez's magical realist vision of Colombia remains in play throughout the entire travelogue, as Cien años de soledad is constantly referenced and referred to by Chao and the members of the 
band. ${ }^{11}$ Such references can be found also in the photo album included in the English edition that documents the band's sideshow recreating the discovery of ice in Colombian rural communities-a clear evocation of Melquíades's inventions in the novel. But, more importantly even than the ice discovery episode (which would rather fall within the realm of the marvelous real), Chao seeks to revisit two key moments from García Márquez's novel with a view to giving his international readers some historical context about events in his travelogue. By means of these frequent references, Chao seeks to re-familiarize his readership with García Márquez's text and to situate his own travelogue in the works of the Colombian maestro.

One such moment is Chao's dream prior to the train's departure from Bogotá. It echoes (at least in its form) José Arcadio Buendía's foundational dream of Macondo, which Chao will later reference in the travelogue (86):

my dreams were populated by guerrillas, bandits, soldiers, paramilitaries, drug traffickers; that charming mix that makes Colombia the world's most violent country [...] In my nightmares, all sorts of disasters befall us: bombs exploding on the track, attacks by armed gangs, gun battles, knives stuck in hearts.

Chao's premonitory dream illustrates the preconceived ideas about Colombia that he himself (and arguably Mano Negra) held prior to the band's Colombian tour. It likewise brings to the fore the fact that premonitions in Colombia tend to become true (as in the case of José Arcadio Buendía), and indeed certain dream events do in the end materialize in this land of the magical. Another instance is the famous (and historically grounded) banana massacre of the 1920s, when Colombian workers of the United Fruit Company clashed with the army in a bloody battle. Central as it is to García Márquez's novel, this episode recreates a nightmarish experience for the family patriarch's son José Arcadio II. In Chao's account it also underlies the deterioration of the band's trip as the performers reach the area in which the massacre took place, now still pervaded with the memory of violence:

The concert at Ciénaga has been cancelled. Ciénaga is a small town some fifty kilometers from Santa Marta, scene of the terrible banana massacres in 1928. Not much has changed. The authorities want to give us an army escort during the trip, our stay, and the concerts.

As we can see from these two examples, the fiction of García Márquez is for Chao not only a valid source of cultural information but also a necessary key to understanding the historical milestones of Colombia's violent 
past. Chao uses García Márquez's narrative as an exemplary model of the magical aura that informs both these writers' visions of contemporary Colombia. It is no surprise that, during the band's visit to Aracataca (García Márquez's hometown and the inspiration for Macondo), Chao mentions "the beauties descended from Úrsula and Coronel Aureliano Buendía" (82), the gypsies' visits, and the people who, to this day, claim to have known "a whole series of Aurelianos and José Arcadios" (83). In his effort to re-write or revisit the magical realist world of García Márquez's Cien años de soledad almost 30 years after its publication, Chao borrows almost verbatim García Márquez's initial description of Macondo and resituates it within present-day economic conditions:

Aracataca was founded here because of the quality of the soil and its privileged position vis-à-vis the sandbank. It's no longer the village of twenty mud and straw houses beside a diaphanous river running over a bed of polished stones as big as prehistoric eggs [...] The river is muddy, dirty, a far cry from its ancestor. The houses have kept the same structure [...] The primitive hamlet has metamorphosed into a bustling town, with shops, artisans' workshops, and a road with constant stream of traffic.

This incursion of the fictional Macondo into the real Aracata Chao is visiting with Mano Negra highlights the dual reality that the foreign "I/eye" seems inevitably to impose on Colombia. Linking the country's present to its primitive, mysterious, and intriguing past (albeit devoid of a fictional description), Chao conforms to both the former imperial/ colonial and the present-day cosmopolitan visions of travel writing. While Chao does not reproduce the novel's second sentence verbatim, he is obviously juxtaposing the primitive and contemporary views of Aracataca/Macondo:

At that time Macondo was a village of twenty adobe houses, built on the bank of a river of clear water that ran along a bed of polished stones, which were white and enormous, like prehistoric eggs. The world was so recent that many things lacked names, and in order to indicate them it was necessary to point.

(García Márquez, One Hundred Years of Solitude 1) ${ }^{12}$

In this way, The Train of Ice and Fire presents the complex reality of Colombia as corresponding both to the realm of the gritty present and to that of the magical past (e.g., "the muddy, dirty river" of Aracataca and the river of "clean water" and "polished stones" in Macondo). Ignacio Ramonet's prologue anticipates this perceived duality of the Colombian nation, which is now anchored in the minds of many international readers and which The Train of Ice and Fire duly exploits: 
[this book] envelops you in a world of smells and aromas, you see landscapes and faces, feel heat and cold [...] Terror has taken possession of these breathtakingly beautiful regions [...] these joyful people, whom the train of ice and fire met during its journey, are still dreaming.

Taking this as a cue, the incipit of Chao's travelogue anticipates the intrigue and mystery to be encountered in the pages ahead: "I went to Colombia because I was scared. My two sons were involved in a journey on an as yet non-existent train, on rusty tracks, through dodgy guerrilla country" (7). As someone who knows Latin America quite well, Chao shies away (in most instances) from the lengthy descriptions of Colombia's landscapes that would position him as the European voice marveling at the beauty of this new land. He is, instead, an informed traveler, but one who nonetheless cannot always distance himself from his preconceived ideas about the Colombia he is about to face, and perhaps wants to face. The rare descriptions of the country's beautiful landscapes seem timid (30; 100); and in the final pages of The Train of Ice and Fire it is the darker side of Colombia that is prominent. Just as the train journey has flopped along the way and several band members have deserted the tour, Chao's travelogue reflects on the current difficult state of play for most Colombians. He points out, for instance, that "the living conditions for the majority of the population of Bogotá are totally sub-human, worse even than other Latin American capital cities" (178). Moreover, the massive population displacement the country has experienced "has turned Bogotá into a city-refugee camp" in which "the overpopulation brings with it inequalities, accentuates social segregation" (215). In the end, fire does trump ice in Chao's travelogue as in Mano Negra's attempt to restore the railway system and, ultimately, to bring back peace.

The travelogue Cocaine Train: Tracing My Bloodline Through Colombia has a different premise than Chao's, but it too seeks to reclaim the importance of a viable railway system for Colombia. Its author, the British journalist Stephen Smith, travels to Colombia not as part of a collective tour of goodwill, but rather as a matter of personal duty to search for a lost link in his family bloodline. The family story regarding Colombia began in the 1930s and 1940s, when his grandfather (Leslie Frost), while working as an engineer for the Colombian railway system, had an extra-marital affair with a housemaid (Beatriz Forero). Many years later, after the engineer's death, Smith decides to embark on a Colombian adventure to locate his great uncle, the son of Leslie Frost and his Colombian mistress. With no name at hand and very little information about how to locate his lost great uncle, Smith traces documents housed at the railway company's archives, interviews people who were familiar with the glory days of train travel and its demise in Colombia, and travels along some of the train routes his grandfather helped build in 


\section{The Travelogue Boom}

an effort to find clues leading to his Colombian family. Smith's journey is, indeed, one of personal discovery, of family secrets and lost lineage. But, above all, it is a typical Colombian travel narrative of self-examination amidst (what a foreign journalist perceives to be) a hostile environment in a dark, dangerous, and violent country.

As an exemplary Colombian travelogue, Smith's narrative was clearly marketed as a travel book for those global readers interested in experiencing both the darker and the more magical sides of Colombia. The book was published in the UK by Abacus (an imprint of Little, Brown and Company), which promoted it as an unwise and daring personal journey to a "surreally beautiful, unfathomably savage, [and] seedily glamorous land" where the "cause of death is regularly "massacre" (back cover). The print edition of 1999 became available in digital format in September 2012, coinciding with the publication boom of Colombian travelogues. Cocaine Train is mostly unknown in Colombia since no Spanish translation is available for this book, and only one library in Bogotá, the Biblioteca Luis Ángel Arango, currently holds a copy. This limited availability reinforces the idea that Smith's travelogue is written for global audiences (i.e., international Anglophone readers) seeking to immerse themselves in exploring the tarnished image of Colombia. ${ }^{13}$

To set the tone for the travelogue and for his personal adventure in Colombia, Smith opens his narrative with the image of a train slowly moving into darkness: "The train crept into darkness as though it was dragging its feet, as though it was as reluctant as I was myself" (1). This opening sentence serves as a marker for things to come. Throughout the book, Smith's recurring dark views of Colombia as a nation lacking in viable political or social structures and on the edge of collapse will appear in tandem with his personal thoughts on the abandoned tracks, his family, and his lineage. ${ }^{14}$ It is no coincidence that the phrase "the train crept into the darkness" appears four times $(1 ; 5 ; 7 ; 8)$ in the opening chapter, which presents the somewhat distressing panoramic view of Colombia that Smith embraces without nuance: "I had been right all along. Colombia was as bad as I'd been told, as bad as I'd thought, and this was it" (5). But this vision of darkness also extends into Smith's own personal life, so that the trip to Colombia is also about reclaiming something personal from the overall darkness, something deriving from Leslie Frost's legacy: "The following account is about darkness, a darkness which has overwhelmed an entire country, another which has fallen across a single life" (6). Darkness, therefore, envelops all things in Smith's Colombian travelogue: it is about Colombia but as well about a dark family secret, the illicit life (or double life) of a well-respected engineer. With the advent of the outside observer, who traces the origins of this double darkness through the abandoned train tracks and the defunct passenger railway system-once a sign of prosperity and economic investment for the country-, the task is to recover the lost train tracks as a means to uncovering the family history that was left behind. ${ }^{15}$ 
To navigate such enveloping darkness, which is part and parcel of Colombia in Smith's view, the traveler must also come to terms with this nation's "shocking" and "intoxicating" aspects. For Smith, "Colombia is shocking" (he actually repeats this phrase several times in the opening chapter) in that it is a place where "the most outrageous thing that can happen [...] has already happened" (10)—a key phrase in view of the family history he seeks to uncover. It is a nation of extremes (e.g., drug trafficking and guerrilla warfare against the backdrop of beautiful landscapes) but one that ultimately wins you over, even when there is a dark family history embedded in it.

A case in point can be found in the travelogue's section about the train line from Cali to the port city of Buenaventura, a preferred train route used by cocaine smugglers riding through the landscapes of the Valle del Cauca. This is the titular "Cocaine Train" (74). Smith has a chance to ride it with no other passengers on board, and no narcos in sight. Given that the national train network system was suspended in 1992 and Smith's travelogue appeared in 1999, it is safe to assume that some special arrangement was made for Smith to experience the abandoned train line, possibly thanks to his familial connection with Leslie Frost, possibly because of his being a foreign journalist seeking to revitalize the train system. As Smith travels toward Buenaventura- "the fondly remembered run to the sea of the Swiss" (79)—, thinking about Frost's engineering career and the train's demise, Colombia begins to win him over: "Colombia was acting like a narcotic on me" (79).

Indeed, this narcotic effect seems to increase as Smith gets to know more about the railway systems and comes closer to meeting his lost great uncle: "it was the effect of Colombia: in that drug-addled country, the strongest intoxicant was turning out to be the country herself" (105). Smith's intoxication fits well with his idea of Colombia as an incongruous land of beauty, wrongs, and unexpected wonders and surprises. It is not quite the familial memory of Colombia that his mother construed for him as a child, "a magical place of sun and mountains and animals" (228). Aware as he is of the upsurge of violence in recent decades, Smith wonders if his lost uncle may be a "narco-baron" or perhaps a corrupt politician. But when he finally meets his great uncle, Federico Forero, in the town of Mariquita, all his initial fears are quickly dispelled: "everything you could want in a long-lost uncle, all the same: handsome, assured, a figure of integrity" (210). In this encounter, Smith will learn that his grandfather had a second son with Beatriz, a fact that he refuses to reveal to his mother back in the UK. The fact that no information is given about this second son (perhaps he became a narco or a corrupt politician, as Smith had feared of Federico) continues the lost family lineage and perpetuates the mystery that surrounds it. In that respect, Smith's tendency to adhere to his preconceived ideas about Colombia is reinforced in the family episode so that ultimately the Forero family (that is, the illegitimate branch of the Frost family) remain portrayed as "other" and not his own. It is part of Colombia's "shocking" and "narcotic" character. 
But it would be unfair to characterize Smith's travelogue as a simple one-sided, top-down reading of Colombia linked to the predominantly imperial mode of travel writing about Latin America. True, he is a British subject reporting on the failed infrastructure built by his grandfather under the postcolonial regime of expanding coffee trade. But Smith's (often romantic) reconstruction of the train journey is inevitably linked to the reconstruction of this family lineage and to his journey of personal discovery. In this regard, Smith's account, while emphasizing the darker side of Colombia, nevertheless reflects on the global media's wrongs and rights in its depiction of the country. For instance, Smith makes a point of not associating guns with drugs and drugs with guns. He points out, correctly, that guns were there well before the boom in drug trafficking began during the labor disputes in the oil producing area of Barrancabermeja (11), for instance, or the banana plantations strike of 1928-both of which had already produced significant levels of violence $(45-46) .{ }^{16}$

Smith aptly closes his travelogue with a chapter devoted to the only passenger train line currently running in Colombia, the tourist train from Bogotá to Zipaquirá, where the Salt Cathedral (an underground cathedral built in a salt mine) is located. This is also an opportunity for him to return to his initial theme of darkness as the defining characteristic of his travelogue. As he descends into the mine at Zipaquirá penetrating into the "guts of the earth," he sees Colombia as an "unholy country, going on in the darkness" (236). His final chapter sums up his own journey of discovery, then, as itself a trip into the darkness of the country and of his family. In the closing paragraphs, he reiterates the two modes of writing that have become synonymous with Colombia and, by extension, with Latin America:

Carretera del Norte didn't look much like the "road to death" but the Colombia you encountered every day, the Colombia of the mountains and rivers, parks and mules and soot-trailing busetas, of maudlin vallenato and maize cakes, was an incongruously beautiful backdrop for guerrillas and death squads and drug gangsters.

As the travelogue closes, Smith reinforces the idea that beauty in Colombia is often "interrupted" by the harsh realities of everyday pollution, noise, and violence. This understanding has informed his itinerary through Colombia:

My mind had been full of death, the death that seemed synonymous with Colombia in the 1990s, the long-ago death of my grandfather, the death of my father. I had found the Colombia I had been expecting, the Colombia I deserved perhaps. 
Like many other contemporary writers, Smith has confirmed the expectations and preconceived ideas that brought him there, rather than allowing himself to be surprised by the discovery of a new country or a place unforeseen.

\section{Writing Home from Colombia: Losing Memories and Sights with Matthew Thompson and Michael Jacobs}

Colombia-seen as the land of adventure, mystery, and terror-is the place chosen by Matthew Thompson and Michael Jacobs to be away from home. Their respective travelogues, My Colombian Death: A Journey Into the Heart of South America's Most Dangerous Country (2008) and The Robber of Memories: A River Journey Through Colombia (2012), situate Colombia as the perfect place where one can disconnect from daily realities and routines, a place one goes to in order to lose sight of things, to disappear, and ultimately to gain perspective about one's life back home. These travelogues appear to be about "forgetting home" but are, in fact, about "writing home," which is something inherent in any travel writing experience: the traveler always brings his/her own home to the foreign place he is visiting, through preconceived ideas and unavoidable comparisons between home and the foreign land. But in the cases of Thompson and Jacobs, being away from home is the actual trigger for their travel narratives, and Colombia is the location where one may be "fully disconnected" from one's homeland. As can be surmised from the titles of their respective books, Thompson's travel account favors and exploits the darker side of Colombia whereas Jacobs', inspired by a chance encounter with García Márquez, favors the realm of magical realism. Both travelogues, however, have their fair share of both magic and darkness to offer in their representation of the Colombian way of life.

Thompson's My Colombian Death tells an adventure of survival through a series of episodes that explicitly seek to bring out the darker side of Colombia. As announced on the book's back cover, Thompson's travelogue invites readers on a journey of terrors where "killing might be fun," "where life is cheap and so are the drugs," and "where the lines between friend and enemy, life and death, are often impossible to detect" (cover). ${ }^{17}$ With this setup in mind-one that obviously fits the market-niche that presents the Colombian condition in the context of global thrills for broad cultural consumption-, Thompson embarks on a suicidal journey that allows him to break off from home and family responsibilities. The allure of Colombia, for him, is two-fold. He wants to experience the country where he could have migrated with his parents at an early age (his mother refused, and the family moved to Australia instead), and, more importantly, he wants to end the monotony of his life in Sydney where he works as a reporter for the Sydney Morning Herald.

From the start, Thompson describes Colombia as a land of "perpetual civil war," "kidnapping free-for-all," "narco-terrorism," and "native 
shamans dispensing the world's most powerful hallucinogens" (5-7). The tipping point of his journey will be his near-death experience (or "bad trip") with the hallucinogenic plant yage, which is detailed in the last section of his travelogue. As his itinerary makes clear, Thompson wishes to encounter, and to defy, all possible dangers along the way. These include drug-infested shantytowns, and guerrilla and paramilitary leaders, circumstances that present opportunities for the most daring and reckless behavior that Colombia can afford him. It is a matter of personal liberation, of bringing about a complete disconnect from home and from his known environs. And as the travelogue takes us through the usual sites visited in Colombian travelogues (Bogotá, Medellín, Cartagena, and zones of paramilitary and guerrilla conflict), Thompson thrives on the idea of being "un-homed." Colombia, it seems, is the ideal location if one wishes to be the farthest possible removed from home, and transported into a completely different reality: "Get me to Colombia so I can disappear into an overwhelming present" (18).

This "overwhelming present" (which for Thompson is peppered with drugs, armed conflict, and terror) facilitates the utmost sense of liberation. As the trip develops, he becomes increasingly fearless, a kamikaze traveler who pursues a no-holds barred Colombian experience. It would almost seem that Thompson "gets a high" out of such encounters reinforcing as they do his quest for death in Colombia. A case in point is Thompson's reflection in advance of his meeting with Salvatore Mancuso, the head of the paramilitary group AUC (Autodefensas Unidas de Colombia) ${ }^{18}$ :

What a privilege it is to be a free-ranging shape-shifting visitor who can climb without harm through the splendours of terror in Colombia. Nothing can hurt me while I'm on a roll-not the drugs, the gangs, the bulls, the predators or the poverty [...] I am rootless, with nothing to defend but my freedom.

Similarly, when he ventures into FARC territory in the jungle, Thompson declares: "my senses are thriving in these badlands, my nerves flood me with joy [...] I am unstoppable, unafraid, impregnable” (220). Unafraid of the encounter with the other, Thompson always positions himself as superior. Throughout most of his travelogue, he places himself as the outside observer who usually has the upper hand when facing a dangerous encounter with the observed. It is as if his self-positioning as the intrepid and fearless traveler descending into "hell" is meant to defy conventions of political correctness and challenge his readers. Having said that, it would be unfair to say that he is ignorant or lacks historical or contextual understanding about the Colombian armed conflict; for instance, he demonstrates that he is fully aware of the demobilization efforts that sought to end paramilitary activity in Colombia (98-99; 190; 208-209). Yet he is always quick to offer his reader some ready-made judgment. We 
see this when, after relating his encounter with Mancuso-“Colombia's prince of darkness" - he concludes: "This is just a country of predators, of the puma, the jaguar, of lithe and silent beasts" (217).

Thompson's relationship with the "other" (as beastly, savage, etc.) is inherent in the postcolonial tradition of seeing Latin America (or Colombia, in this case) as a strangely beautiful land ridden with danger, terror, and filth. For the purpose of his travelogue (after all, it is a journey of death), he zeroes in on landscapes of grit-sometimes literallywherever he can find them. His depiction of Cartagena (86-97), far away from its beautiful colonial architecture, is informed by dilapidation and waste:

I cross boulevards of abandoned road works where grit is whipped by coastal winds and sewage bubbles to the surface, flowing over intersections and along gutters beside food stalls [...] The grit and buman waste in the air are attacking my lungs.

(90-93; my emphasis)

It is precisely this type of description that allows Thompson to feel distant from home (e.g., from comfort, order, tidiness), and closer therefore to his ultimate goal of becoming part of the human waste he anticipates in his "Colombian death." But even in instances where he is consciously seeking it this way to bring out the darker side of Colombia, the strangely beautiful land takes over his senses. Such is the case with his first impression of Medellín from the air:

the blackness of clouded mountain night below us dissolves into orange yellow pinpricks of light [...] the dotted runs of streetlamps and car lights way down below also curve steeply across the far side of a gulf in space, glittering from above like a city thrown in the air. I lose orientation; it is too beautiful and strange.

Strangeness and disorientation in relation to what most international audiences still perceive as Colombia's crime and drug capital are the markers for Thompson's “away-from-home feeling.” Despite (partially) sharing the media-created version of Medellín, Thompson remains sensitive to its beauty: "Medellín, where even the dove of peace has been bombed, but it is beautiful, all is forgiven. Clouds blot the stars and then release them again" (239).

As we see in Thompson's depictions of Medellín, Colombia has begun to win him over. There is an "intoxicating" feeling about being disoriented, rootless, "un-homed," and Medellín is the catalyst that brings this experience to consciousness. It is no coincidence that it is in this city where Thompson begins to search for a shaman who will initiate him into the rites of yagé consumption. ${ }^{19}$ The yagé experience (which broadly falls 
under the category of magical Colombia) leads Thompson to discontinue his adventure and return to his wife Renae and their child in Australia. So it is an important moment in the structure of his travelogue, not only in terms of moving toward the realm of the magical, but because it also marks an important shift in the writer's positionality. Early on in his travelogue, Thompson tells of an episode about the "magical qualities" of Colombia, which are central to the closing sections of My Colombian Death. Thompson meets an Australian musician who refuses to read García Márquez's Cien años de soledad: "I hate that whole fucking magic realism shit. It's too cute. This place is about as miraculous as drinking Drano" (169). But his initial reaction against magical realism changes quite significantly toward the travelogue's end. Once in the hands of the shaman, the outsider traveler becomes the subject of his own observation, thus having to relinquish his authoritative colonial/imperial stance and ultimately his sense of orientation, of home.

The yagé trip and its magical or curative qualities are foreshadowed in the opening chapters when Thompson visits the Museo del Oro in Bogotá. Examining Muisca artifacts and reading about shamanic rituals in ancient Colombia, he describes ayahuasca or yagé as a potion leading to trance: "it has purgatory properties which initially make imbibers violently sick but it also contains powerful psychoactive chemicals that induce visions, apparently favouring jungle and lost-civilisation themes" (61). It is important to note here that his description of yagé effects coincides with the travelogue's account of Colombia as a country that will both make you "violently sick" and "purge" you. This combination of violence and purgation has been all along the purpose of the trip, a near-death experience in a country of "intoxication" that "runs on getting wasted, on sickening levels of self-indulgence" (298). Up to this point, such modes of intoxication have also allowed Thompson to feel free and "away from home." But as yagé takes full effect on his body, producing vomit, a weak pulse, and a drowning sensation, Thompson begins to fear death, to fear being "a voyager without hope of return" (302):

The yagé is killing me [...] I am overdosing [...] I am dying in a Third World toilet. I threw everything away. I put Renae through hell and stole her baby's father away to go die from drugs in a Colombian toilet [...] Every cell in my body is coming to a total, terminal stillness. Panic detonates into endlessly expanding terror.

And so, unable to embrace his foretold Colombian death, Thompson returns "home," by bringing to mind his wife and child left in Australia, right before losing consciousness. The yagé and Colombia, in the end, provide him with a second chance in life, and, more importantly, with a "new self" able to return home: "Truly, I am born again, and this time 
not in the ignorance of childhood, but in the blooded, branded, beautiful freedom of the escapee" (319).

A different kind of escapism (away from home) can be found in Michael Jacobs's The Robber of Memories. ${ }^{20}$ Set up as a memoir of travel along the Magdalena River, this travelogue is a personal meditation on the Alzheimer's and dementia suffered by the author's parents, which Jacobs uses to link Colombia (a land where "memories are illusory") and the author's home in the UK (where memories have faded as a consequence of his parents' degenerative diseases). In this travelogue, Colombia is sought not as the place to encounter death, but rather as a place for memories, more precisely as the place to embark on a journey of memories. Jacobs sets out to explore memory "as a source of mystery and awe" (14), following the upstream trajectory of the Magdalena River from Barranquilla (Atlántico) to San Agustín (Huila). His fluvial itinerary is inspired by García Márquez's novel El amor en los tiempos del cólera (1985), which closes with the "endless" love journey of the two elderly protagonists (Fermina Daza and Florentino Ariza) back and forth along the Magdalena River under their ingeniously self-imposed cholera quarantine. ${ }^{21}$ Jacobs uses an excerpt (in the form of an epigraph) from this closing scene to open his travelogue: “... and he realized that the Magdalena, father of waters, one of the greatest rivers of the world, was only an illusion of memory." The pursuit of such an illusion amidst the magical and gruesome Colombian realities that Jacobs is to encounter along the river journey will occupy much of his travelogue.22

River memories of the kind emerging from García Márquez's novel are both embraced and dispelled in Jacobs's account. In The Robber of Memories the Madgalena is a conflation of natural beauty- "an unforgettable finale of tropical mountains and moorlands"-, socio-political dangers and violent history that have a "drug addictive" effect on the traveler (157). It is also a dumping ground for victims of the armed conflict between guerrillas and paramilitaries, a burial site for the disappeared and for the robbed memories left behind, which remind Jacobs of those who are disappearing in his life back home: "I was thinking of the disappeared, of the accumulation of absent presences in my life, of the thousands of missing victims who haunted the Magdalena" (172-173). Thus, the life and death that Jacobs encounters along the river help him build a linkage between personal memory ("the absent presence" in his life) and the historical loss of memory haunting the nation, as nameless victims piled up along the riverbanks. Jacobs's interest in exposing the crimes and human rights violations of guerrillas and paramilitaries has to do precisely with his quest for reclaiming the lost memories of those who have endured the massacres of the armed conflict.

In the process of reclaiming the memories that have been taken away, Jacobs often reverts to memories of home life in the UK, particularly those relating to the "absences" endured by both his parents. It is through this constant reflection on the loss of memory (individual or national) that 
Jacobs manages to "write home" (to inscribe home in his narrative) while being away in Colombia. This home and away linkage is seen through the town of Yarumal (Antioquia), whose population-due to a rare genetic mutation dating back to 18 th-century Spanish migrants-has one of the highest rates of early onset Alzheimer's disease in the world. This so-called "el pueblo del Alzhéimer" fascinates Jacobs for reasons that go beyond the linking of Colombia with his father's terminal illness. ${ }^{23}$ Formerly a hotbed of guerrilla fighting and gruesome violence, Yarumal provides an uncanny living parallel to the famous "memory loss" episode in Cien años de soledad, when the inhabitants of Macondo collectively suffer from insomnia and, subsequently, memory and language loss. And, similarly, it emerges as an exemplary case of the loss of historical memory: it is now the collective memory loss emerging from violent conflict that is betoken by the proliferation of the disease. By placing the story of Yarumal centrally in the travelogue's section titled "The Disappeared," Jacobs amplifies both the meaning of disappearance in the context of Colombia and that of memory loss as an illness. Furthermore, and in this not unlike other Colombian travelogue writing, he relies heavily on magical realism (e.g., a town without memory at the mercy of both the guerrilla and a rampant mental disease) as a device that allows him to write about what he perceives to be the unfathomable reality of Colombia. ${ }^{24}$

Despite Jacobs's primary concern with "memories being robbed" or taken away by disease or violence, his travelogue also seeks to provide some level of global awareness, or even advocacy, concerning the harsh realities taking place on the ground in Colombia. As much as he is caught up in his own melancholy journey away from home and among the natural wonders of Colombia, he is also committed to expose the atrocities carried out by guerrillas and paramilitaries. As he approaches the Magdalena's source in Páramo de las Papas, "that place of legendary beauty" (225) now surrounded by guerrilla activity, the travelogue shifts toward descriptions that make his personal journey one involving the collective interest in human tragedies of displacement and death:

It was a landscape of ghosts and tragic memories, of killings and kidnappings, of farms taken over by the FARC, of children robbed of their homes, of army searches and reprisals, of inhabitants who had learnt to survive by not telling anyone anything.

Coincidentally, the darker side of Colombia Jacobs wants to show his global audience is precisely located near the Magdalena's source in Páramo and the nearby town of San Agustín, where he fears most the presence of the FARC. The river journey from mouth to source, then, is illustrative of the beauty and tragedy that Colombia has become for many travelers. But, more importantly, for travelers like Jacobs (and, to a certain extent, Thompson) Colombia is the place from which these 
visitors are able to return home and continue with their lives after having had the chance to experience the darkest side of the country:

I had travelled to the one entrance of the Underworld, where I had drunk form the waters of Forgetting, and not from Memory. And now I was being punished. By being made to return to earth, to learn all over again.

By embarking on an initiating journey that induces forgetting, not remembering, Jacobs's travelogue poses whether forgetting refers to forgetting home and family or to the forgetting of historical violence, which is at the crux of efforts toward reconciliation in Colombia.

\section{The Boom of Colombian Travelogues}

As we have seen in the travelogues of Smith, Chao, Thompson, and Jacobs, fear, terror, beauty, and magic seem to be the attributes of Colombia that the global cultural market seeks to perpetuate in order to sell them to international audiences. All these travelogues, however, present varying degrees of advocacy on behalf of the victims of the armed conflict, and therefore should not be simply disregarded as market-generated travel books for leisure reading. While Colombian travelogues present known patterns and skewed views in Latin America travel writing-e.g., the irremediably conspicuous presence of the imperial "I/eye," the primacy of the observer's voice over the subject being observed-, they also serve to provide global readers with alternative representations to the film and TV versions of Colombia. I am perhaps being somewhat naïve about the reach and impact that some of these travelogues actually have, and about how they are being read or if they are being read at all. But, as I mentioned in the introductory section of this chapter, one of the reasons for the recent boom in travelogues has to do with the genuine interest of global readers in cultural difference and diversity, and in the exploration of that which is distantly foreign, strange, or unknown to them.

Colombian travelogues are well suited to respond to such market demands, and I expect that, as security concerns ease somewhat and more foreign "Is/eyes" descend into the country's remote areas, we are bound to see more of such writing. Or, at least, that was the case before international travel was interrupted by the COVID-19 pandemic. Once international travel resumes, I would expect to see a majority of these travelogues to be of the "report-from-the-front" kind, as suggested by the 2000s production output. Recent travelogues such as Tom Feiling's Short Walks from Bogotá (2012), Garry Leech's Beyond Bogotá (2009), Nicholas Coghlan's The Saddest Country (2004), or Steven Dudley's Walking Ghosts (2004) have appeared in a wide variety of pressestrade and academic (Penguin, Beacon, McGill, Routledge)—with diverse 


\section{The Travelogue Boom}

reading audiences, and are good examples of this current market trend and of the market diversification of travelogues. ${ }^{25}$ While these books have different purposes and scopes, their authors share a common bond of advocacy for victims in Colombia. The fact that their books also benefit (and profit) from the overall travelogue boom in which Colombia plays an important part is not without importance, though, especially given that most recent travelogues are widely accessible in digital format.

As opportunistic as some of these recent travelogues may sound, then, I think it is worth exploring the reason(s) why they are being published and distributed in the global market. One example, Short Walks by Feiling - a British journalist who worked for the NGO "Justice for Colombia" and produced the documentary Resistencia: Hip-Hop in Colombia (2001)-, seeks to expose the harsh life conditions of Colombia's rural areas subjected to paramilitary and guerrilla warfare while providing readers with insights into the "new Colombia." Feiling's detailed account does provide a wealth of historical information about how armed groups like the AUC, ELN, and FARC were formed and what kinds of interaction they have had with different sectors of the population and various governments since they first appeared. His interest in exploring Colombia's "Violentology" provides international readers with a multi-layered analysis of the so-called actors of the conflict (drug traffickers, kidnappers, guerrillas, and paramilitaries). But, more importantly (from the cultural market's angle), Feiling tells his international readers that despite the violent acts that dominate "old" Colombia, the new 21st-century Colombia has all the makings of a success story (at least, "on paper"), thanks to its wealthy resources (minerals, wind, water, farm land, biodiversity) (ch. 10; loc. 3356). It is, then, a country that is potentially different from the one portrayed in the media and, therefore, worthy of exploration.

Likewise, it is a country that is different from the one he encountered in 1999; now it seems anchored in the renewal and repetition that international readers may recognize thanks to having read García Márquez's Cien años de soledad:

Twelve years later, growing numbers of foreigners are discovering the bounty of Colombia. Despite the ragged contours of its national history, it seems destined to emerge from its years of solitude to come. The world is in for a treat when it does.

(ch. 11; loc. 3695)

Therefore, Feiling's travelogue wants to appeal to readers' (and travelers') desires to (re)discover a new land of vast resources and incomparable beauty that is ridding itself (or, at least, trying) from its tainted image and past, although still subject to "years of solitude" in both its future and past. 
Dudley's Walking Ghosts and Coghlan's The Saddest Country deviate significantly from the magical realism bandwagon and from what some would consider a standard travelogue. Both titles, published by academic (or academic-oriented) presses in 2004, obviously have broad appeal for international audiences interested in advocacy and human rights abuses, as they document their authors' on-site experiences in Colombia during the country's violence upsurge in the 1990s. Coghlan-a former Canadian Embassy employee who participated as a guest of the NGO Peace Brigades International-sets out to report on and explain why "Colombia deserves not just our horror but our sympathy" (5). Moving away from the description of beautiful landscapes, this travelogue is an exposé of the "impunity for crimes of all kinds" that has defined the country's recent history. For his part, Dudley_who, coincidentally, came to Colombia in 1995 as a member of Peace Brigades International-focuses on the demise of the leftist Communist Party in Colombia, Unión Patriótica, and the horrors that ensued once most of its leaders (and members) had been wiped out amidst the violence of the 1980s and 1990s. As he travels the country to document, for instance, the pro-communist union in Barrancabermeja's oil-refinery (a hotbed of guerrilla and paramilitary activity), he reaches out to what he calls Colombian "walking ghosts." These are "people who have crossed the death's frontier," "are still alive" but wish they "were dead" because the armed conflict has "cornered them" and forced them to live in a world of "wakes and funerals" (11). As one can surmise from these succinct descriptions, Coghlan and Dudley intend to reach higher ground with international audiences, and do so by explaining the socio-historical importance of their journeys of advocacy in that they are above the fray in relation to most "travelogues of fear and death"-the very genre that their books' titles seem nevertheless to reference.

International audiences may also find a similar degree of advocacy and of distancing from magical realism portrayals when reading Garry Leech's Beyond Bogotá. Although not a travelogue stricto sensu, the book (a cross between a personal memoir and a diary) is based on Leech's 11-hour detention at the hands of the FARC in 2006. Structured in 11 chapters (supposedly corresponding to each hour of "confinement"), the book provides little or no information about the reason for his detention, release, and/or his state of mind while being detained. ${ }^{26}$ Instead, in each chapter Leech wanders in his mind around the parts of Colombia he has visited in the past, while reflecting on the civil war afflicting the nation and addressing some possible solutions. For instance, he decries the US economic and military interventionism in Colombia (111-112), denounces the assassinations of union leaders and the subsequent impact on workers' rights (195), and exposes the environmental degradation and its effects on natural resources for Afro-Colombian and indigenous communities in La Guajira (202).

Marketed as a compelling and thorough account of the realities on the ground such as providing "fresh insights into US foreign policy, the role 


\section{The Travelogue Boom}

of media, and the plight of every day Colombians caught in the middle of a brutal war" (back cover), Leech's book offers a rather skewed picture that categorically condemns the acts of paramilitaries (and their statefunded interventions) while being somewhat sympathetic to the cause of the FARC (which, incidentally, is the topic of his next book). His "diary of a drug war" (as the subtitle indicates) overemphasizes his "unfortunate" encounter with the FARC, and it also provides a "false sense" of traveling throughout Colombia, which Leech and (presumably) his publisher have opportunistically turned to with a view to competing in the current boom market of Colombian travelogues.

Under neoliberal policies, new markets must be opened in order to continue to satisfy the unprecedented demand for travel and travel writing that defines the global era. Colombia offers itself as the ultimate frontier for new, more adventurous, and/or more socially aware travelers. At least, this is the idea being disseminated in recent Colombian travelogues and in the manner in which they are being reviewed by major newspapers. The boom of Colombian travelogues inspires also a reflection on the extent to which the travel industry favors a diverse portfolio of destinations, one that includes sites of pure leisure as well as dark tourism and humanitarian advocacy. Colombia provides travelogue writers with a unique combination of opportunities-for global advocacy in reference to social conflict and crises, for extending awareness of human rights violations, but also for describing captivating landscapes, and for exploring social diversity and heterogeneity.

\section{Notes}

1 The term travelogue is now common currency in travel writing scholarship. Given the recent plethora of internet blogs, personal travel narratives, guidebooks, and so forth, travelogue can be used as an umbrella term that subsumes the various manifestations of travel writing: "a speech, movie, or piece of writing about someone's experiences while traveling" (Webster's Dictionary).

2 Other titles could be included in this list given that almost any recent book about Colombia tends to replicate-at least in the title-the darker side of the country: e.g., Nicholas Coghlan's The Saddest Country: On Assignment in Colombia (2004), Steven Dudley's Walking Ghosts: Murder and Guerrilla Politics in Colombia (2004), June Carolyn Erlick's A Gringa in Bogotá: Living Colombia's Invisible War (2010), Terry Gould's Marked for Death: Dying for the Story in the World's Most Dangerous Place (2009), or Sibylla Brodzinsky and Max Schoening's Throwing Stones at the Moon: Narratives of Colombians Displaced by Violence (2012). While my focus in this chapter is on how the Colombian conflict is viewed from the outside through travel writing, it is worth referencing "in-house" narratives that have widely circulated beyond Colombia such as Silvana Paternostro's My Colombian War: A Journey Through the Country I Left Behind (2007), Alfredo Molano's The Dispossessed: Chronicles of the Desterrados of Colombia (2005), and 
Juanita León's Country of Bullets: Chronicles of War (2009). The last two were originally published in Spanish.

3 Blanton traces travel writing from the 13th century and Marco Polo onward, providing us with a historical development of the genre within the interplay between the narrating I/eye's cultural parameters and the "discovery of others" taking place during the journey. For Blanton, there is an important distinction to be made between "impersonal narratives" (linear, flat, chronological) and "consciously crafted" travel narratives that often borrow from figures and tropes akin to fiction. In the case of Colombia, the latter seems to be more pervasive. In terms of the evolution of the genre, Blanton sees a tendency (starting in the 1950s) toward travel narratives of disillusion, annoyance, boredom, and even anger (25; referencing Fussell's "Post-tourism" narratives).

4 In this connection, Holland and Huggan argue that "travel narratives strike to express the unfamiliar, but also return to it; in scanning the past, they compile an inventory of domesticated mysteries, and yet they are made to confront the unexpected strangeness of the present" (24).

5 I am drawing here on the following works: John Lennon and Malcolm Foley's Dark Tourism: The Attraction of Death and Disaster (2000), Graham Huggan's Extreme Pursuits: Travel/Writing in an Age of Globalization (2009), Richard Sharpley and Philp Stone's The Darker Side of Travel (2009), and Jonathan Skinner's Writing the Dark Side of Travel (2012).

6 Lennon and Foley's argument is "that dark tourism is an intimation of postmodernity" driven by global technologies and anxiety and doubt about modernity (11). Skinner, while revising the contributions of Lennon and Foley, sees in "thana-tourism literature" and "dark tourism" conduits for mediation between the living and the dead, and for the hope of "a good death," which is why worldwide tourists flock to Holocaust Museums or Lady Diana's accident site in Paris (4).

7 Holland and Huggan argue that travel writing is

a commodity that cries out to be purchased and consumed and purchased again [...] It is as if this cycle of production, consumption, and reproduction were at the genre's core; and as if repetition were the paradoxical gesture that both marked and warded off the risk of its demise.

8 Ramón Chao's travelogue has appeared in relatively unknown publishing houses: Un train de glace et de feu was published by Edition de la Différence in Paris. Route published the English version The Train of Ice and Fire (translated by Ann Wright) in the UK, and El Europeo y La Tradición published the Spanish version Un tren de hielo y fuego in Madrid. Another Spanish edition was published in 2001 in Valencia by Cybermonde with the title Mano Negra en Colombia: un tren de bielo y fuego. These are, for the most part, presses with small distribution networks, which resulted in keeping this travelogue out of major circulation until the digital/Kindle edition appeared in September 2010. This is arguably the moment in which the travelogue went global.

9 The Chao family background is important here for their connections in both continents. The patriarch is a Galician immigrant who worked as chief editor for Latin America at Radio France Internationale. Prior to their 1993 Colombian train journey, Mano Negra had toured Latin America by ship 


\section{The Travelogue Boom}

as part of the band's "Cargo '92" enterprise, when they visited Argentina, Uruguay, Brazil, Cuba, and the Dominican Republic. The 1992 trip produced the travelogue Il était une fois ... cargo 92: Royal de luxe, Mano Negra, Philippe Decouflé, Philippe Genty sur la route de Christophe Colomb (2013).

10 As Chao reminds us, this demise coincided with the privatization of railways and the upsurge of the national airline Avianca, which, in effect, not only changed the nation's transportation system but as well affected its social mobility and national fabric. The Colombian railway system reached about 3,200 kilometers in its peak, of which only 1,600 are viable tracks today. The only train line that is functioning today is that of Bogotá to Zipaquirá, a tourist route to the Salt Cathedral (26). With the exception of this touristren, the national passenger network system was suspended in 1992. There have been efforts since then to revive some of the existing train lines, mostly through international investors.

11 Not only is García Márquez's Cien años de soledad (1967) an important reference for Chao's travelogue and for his understanding of Colombia, but almost every single travelogue included in this chapter references García Márquez's oeuvre as informative of a magical realist vision of Colombia. For Smith's references, see pages 109, 139.

12 The following is another instance where the colonial voice appears in Chao's description of the nation's natural resources: "Colombia is lucky enough to have infinite resources. Its subsoil has emeralds and other precious stones, huge reserves of bauxite, potassium, and copper. Oil exports started in 1986 with an annual production of 18 million tones" (162).

13 Smith has also published The Land of Miracles: A Journey Through Modern Cuba (1997) and Underground London: Travels Beneath City Streets (2004). Each of these titles broadly adheres to "magical" and "gritty" views in travel writing. In addition to his travel writing, Smith has contributed to the London Review of Books and Channel 4 news in the UK.

14 Smith provides a good deal of information and commentary related to violence in Colombia, which reinforces his point about the darker side of Colombia. In the opening chapter, he mentions, for instance, that "Colombia kills more of her own than the United States by nine times" (8), that "'massacre' has entered the language of demographics in Colombia" (9), that 80 out of 100,000 people face an untimely death and that police records show 36,000 violent deaths in 1998 and 32,000 in 1997 (9). Similarly, Smith provides international readers with historical information about armed groups like M19, FARC, or ELN (112-113; 116-117). This information aims to validate his preconceived ideas about the national ills of Colombia. Smith's brief history of Colombia's guerrillas is interspersed with reminders of the train and of darkness: "The train passed through the cool darkness of a clay tunnel" (117). Again, through the train, Smith reconstructs the national history (a history of violence and demise).

15 Smith is interested in documenting the importance of the railway system for Colombia's economic prosperity and, for that purpose, he includes information that validates the economic benefits train transportations once had for the nation. His incursions into economic development and the great potential for Colombian growth typically fall within the parameters of (post)colonial travel writing and extractivist descriptions that survey the nation's potential resources (one of the original aims of travel writing in Latin America): 
The Ferrocarril de Antioquia first ran in 1893 [...] The result was a boom in coffee export: Colombia was established as the world's leading producer of Arabica or mild beans, many of them grow in Antioquia. Nor did the expansion end there. The first big textile mill opened in Medellín in 1906, and within a few years, the city was full of cotton factories.

16 Smith argues that there has been an "unbroken line" of violence since the years of La Violencia and points out that "evidence appeared to be that drugrelated violence lagged behind other causes of summary morbidity, including out-and-out lawlessness" (145).

17 My Colombian Death was first published in Australia in 2008 (Picador/Pan Macmillan), and began to circulate in other Anglophone book markets in 2009, which coincided with the launching of the digital edition. Thompson's travelogue has not been translated into Spanish, and there are no holdings of it at any major Colombian libraries.

18 Mancuso, in Thompson's words, "is the commander-in-chief of a 30,000strong underground army steeped deep in atrocities" (204): "He projects the casual, playful but aloof air of a man who grew up rich more than he does the menace of a bloodstained warlord" (205).

19 Another Australian, Michael Taussig (not mentioned in Thompson's book), has written about the yagé experience from an anthropological viewpoint in My Cocaine Museum (2004) and Shamanism, Colonialism, and the Wild Man (1991).

20 Published by Granta Books in the UK in 2012, The Robber of Memories (also available in digital format since 2013) is marketed as a "travel companion" for travelers who are more interested in socio-historical information about Colombia. The author, Michael Jacobs, has written several travel books on Spain, France, and the Andean region.

21 As it is customary in contemporary Colombian travelogues, Jacobs's travelogue also includes references to Cien años de soledad (7-9; 195).

22 The documentarian Nicolás Rincón Gille also explores life and death along the Magdalena River in his 2010 film Los abrazos del río. As in Jacobs's travelogue, Rincón exposes the river's transformation from a place of sustenance and mythology for locals to a burial site.

23 Jacobs learns about Yarumal thanks to his encounter with the writer from Medellín Héctor Abad Faciolince. In particular, Jacobs is interested in Abad's memoir El olvido que seremos (2006) - a tribute to Abad's father who was slain at the hands of paramilitary forces_and the article "El pueblo del Alzhéimer," which "dealt with the proliferation of the disease in a district a hundred kilometres north of Medellín" (Jacobs 193). Abad's memoir has been translated into English as Oblivion (2010) and also turned into a documentary titled Carta a una sombra/Letter to a Shadow (2015) and, more recently, into a film directed by Fernando Trueba (2020).

24 Another episode of Colombian life that Jacobs mediates through García Márquez's brand of magical realism is his brief encounter with a FARC deputy commander near Yarumal. When the unnamed commander claims that "the FARC was now intending to be a leading promoter of tourism in Colombia," Jacobs feels he is "experiencing an absurd dream" that can only be explained with the help of García Márquez’s fiction: 
I had strolled into the pages of One Hundred Years of Solitude, witnessing a war that no longer made any sense, a war based on rapidly diminishing memories of how it had started, a war that was kept going almost mechanically, mindless of its shifting, ever more confused objectives.

25 Some of these authors are not neophytes to Colombia, having lived and published about Colombia before. See, for instance, Feiling's Cocaine Nation: How the White Trade Took Over the World (Pegassus, 2009; orig. The Candy Machine: How Cocaine Took Over the World; Penguin, UK, 2009) and Leech's The FARC (Zed, 2011). Arguably, Feiling and Leech have cashed in on the current boom of Colombian travelogues. Another title in this list of travelogues about Colombia is Glen Heggstad's Two Wheels Through Terror. This is a fairly unknown travel diary by a former US army soldier, martial arts teacher, and a "biker dude" who gets detained by the ELN in Colombia. Heggstad comes across as a poorly informed traveler who constantly positions himself as smarter than the guerrillas and, obviously, as their "superior" coming from the North. For the travelogue's section devoted to Colombia, see 83-172.

26 Leech does not address directly the reasons for this detention. But he does provide readers with some important background information that would make him a potential enemy of the FARC: he is a British-born American who served for 18 months as a US Marine in the Panama Canal, where he participated in the US Special Forces. Nevertheless, he disavows any allegiance to the US military:

I quickly grew to detest the dehumanizing, desensitizing, and tedious nature of military life and responded to it by becoming increasingly disobedient to my superiors [...] Many years later, I would come to realize just how oblivious I was of the political and social realities of Panama. 


\section{Affective Visuality \\ The Cinema of Conflict and Reconciliation}

Is tactility necessary to achieve reconciliation? I begin this chapter with this question to situate the importance of touch in practices of reconciliation. Typically, reconciliation includes a tactile experience-a handshake, a hug, or an embrace-to indicate some level of closure or finality of the conflict. Colombian films in the last two decades have employed visual grammars that precisely focus on tactility and proximity between victims and victimizers (or between opposing parties in a conflict). "Touching the other," as it were, has become a recurring trope in recent films and thus activated affective practices in the film viewing experience as an intended conduit to achieve national reconciliation. By deploying tactility as one of its primary visual dispositives, these new films explore the relationship between spectators and film subjects creating a new form of knowledge that is, in principle, more egalitarian and less hegemonic. This type of visual relationship is conducive to connecting with others and, ultimately, fosters reconciliation. As the visual display moves away from the explicit deployment of atrocities and crimes on the screen, the film viewing experience triggers a "feel for the other," "a feel for the conflict" - in a nutshell, feeling the conflict takes primacy over seeing the conflict.

As Laura Marks proposes in The Skin of the Film (2000), tactile visuality seeks to directly relate the objects touched with the memories, the silences, and the absences that are evoked through them. And this is precisely what we experience in contemporary Colombian cinema: we see the conflict through memories, silences, absences, and through eye contact with the celluloid. Affect in film viewing is triggered through tactile experiences, through textured images in which the eye is exposed to non-traditional forms of visuality such as the haptic-broadly defined as the sense of touch or tactile perception. Tactile visuality often makes us experience partial viewing as the film's images are purposely obscured by granulation, darkness, grayness, incompleteness, or blurriness. The point being-as Marks suggests—that we as film viewers are, at first, confused about what we see (or rather don't see) on the screen and about the apparent lack of a cohesive filmic narrative. In contradistinction to optical visuality, which "assumes that all the resources the viewer

DOI: $10.4324 / 9781003195702-5$ 


\section{Affective Visuality}

requires are available in the image," in the haptic image we are forced to "contemplate the image itself instead of being pulled into the narrative" (Marks 163). Thus, we often have to complete or supplement the partial or obstructed viewing and the "gray areas" displayed on the screen, and to do so, we engage the filmic narrative through an ocular contact with the so-called "skin of the film" as textures need to be discerned.

Giuliana Bruno reminds us in Atlas of Emotion (2002) that the haptic, as its etymological root suggests-[ "able to come into contact with" (6)]allows us to come into contact with people and the surface of things. She establishes a series of links between haptic perception, touch, and affect that ultimately relate to the conceptual tandems sight/site and emotion/ motion: "Thus, while the basis of touch is reaching out-for an object, a place, or a person (including oneself) -it also implies the reverse, that is, being touched in return" (254). In this motion of touching and being touched in return-and the affective practices imbued in this process-is where I intend to frame my reading of recent Colombian cinema and how it addresses conflict and reconciliation.

Optical visuality has long dominated the Colombian filmscape, offering audiences films that portray the armed conflict simplistically, often showing the harsh realities of the conflict through realistic depictions of violence and warfare in which "good" and "evil" are clearly established. Recently, however, there has been an important shift to dismantle hegemonic narratives about the armed conflict and to represent it through more complex visual grammars and filmic plots that are informed by tactility and haptic images. This shift, in my view, has to do with several convergent factors: the historical movement toward national reconciliation, the upsurge of academically trained Colombian filmmakers, governmental funding and support for the expansion and distribution of Colombian films, the audience's fatigue with mimetic (and often crude) representations of violence that polarize the armed conflict, and the advent of global platforms for film distribution.

Exemplary cases of this shift toward complex (read multi-sensorial) visuality in Colombian cinema can be found in the visual grammars being displayed in contemporary films such as La sombra del caminante (Ciro Guerra, 2004), La sirga (William Vega, 2012), La tierra y la sombra (César Acevedo, 2015), and Violencia (Jorge Forero, 2015). In them, conflict does anchor the filmic narrative and remains an important element in the visual display, but there is a shift toward occluding the conflict and the moving image that represents it. Visual occlusion is commonplace in these films as dust, fog, mist, rain, ash or vegetation impede our full view and diffuse the primacy of optical visuality. Instead, recent Colombian films often display their subjects and objects in penumbra and through black and white or grayscale to break away with the notion that a "complete or full picture" about the Colombian conflict and its processes of reconciliation is tenable. As we know, given the complex history of civil unrest, conflict, and warfare in Colombia, any attempt to provide a full 
view is doomed to fall short. That is why recent Colombian filmmaking seeks to embrace and explore that very impossibility through partial viewing to expose Manichean narratives about the nation's violent past and present history.

To begin my discussion I have chosen some illustrative image pairings from La sirga, La tierra y la sombra, and Violencia that show how visual occlusion and partial viewing are now being deployed to portray conflict and reconciliation in Colombian cinema. It is important to note that the similarities in the visual composition (e.g., backlighting, occlusion) are not simply coincidental but rather point to a recurrent approach to filming the conflict: how we see it and what we do not fully see matter to effectively (and affectively) expose the gray areas in the processes of reconciliation.

In the first image pairing (Figures 4.1-4.2), the characters appear embedded in their natural habitats as weeds and sugar cane stocks are forefronted to impede our full view of their faces. Film viewers are thus invited to consider how these textures relate to the film subjects who are anchored in specific rural areas of conflict in Colombia (i.e., weeds from La Cocha Lake in Nariño, sugar cane fields in Valle del Cauca) where nature seems to envelop and oppress their inhabitants. Rural environs (which have long been the primary localities for the Colombian armed conflict) in effect take over the image composition in these films to indexically mark the complexity of the characters' struggle with their natural habitats in the midst of warfare. The dominance of oppressive vegetation over human survival and subsistence in Latin America is not an entirely new trope, but in these films the natural textures and their granulation are deployed on the screen as markers of such a struggle. First, viewers see lined-up weeds and stocks (as it were) scratching the image

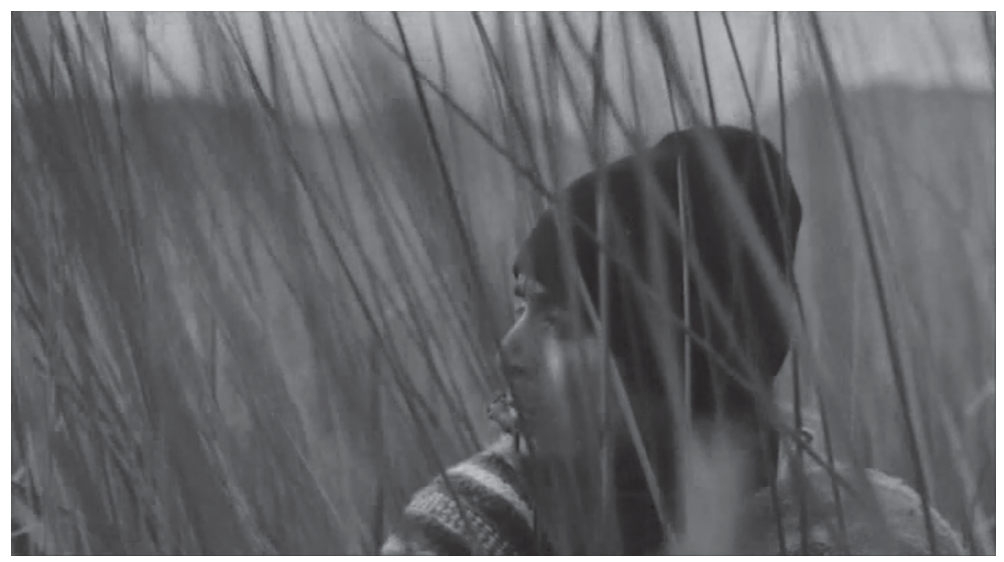

Figure 4.1 Mirichis in La sirga (screenshot). Contravía Films. 


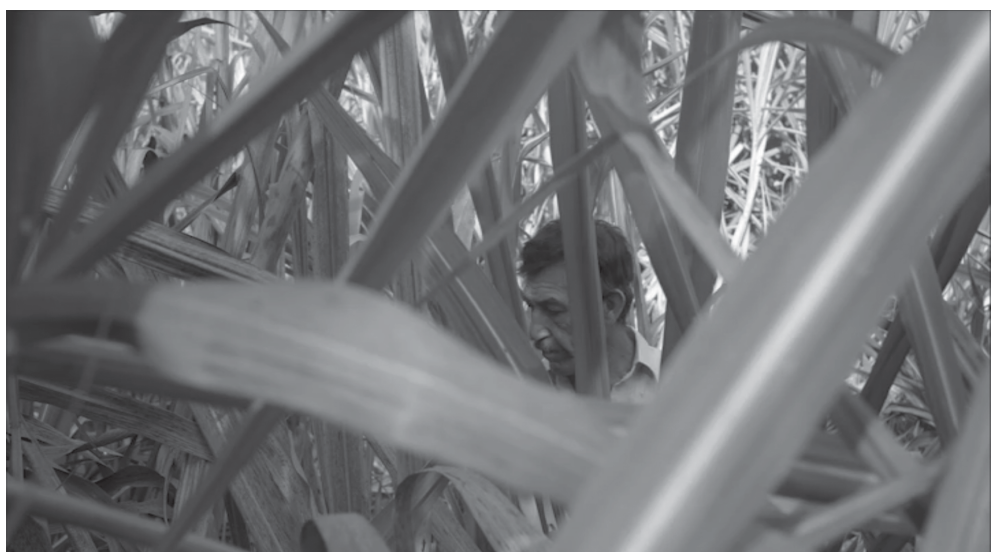

Figure 4.2 Alfonso in La tierra y la sombra (screenshot). Burning Blue Films.

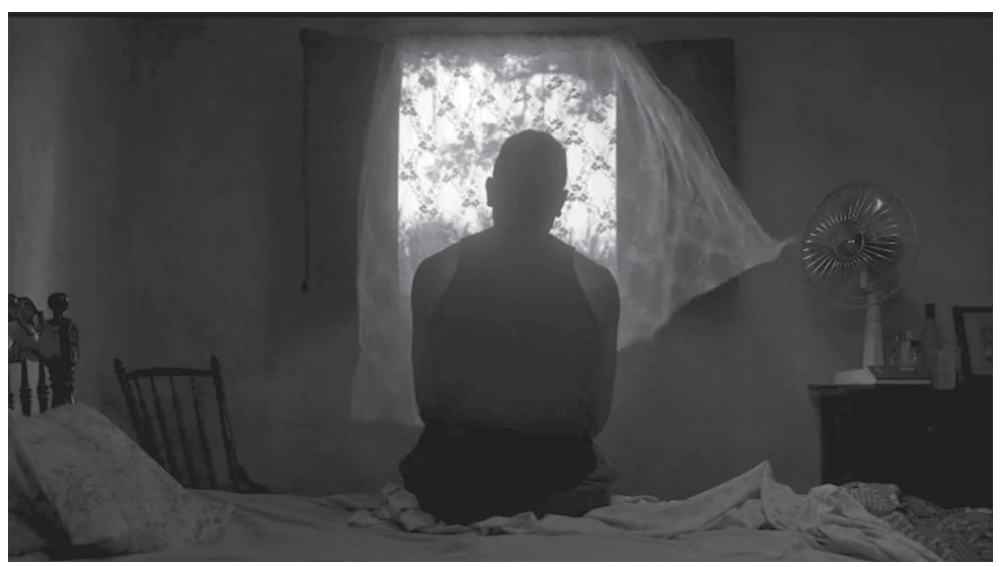

Figure 4.3 Gerardo in La tierra y la sombra (screenshot). Burning Blue Films.

surface and the protagonists' faces. While there is no total occlusion or darkness in these images, we as spectators cannot fully grasp the contours of the protagonists' faces as they remain incomplete before our eyes. This, in effect, activates our visual response to fill in the gaps in the images, triggering our tactile eye to engage with the surface, with the "skin of film."1

The second image pairing (Figures 4.3 and 4.4) offers a different take on the haptic display. Through a darker image composition, spectators barely see what is being displayed on the screen. These images show the film subjects as dark silhouettes against the white light coming through laced and patterned curtains. Their proximity to death in the filmic 


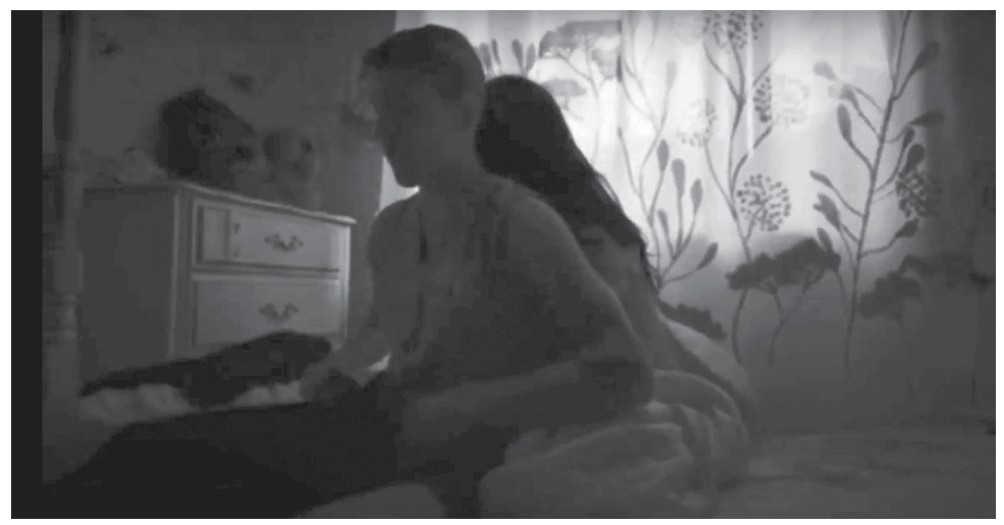

Figure 4.4 Falso positivo in Violencia (screenshot). Courtesy of Jorge Forero.

narrative is enhanced by the light coming from the outside barely illuminating the room (and the objects in it) as darkness takes over the images. To seek clarity, film viewers are drawn to the textured patterns on the curtains that filter the light into the room and into the characters' final hours. Here again, we are asked to interact with the textures in the image, with the surface to look for clues trying to discern what we see and can barely see. In one instance, the laced curtain against which the protagonist is breathing indexically marks his fatal respiratory illness; in the other case, the unnamed young man's dark body against the wild weeds pattern on the curtain anticipates the open field (far away from the city) in which his extrajudicial killing will take place a few hours later. These tactile visual compositions establish a clear correlation between the occlusion and darkness on display and the characters' story and resolution in the filmic narrative.

My interest in exploring haptic visuality to address filmic representations of conflict and reconciliation in Colombia has to do precisely with the lack of completeness or fullness in the moving image, and with the visual exploration of unstable spaces that are not clearly confined within welldefined cartographies. In this regard, Juliana Martínez has proposed to read visualization practices in Colombian film as instruments "in shaping the perception of the world and in legitimizing neocolonial cartographies that distribute resources and rights unevenly" ("Competing Visions" 122). This can be seen in films such as La sirga, where visual impediment emerges as the primary mode of visuality since "seeing is not easy" and images are "either too open or too closed to ascertain what is happening" (124), as Martínez reminds us. Thus, the representation of conflict in Colombia and its potential resolution is not easily ascertainable, more so when recent films are precisely trying to underscore the impossibility of "closing off" the decades-long conflict. 


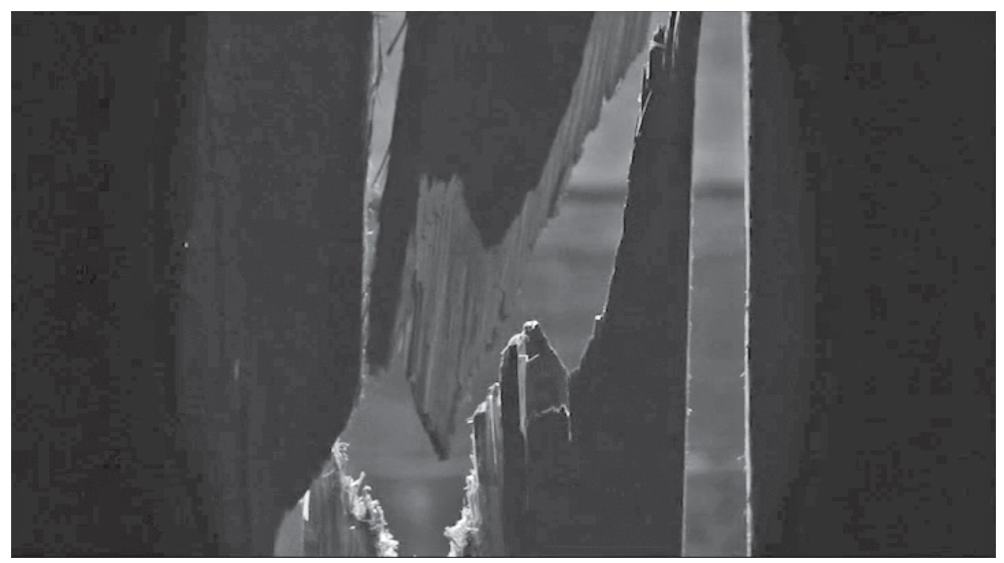

Figure 4.5 La Cocha Lake seen through broken wood in La sirga (screenshot; nighttime). Contravía Films.

The visual restrictions we see on the screen relate to the challenges in accessing these new geographies, which, ultimately, signals that the coveted peace process is, at best, in a transitory phase. For instance, the characters in La sirga live in an eerily quiet community in La Cocha Lake, which is obviously going through the difficult transition from conflict to promised peace. The village in the film is made up of local fishermen whose subsistence is being threatened, on the one hand, by the neoliberal economy's demands for an industrial farm fishing project, and, on the other, by the threatening appearance of armed groups in the region. The protagonist's arrival to her uncle's inn precisely coincides with the inn's renovation and with the hope of tourists returning to the lake-clearly an implicit reference to the government's promise for a safer and peaceful Colombia where tourism can reach remote areas of the country.

As we can see in Figures 4.5 and 4.6 the geographical contours of the lake in which the film is thematically and visually anchored often remain occluded to the viewer through dark light or perennial mist. Materiality and reconstruction take center stage in a great number of stationary shots throughout the film as constant reminders of the inn's (and, by extension, the country's) decay. Closeup shots of broken wood, shattered glass windows, and rusty tin roofs-all indicative of the dire need for renovation-bring the viewer's eye into contact with the surface of the film. Adding to this, the constant detailing and touching of surfaces in need of repair by the characters in the film enhances our multi-sensorial view of the reconstruction efforts (read national reconstruction).

Exploring the significance of multi-sensorial perception, Juliana Martínez argues that the Deleuzian distinction between striated and smooth spaces duly applies to La sirga. The former are stable and 


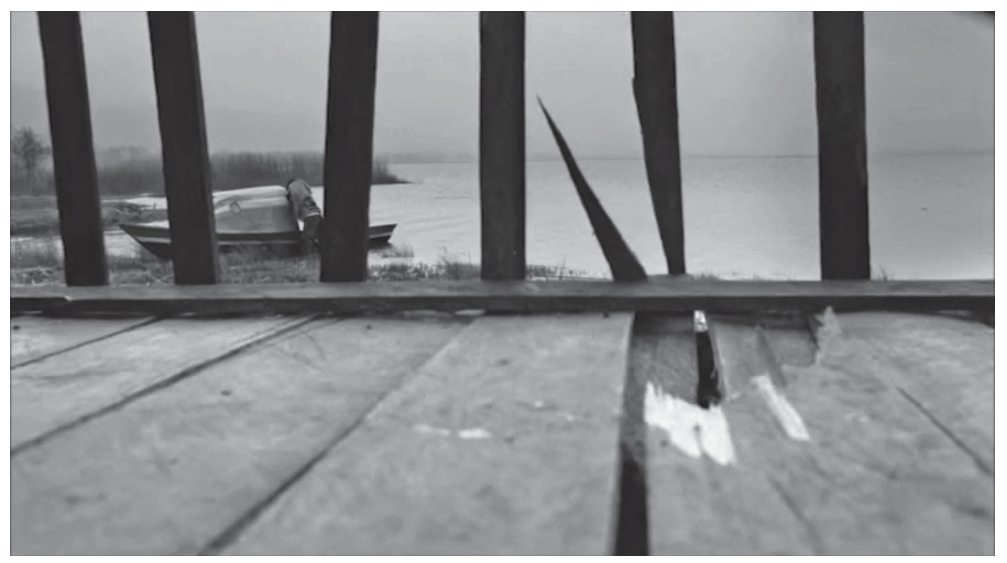

Figure 4.6 La Cocha Lake seen through broken wood in La sirga (screenshot; daytime). Contravía Films.

productive surfaces that offer centrality (and, implicitly, the state's control), while the latter prioritize the desire to see and cannot be entirely contained by established measuring systems. Martínez's focus is clearly on the connections between visual impediments (such as fog or mist) and the fantasmatic (dis)appearances in the film that ultimately contribute to limiting our vision and to the overall blurriness in the storyline and in the moving images on the screen. In this context, she argues that the haptic perception in La sirga provides audiences with more holistic sensory film viewing experiences that "prioritize and rely on a scopic regime" of desire and knowledge ("Competing Visions" 124-128). The haptic perception of these smooth spaces-in contradistinction to striated spaces "defined by long-distance vision" (125)—and the visual impediments typical of haptic perception invites viewers to engage into "a holistic and reflective way of relating to the environment" (126) and, ultimately, to confront the impossibility of measuring and mapping the boundaries of the new cartographies on display. ${ }^{2}$

Tactile visualities such as the ones in the selected images from La sirga, Violencia, or La tierra y la sombra abound in recent Colombian cinema and privilege materiality that exposes textures in the film while inviting us to consider the relation between the spectator's eye and, as it were, the celluloid. As recurring visual grammars in Colombian film, they illustrate an important shift away from the crude aesthetics of pornomisera films dealing with poverty or drug violence in marginalized urban settings that were so prevalent in prior decades. The term pornomiseria was coined by Cali filmmakers Luis Ospina and Carlos Mayolo in reference to films that feed on and exploit poverty and human suffering for international consumption. Their 1977 "mockumentary" Agarrando pueblo (titled The 


\section{Affective Visuality}

Vampires of Poverty in English) meta-filmically narrates how a film crew goes into the city's slums searching for gamins and vagabonds who are asked to take part in a film about their daily struggles. By laying bare the device and self-reflecting on a documentary about poverty-gazing that mocks those who engage in pornomiseria, the on-screen film crew (acted by Ospina and Mayolo themselves) ridicule European audiences (or more broadly, audiences in the North) who are avid to see first-hand the dire conditions in the slums and engage in a scopophilic gaze of the suffering of others. ${ }^{3}$

In an effort to move away from the fixation on "quasi-realistic" or mimetic depictions of violence in Colombia and the corresponding "misery porn" effect that captivate international audiences, contemporary film productions have explored alternative visual grammars that precisely avoid gruesome representations of violent acts and explicit naming of guerrillas, paramilitary groups, or drug traffickers. In these films, for the most part, we rarely see characters directly or explicitly struggling with gruesome violence, assassinations, or bloody crime scenes; rather, these characters (who often have suffered the dire consequences of the armed conflict) share their memories or lived experiences with the audience and build affective ties with them. By moving away from realist representations of the conflict, new Colombian cinema-seeking to explore the lens of national reconciliation-engage victims and victimizers in more egalitarian terms. In effect, these films disentangle simplistic and reductive views of good and evil (e.g., Victor Gaviria's La vendedora de rosas) that have long dominated representations of violence in Colombia as well as in national and international film markets.

\section{The New Cinema Law and the Colombian Filmscape}

To understand how the proliferation of these new affective and tactile visualities came into being in Colombian cinema, it is important to address how several convergent components lined up to materialize such a shift. First, the efforts to pacify the country and to dismantle armed groups were clearly designed to open up Colombia for global tradeparticularly when for years rural and remote areas had been off limits to national and international commerce. The beginning of the country's recent pacification process arguably started with the paramilitary demobilization (2003-2006) under President Álvaro Uribe, and culminated with the promulgation of the Victims and Land Restitution Law (Ley de Víctimas y Restitución de Tierras, Ley 1448) in 2011 and the peace process between the government and the FARC guerrillas (2012-2016) under President Juan Manuel Santos. ${ }^{4}$ With the advent of these pacification efforts, government-run tourism campaigns such as Colombia is Passion, Colombia: The Only Risk is You Wanting to Stay, or Colombia is Magical Realism proliferated in 2012-2013, signaling to the world new access to national territories long seen as warfare grounds. Widely 
available on TV outlets and media platforms, these infomercials were part of the government's branding effort to rid Colombia of its tarnished image as a perpetually violent country. In a series of promotional videos in Spanish and English, Colombia is showcased in a very different (and quite positive) light. This was accomplished through an ocular-centric display of exotic landscapes, diverse cultural and ethnic environments, cosmopolitan cultures, and harmonious living. ${ }^{5}$

Second, and concurrently with the government efforts to open up the country to the world, the 2003 cinema law (Ley 814) created a new taxation and fiscal system that boosted the production and distribution of films made in Colombia through Proimágenes — an institutional outfit in charge of collecting a percentage of each ticket sold in Colombian movie theaters and disbursing up to $40 \%$ in subsidized aid to film companies producing films in Colombia. ${ }^{6}$ And third, as a result of the pacification efforts and the new subsidy system, new film locations "opened up" in Colombia, particularly those territories that had been hard to reach and/or remained off the radar for film crews given the incessant armed conflict. These government efforts to create a "more secure" Colombia were designed to attract foreign investments and boost national productivity (particularly, in the service and tourist industries) favoring the expansion of the film industry due to its power to reach global audiences, and, obviously, potential consumers of Colombian cultural goods beyond national borders.

Specifically, the 2003 law provided a series of fiscal incentives for the production and promotion of films made in Colombia. Through this funding program, national film production has significantly increased, from 4-6 to about 35-40 films per year. ${ }^{7}$ The aims and objectives of Ley 814 and all of its related government directives and decrees for implementation signal the government's efforts to establish a global film industry in Colombia that caters to international co-productions:

Desde el 2003, con la expedición de la Ley 814 de 2003, Proimágenes administra el Fondo para el Desarrollo Cinematográfico (FDC), siguiendo los lineamientos del Consejo Nacional de las Artes y la Cultura en Cinematografía (CNACC). En este marco, recauda los recursos provenientes de un porcentaje de los ingresos de la industria y los ejecuta con transparencia y eficiencia, lidera el programa de internacionalización del cine colombiano, organiza las convocatorias públicas para la entrega de estímulos, coordina las actividades de acompañamiento y formación para los proyectos apoyados e impulsa a los futuros creadores [...] Asimismo, Proimágenes es el administrador del Fondo Fílmico Colombia (FFC), creado bajo la Ley 1556 de 2012, a través del cual se da una contraprestación del $40 \%$ del valor de los gastos realizados en el país por concepto de servicios cinematográficos y del $20 \%$ del valor de los gastos en hotelería, alimentación y transporte a las empresas que realicen las producciones en el territorio colombiano. 
Since 2003, under Law 814, Proimágenes administers the Film Development Fund following the guidelines of the National Council for Arts and Culture in Cinematography. Within this legal framework, it collects the resources coming from a percentage of the industry's income and executes its disbursement with transparency and efficiency; leads the internationalization program of Colombian cinema; organizes public calls for the delivery of film incentives; coordinates the accompaniment activities and training for supported projects; and encourages the promotion of future film creators [...] Likewise, Proimégenes administers the Colombia Film Fund, created under Law 1556 of 2012, which covers $40 \%$ of expenses incurred in the country for cinematographic services and $20 \%$ of expenses in hotels, food and transportation to companies that carry out productions in the Colombian territory.

(Proimágenes) (www.proimagenescolombia.com/secciones/ proimagenes/proimagenes.php)

In effect, Proimágenes centralizes all the funding efforts for production and promotion of Colombian cinema nationally and internationally "with transparency and efficiency" - a claim that is not fully shared by some of the filmmakers that Proimágenes seeks to promote. Be that as it may, for this enterprise to be successful a new mapping of Colombian cinema was necessary; that is to say, the films from the 1980s to the 1990s had mostly circulated among highly specialized audiences, and now Proimágenes (under the government's initiative to explore new avenues for commerce) sought to amplify their presence in international competitions like the Cannes Film Festival and the Academy Awards. In this regard, Juana Suárez argues in Sitios de contienda that the cinema law sought the flow of private capital into the film industry given the relative inefficiency of prior funding programs that were exclusively in government hands like the now defunct FOCINE (Compañía del Fomento Cinematográfico, 1978-1993) and that raised serious doubts about the viability of a national Colombian cinema on the part of producers and audiences alike (85).

But critics of the law claim that, while local filmmakers have greatly benefited from its funding and promotional initiatives abroad, many international production companies and technical support from abroad have, in effect, come to Colombia to take advantage of the financial incentives. In the end, the law has not really developed locally grown film production or the development of skilled film technicians. Several filmmakers have raised concerns about the "invasion" of international filmmakers in Colombia who are using the law's tax credits to produce their films at a fraction of what it would cost in other countries. ${ }^{8}$ Jorge Forero (the director of Violencia), for example, argues that the law was truly conceived as a "commerce law" that does not really address the needs of cultural components of filmmaking or those of local production companies in 
Colombian, since its primary goal is the expansion toward international markets. ${ }^{9}$ For sure, an important component in the new law is the promotion and distribution of films made in Colombia that generate "escenarios de retorno productivo entre los sectores integrantes de la industria de las imágenes" [scenarios of productive return among the sectors that make up the imaging industry] (Proimágenes), which clearly hints to international film festivals and other "scenarios" where Colombian films can be seen more widely-either through internet platforms and digital channels of distribution-and reach broader audiences.

Interestingly, while the law and government efforts sought to "sell a new Colombia" (more secure and pacified) through internationally recognized film productions, conflict and reconciliation continued to occupy a central role in the filmic narrative. This raises a series of questions about the perpetuation of "violent Colombian films" as a continued brand (albeit with a new filmic aesthetics favoring haptic and affective displays) in the global cultural market. To be sure, there has been an important shift in how conflict and violence are now being presented through affective visualities and haptic practices as new subjects who had been long ignored by mainstream cinema in Colombia are now part of the national filmscape. For instance, AfroColombians take center stage in Chocó (Jhonny Hendrix Hinestroza, 2014), La playa DC (Juan Andrés Arango, 2013), or Siembra (Ángela Osorio and Santiago Lozano, 2016); LGBTQI Colombians in Señorita María, la falda de la montaña (Rubén Mendoza, 2017); or indigenous communities such as the Guajira region's Wayuus in Ciro Guerra's Los viajes del viento (2009) and Pájaros de verano (2018; co-directed with Cristina Gallego). Clearly, these films depart quite significantly from the themes and aesthetics characteristic of pornomiseria as we now see how minority groups and their geographies are given a new voice. As a result, Colombian cinema enters into the transnational production system that fosters cultural diversity and ethnic pluralism as part of a global enterprise to tap into independent niche markets beyond mega film productions. For their part, and given the government-channeled funding, filmmakers are willing to "take more risks," and pursue filmic narratives that incorporate non-hegemonic discourses of the conflict (Martínez, Haunting 83-84).

For María Ospina, these new geographies are now being added to the Colombian filmscape as a direct result of the "rural turn" that took place after the 2003 law. This turn seeks to expand the "audiovisual mappings of rural spaces," and, in so doing, "offer alternative modes of mapping rural space and rural subjectivities in Colombia" while promoting a "global marketplace" in which "a peaceful land is ripe for leisurely travel, consumption, and investment" (Ospina, "Natural Plots" 248-251). Many of these films also contribute to the creation of spectacular landscapes that would correspond to a certain "postcardization" of the national territory and with a conventional way of presenting the typical topography 


\section{Affective Visuality}

of exotic places. But along with the inclusion of these rural topographies came an effort to explore and film violent scenarios attached to rural areas of conflict. The recent wide release of Alejandro Landes's Monos (2019) is a cogent example of the postcardization of rural enclaves where violent acts (e.g., kidnappings, murders carried by militarized children) take place in exotic and distant localities that are ripe for the development of extreme human depravity. Likewise, Ciro Guerra's most recent films offer audiences an intricate relationship between postcardization of remote areas (e.g., La Guajira) and crude violence, particularly shown in the astonishing visual display of violence and exoticized landscapes. But these landscapes are often shown (by filmmakers like Guerra, Vega, Acevedo, and Forero) through the haptic vision to account for the ambiguity, lack of resolution, and the continuance of conflict since land ownership still remains unresolved for many displaced people in Colombia who were forced out from their territories during the conflict. By displaying textured and granulated images on the screen, visual resolution remains somewhat opaque and unclear to the eye, raising doubts about their potential for historical closure.

\section{Affect and Mediation Reach the Cineplex}

Reading haptic visuality and tactility in contemporary Colombian cinema fits within the parameters of what Laura Marks calls "intercultural cinema" - a term that comprises other terms to refer to unconventional or non-commercial cinema, such as "third cinema" or "world cinema." It is in these alternative forms of filmmaking where an intercultural crossing occurs, not only between minorities and dominant groups but also between filmic narrative models of the "first cinema" and representations of the marginalities that are not typically present in commercial productions. The visual grammars in contemporary Colombian film productions are exemplary of an intercultural crossing and filmic narrative models often shown through the filmic deployment of materiality and tactility. Tactile images signal a new approach to the representations of conflict and its relationship with the film community that recent Colombian cinema proposes. Adding to this, the so-called "alternative forms" of filmmaking have now reached the Cineplex and are often shown along with major studio productions as part of a diversified film portfolio from which audiences choose; for instance, a blockbuster Hollywood film or, say, a Colombian film in Wayuu such as Ciro Guerra's Pájaros de verano, which had a wide release in the US, reaching many Cineplexes and arthouses throughout the country.

As Laura Podalsky reminds us, the turn to study affect is a direct consequence of the free market economy and our inability to synthesize the avalanche of data and information to which we are exposed (Politics 5). It comes from the imposition of "a new sensational cultural logic" that is based on promoting feelings of fear, uncertainty and insecurity, as well 
as generating an experience of daily life led by sensations (Politics 17). Thus, the turn to affect invites us to consider the affective alliances-or "affective practices" (4) according to Margaret Wetherell in Affect and Emotion - that arise from the community experience of film viewing. For Wetherell, affect is a "pre-eminently relational and social event" linked to the production of meaning shared by an "emotional community" (74), and therefore, it has political potential. What is being proposed in the affect-oriented approaches is to establish how we as viewers relate to what appears on the screen and how the affective and relational community dynamics inform the film viewing experience since, as Bruno reminds us, "film moves, and fundamentally, moves us, with its ability to render affects, and, in turn, to affect" (7). ${ }^{10}$

I would like to argue that such dynamics are key for our understanding of the cinema of conflict and reconciliation in Colombia since these films establish relationships of affect between viewers and film subjects. Furthermore, it is often the case that affect is thematically incorporated into the storyline in these films to illustrate how affective relations through touch and contact bring about reconciliation, as we will see in the analysis of La sombra del caminante, La tierra y la sombra, and Violencia. Indeed, what we see on screen in these films seems to be in closer proximity with the audience, and, as it were, touches us through a multisensorial experience that defies traditional cinema viewing, in which the spectator "passively" visualizes and consumes what is on the screen (as is the case in most major Hollywood productions). ${ }^{11}$

In "The Affect Turn," Podalsky further situates the turn toward affect in Latin America within the context of state-sponsored terrorism and civil wars of the late 20th century. She argues for a need to understand "how cultural production interpellates their audience on a sensorial level" (251) beyond analyzing how emotions are represented in particular texts. I propose to analyze recent Colombian cinema within this "turn to affect" that has led to rethinking the communal affective relationships imbued in it, particularly when it comes to conflict and reconciliation through the multi-sensorial experience afforded by haptic vision. In the case of Latin America, affect has raised some suspicion among scholars due to its linkage to capitalist tactics (Podalsky, "Affect" 241). ${ }^{12}$ As Nilo Couret reminds us in "El movimiento de cuerpos," many Latin Americanists precisely condemn the celebratory rhetoric of affect-oriented interpretations as there is a level of suspicion about affect being manipulative and therefore any emotional manifestation is marginalized or simply excluded from the political sphere:

Esta suspicacia suele suponer que una política afectiva es necesariamente manipuladora; más aún supone que cualquier cambio político conlleva la reformación de los mecanismos estatales y que la lucha política es una lucha territorial de posición. 


\section{Affective Visuality}

This suspicion usually presupposes that an affective policy is necessarily manipulative; furthermore, it assumes that any political change entails the reforms of state mechanisms and that political struggle is a territorial struggle for positionality.

In the specific case of Colombia, affective practices (while suspect for some) have long been present in the various governmental and grassroots attempts at pacifying and reaching national reconciliation. It is not entirely a question of emotion over reason to end the 50-year armed conflict; rather, it is about how these affective practices are constructed and deployed in the context of "post-conflict" Colombia. Colombian films of the last decade signaled that-even before the peace accords were signed and ratified - national reconciliation had reached the Cineplex, as audiences in Colombia were having access to new ways of seeing the conflict through film viewing and accessibility to national film productions. These new film productions proliferated and, in turn, produced a high level of commodification of the reconciliation process by which the latter has become another cultural consumption good already integrated in the free market of the neoliberal economy-the same neoliberal economy that, for Podalsky, has produced a surplus of affect in cultural production. This begs the question if affect must be commodified as an effective tool to achieve the political insertion of victims and offenders in the reconciliation processes, which takes us back to the purported suspicion about manipulation in affect-oriented approaches in Latin American studies.

Drawing on affect theory and addressing the fundamental question of how to represent the Colombian conflict, Rubén Yepes proposes the term "mediation" to study affective practices in cultural production. In Afectando el conflicto (2018), Yepes argues that what we see in artworks by Doris Salcedo and films by Ciro Guerra or César Acevedo are not merely representations of the conflict but, rather, mediations. These cultural productions aim to mediate an affective link between urban audiences and the localized rural areas where the conflict has typically taken place. Yepes's approach favors the term mediation over representation since the former implies the audience's active participation and relational processes characteristic of emotional communities. The emphasis, therefore, is on "the social process in its totality" (43) and not just on the content of the cultural object. ${ }^{14}$ In the specific case of Colombian cinema, he argues that films such as La sombra del caminante or La tierra y la sombra "mediate conflict through a complex and variable inter-relation of visual elements, symbolism, and affect expressed through bodies in action" (61). For Yepes, these films move away from the made-for-TV film style of prior Colombian film productions while defying spectacular violence as a source of entertainment. It is through haptic visuality that these newer films draw spectators toward the image erasing the distance 
between our position as spectators and the subjects and surfaces presented on the screen:

lo más interesante de la imagen cinematográfica sucede no a nivel de la narrativa, el significado o el discurso, sino a través de los efectos inmediatos de la imagen sobre el cuerpo del espectador.

the most interesting thing about the cinematographic image happens not at the level of the narrative, the meaning or the discourse, but through the immediate effects of the image on the viewer's body.

My argument, however, has a slightly different take as I see the haptic image in unison with the filmic narrative, which is not only informed by the visual but actually defined by it. With this in mind, next I examine affect and haptic visuality in three exemplary films-La sombra de caminante, La tierra y la sombra, and Violencia-that were produced between 2004 and 2015, after the advent of the cinema law and legislation leading up to the peace process in Colombia (2012-2016). These films break away from the visual hegemony that has traditionally narrated the conflict in Colombia and/or exploited crude and explicit violence for mass consumption. These new filmmakers offer a more nuanced take on conflict and resolution through complex visual grammars that require active viewers to communally engage in looking at the national past and present. It is important to remember that while these films were made before the actual signing of the Peace Accords in 2016, they actively promote reconciliation through affective practices.

Now, if visual tactility and haptic perception encourage a communal film viewing experience and active spectators to perform it, what happens then with the limited circulation of the new Colombian cinema within the national territory as opposed to Hollywood mega-productions? What effect can these newer films have on the reconciliation processes in Colombia? While academics, film scholars, and those interested in intercultural cinema want to be participants in communal film viewing and in discerning its ambiguity and complexity, a large majority of Colombian audiences completely obviate these films and prefer the optical visualites offered in commercial films available at the Cineplexincidentally, the same Cineplex where national films like the ones studied in this chapter are being shown. It is precisely at the Cineplex of shopping malls-exemplary locations of the neoliberal and global market economy that recent Colombian governments have so avidly promoted as a sign of peace and prosperity in the country-where Colombian cinema and its own national spectators are first exposed to these tactile visualities and the affective practices leading toward national reconciliation. For its part, the international film market writ large has embraced these new visual grammars that are now being deployed by Colombian filmmakers 


\section{Affective Visuality}

and that can be fully incorporated into alternative forms of film viewing. Furthermore, these films have entered into digital platforms that have expanded viewership of Colombian cinema and allowed global audiences to partake in new ways of seeing conflict and reconciliation in Colombia. ${ }^{15}$

\section{Approaching the Other in Ciro Guerra's La sombra del caminante}

La sombra del caminante is a unique film that addresses reconciliation through affective practices and tactile visuality like no other contemporary Colombian film had done before. The film offers a novel entry point into conflict and resolution through its emphasis on affective relationships and communal viewing. It is, in many aspects, a precursor to the "new ways" of seeing the conflict and its potential resolution for Colombian film audiences as it lays the groundwork for alternative visual grammars to appear in the last two decades of Colombian cinema. ${ }^{16}$ Shot in black and white, the film approaches the Colombian conflict by looking into the lives of two outcasts who coincidentally had been a victim and a victimizer years before in a rural site in Caquetá. Now they are both desplazados (displaced persons) in Bogotá, and often seek each other's company to deal with the daily struggles of being unemployed in the city.

Both characters partake in the so-called economia del rebusque; that is, the underground economy of street sellers and day laborers doing odd jobs (which is part and parcel of the neoliberal economy already discussed). Mañe is a disabled war veteran who lost a leg in the armed conflict and, risking eviction from his home, must resort to selling origami figures in the streets to make a living. Mansalva, a pseudonym for a mysterious character whose background and provenance are not completely known, works as a silletero giving rides to people on a chair strapped to his back for a few hundred pesos. ${ }^{17}$ The two protagonists meet by chance when Mansalva rescues Mañe from the street thugs who beat him and steal his wooden leg. After this fortuitous encounter, they both partake in precarious living conditions exposed by their rebusque and engage in a series of personal exchanges that foment their relationship and complicity. For instance, Mansalva carves out a replacement wooden leg for Mañe and protects him from those who attempt to harm him; in turn, Mañe teaches Mansalva how to read and write and secures a city permit for Mansalva to continue his job as a silletero thanks to his army and police connections.

As the two outcasts become closer and the background story about the armed conflict and their reasons for displacement unfolds, confrontation begins to build up. Toward the end of the film, we learn that Mansalva participated in the massacre of innocent civilians in Caquetá, where he was shot in the head. Mansalva suffers from a permanent brain injury that can only be alleviated with a mysterious medicinal plant provided to him by an unidentified indigenous tribe. Through a series of coincidences 
in the filmic narrative the two protagonists soon realize how intricate their past truly is. One day Mansalva finds out that the army sergeant who took part in the military offensive in Caquetá against his armed group happens to be Mañe's landlord and next-door neighbor. Afraid of being recognized, Mansalva disappears from Mañe's life. In the hopes of reestablishing their lost companionship, Mañe decides to steal the medicinal plant Mansalva uses to ease the pain from his brain injury. Soon thereafter, Manslava takes up Mañe's offer to look for the plant, but the street thugs who often harass the limping Mañe have stolen it. Unable to apply the herbal remedy, Mansalva's health begins to deteriorate: having a bullet in his head ultimately results in a fatal brain hemorrhage that ends his life. ${ }^{18}$

In the film, spectators are placed in the main characters' positions to view how conflict and reconciliation unfold before their eyes following the interactions between two displaced characters confronting a similar precarious existence. Seeing and not seeing are key elements in the film, which, of course, relate to not seeing the conflict through explicit violence and gory details of warfare but rather through the characters' own partial viewing and through witnesses of the armed conflict. For instance, this is visually displayed through Mansalva's eyes. His gaze is impeded throughout the film due to his dark glasses and black umbrella that prevent his eyes from having direct sun and light exposure. Similarly, spectators cannot always fully grasp what is being displayed on the screen and are often kept in the dark.

The importance of seeing and not seeing the conflict becomes evident when in a pivotal moment toward the end of the film, Mansalva shows Mañe a video in which a crying woman details the atrocities that an unidentified armed group committed in Caquetá. Her testimony makes it evident that the two protagonists had been at different receiving ends of such atrocities many years before. Up to this point Mañe-and the audience-had been kept in the dark about Mansalva's past crimes, but aware of the conflict's impact in Mañe's life. In an earlier scene that sets reconciliation in motion, both characters walk alongside niches in Bogotá's cemetery where Mañe reveals that his parents were gruesomely killed ("guttered and hanged") in Caquetá but it remains unclear who actually did it: "First, they told us it was the guerrillas, then the paramilitary, then narcos, then rogue military" (48:00; cited from the English subtitles). This earlier scene takes place in broad daylight, out in the open air, for anyone to clearly see except for Mansalva, whose gaze is partially impeded by his dark glasses. Things get darker quickly (visually and thematically).

As we approach a resolution about who was behind the massacre in Caquetá, the deployment of tactile and haptic visualities (and much darker images) occupies the screen. Rubén Yepes reminds us that the impact on the public at large has been a determinant factor for the visibility (or invisibility, as the case may be) of the conflict, and such impact 


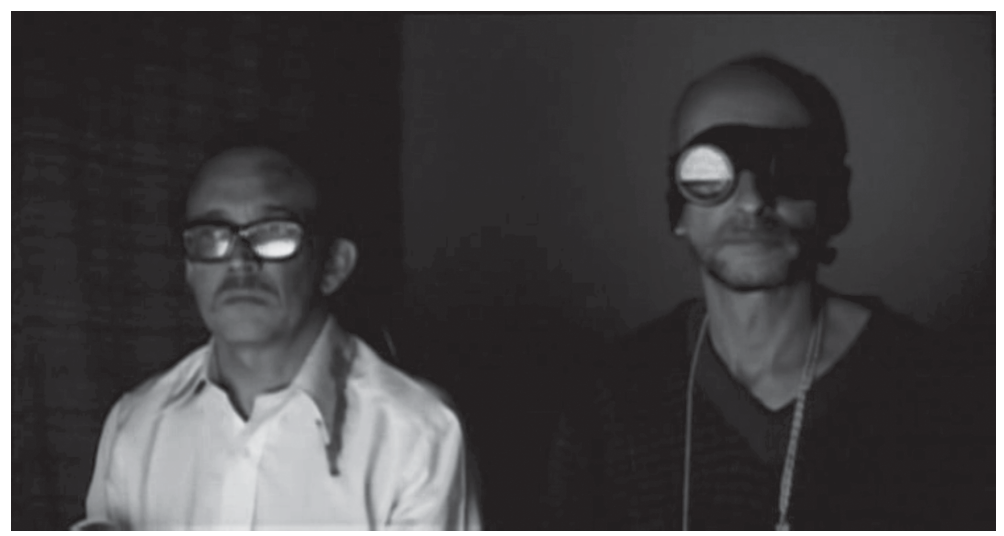

Figure 4.7 Mañe and Manslava in La sombra del caminante (screenshot). Courtesy of Ciudad Lunar.

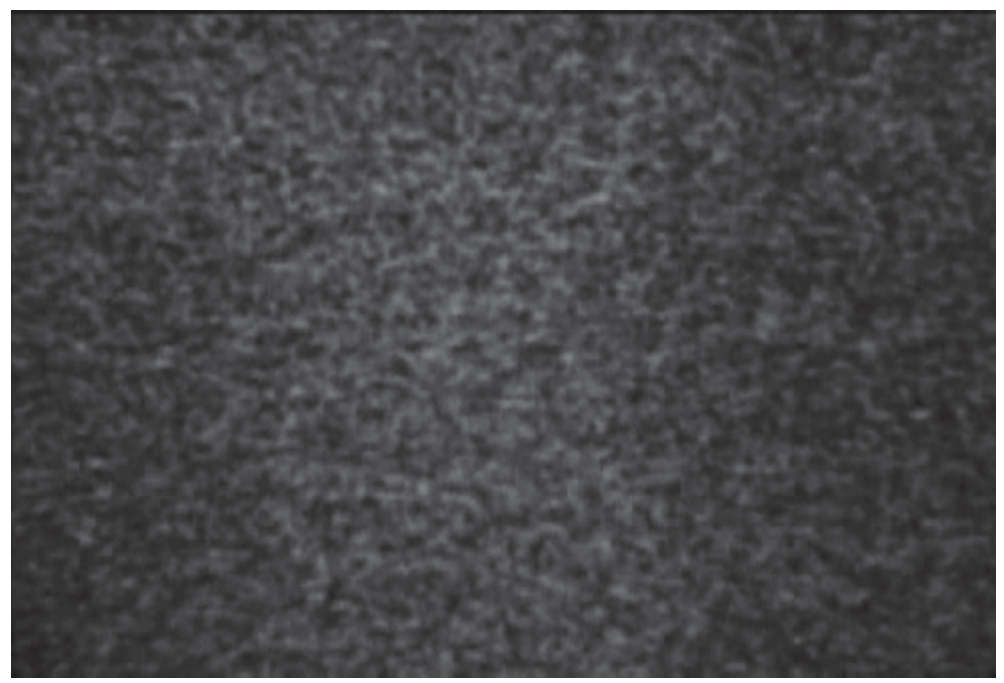

Figure 4.8 TV static in La sombra del caminante (screenshot). Courtesy of Ciudad Lunar.

is attributed "according to hegemonic power" and "public influence" (39). The two protagonists become "invisible" and lack any influence on the public at large due to their precarious living conditions as desplazados.

These two screenshots (Figures 4.7 and 4.8) encapsulate the key moment in which victim and victimizer sit down together in the dark to learn the truth about Mansalva and his responsibility in the death of Mañe's family and leg injury—all due to a hospital bombing carried 
out by Mansalva's armed group. It is a first attempt at reconciliation in which we as spectators are drawn by these images and the didacticism of this metafilmic moment. The film subjects and viewers experience a similar interaction with the moving image as they share their proximity with the so-called skin of the film, with the granulation and grayscale on display. If we pay close attention to the first screenshot (Figure 4.7), the atrocities Mansalva committed are minimally reflected on Mañe's clear glasses and are partially obscured in Mansalva's dark glasses. The emphasis here is precisely on not showing the gruesome details of the crimes committed in Caquetá (something that would have been more akin to the parameters of pornomiseria filmmaking) but rather on showing the memories and testimonials of those present at the crime scene. Since the video does not explicitly display any images of the atrocities, many questions remain unanswered and the full picture of what really happened remains incomplete in a gray zone. After the woman's testimonial gets cut off and the video turns to static, Mañe demands an immediate explanation from Mansalva: "You did ... all that. Why are you showing me this? Answer me!" (1:08:00). The granulation of the static takes over the entire screen: a four-second closeup of the granulated image is followed by Mansalva's sudden collapse to the floor in the dark room, as Mañe and spectators share the blurriness surrounding Mansalva's role in the events in Caquetá. In the static's grayscale Mañe remains in the dark and Mansalva's involvement in the massacre in Caquetá continues to be unresolved.

Thus, in watching the testimonial video, film subjects and spectators are invited to communally read through the visual static and granulation on display - an indication that the past and conflict remain murky and irresolute. ${ }^{19}$ The massacre in the past still needs to be sorted out through the film subjects, and the spectators actively engage in deciphering the granulation and grayscaling that the haptic viewing experience entails and that will ultimately bring truth and the final reconciliation. In a sense, this scene shows us how to see the conflict and engage with its potential resolution by reaching out "the other" (that is, by touching "the other" and being touched in return). As Brian Massumi reminds us, "when you affect something, you are at the same time opening yourself up to being affected in turn, and in a slightly different way than you might have been the moment before" (4).

Light and dark contrasts dominate the video watching scene as haptic perception is foregrounded in key moments of the filmic narrative. This visual effect is further underscored by the contrast between Mañe's white shirt and Mansalva's black T-shirt and glasses as identifiers for the victim and victimizer, respectively. But, as we see, these markers of good (white) and evil (black) become undone and thrown into question through our exposure to haptic perception and tactile visuality in the film. Identifying the victim and the victimizer gets harder to discern and becomes a more complex ethical and visual exercise. As Martínez reminds us, haptic 
perception is not a matter of seizing the image or controlling it: rather, "haptic perception marks a dissonance between sight and mastery; it suggests more than what it explains; it digresses and wanders around it; it is emotionally charged and points toward the unresolved" (Haunting 92).

This is precisely how the story about the armed conflict in La sombra del caminante is told through a series of digressions and wanderings that expose the conflict's untenable resolution. Following Mansalva's collapse, hospitalization and subsequent escape to his tent in the mountains surrounding the city, the protagonists finally reconcile their past actions and talk about forgiveness. Mañe discloses that he stole the medicinal plant to regain Mansalva's companionship and bring him back into his life; and Mansalva, for his part, comes clean about all his past killings and his involvement in the massacre that affected Mañe's family. Mansalva's final confession reveals that he himself was (one more) victim of the armed conflict. He was recruited as a child and trained to kill on behalf of his armed group, and in that sense, he too has been a victim of the spiralling conflict in Colombia:

MANSALVA: Are you willing to listen?

MAÑE: Yes.

MANSALVA: I have killed many people ... elderly, children, pregnant women ... When you get used to killing, you do it without thinking, without feeling. And after all that death, there is nothing left. You can't understand me. Do you know what it's like to be taken, from home to the hills, when you ain't even got hair on your face? Do you know what it is like to be one day carrying people from side to side of the river, and the next in the middle of the jungle learning how to kill? You don't know.

$[\ldots]$

MAÑE: Do you think I will forgive you?

MANSALVA: No forgiveness. There is no forgiveness for us.

(1:13:00-1:19:00; cited from the English subtitles)

Haptic perception envelops this final dialogue in the film as the reconciliation between the two protagonists remains inconclusive since there is no forgiveness for them. Visual effects bookend the film's final dialogue between victim and victimizer. As Manslava is about to confess his crimes and his involvement in killing Mañe's family, he removes his dark glasses for the first time in the film as he faces the blasting sun on his face. It is a moment of truth and reconciliation marked by an alternation of darkness and brightness that complements the prior use of light and dark in the video watching scene. Likewise, a close-up shot of Mansalva's ear slowly dripping out blood (a sign of the fatal brain hemorrhage) marks the spewing of his atrocities and the loss of hearing (and understanding) between victim and victimizer. In an act of humanity toward his companion of rebusque, Mañe buries Mansalva in the hills overlooking the 
city, touchingly placing one of his hand-made origami figures atop the burial site. The film's open-endedness (there is no forgiveness, no closure) is summarized in the final close-up of a portrait of Mansalva with his dark glasses and chair strapped to his back drawn by a street artist. The silletero remains an intriguing figure in the social imaginary of Bogotá, a sort of urban legend urban legend whose provenance (except for Mañe) will remain a mystery for city dwellers. For his part, Mañe is bound to remain "invisible" as a victim of the conflict, as one more desplazado trying to make ends meet through the economy of rebusque.

\section{Seeing Through Ash in César Acevedo's La tierra y la sombra}

La tierra y la sombra is a slow-paced and reflective film in which there is no explicit or implicit reference to the armed conflict or war actors in Colombia (e.g., guerillas, paramilitaries, army, narco-traffickers). Its opening scene sets the tone for the haptic experience proposed by the film to address conflict and reconciliation beyond the pornomisera patterns of warfare and urban dereliction..$^{20}$ Instead, the film's focus is on personal and familial reconciliation amidst day laborers' struggles in the sugarcane fields of the Cauca Valley region. Conflict and reconciliation are, however, constantly present in the film as family and labor relations are seen literally through the ash and dust impregnating the breathing spaces in the characters' lives due to the constant brush fires that have taken over agricultural production in the region. Spectators likewise experience a similar sense of suffocation while viewing this film (and may feel compelled to cough and clear their throats while watching it) as incessant ash and dust become recurring textures splattered on the screen day and night. The textured images produced by ash often occlude our vision and underscore our inability to grasp a full view of the conflict and potential resolution. This can be "seen" (or, rather, barely seen) in dark interiors in the family home whose windows and shutters are closed to prevent the ashes from entering the house or in the exterior images that are clouded by ash and dust (Figures 4.9 and 4.10).

The movie begins with Alfonso's return to the family home, after years of being estranged from his wife Alicia, to care for their convalescent son Gerardo-a sugar cane laborer who suffers from an incurable respiratory illness aggravated by constant brush fires that pollute the air. The return of the father is framed within a cloud of ashen dust along a pathway in a rural enclave. As Alfonso slowly progresses toward the camera, his body is completely enveloped in a dust from the road and disappears before our eyes. He is the absent figure returning to a home now besieged by the brush fires, an ominous sign of the impending death of his son. Flanked by sugarcane fields, the dusty road leading to the family home situates the agricultural exploitation in the filmic narrative that limits the characters' actions (at times, they can't quite breathe and see), and, in turn, limits the spectators' visual perception. Ash and dust (as far as we can surmise in 


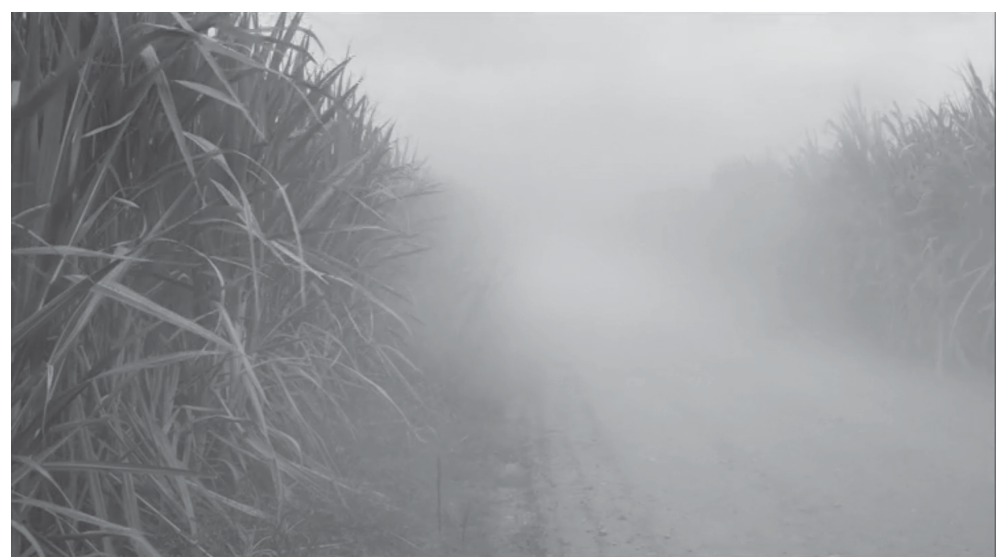

Figure 4.9 Dusty road in La tierra y la sombra (screenshot). Burning Blue Films.

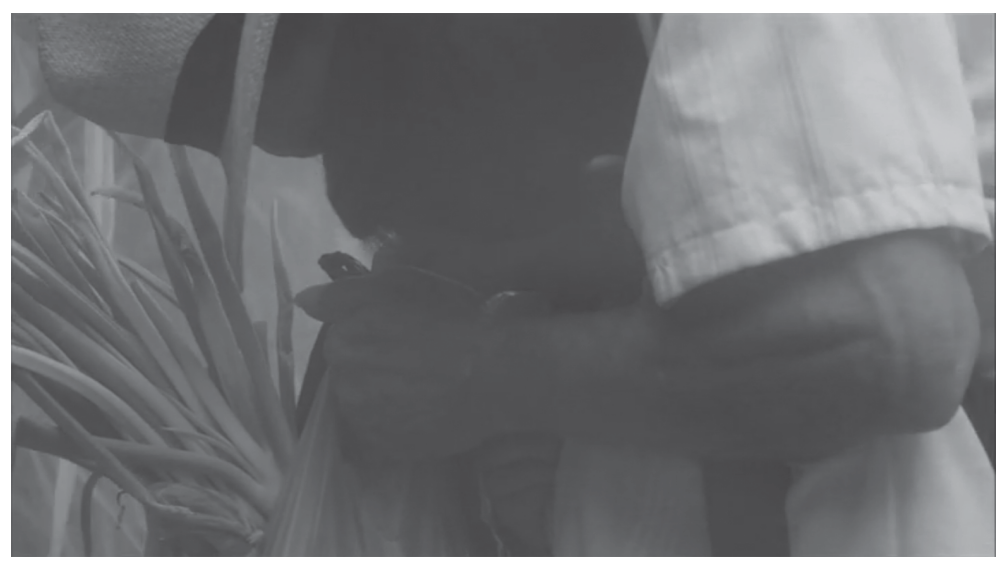

Figure 4.10 Alfonso and Manuel covered in ashen dust in La tierra y la sombra (screenshot). Burning Blue Films.

Figure 4.9) demarcate the land and the lives that inhabit it. This is underscored when, later in the film, Alfonso protects his grandson Manuel at exactly the same place in the road we see in the opening scene. This reiterates the film's emphasis on haptic visuality while reproducing an affiliation between the different generations of the family-grandfather and grandson are wrapped in a protective hug to fight the toxic ashen dust that has so tragically affected Gerardo's health. Undoubtedly, the repercussions of sugarcane exploitation in the region can be felt across family generations.

The conflation of dust, smoke and ash with the return of Alfonso activates the two central conflicts in the film. There is a personal conflict 
(Alfonso, who abandoned his wife Alicia and his family for another woman, returns to attend a family crisis at home), and there is a social conflict that frames the first one-the exploitation of sugarcane workers in the Cauca Valley and its consequences for the family's subsistence and the environment. Neither of these two conflicts ends in a clear reconciliation agreed between the parties: Alfonso, after Gerardo's death, will ask Alicia for forgiveness but there is no audible response from her. Instead, touch and proximity take center stage as the estranged Alicia and her husband engage in a tepid embrace shortly after Gerardo's final breaths. It is just a brief moment in which "opposing parties" timidly reach out with a rather distant hug. Earlier in the movie, Alicia declares that she cannot forgive Alfredo for abandoning the family home and sets the rules for a minimal interaction between the two while Gerardo is convalescing. On the family front, reconciliation does not really materialize as years of personal conflict remain irresolute.

Similarly, the "other" conflict in the movie, dealing with the sugar cane day laborers and their employer, cannot be resolved. The model of agricultural exploitation in the region follows a colonial rule, in which powerful landowners control the economic subsistence and dictate how to conduct the agribusiness within the patterns of a transnational neoliberalism. Monoculture is now being undertaken by international corporations seeking to make a more profitable use of the land-even if this means destroying family's livelihoods and the environment. As an example, despite Alicia's and Esperanza's (Gerardo's wife) efforts to work as day laborers to cover ailing Gerardo's shift, their employers decide to fire them for not being able to keep up with the pace of production mandated by the demands of agricultural production. Their fellow day laborers, in an act of solidarity with the two women, pitch in to help achieve the quota of sugar cane cutting required by the owners. In the end, day laborers continue to cut and burn the sugarcane fields despite the dire economic and health conditions set by the landowners.

The two conflict zones laid out in the filmic narrative-the home and the sugarcane fields-come together in one as the ashes from the incessant burning penetrate the air and sip through every corner of the family house. Suffering from an acute respiratory illness, Gerardo's breathing (and overall health) deteriorates quickly, as ashes invade the house and the family space becomes darker and more enclosed to prevent further damage to Gerardo's lungs. Ashen dust besieges the house and its immediate surroundings. Manuel reminds Alfonso that the house windows should not be opened to keep ash from coming in. Detailed shots of plants, the outside patio, and the sky all covered in ash enhance the characters' feeling of enclosure and suffocation. Images of the burning sugarcane are interspersed in the film with scenes about the conflict between day laborers and landowners, particularly about their pay and their precarious working conditions. For Martínez, the future of rural lands occupies an important role in the cinematic narrative of recent Colombian films as 


\section{Affective Visuality}

the new territories now being filmed expose "the complex and often violent nature of interventions in rural communities [...] by armed groups, stage agents, agro-industrial and tourism entrepreneurs, and film crews alike"-which is often done by foregrounding smooth spaces on the screen that highlight socio-economic tensions through the haptic vision's "oblique gaze" (Haunting 90). In this regard, the film offers long scenes that foreground these smooth spaces where nothing really happens to advance the plot, the tempo comes to a standstill, and viewers are left to contemplate the omnipresence of ash, dust, and smoke in the characters' natural habitat.

These spaces are sites for conflict. As the labor conflict escalates, so does the lack of visual fullness inside the family home, which remains in permanent penumbra or darkness. Visual fullness of the home is never complete as the threat of smoke and ash coming from the outside occludes the home interior and keeps it in the shadows. The light outside the house contrasts with the darkness inside the house, but even in the film's exteriors, the presence of dust, ash, and smoke ultimately impedes full vision. This visual effect reinforces the idea that the film viewer ultimately has to draw the missing lines to complete the image, to seek the resolution of the plot, and to give possible closure to the unresolved conflicts in the film. It is through a multiple sensorial activation of seeing and touching that audiences may reach proximity to the family conflict and the broader sense of national conflict. For example, the camera details Gerardo's dead body being touched and slowly and carefully cleaned of ashes, or the fixed objects of the house that are presented as a still life; that is to say, a moment fixed in time and space, as if it were already a place of memory not completely alien to what one finds in areas ravaged by conflict (Figures 4.11 and 4.12).

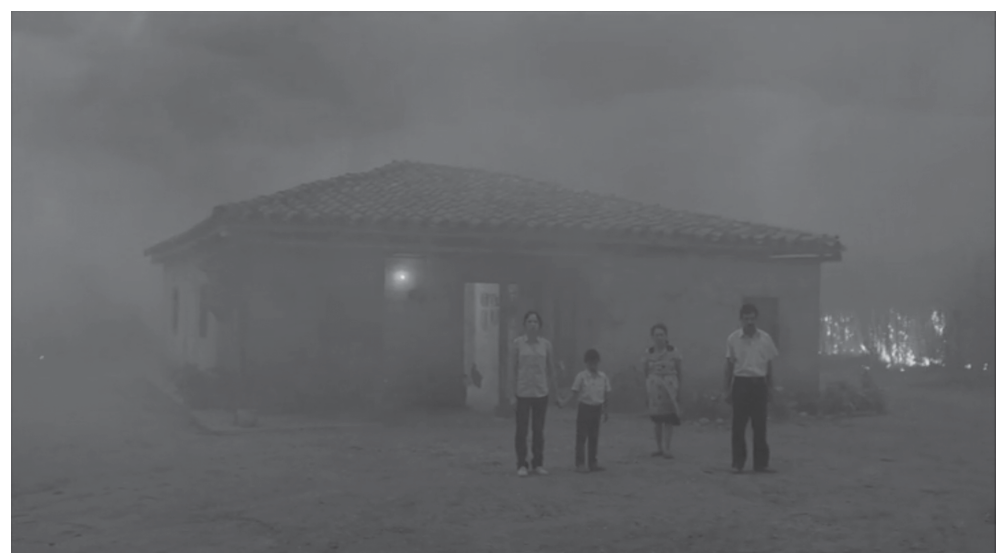

Figure 4.11 Family house surrounded by fire in La tierra y la sombra (screenshot). Burning Blue Films. 


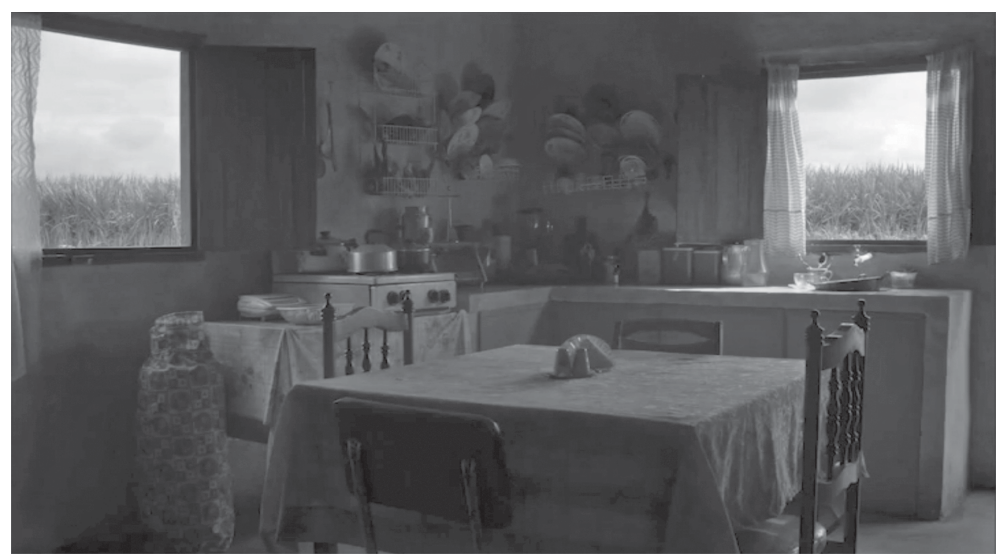

Figure 4.12 The empty house in La tierra y la sombra (screenshot). Burning Blue Films.

This visual grammar of La tierra y la sombra is constructed through occlusion. As Laura Marks points out, "the ideal relationship between the viewer and the image in the haptic visuality is mutual, in which the viewer is possibly lost in the image, loses his sense of proportion" while in the optical visuality there is a tendency to establish a master relationship "in which the viewer isolates and absorbs the objects of vision" (184). This dichotomous distinction is not so easy to discern in Acevedo's film, especially if we take into account that his technical achievement resides precisely in a combination of these two modes of visuality, which, as Marks herself states, are not always so diaphanously distinguishable. These haptic images illustrate what Marks calls "a cinema marked by a suspicion of visuality, a lack of faith in the ability of the visual archive to represent cultural memory" (21). Undoubtedly, this idea is extrapolated in one of the most impressive images of the film reproduced above (Figure 4.11). Once Gerardo has died, the whole family remains motionless, anesthetized, and contemplative before the fire that surrounds the house and the smoke that envelopes their existence. This infernal image has been used for the film's poster and for DVD covers since it encapsulates the visual grammar proposed by Acevedo to tackle life struggles in rural areas of Colombia that are no longer the location for the armed conflict but that are not devoid of conflict.

In this sense, La tierra y la sombra recasts the role of the rural landscape as a new scenario to examine the Colombian conflict. For Ospina, this rural turn-which includes films such as Los viajes del viento, $\mathrm{La}$ sirga, or Chocó-centers the discussion into the complex and problematic relationship between the nation and its natural borders (the Pacific region, the Amazon, rural areas in the Caribbean, the plains, etc.). These 


\section{Affective Visuality}

are often seen as geographical margins of the national center and places of exploitation of resources that must be channeled within the nation (something that is clearly seen with agricultural exploitation in La tierra $y$ la sombra). Interestingly, the exploitation of the sugar cane which the film criticizes also operates as a catalyst for its visual construction-the inordinate closeup shots of sugar cane stocks and ash from the brush fires trigger the film's tactile visuality and its intentional rebuke of neoliberal policies for the local agribusiness. All this makes us think about topography and geography as well as cinematic and economic resources, but as well about issues of production, circulation, and distribution that sell specific Colombian geographies in the international market.

Furthermore, Acevedo's film addresses another important issue that resonates well with international film audiences interested in advocacy and social awareness: the impact of extractivist practices in Latin America and their ecological and environmental threat for local communities. In "Post-Conflict Visual Ecologies," Camilo Malagón explores how La tierra y la sombra explicitly connects the exploitation of the land through monoculture with the exploitation of human bodies suffering the consequences of ecological mismanagement by local government and international agribusiness companies. Drawing on Rob Nixon's "slow violence" (a systemic conceptualization of violence referring to the gradual and cumulative deterioration of land, water, and air) and ecocriticism, Malagón sees in La tierra y la sombra an exemplary case of visual ecology within the so-called rural turn in Colombian cinema. ${ }^{21}$ Indeed, inequalities in land ownership and accessibility to farmland have long been at the crux of conflict in Colombia, and the characters in Acevedo's film are clearly situated at the receiving end of such inequalities. The incessant brush fires, smoke, and ashen rain visually remind us that there is a looming ecological crisis in rural communities that depend on agriculture and a clean environment for their subsistence. The characters in La tierra $y$ la sombra suffered the consequences of an adverse economy that relies exclusively on monoculture exploitation of their natural habitat, which the textured images and haptic vision of the film bring to the fore.

\section{Aural Visuality in Jorge Forero's Violencia}

In October 2016, just one month before the final ratification of Colombia's Peace Accords between the government and the FARC guerrilla, the daily El Espectador commemorated the event with the free-access streaming of Jorge Forero's Violencia through the newspaper's website. Up to that point, Forero's film-produced in Colombia under the auspices of the 2003 cinema law-had only circulated nationally in limited release and had not been accessible to most international audiences, despite prior efforts to promote the film's opening through social media and video platforms. A Colombian film titled "violence" is an intriguing and bold proposition since it immediately brings to mind Alejandro Obregón's 
1962 well-known painting La Violencia. In this iconic oil on canvas (and related studios), Obregón portrays a naked woman on her back that appears to have been disfigured and killed in a rural area (Chico 129142). As she lays inert, her body meshes with the rural landscape through dark and gray tones splattered with dashes of red color near her damaged breasts. While Obregón's work-an exemplary case study for abstraction and the aesthetics of partial viewing in tune with haptic perception-is not referenced in Forero's film (or in any of the existing literature about it), it is important to think about these two creative instances as seeking to encapsulate Colombia's violences through textured images and haptic perception.

Aside from emulating Obregón, using the title "Violencia" suggests that violence (in its multiple modalities) in Colombia can be actually encapsulated in one artwork or film. To this end, Forero proposes to provide audiences with a triptych of three independent but visually related stories about the armed conflict, each taking place during a 24-hour period in the lives of victims and victimizers. This is visually anticipated in the movie poster, which shows the word "violencia" split in three syllables ("vio-len-cia") in superimposed lettering that foreshadows the narrative triptych and the textured visuality in the film. Furthermore, the poster's background lists an inordinate number of kidnapped victims including their date of liberation, of their humanitarian release or exchange, or their killing, as the case may be. This list, which is almost imperceptible to the naked eye (another instance of hapticity prior to the actual film viewing), provides the historical context for the three storylines in the film. These three instances in Colombia's daily life-as blurry as the poster would seem to anticipate-can be taken as exemplary case studies of how the normalcy of violence has taken root in the country to the point that the most mundane activities are irremediably tied to the armed conflict (Figure 4.13).

The film tells the stories of three unidentified individuals who partake in the Colombian conflict: a kidnapped victim in the jungle struggling for survival in precarious physical condition; the execution of a falso positivo or victim of an extrajudicial killing carried out by the Colombian army to shore up their number of reported casualties of armed guerrillas; and a paramilitary leader in charge of a training camp for assassins whose life seems "normal" during the better part of the day. While the film aims to cover a large swath of the conflict in Colombia, it is a relatively short film that does not truly develop each story. Instead, it offers a minimalistic depiction of perpetrators and victims in specific sites and modalities of conflict. The film's focus is clearly on the multi-sensorial effect on the audiences as it moves away from the crude or explicit exposition present in pornomiseria films. The textured images and aural visuality-aural understood as sonic or "as relating to the ear or to the sense of hearing" (Webster's Dictionary)—are key elements in the three stories, but more so in the first one (the captive in the jungle), which occupies my analysis. 


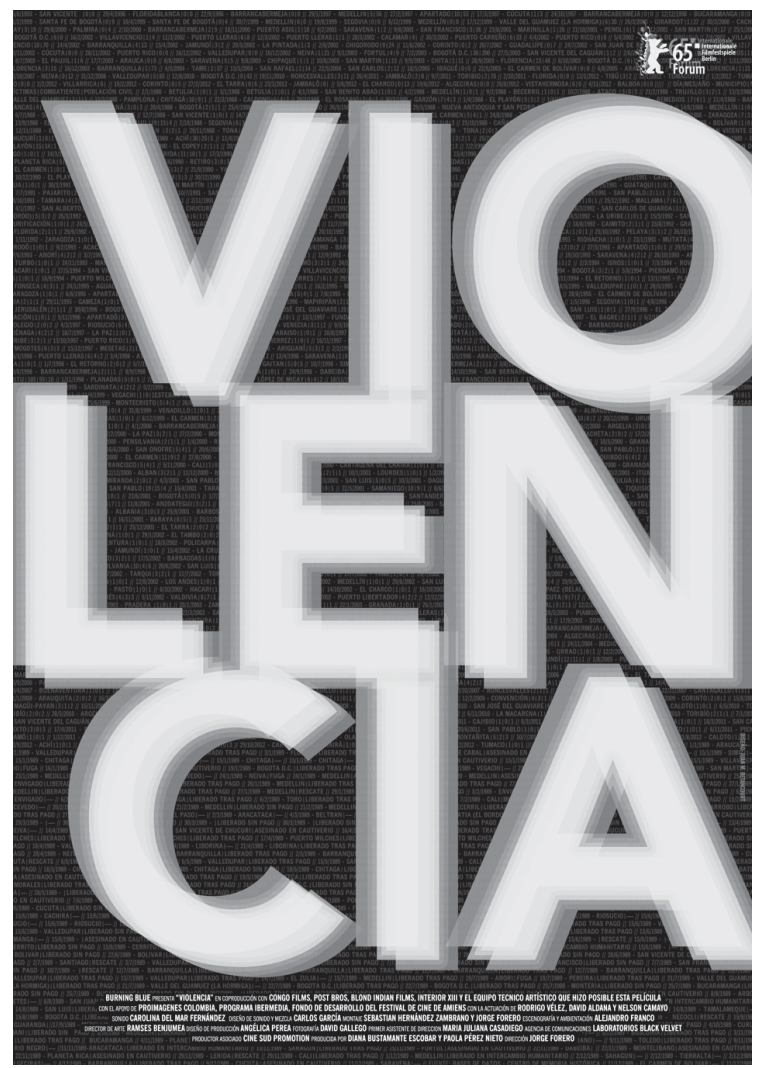

Figure 4.13 Movie poster for Jorge Forero's Violencia. Courtesy of Jorge Forero.

During the first three minutes of Violencia, viewers see a completely black screen and hear a series of sounds coming from what appears to be the jungle. As film viewers remain expectant for clarity on the screen, we are kept in complete darkness. We engage in a sensorial experience that unites the blackness on the screen with the aural input of birds chirping and crackling sounds of lush jungle vegetation. In this manner, Violencia opens up with a communal aural experience that leaves the filmic narrative open to the viewer's imagination (at least for a few minutes). As suggested by Bruno, "the haptic experience, in geographic terms, involves knowledge of surface, geometry, material, location, energy, and dynamics" (254). Through the film's haptic experience, we sense, touch (as it were) the geographical contours of the jungle through sound and get to inhabit it in the dark. By placing the optical visuality on hold, the film highlights the importance of sound, the knowledge that comes from it, and what it may evoke in audiences who are particularly cognizant of the various forms of violence known to have taken place in Colombia. A film that 
opens up with such a scene is clearly suggestive of the many kidnappings that have occurred during the armed conflict and have ended in jungle captivity-the most notable case being Ingrid Betancourt (discussed in Chapter 2).

When the black screen fades out by the fourth minute into the film, the jungle begins to appear in a series of blurry closeups showing a man laying inertly on the ground and meshing with it (a suggestive recreation of Obregón's tableau). Daylight "clarity" reveals that this man is chained and being held captive by an unidentified armed group in a remote area of the jungle. We have no information about the captive, his captors, or the circumstances that led to his captivity. There is no dialogue and no communication between the captive and his captors; we simply hear the loud jungle sounds, the water from the river, and the footsteps on the ground and across the lush vegetation against the undecipherable murmurs of soldiers. The sensorial effect we experience is that of being transported to the jungle (in unison with the captive) through what Martínez identifies as an alternate sonority: "a type of sound of management that makes little or no use of dialogue and relies almost entirely on environmental sounds and subtle cues [...] to advance and create emotional engagement with the story and its protagonists" (Haunting 91). This is precisely the point the film wants to make: we need to hear and see the conflict in a different manner, feel the conflict differently. We need not know the specifics behind the chained man's life and the circumstances of his captivity; instead, the film invites audiences to sensorially experience his daily struggles, his walking in a hostile terrain through aural visuality. As spectators listen to birds, crickets, crackling sounds coming from the branches and foliage, the lack of clarity continues. What is being displayed on the screen is blurry, undetermined; it is an unidentified space in terms of the visual display but clearly identifiable through the environmental soundscape.

As day breaks and the captive is moved to another location in the jungle, he is allowed to bathe in the river while being watched by one of his captors. Halfway through the movie's first segment, there is still no dialogue or verbal interaction between the captive and his captors. The muddy river waters take over the filmic narrative and provide the captive a respite in his captivity. He is allowed to linger in the water and submerge his head in the river, and as the captive's head slowly submerges into the water, our partial viewing is enacted and we slowly see how his head appears and disappears in the cloudy river waters. Finally, the brownish color of the river takes over the entire screen and we are left to imagine ourselves holding our breath underwater. The screenshots below show this progression from seeing the captive's head barely above water to its total submersion and possible drowning. Similar to what we experience with ash in La tierra y la sombra, viewers are here also confronted with suffocation as the captive's head submerges longer and longer into the water and does not surface. The camera then holds steady underwater 


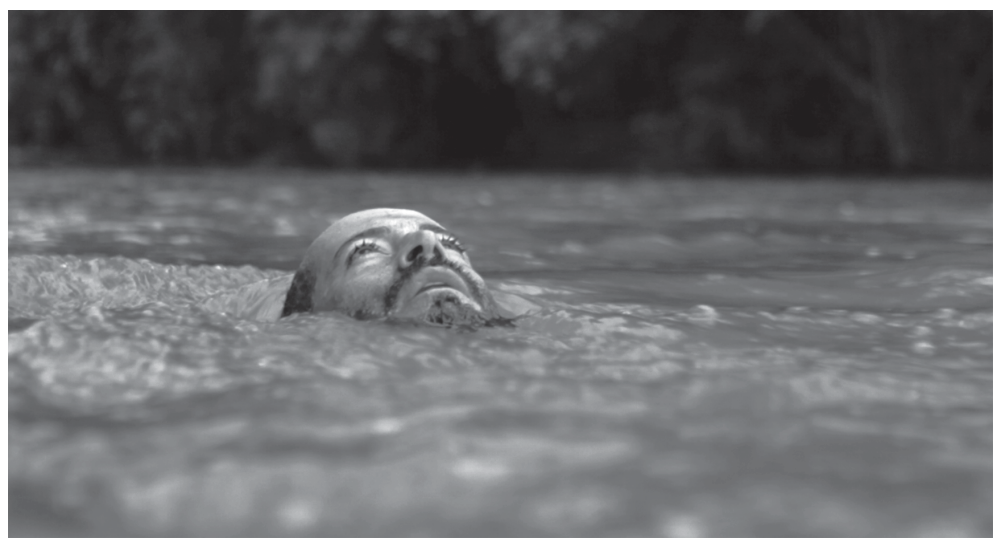

Figure 4.14 Unidentified captive bathing in the river in Violencia (screenshot). Courtesy of Jorge Forero.

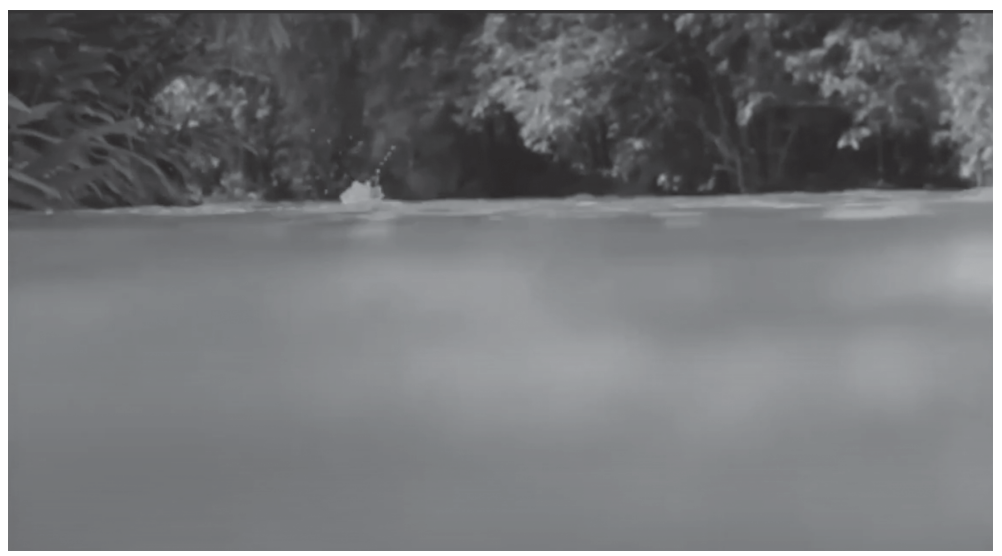

Figure 4.15 Unidentified captive fully submerged in the river in Violencia (screenshot). Courtesy of Jorge Forero.

and the river waters take over the visual and sonic components. We see the river waters rising on the screen up to the point when they completely occupy it, resulting in a shot in which viewers only see a brown screen filmed from the river bottom and hear no sound or breathing from the victim (Figures 4.14 and 4.15).

These textured images offer an alternative modality for the representation of the Colombian conflict. By virtue of the haptic perception, viewers partake in a multi-sensorial experience in which the filmic narrative does not primarily lie in verbal dialogue and background information about the story. Instead, conflict is constructed as a series of interrelated sounds 
and partial viewing of the hostile terrain that engulfs the protagonist and our full access to visuality. When we see the camera slowly descending into the bottom of the river, the image turns muddier and the captive's underwater breathing becomes muted. This aural visuality triggers an association between captivity (enclosure) and freedom (the river as an open space) on the viewer's part, and amplifies our film viewing experience through sound.

The final segment in the captive's story moves quickly from the brown river waters to nighttime in the jungle. This way we circle back to the beginning of the film as darkness takes over the screen again, and the haptic perception continues to dominate our viewing experience. We barely see what is being displayed on the screen, but we can surmise that the captive, curled up in a hammock, is feeling unwell. The jungle sounds remain in the background but are slowly muffled by the captive's incessant grunting and guttural noises. He falls from the hammock onto the muddy ground in agony with a bout of diarrhea as his grunting continues to be heard. A respite from his misery comes when a guerrilla soldier comes to his rescue, carefully lifts him from the ground, and helps him go back to the hammock. It is a rare instance where we see (albeit in almost complete darkness) a touching moment between the perpetrators and their victim, and contributes further to the multi-sensorial experience upon which the captive's story is filmed.

Full darkness closes off the film's first segment and invites viewers to partake in the victim's sense of agony and pain. As Whetherell suggests, "flows of affect can mesh, for example, with [...] the imaginaries streaming through darkened cinemas" (12). In the final minutes, once the captive is back on his hammock, he listens to Las voces del secuestro-a radio program in which family members send caring messages to kidnapped victims..$^{22}$ As he (apparently) hears a family member, he begins to cry and the screen turns completely black. We go back to the full darkness that opens the film, but this time the jungle sounds are replaced by the captive's sobbing and crying. Audiences experience a completely dark screen again, having to rely on sound to tie the loose ends in an otherwise inclusive story about the victim and his victimizers. In all, the film's opening story is to be heard and seen through the filmic soundscape. It is indeed a case for aural visuality within the multi-sensorial patterns characteristic of haptic perception, which tells us about a kidnapping victim in a very different light (pun intended), without dialogue, confrontation, resolution, or historical grounding.

Through the visual textures displayed on the screen, Violencia and films like La sombra del caminante or La tierra y la sombra dismantle the optic-centric traditional visuality that most viewers are accustomed to, and in effect, force viewers to practice and engage in an alternative gaze of the moving image. This alternative gaze encourages the audience to see conflict and reconciliation through the haptic perception and engage 


\section{Affective Visuality}

in active film watching. As Jennifer Baker reminds us in The Tactile Eye, textures are to be considered as "something we and the film engage in mutually, rather than something presented by the films to their passive and anonymous viewers" (25). Thus, spectators are asked to be part of a film community that has to unravel the erasure of the dominant optical visuality in conventional cinema. The tactile and sensory sensations fostered by haptic visuality promote emotional communities through touch: "the kinds of touch that occur between film and viewer shape, inflect, even infuse the meanings of films and the nature of the relationship we have with them" (26). We are asked to explore ways of nonhegemonic seeing or gazing, and, in so doing, we need to rethink the other sensory components-in addition to sight and sound-that are part and parcel of the film viewing experience.

These new ways of seeing (at least, new for Colombian cinema) must be understood in terms of a communal viewing that ultimately relates to a shared experience in knowledge about how conflict in Colombia has been represented through film. As we share our interpretations and film viewing experiences with others who have likewise experienced the haptic visuality in these films, we become more active toward film spectatorship and, as it were, more proficient in new visual grammars that seek to dismantle the hegemony of spectacular and optic-centric views. Thus, film viewing occupies itself with the dismantling of what Laura Marks calls "the relative weakness of the visual image" (153) as these films look for active spectators who get lost in the image and embrace the mutuality implicit in haptic visuality. This calls for touching the filmic surface with the eye as we move away from the illusionist depth that is typical in optical visuality, which is considered an ocular-centric form of knowledge often associated with capitalism, hegemony, and power: "the skin is a meeting place for exchange and traversal because it connects the inside with the outside, the self with the other" (28). It is precisely in the meeting of skins (the film's and the viewer's) that the film narrative becomes meaningful. And, in the case of recent Colombian cinema, audiences are asked to participate in a communal filmic experience informed by touch and contact with the other, and with the victims and victimizers of the decades-long armed conflict.

\section{Notes}

1 According to Bruno, "as a function of the skin, the haptic-the sense of touch-constitutes the reciprocal contact between us and the environment, both housing and extending communicative interface" (6). Her conceptualization of the moving image within "the field screen" is understood as a "habitable geographic space” (250).

2 In Haunting Without Ghosts, Martínez further argues that recent Colombian films "are hard to watch, not because they show graphic or explicit images but because one could almost say that they too often fail to 'show' anything at all” 
(77). Instead, these films propose a new visual grammar for Colombian cinema based on the multi-sensorial approach perception typical of haptic perception, which underscores the "nonvisual capabilities" (e.g., tactile) of the eye: "sound, texture, and emotion are all key parts of the haptic perception" (91-92). In these new films, narrative dialogue, visual clarity, and resolution are relegated by the preponderance of silences and background sound, visual occlusion, ambiguity, and open-endedness. It is also important to note that not all recent Colombian films or filmmakers share the haptic imprint described above.

3 For contextual and background information about this film genre, see Faguet ("Pornomiseria," 2009). A case in point of pornomiseria are Víctor Gaviria's films, which often show an expository and (somewhat) exploitative representations of Colombia's "darker side," as can be seen in Rodrigo D: no futuro (1990) or La vendedora de rosas (1998). Gaviria's most recent film La mujer del animal (2016) returns to gruesome depictions of violence, in this case, against women in the Colombian slums. The difference with his prior films being that the protagonist's over-the-top monstrosity and maltreatment of women throw the film's purported realism into question.

4 The Victims and Land Restitution Law sought to provide judicial assistance and reparations for victims of the conflict from 1985 onward "as a result of grave violations of International Humanitarian Law and of international Human Rights norms" (Ley 1448; my translation). www.centrodememoriahistorica. gov.co/micrositios/caminosParaLaMemoria/descargables/ley1448.pdf). Despite the government's efforts to seek restitution to the victims' families, there have been many logistical and budgetary problems to enact this law as illustrated in the documentary Un asunto de tierras (2015) by Patricia Ayala Ruiz.

5 For sample videos, see the following YouTube links: www.youtube.com/ watch?v=Hn4hMEOpF8o; www.youtube.com/watch?v=F8y4gBz4bR0; www. youtube.com/watch?v=AJ-MKNnlzi4.

6 In her essay "Nuevo cine colombiano," Minerva Campos argues that what is "new" in Colombian cinema has to do with the efforts made by Proimágenes since 2003 to promote the international distribution of filmmakers such as Óscar Ruiz Navia (El vuelco del cangrejo, 2009; Los hongos, 2014), Carlos César Arbeláez (Los colores de la montaña, 2011), Carlos Moreno (Todos tus muertos, 2011), Rubén Mendoza (La sociedad del semáforo, 2010), William Vega (La sirga, 2012), Juan Andrés Arango (La Playa DC, 2012), César Augusto Acevedo (La tierra y la sombra, 2015), and Ciro Guerra (La sombra del caminante, 2004; Los viajes del viento, 2009; El abrazo de la serpiente, 2015): "son estos realizadores y las películas citadas las que los festivales internacionales han celebrado en torno a la idea de un Nuevo Cine en el país" [It is these filmmakers and the films mentioned that international festivals have celebrated around the idea of a New Cinema in the country] (123; my translation). Martínez argues that the cinema law, despite its shortcomings, "created a viable and more independent alternative to an industrial model that requires massive private or state capital, allowing filmmakers to take more risks" (Haunting 284). Thus, these filmmakers have broken away from the more established (or mainstream) narratives in favor of visually rich, engaging films with broader appeal for global audiences and international circulation. 


\section{Affective Visuality}

7 Carolina Rocha points out that a significant portion of new Colombian films are actually co-productions with European and Latin American countries $(40 \%)$, and about $37 \%$ of films have the support of Ibermedia, which was established in 1997 to boost cooperation for filmmaking among IberoAmerican countries ("Cine colombiano en el siglo XXI" 124). The Spanish government, according to Tamara Falicov, currently contributes about $60 \%$ of the funding while the other signatories (Argentina, Bolivia, Brazil, Chile, Colombia, Costa Rica, Ecuador, Mexico, Panama, Peru, Portugal, Puerto Rico, Dominican Republic, Uruguay, and Venezuela) contribute proportionally the remaining $40 \%$, which is often adjusted due to individual countries' financial needs ("Programa Ibermedia" 22: https://cinema.usc. edu/assets/054/10911.pdf). For more information on Ibermedia, see www. programaibermedia.com/.

8 See "Lo malo de la ley de cine"; www.youtube.com/watch?v=NBO3g 81FIfg.

9 See "La ley del cine en Colombia"; www.youtube.com/watch?v=x_j5s1Jy1NM.

10 Similarly, Brian Massumi sees this biunivocal movement in affective practices: "To affect and to be affected is to open to the world, to be active in it and to be patient for its return activity" (Massumi, loc 159). See also Brinkema.

11 Melissa Gregg and Gregory Siegworth point out that "affect is born as "inbetweenness' and resides as accumulative besides-ness [...]; affect marks a body's belonging to a world of encounters" (2). Such encounters are important for the affective practices that may lead to "touching the other" in the context of reconciliation.

12 Affect-oriented approaches were relatively new in Latin American studies until the publication of scholarly works such as Podalsky's The Politics of Affect and Emotion in Contemporary Latin American Cinema (2011), Geoffrey Kantaris and Rory O'Bryen's Latin American Popular Culture: Politics, Media, Affect (2013), Dierdra Reber's Coming to Our Senses (2016), or Mabel Moraña and Ignacio Sánchez Prado's El lenguaje de las emociones: afecto y cultura en América Latina (2012). With a few exceptions, most affect-oriented scholarly studies have not explored the specificity of Colombian cultural production. For instance, Felipe Gómez Gutiérrez in "Filmar en desacuerdo" examines affect in Luis Ospina's documentary filmmaking within the historical context of the Peace Accords in Colombia.

13 For more on the political ramifications of affect, see Brian Massumi's seminal work The Politics of Affect. He argues that "the concept of affect is politically oriented from the get-go [...] affect is pro-political" (loc 152). In the Latin American context, Beasly-Murray sees affect as "an index of power that can never be entirely contained" (cited in Podalsky, "Affect" 244). For Yepes, there is a "destabilizing dimension in affect" that entails both "a promise and a threat," which relates to an ambiguous political position in affective practices (55-56).

14 Yepes thinks of these works as "open objects," as part of a process that opens up the expectations "between sites, subjects, and heterogenous social sectors," in which the viewer has to actively engage in an inter-relational process with the artwork or film (46-48). This is important to consider when analyzing films that require an "active engagement" on the part of viewers. 
15 It is worth noting that La sirga was first released online to whet the appetite of international moviegoers through a massive internet dissemination that led to its wide release after several film festival showings. Likewise, the daily El Espectador streamed Jorge Forero's Violencia on the newspaper's website to commemorate the signing of the Peace Accords in 2016. These efforts to promote communal viewing for Colombian films at home and abroad have contributed to amplify the marketing of Colombian cinema beyond its national and linguistic environs toward a much wider release as we can see in the case of Monos, El abrazo de la serpiente, or Pájaros de verano-all of which are international co-productions benefiting from the new cinema law.

16 The financing for this film falls within the patterns of independent filmmaking. It was self-funded by the director's own production company Ciudad Lunar, in part, thanks to the money received from Ciro Guerra's participation in a TV game show. The film benefited from the 2003 law's promotion efforts for Colombian cinema, and it was widely shown in national and international film festivals earning the Premio en Construcción award at the San Sebastian Film Festival. It was also selected as Colombia's entry for the 2006 Academy Awards, but was not chosen by the Academy: (www.proimagenescolombia. com//secciones/cine_colombiano/peliculas_colombianas/pelicula_plantilla. php?id_pelicula=274).

17 María Ospina argues that the film captures the neoliberal model of a city that thinks of its citizens as consumers. The opening scene is a series of closeups that precisely illustrate the precarious economy in which the characters live. We see how Mansalva is sawing a coffin and recycling its wood to build his chair ("Evocar y convocar" 170-176). For her part, Juana Suárez argues that while this is still a film about violence in Colombia, the approach is very different since commonplaces are avoided, and it is not a commercial film in the way it handles poverty despite the camera being displaced to the margins of the city (89).

18 Ospina interprets the herbal remedy as a variation of yagé (a hallucinogenic plant) within the patterns of indigenous magical knowledge and aura (as Michael Taussig argues in Shamanism) and as an example of the marginal territories that are now incorporated in Colombian films ("Evocar" 176-177).

19 Yepes points out that films like La sombra del caminante "do not advance toward resolution"; rather, they are conceived as "segments in time" that seem "to have been cut out from a temporal continuum that encompass them" (345). In my view, the film's intent is to keep the conflict purposely irresolute and to afford audiences to tie the loose ends.

20 La tierra y la sombra won the Camera d'or Award at the Cannes Film Festival and was subsequently widely distributed in France on DVD and through digital platforms. Financed transnationally and co-produced between Colombia, Spain, The Netherlands, France, Chile, and Brazil, it is an exemplary case of the return to rural locations for film production facilitated by the 2003 cinema law. It is entirely filmed in El Tiple, a village in the municipality of Candelaria (Valle del Cauca) known for its ingenios azucareros or sugarcane mills. 


\section{Affective Visuality}

21 Drawing on Susan Sontag's On Photography, Rubén Yepes advocates for an ecology of images from the Colombian conflict in order to address the potential apathy toward the victims due to overexposure. Circulation and conservation are needed to protect their testimonial and affective values (Yepes 187-188).

22 Forero's film shows two sample messages that would typically be heard during the program Las voces del secuestro (directed by Herbin Hoyos; see Chapter 2, note 19). For an analysis of this radio program in relation to emotion and hope (i.e., affect), see Stephen Leonard's "Voices from the Outside” (2019). 


\section{Epilogue \\ Post-Conflict Colombia?}

Cartagena, September 26, 2016. This date and location marked an important milestone in the five-decade long and arduous journey toward peace in Colombia. It was, indeed, a festive and sunny day that almost seemed made-to-order for the nation and the world to see. Under beautiful skies, Cartagena became the site for a harmonious display of national unity and reverie that was reminiscent of Nam Le's descriptions of this Caribbean city discussed in this book. National and international leaders gave inspiring speeches about peace, Colombia's future and diversity, and the need for reconciliation. Everyone present was wearing perfectly ironed and immaculate-clean white guayaberas for the momentous occasion: the signing of the Peace Accords by President Juan Manuel Santos and the FARC leader, Timochenko (nom de guerre for Rodrigo Londoño Echeverri). After the deal was signed, Santos and Timochenko shook hands and tapped each other on the shoulder, and, as a symbolic gesture of peace, Santos pulled out a lapel pin in the shape of a white dove that Timochenko clumsily managed to put on his guayabera. An air show ensued, and planes colored the sky with the yellow, red, and blue colors of the Colombian flag to which white was added as an emblem of peace. It all signaled the culmination of four years of complex negotiations in Havana, Cuba, and, ultimately, the cessation of hostilities and laying down the arms. Televised globally, the event had all the makings ofyet another-carefully crafted and choreographed media event intended to tell the world that peace was finally coming to Colombia, that international commerce was now welcome under better security conditions, and that the nation should embrace the peace deal and ratify it in a national referendum on October 2, 2016.

This branding and marketing of peace as a media spectacle is anchored in neoliberal policies that are entrenched in Colombia. It is clearly designed to neutralize insurgency movements that could potentially suppress global commerce and economic growth-the tenets of neoliberalism. As Alexander Fattal argues in Guerrilla Marketing, the Colombian government is no stranger to marketing and branding techniques, as shown when its Ministry of Defense deployed marketing strategies to "sell" humanitarian interventions to FARC ex-combatants with a view

DOI: $10.4324 / 9781003195702-6$ 


\section{Epilogue}

to ending counterinsurgency through consumer culture, signaling the emergence of marketing as "central strategy of antiguerrilla warfare in Colombia," and the birth of "the postconflict" (xii; see also "Branding the Postconflict State," 215-220). This "post-conflict" state was precisely on display both at the signing ceremony in Cartagena and at the related musical festivals- "FARC in the Park" or "FARC Woodstock" (Fattal 229) —in guerilla campsites that followed the signing ceremony.

But all these efforts to "sell" peace, to "sell" the moment of peace, before an ample political spectrum cracked in the weeks to come. Due to years of mistrust and anger toward the guerrillas, voices of dissent began to throw the Peace Accords into question. Thus, the moniker "post-conflict Colombia" quickly turned from being stated to being questioned. Soon, the opposition to the accords from the right and a certain level of complacency about participation in the referendum from the left derailed, in effect, the ratification vote. To be certain, the final result was a squeaker victory for those against the peace deal by a difference of 55,000 votes out of approximately 13 million cast-that is just a meager $0.44 \%$ separating "no" and "yes" voters, according to data from the National Civil Registry ("Histórico," Registraduría Nacional). The result threw the peace process into disarray (at least, temporarily) and left many unanswered questions about Colombia's immediate future and long-term plans for peace and national reconciliation. It moved the needle from "post-conflict Colombia" to "post-conflict Colombia?" as the Peace Accords appeared to be in tatters.

Given the political and economic support that the peace deal had garnered internationally, many wondered what went wrong after the celebrations in Cartagena and FARC campsites. Two film documentariesNatalia Orozco's El silencio de los fusiles (2017) and Margarita Martínez's La negociación (2018)—posit that the major stumbling block during the peace negotiations was the transitional justice system-a special judicial route for actors of the conflict. For opponents of the deal, this transitional justice meant "full amnesty" for guerrilla combatants and the State's "cleansing" of blood crimes, particularly against civilian populations. As Martínez and Orozco show us in their films, it was the active involvement of the upper echelons of the Colombia military what finally brokered the deal and made the accords acceptable to all negotiating parties. But the agreement had to be sold to the general public, and, as powerful as marketing and branding techniques can be, it was a tough sell.

I, for one, was struck by the government's effort to put the cart before the horse-namely, organizing a celebratory signing ceremony with international leaders a few weeks before the ratification vote at the polls; and, for another, I was surprised by the wording on the referendum ballot, which posed a somewhat unrealistic and chimeric question to the voters: “ ¿Apoya usted el acuerdo final para la terminación del conflicto y la construcción de una paz estable y duradera?” [Do you support the final accord to end the conflict and to construct a stable and long-lasting 
peace?] (Lafuente; Registraduría Nacional). Who wouldn't say yes to ending the conflict and securing a durable and stable peace? But, more importantly, who was to believe that a durable and stable peace could, in fact, be achieved in Colombia given the nation's history of violence? Evidently, a slim majority of voters did not see the viability of peace in the terms proposed by the accords. And the reasons for this are clearly anchored in a deep distrust for government-led interventions of this kind, particularly when issues like land restitution and transitional justice were not completely clear (in terms of their implementation) to a large swath of the electorate. The idealistic and harmonious fashion in which the Peace Accords were presented and cast in the media, ultimately, backfired. Many voters resisted the State's negotiations with leftwing guerrilla members who had committed atrocities against civilian populations, and the "special" justice system put in place for them. In all fairness, the right wing of the Colombian political spectrum also received special judicial treatment during the demilitarization of former Autodefensas Unidas de Colombia (AUC) combatants. Under the 2005 law, promulgated by President Álvaro Uribe (who led the campaign efforts against the peace deal), members of the AUC willing to lay down their arms received what amounted to amnesty from the government, despite the many documented atrocities they had committed between 1997 and 2006 ("Justicia transicional”).

To shore up support for the peace deal, the nation's leading newspaper El Tiempo (which President Santos's family owned between 1913 and 2007) ran a series of banners on its web homepage titled "the numbers we would leave behind"-which assumed, of course, the referendum would favor the Peace Accords. These banners were quite visible and occupied about one third of the newspaper's homepage and, at the top of the page, the "final countdown to peace" was on display: "total time of the armed conflict: 52 years, 4 months, and 5 days." Likewise, the banners provided readers with crucial information that would certainly make anyone think twice before rejecting the peace deal, as the staggering numbers "to be left behind" suggested: "8,190,451 crime victims between 1985 and 2015"; "11,269 legal cases for crimes committed by FARC guerrilla members"; "1,234 days without any town being taken by force during the current peace process"; "14,458 victims of landmines between 1990 and 2016"; " 11,556 child soldiers recruited by the FARC between 1975 and 2014"; "52 years of warfare with the FARC"; "6,000,000 people displaced due to violence"; "1,642,394 victims of homicide and forced displacement"; and "250 guerilla combatants have been convicted for crimes against humanity" (El Tiempo, October 2, 2020). The newspaper's effort, though, proved to be insufficient to get the ratification process via referendum over the line. And, in many ways, it probably had the opposite intended effect, as it underscored for proponents of the "no" vote the gravity of guerrilla warfare crimes and the injustices that it created for millions of Colombians. 
The rejection of the Peace Accords at the polls meant that a revised version of the document would have to be drafted and ratified by all parties. It became clear that transitional justice, land restitution, and security concerns for former combatants were major sticking points in any effort to find a viable pathway toward sustainable peace in Colombia. ${ }^{1}$ The general terms for the revised peace deal were negotiated by former President Uribe (who led the "no" campaign) and President Santos. After a month of political wrangling, and consultation with Colombia's Supreme Court, it was agreed that Congress would hold the final ratification vote. And so it happened. On November 24, 2016, the government and the FARC signed the revised accords, which were ratified by Congress a few days later, and another signing ceremony (this time, much more subdued than the one in Cartagena) took place at Bogota's Teatro Colón: the "Acuerdo Final para la Terminación del Conflicto y la Construcción de una Paz Estable y Duradera" [Final Accord for the Cessation of Conflict and the Construction of a Stable and Durable Peace]—-that's the official titlebecame the law of the land. But conflict has continued and the number of assassinated social leaders has increased nationwide since 2016-more than 1,000-, which indicates that peace is still elusive and certainly not stable.

The upsurge of armed groups from the right and left political spectrum, such as Autodefensas Gaitanistas de Colombia (AGC) and Movimiento Revolucionario del Pueblo (MPR), illustrates the point that durable and stable peace is still a long way away and that the possibility of a "postconflict Colombia" remains in question. For instance, on June 17, 2019, the MPR bombed Bogotá's upscale mall Centro Andino, killing three women and injuring nine other people; there has been an uptake on illicit activities of Gaitanistas in the drug trade and civil assassinations (Vargas, "Autodefensas"), and on August 29, 2020, FARC leader Iván Marquez decried the Peace Accords and pursued the rearmament of dissident guerrilla factions. Furthermore, negotiations with Colombia's "other" guerrilla, the ELN (Ejército de Liberación Nacional), remain stagnant, as the current government led by President Iván Duque has slowed the implementation of the peace process to appease his political base, who generally supported the "no" vote in the referendum. Adding to this, the COVID-19 pandemic has amplified the stagnation of political negotiations, and the peace process remains at a standstill for now.

These roadblocks notwithstanding, the final ratification of the Peace Accords is a watershed moment for Colombia, and, as such, has shifted the focus from violent warfare and displacement (with the noted exceptions) toward "post-conflict" reconciliation, peace, and violence. Cultural production soon followed this important shift in the political landscape and in public debates toward an emerging "new" Colombia. If prior decades gave us expert violentólogos [violentologists] to explain and-often pontificate-about the origins and intricacies of violence in Colombia, now it appears to be the turn for posconflictólogos or posacuerdólogos 
[post-conflictologists or post-accordologists] to take center stage. Books, articles, seminars, conferences, opinion pieces, debates, and so forth have flooded the cultural and academic fields to address the repercussions of the peace deal on a wide range of subjects: tourism (Rueda Esteban), justice (Mira Olano), indigenous communities and minorities (Osorio Calvo), gender (Lemay), human rights and labor practices (Ochoa-Cubillos), land restitution (Restrepo Salazar), violence in the Andean borderlands (Idler), economic conditions and finance (Zuleta), extractivism and mining (Valencia Aguelado; Ulloa), cultural patrimony (Guerra Molina), and environmental sustainability (Arias; Lugo), to name a few.

Given the many facets and complex realities involved in the peace process, Castillejo-Cuéllar has argued for the term "peace on a small scale" to include certain local communities that are otherwise excluded from discussions about the Peace Accords. The importance of intersectionalities in studies of peace and reconciliation processes, as Castillejo-Cuéllar suggests, should be thought from small scale within local contexts and from the notion of a "peace in plural." Therefore, it is imperative to open the field of Colombian studies toward a broad and interdisciplinary discussion, which would bring liminality-understood as the quality of ambiguity or disorientation that occurs in the middle stage of a rite of passage-and daily life as key components of Colombia's political transition (Castillejo-Cuéllar, "La paz" 6-7). But, following the frequent and recent deaths of social leaders (not to mention the country's turmoil and social unrest as a result of the government's new taxation plan), it is hard to find closure to the conflict. Peace-be that in the plural or the singular-is still far from materializing in Colombia.

Be that as it may, the aforementioned expansion of "post-conflict" studies also underscores the country's geographical opening up. As a result of guerrilla warfare cessation, there has been new access to remote areas and territories that would have been otherwise marked off as danger zones during the conflict. The cultural landscape, too, partakes in these changes brought forth by "post-conflict" (or, more appropriately, "post-accord Colombia")—a process that began in earnest in 2012 and continues to this day. Cultural commodification, as discussed in this book, has taken hold of Colombia's violences through gritty representations of drug trafficking, kidnappings, or dark tourism for the global market. It was only a matter of time for the cultural market to embrace the brand "postconflict" and to promote cultural goods that broadly address national reconciliation that can be globally recognized. While "Colombian violence" remains commodified and distributed in the global cultural market, the warfare conditions that informed cultural production in the 1990s and early 2000s are no longer forefronted (or, at least, not in the same way), as the brand "post-conflict" refocuses the Colombian condition toward violence through conflict resolution, peace, and national reconciliation.

One exemplary case of such "post-conflict" cultural commodification is Doris Salcedo's art installation Quebrantos [Shattered], which was 


\section{Epilogue}

organized by the Comisión de la Verdad [Truth Commission]. It took place in Bogotá's Plaza de Bolívar on June 10, 2019, and was widely reported in the international media as a communal pro-peace event to honor the memory of 165 social leaders violently murdered in Colombia since 2016. These lofty goals notwithstanding, Quebrantos is also a convincing case of Colombian art "for export" (the label that generally applies to most of Salcedo's oeuvre), for global media coverage, since it featured many elements that have long attracted attention of cultural producers and news outlets when it comes to violence in Colombia. This, of course, does not take anything away from the artistic qualities of the installation, much less from the suffering of the victims, but it is indicative of the emerging brand "post-conflict Colombia" in cultural events with clear global appeal beyond Colombia's national borders.

Using shattered glass, the installation outlined the names of slain social leaders in capital letters and spread them out on the ground of Plaza de Bolívar. In this iconic site for the nation's history, Salcedo's installation visually brings together two visual narratives: one originating in old colonial times and the State institutions, represented by the buildings encasing the Plaza (the Cathedral, the Congress, and the Supreme Court); and the other one literally shattering-from the ground-the steadiness of Colombia's political elite, who ultimately hold the responsibility for the unstoppable assassinations of community leaders. This visual contrast can be observed in the image below, which shows a victim's name spelled out in shattered glass on the ground leading the way toward the old colonial Cathedral's entrance (Figure 5.1).

Through impacting images like this, Quebrantos creates an act of collective national mourning for those who spoke against human rights violations, land grabs, illegal mining, deforestation, and drug trafficking in their local communities, and paid for their activism with their lives. The names of the victims remain on the ground outside the nation's symbolic center of political and ecclesiastical power. The victims are, nonetheless, present with their poignant names shattering the sites of power around the Plaza, as the warped reflection of the Cathedral, the Congress, Bogotá's City Hall (Palacio Liévano), and the Supreme Court on the broken glass produces fragmented and fractured images of such institutional buildings. This is brilliantly captured in a series of images by Italian photographer Viviana Peretti that details the buildings reflection on the shattered glass-the visual effect being one of distortion, shapelessness, inversion, and blurriness of the State institutions, as shown in this book's cover image. ${ }^{2}$ The old cathedral is visually torn apart on the shattered glass that spells out the slain social leaders' names, thus sending a powerful message to the very institutions that have allowed their murders. Through these reflective effects, these institutions are questioned for their failure to enact a plan to safeguard the lives of those who are on the frontlines of social activism and community leadership (Figure 5.2). 


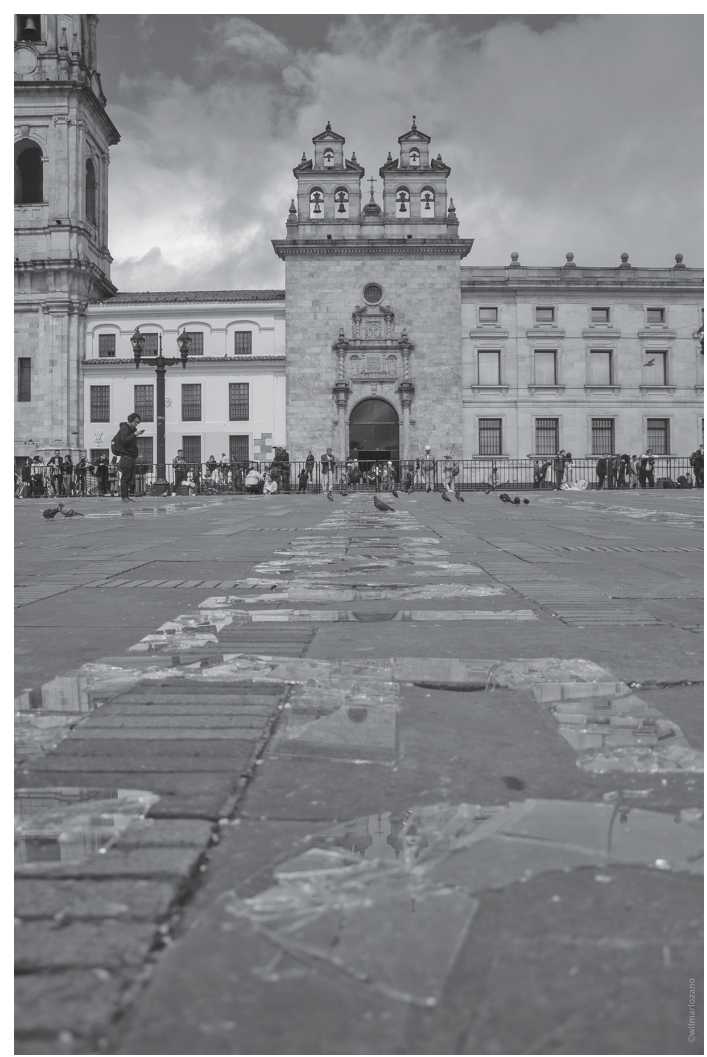

Figure 5.1 Detail of Doris Salcedo's Quebrantos. Patrimonio Cultural, Universidad Nacional de Colombia, 2019.

Furthermore, the sheer amount of shattered glass used for the art installation-i.e., the many broken lives it represented-was an invitation for everyone to reflect on the fragility of life in Colombia. The broken glass fragments represent the remnants of a seemingly never-ending conflict-fragments which had to be painstakingly placed by more than 200 volunteers who knew the slain social leaders well and worked together in initiatives in their local communities.

In this fashion, Quebrantos put on display the shattered lives of the victims and their families and friends, reminding everyone of the constant danger in their communities, as visually shown by the sharp edges of broken glass. One of the most poignant elements of the installation was precisely that the volunteers (mostly, family members and friends of the victims) had to handle the broken pieces of glass, risking deep cuts and possibly bleeding: first, by stepping hard on the large sheets of glass encased in wooden frames; second, by picking up the large and small 


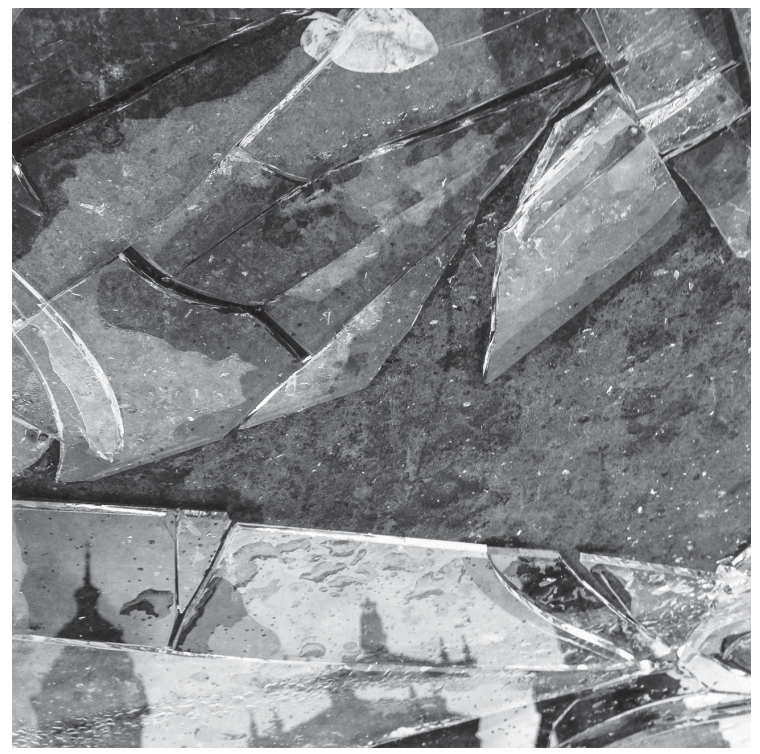

Figure 5.2 Detail of Doris Salcedo's Quebrantos. Courtesy of Viviana Peretti.

pieces of broken glass; and, finally, by handling the shattered glass to create the letters for the victims' names.

In this regard, Quebrantos is an act of collective mourning that sought to bring the victims back to life through broken pieces of shattered glass. Surely, it was an ephemeral installation that quickly turned the broken glass into debris ready to be collected by the sanitation department, ultimately bringing back the Plaza to regular order for the institutions of the State. But, as typically happens with the cleanup of confetti after a party, not all pieces can be successfully collected. It is then likely that minuscule fragments of shattered glass remain on the grounds of Plaza de Bolívar to memorialize the imprint of Quebrantos, producing miniature reflections of the broken State institution on the ground (if one were to look carefully). But, for Salcedo, the installation process of Quebrantos was what mattered most, not the ephemeral aspect for the artistic event: "by breaking glass, we are breaking silence, and, if we manage to break the silence of these piercing deaths, we will soon make the deaths stop" (Torrado). Wishful as this is, the reality of "post-conflict" murders in Colombia appears to be quite different. More than 250 social leaders have been killed in 2020 alone, and the mobility restrictions due to the pandemic have only made a small dent in the increasing roster of victims: "1,055 assassinated leaders between November 24, 2016, when the final Peace Accords were ratified, and November 3, 2020" (Ortiz). Indeed, Salcedo's words in an interview with EFE are very ominous of what is 
in store for Colombia and its cultural production: "El posconflicto lo estamos haciendo aún en la guerra" [Our post-conflict it is still being built in war]. And, thus, violence remains. And so does the cultural marketing and commodification of Colombia's violences.

\section{Notes}

1 For the differences between the original and revised accords, see "Comparación de los Acuerdos"; https://draftable.com/compare/JjypTOknafBktqvc.

2 For Peretti's photography, see http://vivianaperetti.com/blog/?p=4759. 


\section{Bibliography}

Abad Faciolince, Héctor. "Estética y narcotráfico." Revista de Estudios Hispánicos, vol. 42, 2008, pp. 513-518.

- Oblivion: A Memoir. Translated by Héctor Joaquín and Anne McLean. Old Street, 2010.

-. El olvido que seremos. Alfaguara, 2006.

El abrazo de la serpiente. Directed by Ciro Guerra, Buffalo Films, Caracol Televisión, 2015.

Los abrazos del río. Directed by Nicolás Rincón Gille, VOA, 2010.

Acevedo Arango, Óscar Fernando. Geografías de la memoria: posiciones de las víctimas en Colombia en el periodo de la justicia transicional. Editorial Pontificia Universidad Javeriana, 2012.

Adorno, Theodor. "The Culture Industry Reconsidered." The Culture Industry. Routledge, 1991. pp. 98-106.

Adorno, Theodor W., and Max Horkheimer. "The Culture Industry: Enlightenment as Mass Deception." Dialectic of Enlightenment. Edited by Mieke Bal and Hent de Vries. Stanford University Press, 2002, pp. 94-137.

Agarrando pueblo. Directed by Luis Ospina and Carlos Mayolo, SATUPLE, 1977.

Anderson, Benedict. Imagined Communities: Reflections on the Origins and Spread of Nationalism. Verso, 2016.

Appadurai, Arjun. La modernidad desbordada: dimensiones culturales de la globalización. Translated by Gustavo Remedi. Fondo de Cultura Económica, 2001.

- Modernity at Large. Cultural Dimensions of Globalization. University of Minnesota Press, 1996.

Arendt, Hannah. On Violence. Harcourt, 1969.

Arias, María Alejandra, et al., editors. Costos económicos y sociales del conflicto en Colombia: ¿cómo construir un posconflicto sostenible? Universidad de los Andes, 2014.

Aristizábal Juanita, and Juliana Martínez, editors. "Violent Tales: Cultural Representation in Colombia and Mexico." Revista de Estudios Hispánicos, vol. 53, no. 1, 2019, pp. 7-259. DOI: 10.1353/rvs.2019.0003.

Un asunto de tierras. Directed by Patricia Ayala, Pathos Audiovisual, 2015.

Baker, Jennifer M. The Tactile Eye: Touch and the Cinematic Experience. University of California Press, 2009.

Balderston, Daniel. "Ética y sexualidad en la ficción autobiográfica de Fernando Vallejo." El deseo, enorme cicatriz luminosa: ensayos sobre homosexualidades latinoamericanas. Beatriz Viterbo, 2004. 
¡Basta ya! Colombia: memorias de guerra y dignidad. Centro Nacional de Memoria Histórica, 2013. www.centrodememoriahistorica.gov.co/micrositios/ informeGeneral/

BBC Radio. "Ingrid Betancourt believes no ransom was paid.” 7 July 2008. www. bbc.co.uk/worldservice/news/2008/07/080708_betancourt_sl.shtml

Benavides, Hugo O. Drugs, Thugs, and Divas: Telenovelas and Narco-Dramas in Latin America. University of Texas Press, 2008.

Benjamin, Walter. "Critique of Violence." On Violence: A Reader. Edited by Lawrence, Bruce B, and Aisha Karim. Duke University Press, 2007, pp. 268-285.

Bernal, Álvaro. "Cultura urbana e identidad sexual en La virgen de los sicarios de Fernando Vallejo: el desarraigo de un intelectual ante la realidad desesperanzadora de su nación.” Brújula, vol. 1, 2002, pp. 63-72.

Betancourt, Ingrid. The Blue Line. Penguin, 2016.

. Even Silence Has an End. Read by Margaret Nichols. Recorded Books, 2010. CD.

- Even Silence Has and End: My Six Years of Captivity in the Colombian Jungle. Translated by Steven Rendall. Penguin, 2010.

- La ligne blene. Gallimard, 2014.

-. A linha azul. Alfaguara, 2015.

- Même le silence a une fin. Gallimard, 2010.

—. No hay silencio que no termine. Translated by María Mercedes Correa, Mateo Cardona, and Ingrid Betancourt. Aguilar/Santillana, 2010.

- 2002. Until Death Do Us Part. Harper, 2008.

- Until Death Do Us Part: My Struggle to Regain Colombia. Translated by Steven Rendall. Ecco, 2002.

Betancourt, Ingrid, and Lorenzo Delloye-Betancourt. Cartas a mamá: desde el infierno. Debate, 2008.

Beverley, John. Testimonio: On the Politics of Truth. University of Minnesota Press, 2004.

Bhabha, Homi K. The Location of Culture. Routledge, 1994.

Blanton, Casey. Travel Writing: The Self and the World. Routledge, 2002.

El blog del narco. https://elblogdelnarco.com/

Bolaño, Roberto. Nocturno de Chile. Anagrama, 2000.

. Estrella distante. Anagrama, 1996.

Bolívar Moreno, Gustavo. Sin tetas no hay paraíso. Quintero Editores, 2007.

Bongco, Mila. Reading Comics: Language, Culture and the Concept of the Superhero in Comic Books. Routledge, 2013.

"Books. Bestsellers. Hardcover Non Fiction." The New York Times. 10 October 2010. www.nytimes.com/best-sellers-books/2010-10-10/hardcovernonfiction/list.html

Boström, Magnus. "The Social Life of Mass and Excess Consumption." Environmental Sociology, vol. 6, no. 3, 2020, pp. 268-278. DOI: 10.1080/ 23251042.2020.1755001.

Brinkema, Eugenie. The Forms of the Affects. Duke University Press, 2014.

Britto, Lina. Marijuana Boom: The Rise and Fall of Colombia's First Drug Paradise. University of California Press, 2020.

Brodzinsky, Sibylla, and Max Schoening. Throwing Stones at the Moon: Narratives from Colombians Displaced by Violence. McSweeney's Books, 2012.

Bruce, Victoria, and Karin Hayes. Hostage Nation: Colombia's Guerrilla Army and the Failed War on Drugs. Knopf, 2010. 


\section{Bibliography}

Bruno, Giuliana. 2002. Atlas of Emotion: Journeys in Art, Architecture, and Film. Verso, 2011.

Bushnell, David. The Making of Modern Colombia: A Nation in Spite of Itself. University of California Press, 1993.

Cabañas, Miguel, editor. "Imagined Narcoscapes: Narcoculture and the Politics of Representation." (special issue of) Latin American Perspectives, vol. 41-42, 2014, pp. 3-235.

- "El narcocorrido global y las identidades transnacionales." Revista de Estudios Hispánicos, vol. 42, 2008, pp. 519-542.

Campos, Minerva. "Nuevo cine colombiano: lo(s) nuevo(s), lo auténtico y el factor Proimágenes." Cinémas d'Amérique Latine, vol. 25, 2017, pp. 118133. DOI: $10.4000 /$ cinelatino.4696.

El capo. Directed by Riccardo Gabrielli R. Lilo Vilaplana, RCN, 2009.

Carta a una sombra. Directed by Daniela Abad and Miguel Salazar, La Esperanza, 2015.

Cartel Land. Directed by Matthew Heineman. A\&E Indie Films, 2015.

El cartel de los sapos. Directed by Luis Alberto Restrepo, Caracol TV, 2008.

Castillejo-Cuéllar, Alejandro. "Iluminan tanto como oscurecen: de las violencias y las memorias de las violencias en la Colombia actual." Memoria, silencio y acción psicosocial: reflexiones criticas sobre por qué recordar en Colombia. Edited by Edgar Barrero Cuéllar. Ediciones Cátedra Libre, 2010.

_. "La paz en pequeña escala: fracturas de la vida cotidiana y las políticas de la transición en Colombia." Revista de Estudios Colombianos, vol. 53, 2019, pp. 6-10.

Castillejo-Cuéllar, Alejandro, and Fredy Leonardo Reyes Albarracín, editors. Violencia, memoria y sociedad: debates y agendas en la Colombia actual. Universidad Santo Tomás, 2013.

Centro de Memoria, Paz y Reconciliación. Bogotá. centromemoria.gov.co

Centro Nacional de Memoria Histórica. Bogotá. centrodememoriahistorica.gov. $\mathrm{co} /$

Cepeda, María Helena. Musical ImagiNation: U.S-Colombian Identity and the Latin Music Boom. NYU Press, 2010.

Chao, Ramón. 1994. Mano Negra en Colombia: un tren de bielo y fuego. Cybermonde, 2001.

- The Train of Ice and Fire: Mano Negra in Colombia. Translated by Ann Wright. Route, 2010.

Chico, Camilo, and Benjamín Villegas. Alejandro Obregón. Villegas Editores, 2011.

Chocó. Directed by Jhonny Hendrix Hinestroza, Antorcha Films, 2012.

Coghlan, Nicholas. The Saddest Country: On Assignment in Colombia. McGillQueen's University Press, 2004.

Los colores de la montaña. Directed by Carlos César Arbeláez. El Bus Productions, Jaguar Films, 2011.

"Comparación de los Acuerdos de Paz en Colombia" (Nuevo Acuerdo Final, 12 November 2016). draftable.com/compare/JjypTOknafBktqvc

“Confirmado: Carlos Castaño está muerto." Semana. 8 March 2006. www.semana. com/on-line/articulo/confirmado-carlos-castano-esta-muerto/80598-3/ \#: :text=La \%20muerte \%20de \%20Castaño \%2C\%20asesinado,Carlos \%20 para $\% 20$ que $\% 2010 \% 20$ traicionara 
Couret, Nilo. "El movimiento de los cuerpos: afecto, emoción y cine popular latinoamericano.” Hispanófila, vol. 177, 2016, pp. 156-166.

Crownshaw, Richard, editor. The Future of Memory. Berghahn Books, 2010.

Daroqui, María Julia, and Eleonora Cróquer, editors. Mercado, editoriales y difusión de discursos culturales en América Latina [special issue]. Revista Iberoamericana, vol. 197, 2001, pp. 653-793.

Davis, Rocío G. "Documentary Constructions of Filial Memory in Nathaniel Kahn's My Architect and Nicolás Entel's My Father, Pablo Escobar." Journal of Film and Video, vol. 66, no. 1, Spring 2014, pp. 52-61. DOI: 10.5406/ jfilmvideo.66.1.0052.

De la Fuente, Anne Marie. "Pics, TV Drive Two-Way Street in Colombia” Variety, vol. 412, 2008, p. 20.

De Maeseneer, Rita, and Jasper Verkaeke. "Sensaciones, sonidos y silencios en El ruido de las cosas al caer de Juan Gabriel Vásquez." Revista Chilena de Literatura, vol. 101, May 2020, pp. 405-425.

La desazón suprema: retrato incesante de Fernando Vallejo. Directed by Luis Ospina, Ministerio de Cultura de Colombia, Consejo Nacional de Cultura y de las Artes de México (CONACULTURA), 2003.

Dudley, Steven S. Walking Ghosts: Murder and Guerrilla Politics in Colombia. Routledge, 2004.

Entourage. Created by Doug Ellin, HBO, 2004-2011.

Erlick, June Carolyn. A Gringa in Bogotá: Living Colombia's Invisible War. University of Texas Press, 2010.

Erll, Astrid. Memory in Culture. Palgrave, 2011.

Escobar, Juan Pablo. Pablo Escobar: mi padre. Planeta, 2014.

Escobar: Paradise Lost. Directed by Andrea Di Stefano, Pathé, 2014.

Faguet, Michèle. "Pornomiseria: Or How to Make a Documentary Film." Afterall: A Journal of Art, Context and Enquiry, vol. 21, Summer 2009, pp. 5-11. DOI: 10.1086/aft.21.20711744.

Falicov, Tamara L. "Programa Ibermedia Co-Production and the Cultural Politics of Constructing an Ibero-American Audiovisual Space.” Spectator, vol. 27, no. 2, Fall 2007, pp. 21-30.

Fanta Castro, Andrea. Residuos de la violencia: producción cultural colombiana, 1990-2010. Universidad del Rosario, 2015.

Fanta Castro, Andrea, Alejandro Herrero-Olaizola, and Chloe Rutter-Jensen, editors. Territories of Conflict: Traversing Colombia Through Cultural Studies. University of Rochester Press, 2017.

FARC Bloque Martín Caballero (ETCR Amaury Rodríguez, La Guajira). www. resistencia-colombia.org/

Fattal, Alexander L. Guerrilla Marketing: Counterinsurgency and Capitalism in Colombia. University of Chicago Press, 2018.

Feiling, Tom. Cocaine Nation: How the White Trade Took Over the World. Pegasus, 2009. [originally The Candy Machine: How Cocaine Took Over the World. Penguin, 2009].

- Short Walks from Bogotá: Journeys in the New Colombia. Allen Lane (Penguin), 2012.

Fernández L'Hoeste, Héctor. "From Rodrigo to Rosario: Birth and Rise of the Sicaresca." Revista de Estudios Hispánicos, vol. 42, 2008, pp. 543-558.

Ferry, Stephen. Violentología: un manual del conflicto colombiano. Ícono, 2012. 


\section{Bibliography}

Forero, Gustavo. "La anomia en las novelas de crímenes en Colombia." Literatura y Lingüística, vol. 24, 2011, pp. 33-59. DOI: 10.4067/S071658112011000200003.

Franco, Jean. Cruel Modernity. Duke University Press, 2013.

Franco, Jorge. Rosario Tijeras. Siete Cuentos, 1999.

Fuerza Alternativa Revolucionaria del Común. www.farc-ep.co/

García Márquez, Gabriel. El amor en los tiempos del cólera. Editorial Oveja Negra, 1985.

. Cien años de soledad. Sudamericana, 1967.

—. One Hundred Years of Solitude. Translated by Gregory Rabassa. Knopf, 1995.

Garde-Hansen, Joanne. Memory and Media. University of Edinburgh Press, 2011.

Gente de papel. Directed by Andrés Felipe Vásquez. Makerule Media, 2014.

Goellnicht, Donald. “'Ethnic Literature's Hot': Asian American Literature, Refugee Cosmopolitanism, and Nam Le's The Boat." Journal of Asian American Studies, vol. 15, no. 2, 2012, pp. 197-224. DOI: 10.1353/jaas. 2012.0016.

Gómez Gutiérrez, Felipe. "Filmar en desacuerdo: disenso, ruina, afecto y recuerdo en el documental Todo comenzó por el fin de Luis Ospina." Revista de Estudios Colombianos, vol. 55, 2020, pp. 19-29.

- "National Identity in Colombian Comics: Between Violence and New Configurations." Territories of Conflict: Traversing Colombia Through Cultural Studies. Edited by Andrea Fanta Castro, Alejandro Herrero-Olaizola, and Chloe Rutter-Jensen. University of Rochester Press, 2017, pp. 49-68.

Gómez Tovar, José Crisanto. El hijo de la selva. Planeta, 2010.

Gonsalves, Marc, et al. Lejos del infierno: una odisea de 1.967 dias en manos de las FARC. Planeta, 2009.

- Out of Captivity: 1,967 Days in the Colombian Jungle. Harper Collins, 2009.

Gootenberg, Paul. Andean Cocaine: The Making of a Global Drug. University of North Carolina Press, 2008.

Gould, Terry. Marked for Death: Dying for the Story in the World's Most Dangerous Place. Counterpoint, 2009.

Gregg, Melissa, and Gregory Seigworth, editors. The Affect Theory Reader. Duke University Press, 2010.

Guerra Molina, René Alonso. "El papel del patrimonio cultural en el escenario del posconflicto en Colombia: paisaje, patrimonio cultural y memoria de la construcción de paz.” Memorias, vol. 39, 2019, pp. 116-141. DOI: 10.14482/ memor.39.303.66.

Gutiérrez, Pedro Juan. 1998. Trilogía sucia de La Habana. Anagrama, 2006.

Hammer, Joshua. "Inside the Trap." The New York Review. 9 December 2010, pp. 22-24.

Heggstad, Glen. 2004. Two Wheels Through Terror: Diary of a South American Motorcycle Odyssey. ECW Press, 2010.

Heli. Directed by Amat Escalante, Mantarraya, 2013.

Henseler, Christine, and Alejandro Herrero-Olaizola, editors. Market Matters [special section]. Arizona Journal of Hispanic Cultural Studies, vol. 9, 2005, pp. 113-217. DOI: 10.1353/hcs.2011.0216.

Herlinghaus, Hermann. Narco-Epics: A Global Aesthetics of Sobriety. Bloomsbury, 2013. 
Palgrave, 2009.

Herrero-Olaizola, Alejandro. "Crimen sin castigo: narco dramas para el mercado global." Edited by Gustavo Forero. Crimen y control social. Enfoques desde la literatura. Universidad de Antioquia, 2012, pp. 111-117.

—. "Edición local para el nuevo milenio: el best seller sucio y la corporación cultural." Cuadernos de Literatura, vol. 32, 2012, pp. 288-305.

_. "El mercado del crimen: ética y justicia poética en Nam Le." Novela negra y otros crimenes. Edited by Gustavo Forero. Planeta, 2013, pp. 253-263.

- "Se vende Colombia, un país de delirio: el mercado editorial global y la nueva narrativa colombiana reciente." Symposium: Quarterly Journal in Modern Literatures, vol. 61, no. 1, 2007, pp. 43-56. DOI: 10.3200/ SYMP.61.1.43-56.

"Histórico de Resultados Electorales." Registraduría Nacional del Estado Civil, República de Colombia. www.registraduria.gov.co/-Historico-deResultados-3635-

Hodgkin, Katherine, and Susannah Radstone, editors. Regimes of Memory. Routledge, 2011.

Holland, Patrick and Graham Huggan. Tourists with Typewriters: Critical Reflections of Contemporary Travel Writing. University of Michigan Press, 1998.

Los hongos. Directed by Óscar Ruiz Navia, Burning Blue, 2014.

Hoyos, Héctor. Beyond Bolaño: The Global Latin American Novel. Columbia University Press, 2016.

Huggan, Graham. Extreme Pursuits: Travel/Writing in an Age of Globalization. University of Michigan Press, 2009.

Huyssen, Andreas. Present Pasts: Urban Palimpsests and the Politics of Memory. Stanford University Press, 2003.

- Twilight Memories: Marking Time in a Culture of Amnesia. Routledge, 1995.

Hylton, Forrest. Evil Hour in Colombia. Verso, 2006.

Idler, Annette. Borderland Battles: Violence, Crime, and Governance at the Edges of Colombian War. Oxford University Press, 2019.

Ingrid de la selva. 9 February 2001. resistencia-colombia.org/index.php/component/content/article/22-farc-ep/publicaciones/926-ingrid-de-la-selva (no longer active; accessed on 8 August 2014).

Jacobs, Michael. The Robber of Memories: A River Journey Through Colombia. Granta Books, 2012.

Jaramillo, María Mercedes. "Fernando Vallejo: desacralización y memoria." Literatura y cultura: narrativa colombiana del siglo XX. Diseminación, cambios, desplazamientos vol. II. Ministerio de Cultura, 2000.

“Justicia transicional en Colombia." Ministerio de Justicia y Derecho. 2015. www.justiciatransicional.gov.co/Justicia-Transicional/Justicia-transicionalen-Colombia

Kantaris, Elia Geoffrey, and O’Bryen, Rory, editors. Latin American Popular Culture: Politics, Media, Affect. Tamesis, 2013.

Lafuente, J., and S. Palomino. "Esta será la pregunta para el plebiscito por la paz en Colombia." El País. 30 August 2016.

Lander, María Fernanda. "Narcogeografías." Revista de Estudios Hispánicos, vol. 42, 2008, pp. 505-512. 


\section{Bibliography}

Lawrence, Bruce B., and Aisha Karim, editors. On Violence: A Reader. Duke University Press, 2007.

Lazzara, Michael. Chile in Transition. The Poetics and Politics of Memory. University of Florida Press, 2016.

Le, Nam. El barco. Translated by Ignacio Gómez Calvo and Marc Viaplana. Random House/Mondadori, 2010.

The Boat. Knopf, 2008.

. The Boat (Audible Audio Edition). Recorded Books, 2009.

Leech, Garry. Beyond Bogotá: Diary of a Drug War Journalist in Colombia. Beacon Press, 2009.

. The FARC: The Longest Insurgency. Zed Books, 2011.

Leenhardt, Pierre, and Jean-Marc Ayrault. Il était une fois ... cargo 92: Royal de luxe, Mano Negra, Philippe Decouflé, Philippe Genty sur la route de Christophe Colomb. Actes Sud, 2013.

Lemay Langlois, Léa, et al. ¿Ideología o perspectiva de género en la justicia transicional? Universidad Externado, 2019.

Lennon, J. John, and Malcolm Foley. Dark Tourism: The Attraction of Death and Disaster. Continuum, 2000. DOI: 10.1016/S0261-5177(01)00055-3.

León, Juanita. Country of Bullets: Chronicles of War. Translated by Guillermo Bleichmar. University of New Mexico Press, 2009.

- País de plomo: crónicas de guerra. Aguilar, 2005.

Leonard, Stephen P. "Voices from the Outside: The Instrumentality of Radio Message in Colombian Kidnappings." Language and Communication, vol. 69, no. 1, 2019, pp. 1-10. DOI: 10.1016/j.langcom.2019.04.005.

Ley de Cine, Ley 814. www.proimagenescolombia.com//secciones/proimagenes/ interna.php?nt=8

Ley de Víctimas y Restitución de Tierras, Ley 1448. www.centrodememoriahistorica. gov.co/micrositios/caminosParaLaMemoria/descargables/ley1448.pdf

Lisle, Debbie. The Global Politics of Contemporary Travel Writing. Cambridge University Press, 2006. DOI: 10.1017/CBO9780511491535.

Lobo, Gregory. Colombia: algo diferente de una nación. Universidad de los Andes, 2009.

López de Abiada, José Manuel. "Entre el ocio y el negocio. Para una pragmática del best-séller." Éxito de ventas y calidad literaria: incursiones en las teorías y prácticas del best-séller. Edited by José Manuel López de Abiada and José Peñate Rivero. Editorial Verbum, 1993, pp. 15-52.

López, Andrés. El cartel de los sapos. Planeta, 2008.

López, Gustavo. "Hispanics of Colombian Origin in the United States, 2013." Pew Research Center. www.pewresearch.org/hispanic/2015/09/15/hispanicsof-colombian-origin-in-the-united-states-2013/.

Loving Pablo. Directed by Fernando León, Escobar Films, B2Y Productions, 2017.

Lugo Vivas, Diego Andrés. “ 'Prosperity for Everyone' in the Post-Conflict?: How Does Environmentally and Militarily Oriented State (Re)Control in the Ariari Region Propel Productive Segmentation and Social Fracturing?" Revista de Estudios Colombianos, vol. 53, 2019, pp. 103-120.

Madonna and Maluma. "Medellín." Madame X, Interscope Records, 2019.

Malagón, Camilo. "Post-Conflict Visual Ecologies: Violence and Slow Violence in Chocó by Jhonny Hendrix Hinestroza and La tierra y la sombra by César Augusto Acevedo. Revista de Estudios Colombianos, vol. 55, 2020, pp. 30-41. 
Marks, Laura. The Skin of Film: Intercultural Cinema, Embodiment, and the Senses. Duke University Press, 2000.

Martin, Deborah. Painting, Literature and Film in Colombian Feminine Culture, 1940-2005: Of Border Guards, Nomads and Women. Boydell \& Brewer, 2012.

Martín-Barbero, Jesús. Al sur de la modernidad: comunicación, globalización y multiculturalidad. IILI, 2001.

Martínez, Juliana. "Competing Visions and Contested Spaces in La sirga and Colombia magia salvaje." Revista de Estudios Hispánicos, vol. 53, no. 1, 2019, pp. 121-142. DOI: 10.1353/rvs.2019.0004.

- Haunting without Ghosts: Spectral Realism in Colombian Literature, Film, and Art. University of Texas Press, 2020.

Martínez-Durán, Angélica. The Politics of Drug Violence. Criminals, Cops and Politicians in Colombia and Mexico. Oxford University Press, 2018.

Masiello, Francine. "La insoportable levedad de la historia: los relatos best seller de nuestro tiempo." Revista Iberoamericana, vol. 193, 2000, pp. 799-814. DOI: 10.5195/REVIBEROAMER.2000.5817.

Massumi, Brian. The Politics of Affect. Polity, 2015.

McKinney, Mark. History and Politics in French-Language Comics and Graphic Novels. University Press of Mississippi, 2008.

Menchú, Rigoberta (with Elisabeth Burgos). Me llamo Rigoberta Menchú y así me nació la conciencia. Siglo XXI, 1983.

Mendoza, Élmer. 1999. Un asesino solitario. Tusquets, 2013.

- 2008. Balas de plata. Tusquets, 2011.

Mendoza, Mario. Satanás. Seix Barral, 2002.

La milagrosa. Directed by Rafael Lara, Verasur Films, 2008.

Mira Olano, Luz Elena, et al. "Factibilidad, implementación y seguimiento en Colombia de la justicia especial para la paz frente a la estructura de la justicia transicional." Opinión Jurídica, vol. 17, no. 35, 2018, pp. 43-67. DOI: 10.22395/ojum.v17n35a2.

Miss Bala. Directed by Catherine Hardwicke, Columbia Pictures, 2019.

Miss Bala. Directed by Gerardo Naranjo, Canana Films, 2011.

Molano, Alfredo. The Dispossessed: Chronicles of the Desterrados of Colombia. Translated by Daniel Bland. Haymarket Books, 2005.

Mollison, James (with Rainbow Nelson). The Memory of Pablo Escobar. Christ Boot, 2007.

Monos. Directed by Alejandro Landes, Stela Cine, 2019.

Monsiváis, Carlos, et al., editors. Viento rojo: diez historias del narco en México. Plaza \& Janés, 2004.

Moraña, Mabel, and Ignacio M. Sánchez Prado, editors. El lenguaje de las emociones: afecto y cultura en América Latina. Iberoamericana Vervuert, 2012.

Moreiras-Menor, Cristina. Cultura herida: literatura y cine en la España democrática. Libertarias, 2002.

La mujer del animal. Directed by Víctor Gaviria, Polo a Tierra, Viga Producciones, 2016.

Las muñecas de la mafia. Directed by Luis Alberto Restrepo, Caracol TV, 2009.

Muñoz Sarmiento, Luis Carlos. "La virgen de los sicarios." Revista de la Universidad de Antioquia, vol. 265, 2001, pp. 112-114.

Murillo, Javier H. "Prólogo." El río del tiempo. Alfaguara, 1998.

. "La voz y el criminal: un análisis de La virgen de los sicarios." Cuadernos de literatura, vol. 7, 2001, pp. 241-249. 


\section{Bibliography}

Museo Casa de la Memoria. Medellín. www.museocasadelamemoria.gov.co Museo de la Memoria. Santiago. ww3.museodelamemoria.cl/sobre-el-museo/ Museo Nacional de la Memoria. Bogotá. museodememoria.gov.co/

Museo Sitio de Memoria ESMA. Buenos Aires. www.museositioesma.gob.ar Narcos. Directed by José Padilha, Netflix, 2015.

Narco Cultura. Directed by Shaul Schwarz, Ocean Side Pictures, 2013.

La negociación. Directed by Margarita Martínez, La Retratista, 2018.

Neiger, Motti, et al. On Media Memory: Collective Memory in a New Media Age. Palgrave Macmillan, 2011.

Neruda, Pablo. "Para todos." Pablo Neruda: Five Decades, a Selection of Poems (1925-1970). Translated by Ben Belitt. Grove P, 1974.

"Nueva obra de Doris Salcedo en honor a los líderes sociales asesinados en Colombia.” Agencia EFE, Bogotá. 10 June 2020. www.youtube.com/watch?v= 7VaR37hDzNg

“Los números que dejaríamos atrás.” El Tiempo. 2 October 2016.

O'Bryen, Rory. "Affect, Politics and the Production of the People: Meditations on the Río Magdalena." Latin American Popular Culture: Politics, Media, Affect. Edited by Geoffrey Kantaris and Rory O'Bryen. Boydell and Brewer, 2013, pp. 227-248.

- Literature, Testimony and Cinema in Contemporary Colombian Culture: Specters of Violence. Tamesis Books, 2008.

Ochoa-Cubillos, Andrés Felipe. "Derechos humanos y estándares laborales en las organizaciones, de cara al posconflicto en Colombia." Jangwa Pana, vol. 16, 2017, pp. 38-54. DOI: 10.21676/16574923.1955.

Olick, Jeffrey, et al., editors. The Collective Memory Reader. Oxford University Press, 2011.

El olvido que seremos. Directed by Fernando Trueba, Caracol TV, 2020.

Operación E. Directed by Miguel Courtois, RTVE, Canal +, 2012.

Operación Jaque. Directed by Silvia Quer, RTVE, Caracol TV, 2010.

Ortiz Abella, J.G. Operación Jaque: secretos no revelados. Oveja Negra, 2008.

Ortiz, María Isabel, and Julián Ríos Monroy. "Más de 250 líderes han sido asesinados este año, según Indepaz.” El Tiempo. 8 November 2020. www. eltiempo.com/justicia/investigacion/lideres-sociales-cifras-de-asesinatossubieron-en-el-2020-pese-a-la-pandemia-547693

Osorio Calvo, Carlos Alberto. Pueblos indígenas: paz y posconflicto. Universidad Santiago de Cali Editorial, 2018.

Osorio, Óscar. "El sicario en la novela colombiana.” Poligramas, vol. 29, 2008, pp. 61-81.

Ospina Pizano, María. "Evocar y convocar: violencia y representación en la narrativa colombiana de fines del siglo XX." $\mathrm{PhD}$ dissertation. Harvard University, 2009.

—. "Natural Plots: The Rural Turn in Contemporary Colombian Cinema." Territories of Conflict: Traversing Colombia Through Cultural Studies. Edited by Andrea Fanta Castro, Alejandro Herrero-Olaizola, and Chloe RutterJensen. University of Rochester Press, 2017, pp. 248-266.

- El rompecabezas de la memoria. Literatura, cine y testimonio de comienzos de siglo en Colombia. Iberoamericana, 2019.

Pájaros de verano. Directed by Cristina Gallego and Ciro Guerra, Ciudad Lunar, 2018. 
Palacios, Marco. Violencia pública en Colombia, 1958-2010. Fondo de Cultura Económica, 2012.

Palaversich, Diana. "The Politics of Drug Trafficking in Mexican and MexicoRelated Narconovelas" Aztlán, vol. 31, 2006, pp. 85-110.

El páramo. Directed by Jaime Osorio Márquez, Alta Films, 2011.

Paternostro, Silvana. My Colombian War: A Journey Through the Country I Left Behind. Henry Holt, 2007.

El patrón del mal. Directed by Carlos Moreno, Caracol TV, 2012.

Pecados de mi padre. Directed by Nicolás Entel, Red Creek Productions, 2009.

Pécaut, Daniel. La experiencia de la violencia: los desafíos del relato y la memoria. La Carreta Editores E.E., 2013.

Peretti, Viviana. “Quebrantos by Doris Salcedo.” Photo Blog. 11 June 2019. vivianaperetti.com/blog/?p=4759

Pérez-Reverte, Arturo. La reina del sur. Alfaguara, 2002.

La Playa D.C. Directed by Juan Andrés Arango, Burning Blue, 2012.

Pobutsky, Aldona Bialowas. Pablo Escobar and Colombian Narcoculture. University of Florida Press, 2020.

- "Towards the Latin American Action Heroine: The Case of Jorge Franco Ramos' Rosario Tijeras.” Studies in Latin American Popular Culture, vol. 24, 2005, pp. 17-35.

Podalsky, Laura. "The Affect Turn.” New Approaches to Latin American Studies. Edited by Juan Poblete. Routledge, 2018, pp. 237-254. DOI: 10.4324/ 9781315158365-16.

- The Politics of Affect and Emotion in Contemporary Latin American Cinema: Argentina, Brazil, Cuba and Mexico. Palgrave Macmillan, 2011.

Polit Dueñas, Gabriela. Narrating Narcos: Culiacán and Medellín. University of Pittsburgh Press, 2013.

—. "Sicarios, delirantes y los efectos del narcotráfico en la literatura colombiana.” Hispanic Review, vol. 74, no. 2, Spring 2006, pp. 119-142.

Pratt, Mary Louise. Imperial Eyes. 2nd edition. Routledge, 2008.

Proimágenes Colombia. proimagenescolombia.com//

"Ransom Claim in Betancourt Release." The Guardian. 4 July 2008. theguardian. com/world/2008/jul/04/betancourt.france

Raz, Guy, host. "Interview with Nam Le: The Boat Takes Readers Across the World." All Things Considered, NPR, 24 May 2008, www.npr.org/templates/ story/story.php? storyId=90805104? storyId=90805104

Reber, Dierdra. Coming to Our Senses: Affect and an Order of Things for Global Culture. Columbia University Press, 2016.

La reina del sur. Directed by Mario Cruz, Telemundo, 2011.

Restrepo, Laura. Delirio. Alfaguara, 2004.

Restrepo Salazar, Juan Camilo. La cuestión agraria: tierra y posconflicto en Colombia. Debate, 2014.

Reyes, Elizabeth. "El conflicto armado en Colombia deja 220.000 muertos desde 1958.” El País. 24 July 2013.

Riaño, Pilar, and María Victoria Uribe. "Construyendo memoria en medio del conflicto: el Grupo de Memoria Histórica de Colombia.” Revista de Estudios Hispánicos, vol. 50, julio-diciembre 2017, pp. 9-23.

Ricoeur, Paul. Memory, History, Forgetting. University of Chicago Press, 2004. 


\section{Bibliography}

Rivera, José Eustasio. 1924. La vorágine. Prologue by Juan Loveluck. Biblioteca Ayacucho, 1976.

Rocha, Carolina. "Cine colombiano en el siglo XXI: balance de las coproducciones colombianas con Europa." Journal of Iberian and Latin American Research, vol. 24, no. 2, 2018, pp. 123-137. DOI: 10.1080/13260219.2018.1536761.

Rodrigo D: no futuro. Directed by Víctor Gaviria, FOCINE, 1990.

Rodríguez, Ileana. "The Violent Text: Separating the Social and the Political." Liberalism at Its Limits. University of Pittsburgh Press, 2009. pp. 95-114.

Rojas, Clara (con Isabel García-Zara). Captive: 2147 Days of Terror in the Colombian Jungle. Translated by Adriana V. López. Simon \& Schuster, 2009.

- Cautiva: testimonio de un secuestro. Atria Español, Simon \& Schuster, 2009.

Rosario Tijeras. Directed by Emilio Maillé, Río Negro, 2005.

Rosenberg, Fernando J. After Human Rights: Literature, Visual Arts, and Film in Latin America, 1990-2010. University of Pittsburgh Press, 2016. DOI: 10.2307/j.ctt1n2tx5p.

RTVE. "Silvia Quer: 'Era un gran aventura profesional y personal.'” 1 August 2011. www.rtve.es/television/20110801/silvia-quer-era-gran-aventuraprofesional-personal-no-dude-aceptar/451500.shtml

Rueda, María Helena. "Escrituras del desplazamiento. Los sentidos del desarraigo en la narrativa colombiana reciente." Revista Iberoamericana, vol. 207, 2004, pp. 391-408.

- "Violencia, pérdidas y duelo en el cine colombiano reciente." Revista de Estudios Hispánicos, vol. 53, no. 1, 2019, pp. 99-120. DOI: 10.1353/ rvs.2019.0012.

—. La violencia y sus huellas: una mirada desde la narrativa colombiana. Iberoamericana, 2011.

Rueda Esteban, Rocío, and Jorge Bonilla. "Turismo y posconflicto en el municipio de la Macarena, Meta - Colombia." Revista Iberoamericana de Turismo, vol. 7, no. 1, 2020, pp. 114-134.

Said, Edward. Orientalism. Pantheon, 1978.

Salazar, Alonso. No nacimos pa' semilla: la cultura de las bandas juveniles de Medellín. CINEP, 1990.

- Pablo Escobar, el patrón del mal. Aguilar, 2012.

La parábola de Pablo. Planeta, 2001.

Salcedo, Doris. Interview. Agencia EFE, Bogotá. 10 June 2020.

- Quebrantos. Plaza Bolívar, Bogotá, Colombia. 10 June 2020.

Sánchez, Gonzalo, and Ricardo Peñaranda, editors. Pasado y presente de la violencia en Colombia. La Carrera Editores, 2007.

Sassen, Saskia. Territory, Authority, Rights: from Medieval to Global Assemblages. Princeton University Press, 2006.

Saviano, Roberto. Cero Cero Cero: cómo la cocaína gobierna el mundo. Translated by Mario Costa García. Anagrama, 2014.

Schuster, Sven. "The Duty of Memory: La Violencia between Remembrance and Forgetting." Territories of Conflict: Traversing Colombia Through Cultural Studies. Edited by Andrea Fanta Castro, Alejandro Herrero-Olaizola, and Chloe Rutter-Jensen. University of Rochester Press, 2017, pp. 37-48.

Scotto, Serge. "Ingrid de la jungle: un BD parodique." 21 September 2010. www. youtube.com/watch?v=NLa7loVGhHM 
Scotto, Serge, et al. Ingrid de la jungle. Editions Fluide Glacial, 2010.

Señorita María, la falda de la montaña. Directed by Rubén Mendoza, DíaFragma, Fábrica de Películas, 2017.

Sharpley, Richard, and Philip Stone. The Darker Side of Travel: The Theory and Practice of Dark Tourism. Channel View Publications, 2009.

Sicario. Directed by Denis Villeneuve, Lionsgate, 2015.

Siembra. Directed by Ángela Osorio and Santiago Lozano, Contravía Films, 2016. El silencio de los fusiles. Directed by Natalia Orozco, RCN, 2017.

Simons, Geoff. Colombia: A Brutal History. SAQI, 2004.

Sin senos no hay paraíso. Directed by Miguel Varoni, Telemundo, 2008.

Sin tetas no hay paraíso. Directed by Gustavo Bolívar Moreno, Amazonas Films, 2010.

Sin tetas no hay paraíso. Directed by Luis Alberto Restrepo, Caracol TV, 2006.

La sirga. Directed by William Vega, Contravía, 2012.

Skinner, Jonathan. Writing the Dark Side of Travel. Berghahn Books, 2012.

Smith, Stephen. Cocaine Train: Tracing my Bloodline through Colombia. Little, Brown, and Company, 1999.

- The Land of Miracles: A Journey through Modern Cuba. Hachette, 1997.

- Underground London: Travel beneath City Streets. Hachette, 2004.

La sociedad del semáforo. Directed by Rubén Mendoza, DíaFragma, Fábrica de Películas, 2010.

La sombra del caminante. Directed by Ciro Guerra, Ciudad Lunar Productions, 2004.

Suárez, Juana. Sitios de contienda: producción cultural colombiana y el discurso de la violencia. Iberoamericana Vervuert, 2010.

Taussig, Michael. Beauty and the Beast. University of Chicago Press, 2012.

-. My Cocaine Museum. University of Chicago Press, 2004.

- Law in a Lawless Land: Diary of a "limpieza" in Colombia. New Press, 2003.

- Shamanism, Colonialism, and the Wild Man: A Study in Terror and Healing. University of Chicago Press, 1986.

Thomet, Jacques. Íngrid Betancourt: ¿historias del corazón o razón de estado? Translated by Mauricio Vargas and Dominique Rodríguez Dalvard. Planeta, 2006.

Thompson, Matthew. My Colombian Death: A Journey into the Heart of South America's Most Dangerous Country. Picador, 2008.

Thoumi, Francisco E. "Illegal Drugs in Colombia: From Illegal Economic Boom to Social Crisis." The Political Economy of the Drug Industry: Latin America and the International System. Edited by Menno Vellinga. University of Florida Press, 2004, pp. 70-84. DOI: 10.1177/000271620258200108.

La tierra y la sombra. Directed by César Augusto Acevedo, Burning Blue, 2015. Todorov, Tzvetan. Memory as a Remedy for Evil. Seagull Books, 2010.

Todos tus muertos. Directed by Carlos Moreno, 64A Films, 2011.

Torrado, Santiago. "Quebrantos, el luto colectivo de Colombia por sus seres asesinados." El País. 11 June 2019. elpais.com/internacional/2019/06/11/ colombia/1560211000_126427.html

Torres, Juan Carlos. Operación Jaque. Planeta, 2009.

Los tres caínes. Directed by Mauricio Cruz Carlos Gaviria, RCN, 2013.

The Two Escobars. Directed by Jeff Zimbalist and Michael Zimbalist, ESPN, 2010. 


\section{Bibliography}

Ulloa, Astrid, editor. Extractivismos y posconflicto en Colombia: retos para la paz territorial. Universidad Nacional de Colombia, 2016.

UNESCO. "Observatory of Killed Journalists." en.unesco.org/themes/safetyjournalists/observatory/country/223685

"Unfunny Money: The FARC's finances." The Economist. 14 April 2016.

Valencia Agudelo, León, et al. La minería en el posconflicto: un asunto de quilates. Zeta, 2017.

Vallejo, Fernando. El desbarrancadero. Alfaguara, 2001.

- La Rambla paralela. Alfaguara, 2002.

- El río del tiempo. Alfaguara, 1998. 1994. La virgen de los sicarios. Suma de Letras, 2001.

Van Djick, José. Mediated Memories in the Digital Age. Stanford University Press, 2007. DOI: 10.1177/1750698007083895.

Vargas, Alejo. "Autodefensas Gaitanistas de Colombia, una amenaza latente en Colombia." UN Periódico Digital. 9 October 2020. unperiodico.unal. edu.co/pages/detail/autodefensas-gaitanistas-de-colombia-una-amenazalatente-en-colombia/

Vargas Llosa, Mario. "Pecados de mi padre." El País. 30 de mayo 2010. www. elpais.com/articulo/opinion/Pecados/padre/elpepiopi/20100530elpepiopi_11/

Tes Vásquez, Juan Gabriel. Historia secreta de Costaguana. Alfaguara, 2007.

- Los informantes. Alfaguara, 2004.

. Las reputaciones. Alfaguara, 2013.

. El ruido de las cosas al caer. Alfaguara, 2011.

Velasco, Luz Adriana. "Megaproyecto de Bolívar Moreno se hizo realidad." El Tiempo. 1 September 2010. www.eltiempo.com/archivo/documento/ MAM-3860949

Vellinga, Menno, editor. The Political Economy of the Drug Industry: Latin America and the International System. University of Florida Press, 2004.

La vendedora de rosas. Directed by Víctor Gaviria, Producciones Filmamento, 1998.

Los viajes del viento. Directed by Ciro Guerra, Ciudad Lunar Producciones, 2009.

Viezzer, Moema. Si me permiten hablar ... Testimonio de Domitila, una mujer de las minas de Bolivia. 6th edition. Siglo Veintiuno, 1979.

"Vingt millions de dollar pour libérer Betancourt." Le Figaro. 8 July 2008. www.lefigaro.fr/international/2008/07/04/01003-20080704ARTFIG00425-millions-de-dollarspour-liberer-betancourt-.php

Violencia. Directed by Jorge Forero, Burning Blue, 2015.

La virgen de los sicarios. Directed by Barbet Schroeder, Vértigo, 2000.

El vuelco del cangrejo. Directed by Óscar Ruiz Navia, Contravía Films, 2009.

Wetherell, Margaret. Affect and Emotion: A New Social Science Understanding. SAGE, 2012. DOI: 10.4135/9781446250945.

Williams, Gareth. Infrapolitical Passages: Global Turmoil, Narco-Accumulation, and the Post-Sovereign State. Fordham University Press, 2020.

Yepes Muñoz, Rubén Darío. Afectando el conflicto: mediaciones de la guerra colombiana en el arte y el cine contemporáneo. Instituto Distrital de las Artes - Idartes, 2018.

Youngs, Tim. The Cambridge Introduction to Travel Writing. Cambridge University Press, 2013. DOI: 10.1017/CBO9780511843150. 
Yúdice, George. The Expediency of Culture. Duke University Press, 2003.

—. "La reconfiguración de políticas culturales y mercados culturales en los noventa y el siglo XXI en América Latina." Revista Iberoamericana, vol. 197, 2001, pp. 639-659. DOI: 10.5195/REVIBEROAMER.2001.5840.

Žižek, Slavoj. Violence: Six Sideways Reflections. Picador, 2008.

Zuleta, Hernando, editor. Economía y seguridad en el posconflicto. Universidad de los Andes, 2018. 


\section{Index}

Note: Page references for figures are in italics.

Abad Faciolince, Héctor 50, $51,119 \mathrm{n} 23$

affect: affect and haptic visuality 134, 152; affect and haptic visuality in La sombra del caminante (Guerra) 135-141; affect and haptic visuality in La tierra y la sombra (Acevedo) 141-146; affect and haptic visuality in Violencia (Forero) 147; affective and tactile visualities 128, 132-133; affectoriented approaches in cinema 17, 121; consumers' affective relations with violence $3,4,9$; mediated cultural production 134-135; reconciliation and communal affective relationships 132-136, 139-141, 152 Agarrando pueblo (Mayolo/Ospina) 127-128

Alfaguara 11, 12, 19n10, 19n11

Appadurai, Arjun 14, 20n13, 39, 45

Arendt, Hannah 8

Arrubla, Germán 22

AUC (Autodefensas Unidas de Colombia) 108, 109

audiences: affective relationship with violence $3,4,9$; for dirty realism 10; illusory proximity to marginal subjects $2,3-4,9,12$, $21,24,48,51$; a priori knowledge for travel narratives 92-93; tactile visuality tropes in cinema 121-122; see also affect

Autodefensas Gaitanistas de Colombia (AGC) 6, 160

Autodefensas Unidas de Colombia (AUC) 7, 50, 56n23, 93, 108, 159
Baker, Jennifer 152

Balderston, Daniel 27, 53n6

banana massacre 101, 106

Benavides, Hugo 50-51

Bernal, Álvaro 27

Betancourt, Ingrid: attempted escapes 62; captivity memoirs 4, 59, 60, 67, 87n13; decision to enter the guerrilla zone 58 ; film versions of the FARC hostages 72-73; future media appropriation of the Betancourt story 63, 76; global cultural appropriation of the story of 57-60, 66-67; kidnapping of 57-58; La ligne bleue 79; lawsuit against the government $58,60,73$; liberation of 58; media presence, post-release 59 , 60,72 ; as a member of the French political elite 58-59, 66; postrelease story 57-58; presidential campaign 58; prueba de supervivencia (proof of life) video 62; as a public figure in Colombia 60; relationship with Clara Rojas 57, 76; status as a "star hostage" 57, 60, 65, 67, 75; see also Ingrid de la jungle; No hay silencio/Even Silence Has an End (Betancourt); Operación E; Operación Jaque

Beverley, John 71

Beyond Bogotá (Leech) 113, 115-116

Bhabha, Homi 94

Blanton, Casey 94, 117, 117n3

Boat, The (Le): blend of dirty and magical realism 37 ; "Cartagena" 36-38; dispossessed 
characters 35; figure of the refugee 35-36, 39; "Hiroshima" 39; Medellín in 36-39; memory as a cultural commodity $35-36$; portrayal of criminality 39-40; "Tehran Calling" 39; translocality of Colombia in 38-39; trope of Colombia's violence 39

bodies: beauty and cosmetic surgery 47-48; healthy vs. decaying in La virgen de los sicarios (Vallejo) 30-31; narco-aesthetics $48,49,50$

Bolaño, Roberto 10

Bolívar Moreno, Gustavo: Sin tetas no hay paraíso $16,47-49,51,56 \mathrm{n} 25$

Bongco, Mila 86n9

Botero, Fernando: artworks featuring Pablo Escobar 4, 16, 21, 22; Death of Pablo Escobar 22-24, 23

Britto, Lina 46

Bruno, Giuliana 86n8, 122, 148

Caballero, Martín (Gustavo Rueda Díaz) 63

Campos, Minerva 153n6

capitalism: the culture industry and $19 \mathrm{n} 7$; excess consumption in 16, 25-26; narco-accumulation 25,46 ; wealth/poverty dialectic 10 ; see also neoliberalism

Castillejo-Cuéllar, Alejandro $89 \mathrm{n} 27,161$

Centro de Memoria, Paz y Reconciliación (CMPR) 80, 81

Centro Nacional de Memoria Histórica (CNMH): ;Basta ya! Colombia: memorias de guerra $y$ dignidad 6, 79-80, 83-85; location 80-81; publication and documentation program 84-85; reflections on the construction of memory 80

Cepeda, María Elena 15

Chao, Ramón 4; see also Train of Ice and Fire: Mano Negra in Colombia, The (Chao)

Cocaine Train: Tracing My Bloodline Through Colombia (Smith): as colonial writing 106; on the dark side of Colombia 104-105, 106-107; family history and 103-104; global audiences for 104; as a magical and reconstructive tour 98, 104-105
Coghlan, Nicholas 113, 114, 115, 116n2

Colombia: diaspora 6, 13, 14, 15, 47; drug trade 45-46; exiled population 28-29, 47, 49; as a failed state 5-9, 79; geopolitical role 13-14; as a "hostage nation" 57 ; internal displacement 6, 28, 49, 85, 9495, 103; marijuana production 45, 46,47 ; narco-geography of 45 ; pacification process 6,128 , 134, 146, 158; post-conflict Colombia 157-158, 160-161; railway system 97-98, 100, 103, 105, 106, 118n15; reductionist media portrayals 40 ; struggle and survival narratives of 3,24 , 37, 57, 59-60, 66; transnational identity 14-15; see also Medellín

Colombia's violence: in The Boat (Le) 39; in cinema 127-128, 131; commodification of in the global cultural market 2, 3-5, 7-8, 9, 11-12, 15; criminal violence 8,9 ; cultural reproduction of 1, 2, 10-13; during key historical events 5-6, 8; lawpreserving violence 8-9; link-chain approach to 7 ; pacification process 128-129; State violence 8, 9

colonial writing: the foreign "I/ eye" of 94-95, 97-98, 102; legacy of in travel narratives 96-97; travelogues 92

comic books $86 \mathrm{n} 4,86 \mathrm{n} 7$, 86n9, 87n10; see also Ingrid de la jungle

commodification: of coca and cocaine 24, 45-47; of Colombia's violence $3-5,9,11-12,15,161,165$; of crime 48; of cultural differences 12 ; of death 95; of dirty realism 24, 51; in the global cultural market 2 , 3-5, 7-8, 9, 11-12, 15; of Latin American literature 2-3; of memory 35, 59; of narco-stories 24; of Pablo Escobar's legacy 40, 41-42, 43-45; of reconciliation 134

condition, term 4 conflict: mediation of 134-135; and post-conflict in Colombia 157-158, 161-162; and reconciliation 136, 138-141

Cortázar, Julio 2

Couret, Nilo 133-134

culture see global culture industry 


\section{Index}

dark exoticism: as typical of Latin America 10-11, 21, 41-42, 70, 93; violence as 3 ; see also dirty realism dark tourism: of Colombia 4, 16-17; commodification of death 95 ; defined 95; of FARC 119n24; marketing 95 ; in opposition to mass tourism 95-96; see also dirty realism

Davis, Rocío 43

democracy: in Colombia 8; Escobar's election to Congress 8; narcopolitics and 8-9

dirty realism: in The Boat (Le) 37; in Colombian literature 10-11; commodification of in the global cultural market 24, 51; magical/ gritty dialectic in travelogues 91, 92, 101-103, 109-110, 112; novels 10 ; success of $9-10$

drug trade: association with violence 46; in Colombia 45-46; marijuana production 45,46 ; narco-geography 45; see also Escobar, Pablo; narco-soap operas; narco-stories

Dudley, Steven 113, 114, 115, 116n2

\section{El ruido de las cosas al caer}

(Vásquez): as a global narcostory $32-33$; intertextuality with magical realism 34; narrative structure 32-33; the narrator's memory 34-35; slaying of Escobar's hippos 33-34

El silencio de los fusiles (Orozco) 158

ELN (Ejército de Liberación nacional) $5,6,24,114,120 \mathrm{n} 25,160$

Entel, Nicolás, Pecados de mi padre 40, 42-44

Entourage (HBO): Medellín 40-42; overview of 40; pop-culture consumption of Escobar 26, $40,41-42$

Escobar, Andrés 55n19

Escobar, Pablo: cocaine trade 25, 45; commodification of the legacy of $40,41-42,43-45$; death of 22,23 , 24, 33, 99; Death of Pablo Escobar (Botero) 22-24, 23; election to Congress 8; in Entourage 40, 41-42; Hacienda Nápoles 33, 52n2; hippos 33-34; La Catedral 8-9, 95; legacy of in Pecados de mi padre $40,42-43,44$; as a modern-day
Robin Hood 22; in Narcos (Netflix) 40, 49-50; in narco-storytelling 24; pop-culture portrayals $40,41-42$; a priori exposure to cultural representations 93; visual representations of $21,22-24,40$

Escobar Henao, Juan Pablo 40, 42-43; see also Pecados de mi padre (Entel)

Even Silence Has an End see No hay silencio/Even Silence Has an End (Betancourt)

excess: and beauty 47-48; and cultural consumption 10,1516, 25-26, 47-49, 51; and Pablo Escobar 23-24; related to dépense 25, 33

Fanta, Andrea 52n3

FARC (Fuerzas Armadas

Revolucionarias de Colombia): dark tourism 119 n24; formation 5; Garry Leech's detention by 115, 116; in the global cultural market 24; hostages 57; kidnapping of Ingrid Betancourt 57; in My Colombian Death (Thompson) 108; ownership of the Betancourt story 64-66; Peace Accords 6, 157-158; in The Robber of Memories: A River Journey Through Colombia (Jacobs) 112; translation of Ingrid de la jungle 63-65

Feiling, Tom 17, 92, 113, $114-115,120 \mathrm{n} 25$

film: affect-oriented approaches 132-136; Agarrando pueblo (Mayolo/Ospina) 127-128; cultural diversity 131; El silencio de los fusiles (Orozco) 158; haptic images 121-125, 132, 134-135, 152; intercultural cinema 135 ; international film market 135-136; La negociación (Martínez) 158; La sirga (Vega) 122-127, 123, 126, 127; mediation of conflict 134-135; Monos (Landes) 132; national cinema 129-131; new geographies in 129, 131-132, 144; optical visuality $121,122,151$; Pájaros de verano 132, 155n15; pornomiseria genre 127-128, 131; Rosario Tijeras 37, 52n4, $53 \mathrm{n} 6,53 \mathrm{n} 7$; tactile visuality tropes 
121-122, 132; 2003 cinema law 129-131, 135, 146; Violencia (Forero) 122-125, 125, 135; violent Colombian films 4, 127-128, 131; visual occlusion 122-125, $145,152 \mathrm{n} 2$; visual techniques for representations of violence 122-127, 131, 151-152; see also La sombra del caminante (Guerra); La tierra y la sombra (Acevedo); Operación E

Foley, Malcolm 117n5, 117n6

Forero, Gustavo 55n17

Forero, Jorge 17, 122, 130-131, 132, 146-151, 155n15, 156n22

Franco, Jean 2

Franco, Jorge: bestsellers 21; dirty realism 10-11; Rosario Tijeras 10, 37, 52n4, 53n6, 53n7

Fuentes, Carlos 2

Galán, Luis Carlos 40, 42-44

García Márquez, Gabriel: Cien años de soledad 34, 53-54n11, 100-102, 110, 112, 114, 118n11, 119n21; criticism of 3; El amor en los tiempos del cólera 111; magical realism 2, 34; Michael Jacobs' encounter with 107; in The Train of Ice and Fire (Chao) 16, 92, 97-103

Garde-Hansen, Joanne 68

global culture industry: audience proximity via 3, 4; Colombian music 15; commodification of Colombia's violence 3-5, 9, 11$12,15,161,165$; consumers' affective relations with 4 ; for dirty realism 24, 51; excess consumption in 25-26; Latin America in 2-4, 9, 11-12, 13-15, 41-42; maquila system $11,12,19 \mathrm{n} 11,48,49$, $51,52 \mathrm{n} 4$; memoirs and the memory boom 16, 35, 59, 60, 66-67, 79; memory commodification 35,59 ; of the Mexican War on Drugs 4-5; narco-stories in 24-25, 32-33, 35; parallels with illicit drug trade 24-25, 45-46; post-conflict Colombia 161-162; proliferation of narco-stories in 24-25; promotion of "worthy causes" 60; Southby-North market dynamics 4 , 16, 42, 44-45; translocalities of Colombia 13-15, 38-39, 40, 51; transnational appropriation of cultural production 11-12, 13, 14; transnational methodological literary settings 27-28, 32

globalization: of cultural production 3-5; homogenization of 96 ; inequalities in Latin American 3, 4, 7-8; transnational production methods 11-12

Gómez Gutiérrez, Felipe 86n10, 154n12

Gómez Tovar, José Crisanto 77

Gonsalves, Marc, Out of Captivity $67,88 \mathrm{n} 18$

guerillas: ELN (Ejército de Liberación Nacional) 5, 6, 24, 114, 120n25, 160; left-wing guerrilla groups 5; a priori exposure to cultural representations 93; Short Walks from Bogotá (Feiling) 114-115; use of the drug trade 36; see also FARC (Fuerzas Armadas Revolucionarias de Colombia)

Guerra, Ciro 17, 122, 131, 132, 134, 136, 153n6, 155n16; see also La sombra del caminante (Guerra)

Gutiérrez, Pedro Juan 10

haptic visuality (haptic perception) 17 , 121-132, 134-152, 152n1, 153n2; see also affect

Herlinghaus, Hermann 3, 10, 18n5, 23, 25, 45-46, 48, 56n 23

Holland, Patrick 94, 95-96

Hoyos, Héctor 23, 25-26, 32, 34, 47

Huggan, Patrick 94, 95-96

human rights $1-3,6,9,13,115$, 153n4, 161, 162

Huyssen, Andreas 66, 72, 82, 83,89 n 26

identity: the foreign " $\mathrm{I} /$ eye" 2,16 , 91, 93-95, 97, 98, 113; paternal legacies 42-44; the self and the Other in travelogues 93-95; the wandering subject 94-95

Ingrid de la jungle: cover, FARC 65; cover, original 64; FARC's ownership of the Betancourt story 64-66; FARC's translation and distribution of 63-65; parallels with No bay silencio 61, 62; as a parodic version of the Betancourt story $61,62-63$ 
Jacobs, Michael see Robber of Memories: A River Journey Through Colombia, The (Jacobs)

Karim, Aisha 7

\section{La desazón suprema: retrato} incesante de Fernando Vallejo (Ospina) 28-30

La negociación (Martínez) 158

La sirga (Vega) 122-127, 123, 126,127

La sombra del caminante (Guerra): affect and haptic visuality $135-141$; conflict and reconciliation in 136 , 138-141; visual techniques for the representation of violence 122-125

La tierra y la sombra (Acevedo): affect and haptic visuality 135 , 141-146; conflict and reconciliation in 141, 142-143, 144; dust and ash imagery 141-142, 142, 143-144, 144, 146; environmental issues 145-146; visual techniques for the representation of violence 122-125, 124

La Violencia (Obregón) 146-147, 149-151

Lander, María Fernanda 45

Landes, Alejandro 132

Lara Bonilla, Rodrigo 19n10, $40,42-44$

Las voces del secuestro radio program $88 \mathrm{n} 19,151,156 \mathrm{n} 22$

Latin America: appropriation of in the global cultural market 2-4, 9, 11-12, 13-15, 41-42; the Boom years $2-3$; diaspora 14 ; impact of globalization 3, 4, 7-8; imperialera European travelers to 92; neoliberalism 25; official memory sites $80,81-82$; reductionist media portrayals 40

Lawrence, Bruce 7

Lazzara, Michael 82

Le, Nam 4, 26, 35-40; see also Boat, The (Le)

Leech, Garry 92, 113, 115-116, $120 \mathrm{n} 25,120 \mathrm{n} 26$

Lennon, John 117n5, 117n6

Lisle, Debbie 96-97

literature: narco-novelas 10, 45; novela de la tierra 69, 76; tradition of testimonio 59, 68, 70-71; see also narco-stories
Lobo, Gregory 18n4

Londoño Echeverri, Rodrigo

(Timochenko) 157

Los tres caines 48, 49-50, $56 \mathrm{n} 23,56 \mathrm{n} 25$

\section{Madonna 15}

magical realism: association with Latin America 2, 3; in The Boat (Le) 37; El ruido de las cosas al caer (Vásquez) 34; magical/gritty dialectic in travelogues 91, 92, 101-103, 109-110, 112; see also

García Márquez, Gabriel

Malagón, Camilo 146

Maluma 15

Mancuso, Salvatore 108, 109

Mano Negra 98-103, 117n9

marketing: of Colombia 128-129; of Colombian cinema and television 45, 49, 155n15; of Colombian music 15-16; of dark tourism in Colombia 95; of Latin America 3-4, 9, 13; of media 68, 72-73, 157-158; of memory 82-83; of peace 157-158; of travelogues 96, 104, 107, 113

Marks, Laura 4, 121-122, 132, 145, 152

Marroquín, Sebastián 43; see also Pecados de mi padre (Entel)

Martín-Barbero, Jesús 50, 56n25

Martínez, Juliana 18n6, 125, 126-127

Martínez, Margarita 158

Mayolo, Carlos 127-128

McKinney, Mark 86n4, 86n7

Medellín: in "Cartagena," (Le) 36-39; in El ruido de las cosas al caer (Vásquez) 34; within the global culture industry 13; in La virgen de los sicarios (Vallejo) 28; murals 22; in My Colombian Death (Thompson) 109

"Medellín” (song) 15

Medellín cartel 5

media: 24-hour news cycles 59; the global (re)construction of memory 68; international interest in the Betancourt story 57-58; Las voces del secuestro radio program $88 \mathrm{n} 19,151$; presentation of the Peace Accords 157-158, 159; processes of historical memory in No bay silencio 69, 72 
media memory: the ;Basta ya! report and 84; collective memory and 68 ; concept of 59 ; historical amnesia 72 ; official memory sites in relation to 82-83; and the public's access to historical knowledge 60, 68-69, 70-71, 78-79

memoirs: of the Betancourt story 4, 59,60 ; captivity memoirs $4,59,60$; El hijo de la selva (Gómez Tovar) 77, 88n 21; by FARC hostages 67-68; future appropriation of the Betancourt story 63, 76; memory boom in global cultural production $16,35,59,60,66-67,79$; and the tradition of testimonio 59, 68, 70-71; see also No hay silencio/Even Silence Has an End (Betancourt) memory: (re)construction of by mass media 68; Alzheimer's and the loss of 111,112 ; aural memories 34; collective 59, 60, $68,80-82$; commodification of for global consumption 35, 59; and displacement in Fernando Vallejo's novels 27-28, 29, 30; ethics of a literary exploration of 35-36; historical memory 34; mass media processes of historical memory 60, 68-69, 70-71, 78-79; national "bad memory" 83-84; official memory sites in Latin America 80, 81-82; reconstruction of national historical memory $77,78,80-82,111-112$; tactile visuality tropes in cinema 121-122; within temporal narratives 62 ; of trauma 82; the voices of the victims of violence 84-85; see also Centro Nacional de Memoria Histórica (CNMH); media memory; Robber of Memories: A River Journey Through Colombia, The (Jacobs)

Mendoza, Élmer 5, 10

Mendoza, Mario 10-11

Mexican War on Drugs 4-5, 91

Mollison, James 22

Monos (Landes) 132

Moreiras-Menor, Cristina 82

Movimiento Revolucionario del Pueblo (MPR) 6, 160

Muiscas 45, 46

My Colombian Death: A Journey Into the Heart of South America's Most Dangerous Country (Thompson): the darker side of Colombia in 107-108; encounters with guerillas and paramilitaries 108-109; magical/gritty dialectic 109-110; observer/observed views 108-109; perspectives of 'home' in 107, 108, 110-111; yagé experience 109-110

narco-accumulation, term 25

narco-capitalism, term 25

narco-cultura, term 21-22

narco-dramas: cross over into narcosoap operas 50; Los tres caínes 48, 49-50, 56n23, 56n25; Sin tetas no hay paraíso $16,47-49,51,56 \mathrm{n} 25$ narco-politics 8, 42-43

Narcos (Netflix) 40, 49-50

narco-soap operas: frameworks of transnationalities 45; La reina del sur (Pérez Reverte) 55n22; narco-dramas' lapses into 50; phenomenon of 47, 48; Sin tetas no hay paraíso $16,47-49,51,56 \mathrm{n} 25$

narco-stories: beauty and violence relationship 47-48; conjunction of memory and displacement 27-28; defined 21; of dirty realism 10-12; Entourage (HBO) 26, 40-42; excess consumption in 25-26; genre 45 ; global audiences for 21; in the international cultural market 24-25, 32-33, 35; narco-soap operas 4, 15; of Pablo Escobar 24; Pecados de mi padre 26, 40, 42-45; production of and parallels with the drug trade 24-25, 45-46; on screen 40; within the transnational economy 26 ; violence and memory 34; as world literature 32; see also Le, Nam; Vallejo, Fernando; Vásquez, Juan Gabriel

Neiger, Motti 68

neoliberalism: commodification of cultural differences 12 ; cruel modernity of 2 ; cultures of excess 10; dark tourism and 95, 116; global cultural production 12, 134; global inequality and 18n3; human rights within market conditions 9; impact on agriculture 126, 143, 146; in Latin America 25; marketing of peace 157-158; South-by-North market dynamics 4, 16, 42, 44-45; violence and 25 
No hay silencio/Even Silence Has an End (Betancourt): as historical memory $69,70-71,72$; and the memory boom $67-72$; narrative structure 62,69; as a novela de la tierra 69; parallels with Ingrid de la jungle 61, 62; spatial and temporal displacement 69-70; as testimonio 70-72

Obregón, Alejandro 146-147, 149

O’Bryen, Rory 7, 18-19n6, 33, 53n10, 154n12

Operación E: Crisanto Gómez in 77-78, 78; film versions of the FARC hostages 72 ; marketing 72-73; movie poster 75; narrative structure 76-78; use of memory and historical reconstruction 77,78

Operación Jaque: Betancourt/Rojas relationship 76; Betancourt's portrayal in 75-76; distribution of 73-74; film versions of the FARC hostages 72 ; marketing 72-73; portrayal of the undercover operation 74-75; TV series poster 74

Orozco, Hernando 22

Orozco, Natalia 158

Osorio, Óscar 48

Ospina, Luis 28-30, 127-128, $154 \mathrm{n} 12$

Ospina, María 84, 85-86n3, 89-90n 27, 131, 145, 155n17, 155n18

Palacios, Marco 55n15

Palaversich, Diana 45

paramilitaries: adaptability of 7; AUC (Autodefensas Unidas de Colombia) 7, 50, 56n23, 93, 108, 109, 159; law-preserving violence $8-9$; Los tres caines 48, 49-50; in My Colombian Death (Thompson) 108; a priori exposure to cultural representations 93; right-wing groups 6; Short Walks from Bogotá (Feiling) 114-115; use of the drug trade 36

Peace Accords 6-7, 17, 80, 86n8, 134, 157-160

Pecados de mi padre (Entel): commodification of Pablo Escobar's legacy 40, 41-42, 43-45; narco-politics and 43-44; overview of 42-43; paternal legacies 43-44

Pécaut, Daniel 7, 85-86n3

Peretti, Viviana 162, 164, 165n2

Pérez Reverte, Arturo 55n22

Pobutsky, Aldona 21-22, 40, 52n2, $52 \mathrm{n} 4,53 \mathrm{n} 10$

Podalsky, Laura 132-133, 134, 152n12, 154n13

Polit Dueñas, Gabriela 11, 13, 19n10, 45, 53n11, 54

Pratt, Mary Louise 92, 95

Proimágenes 129-131, 153n6

Quebrantos (Salcedo) 17, 161-165, 163,164

reconciliation: commodification of 134 ; communal affective relationships 132-136, 138-141, 152; in La sombra del caminante (Guerra) 136, 138-141; in La tierra y la sombra (Acevedo) 141, 142-143, 144; national film productions 134; in Pecados de mi padre (Entel) 42-45; through cinematic haptic visual techniques 122-127, 131, 133, 152; transitional justice system 158-160

Restrepo, Laura: Delirio 10-11, 52n3, 52n $5,53 \mathrm{n} 11$; narco-stories 4, $10-11,21$

Riaño, Pilar 85, 86n3, 89n23

Rincón Gille, Nicolás 119n22

Rivera, José Eustasio 69, 76

Robber of Memories: A River Journey Through Colombia, The (Jacobs): darker side of Colombia 112-113; and El amor en los tiempos del cólera 111; guerillas in 112; magical/gritty dialectic 112 ; personal vs. national memories 111-112; perspectives of 'home' in 107, 111, 112

Rocha, Carolina $154 \mathrm{n} 7$

Rodríguez, Ileana 8

Rodríguez Gacha, José Gonzalo 25

Rojas, Clara: Cautiva 67-68; kidnapping of 57; relationship with Ingrid Betancourt 57, 76; see also Operación E

Rosenberg, Fernando 9

Rueda, María Helena 7, 9, $18 \mathrm{n} 6,28,45$

Rueda Díaz, Gustavo (Martín Caballero) 63, 86n8 
Saddest Country, The (Coghlan) 113, 114-115, 116n2

Said, Edward 93

Salcedo, Doris 4, 17, 134, 161-165, 163, 164

Sánchez Gómez, Gonzalo 79

Santos, Juan Manuel 128, 157, 159,160

Sassen, Saskia 14

Schuster, Sven 82, 85-86n3

Scotto, Serge 61, 64; see also Ingrid de la jungle

Seix Barral 11, 19n10

Short Walks from Bogotá (Feiling) 113, 114-115, 119n19, 155n18

sicaresca fiction $19 \mathrm{n} 10$

Smith, Stephen see Cocaine Train: Tracing My Bloodline Through Colombia (Smith)

Suárez, Juana 7, 130

Taussig, Michael 16, 25-26, $36,46,47$

Thompson, Matthew see My Colombian Death: A Journey Into the Heart of South America's Most Dangerous Country (Thompson)

Timochenko (Rodrigo Londoño Echeverri) 157

Todorov, Tzvetan 82

Train of Ice and Fire: Mano Negra in Colombia, The (Chao): the foreign "I/ eye" of 98 ; as a magical and reconstructive tour 98-99, 100-101; magical/gritty dialectic 101-103; observer/observed views 99-100; Office of Human Desires 99-100; references to Cien años de soledad (Márquez) 100-102

travel narratives: advocacy for the Colombian people 113-115; authorship and subject positionality 91-92; Colombia's violence through 93; colonial writing 92; confirmation of preconceptions of Colombia 96-97, 98, 106-107; countertravelers narratives 95-96; as encounters with difference 97; the foreign "I/ eye" of 2, 91, 93-94, 97, 98, 113; within the global cultural market 95; as a hybrid genre 93; legacy of Empire 96-97; magical/gritty dialectic 91, 92, 101-103, 109-110, 112; market diversification 113-114; of the new Colombia 91, 92, 113-116; observer/observed views 99-100, 108-109, 113; a priori exposure to cultural representations 92-93; self-reflexivity and instability 94; Short Walks from Bogotá (Feiling) 113, 114; the wandering subject 94-95; see also Cocaine Train: Tracing My Bloodline Through Colombia (Smith); dark tourism; My Colombian Death: A Journey Into the Heart of South America's Most Dangerous Country (Thompson); Train of Ice and Fire: Mano Negra in Colombia, The (Chao)

Uribe, Álvaro 13, 61, 128, 159, 160 Uribe, María Victoria 85, 89n23

Vallejo, Fernando: as a best-selling author 26-27; as a displaced author 27; El desbarrancadero 30-31; El río del tiempo 27; La desazón suprema: retrato incesante de Fernando Vallejo (Ospina) 28-30; La Rambla paralela 31-32; La virgen de los sicarios 26, 28, 29, 32; memory in the novels of $27-28$, 29, 30; narco-stories 4, 10-11, 21

Van Djick, José 68, 85n3

Vásquez, Juan Gabriel 4, 10-11, 16, 21, 26-27, 32

Vega, William 17, 122, 132, $153 \mathrm{n} 6$ violence: beauty and cosmetic surgery 47; casual 2; commodification of in the global cultural market 3-4; consumers' affective relations with $3,4,9$; cruelty and 2; drug trade's association with 46; lawpreserving violence 8-9; link-chain approach to 7; Mexican cultural representations of 4-5; power/ violence relationship 8; see also Colombia's violence violences, term 7

Violencia (Forero): affect and haptic visuality 135, 147; aural visuality 147-151, 150; free-access streaming 146; movie poster 148 ; narrative triptych 147; visual techniques for the representation of violence 122-125, 125 
188 Index

Walking Ghosts (Dudley) 113, $115,116 \mathrm{n} 2$

War on Drugs 4-5, 36, 46, 55n15

Wetherell, Margaret 133, 151

Williams, Gareth 25

Yepes, Rubén 134, 137, 154n13, 154n14, 155n19, 156n21

Youngs, Tim 93

Yúdice, George 11-13, 19n11, 20n12, $28,52 \mathrm{n} 4$ 